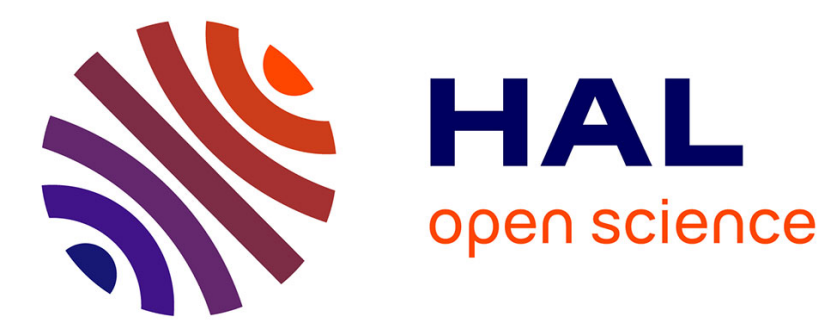

\title{
Environmental performance of feed additives in livestock supply chains. Guidelines for assessment Leap Fao
}

\section{To cite this version:}

Leap Fao. Environmental performance of feed additives in livestock supply chains. Guidelines for assessment. FAO. pp.ISBN: 978-92-5-132941-2, 2020, Livestock Environmental Assessment and Performance Partnership (FAO LEAP). hal-03227394

\section{HAL Id: hal-03227394 \\ https://hal.science/hal-03227394}

Submitted on 25 May 2021

HAL is a multi-disciplinary open access archive for the deposit and dissemination of scientific research documents, whether they are published or not. The documents may come from teaching and research institutions in France or abroad, or from public or private research centers.
L'archive ouverte pluridisciplinaire HAL, est destinée au dépôt et à la diffusion de documents scientifiques de niveau recherche, publiés ou non, émanant des établissements d'enseignement et de recherche français ou étrangers, des laboratoires publics ou privés. 
A Food and Agriculture Organization of the United Nations

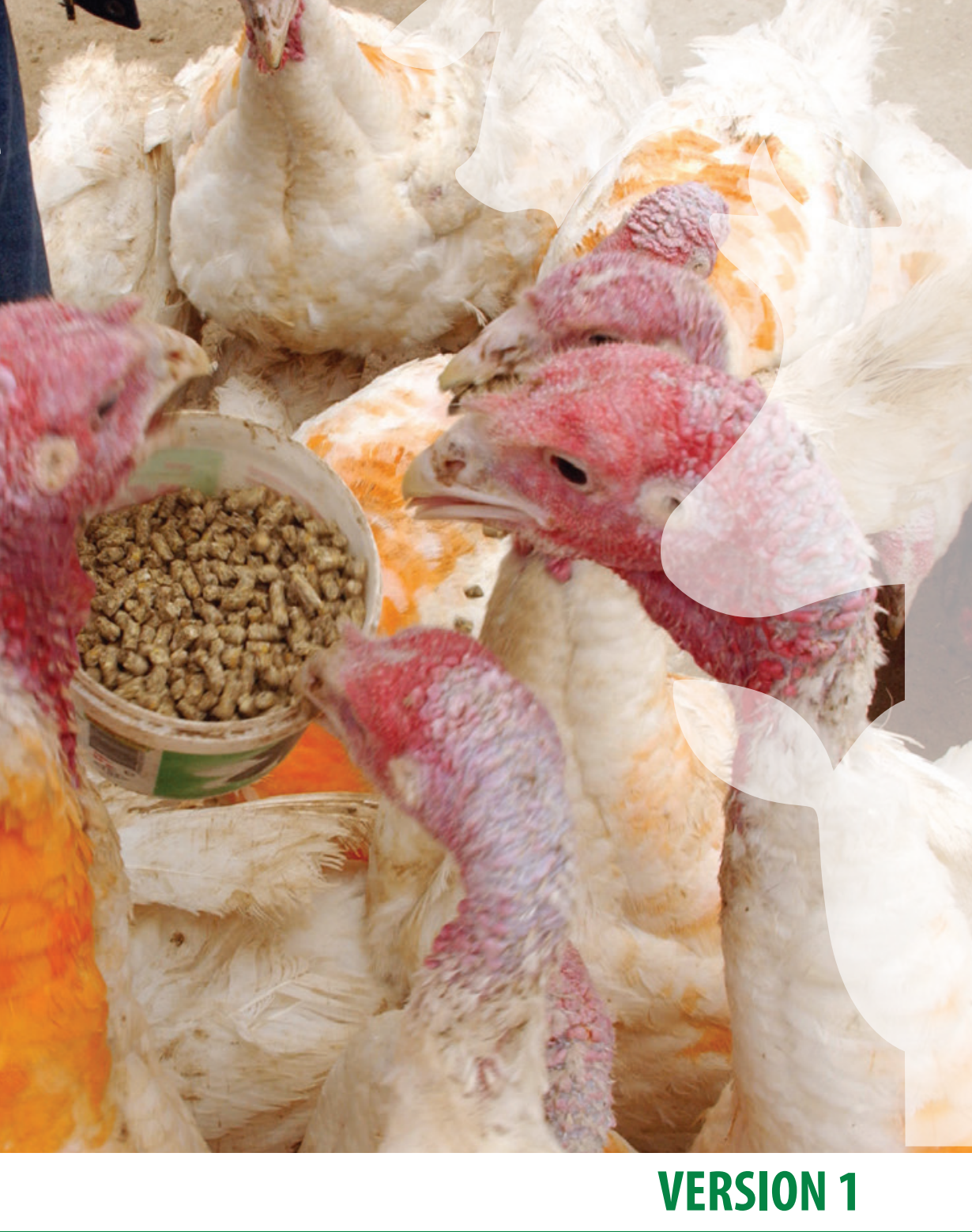

\section{Environmental performance of feed additives in livestock supply chains}

Guidelines for assessment 



\section{Environmental performance of feed additives in livestock supply chains}

Guidelines for assessment 


\section{Required citation:}

FAO. 2020. Environmental performance of feed additives in livestock supply chains - Guidelines for assessment Version 1. Livestock Environmental Assessment and Performance Partnership (FAO LEAP). Rome.

https://doi.org/10.4060/ca9744en

The designations employed and the presentation of material in this information product do not imply the expression of any opinion whatsoever on the part of the Food and Agriculture Organization of the United Nations (FAO) concerning the legal or development status of any country, territory, city or area or of its authorities, or concerning the delimitation of its frontiers or boundaries. The mention of specific companies or products of manufacturers, whether or not these have been patented, does not imply that these have been endorsed or recommended by FAO in preference to others of a similar nature that are not mentioned.

The views expressed in this information product are those of the author(s) and do not necessarily reflect the views or policies of FAO.

ISBN 978-92-5-132941-2

(C) FAO, 2020

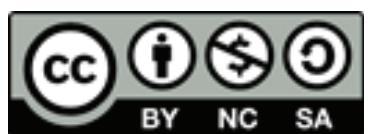

Some rights reserved. This work is made available under the Creative Commons Attribution-NonCommercial-ShareAlike 3.0 IGO licence (CC BY-NC-SA 3.0 IGO; https://creativecommons.org/licenses/by-nc-sa/3.0/igo/legalcode).

Under the terms of this licence, this work may be copied, redistributed and adapted for non-commercial purposes, provided that the work is appropriately cited. In any use of this work, there should be no suggestion that FAO endorses any specific organization, products or services. The use of the FAO logo is not permitted. If the work is adapted, then it must be licensed under the same or equivalent Creative Commons licence. If a translation of this work is created, it must include the following disclaimer along with the required citation: "This translation was not created by the Food and Agriculture Organization of the United Nations (FAO). FAO is not responsible for the content or accuracy of this translation.

The original [Language] edition shall be the authoritative edition."

Disputes arising under the licence that cannot be settled amicably will be resolved by mediation and arbitration as described in Article 8 of the licence except as otherwise provided herein. The applicable mediation rules will be the mediation rules of the World Intellectual Property Organization http://www.wipo.int/amc/en/mediation/rules and any arbitration will be conducted in accordance with the Arbitration Rules of the United Nations Commission on International Trade Law (UNCITRAL).

Third-party materials. Users wishing to reuse material from this work that is attributed to a third party, such as tables, figures or images, are responsible for determining whether permission is needed for that reuse and for obtaining permission from the copyright holder. The risk of claims resulting from infringement of any third-party-owned component in the work rests solely with the user.

Sales, rights and licensing. FAO information products are available on the FAO website (www.fao.org/publications) and can be purchased through publications-sales@fao.org. Requests for commercial use should be submitted via: www.fao.org/contact-us/licence-request. Queries regarding rights and licensing should be submitted to: copyright@fao.org. 


\section{Preparation of this document}

These guidelines are a product of the Livestock Environmental Assessment and Performance (LEAP) Partnership. The following groups contributed to their development.

\section{LEAP FEED ADDITIVES TECHNICAL ADVISORY GROUP}

The Technical Advisory Group (TAG) on feed additives conducted the background research and developed the core technical content. The feed additives TAG was composed of 26 experts: Ermias Kebreab (chair, University of California, Davis, United States of America), Chaouki Benchaar (co-chair, Agriculture and Agri-Food Canada), Philippe Becquet (Regulatory Strategy Adviser, France), Abdulrasak Ige Badina(University of Leeds, United Kingdom), Armin Towhidi (University of Tehran, Islamic Republic of Iran), Aurelie Wilfart (National Institute for Agricultural Research - INRA, France), Clandio Favarini Ruviaro (Federal University of Grande Dourados, Brazil), Colm Moran (Alltech, Ireland), Gunilla Eklund (Food and Agriculture Organization of the United Nations - FAO, Italy), Fafioulu Adeboye Olusesan (Federal University of Agriculture, Abekuta, Nigeria), Heinz Stichnothe (Institute of Agricultural Technology, Thünen Institute, Germany), Herve Juin (INRA, France), Ildiko Edit Tikasz (Research Institute of Agricultural Economics, Hungary), Joop de Knecht (National Institute for Public Health and the Environment, the Netherlands), José Velazco (National Institute of Agricultural Research, Uruguay), Laurence Shalloo (Agriculture and Food Development Authority - Teagasc, Ireland), Michael Binder (Evonik Nutrition \& Care GmbH, Germany), Mingjia Yan (University College Dublin, Ireland), Mojtaba Zaghari (University of Tehran, Islamic Republic of Iran), Nicolas Martin (Ajinomoto Animal Nutrition Europe, France), Patrick van Beelen (National Institute for Public Health and the Environment, the Netherlands), Rob Kinley (Commonwealth Scientific and Industrial Research Organisation - CSIRO, Australia), Vyas Diwakar (University of Florida, United States of America), Wang Liwen (Ministry of Agriculture and Rural Affairs, China), Jude Bond (Department of Primary Industries, New South Wales, Australia), and Yuan Yao (North Carolina State University, United States of America).

The feed additives TAG met in two workshops held on 26-28 February 2018 and on 4-6 July 2018 at the Food and Agriculture Organization of the United Nations (FAO), Rome, Italy. Between and after the workshops, the TAG worked via online communications and teleconferences.

\section{LEAP SECRETARIAT}

The LEAP Secretariat coordinated and facilitated the work of the TAG, guided and contributed to the content development and ensured coherence between the various guidelines. The LEAP Secretariat, hosted at FAO, was composed of: Camillo De Camillis (Technical officer and LEAP manager), Carolyn Opio (Technical officer and Coordinator), Aimable Uwizeye (Technical officer), Félix Teillard (Technical officer) and Maria Soledad Fernandez Gonzalez (Communication specialist). Camillo De Camillis and Aimable Uwizeye coordinated technical input to the LEAP TAG. 


\section{LEAP STEERING COMMITTEE}

The LEAP Steering Committee provided overall guidance for the activities of the Partnership and facilitated review and clearance of the guidelines for public release.

Steering Committee members: Douglas Brown (World Vision, until December 2016), Angeline Munzara (World Vision, since November 2016, South Africa), Richard de Mooij (European Livestock and Meat Trading Union - EUCBV; International Meat Secretariat - IMS), Matthew Hooper (Embassy of New Zealand, Italy, until 2018), Don Syme (Embassy of New Zealand, Italy, since May 2018), Alessandro Aduso (Ministry for Primary Industries, New Zealand, since 2018), Victoria Hatton (Ministry for Primary Industries, New Zealand, since January 2017), Peter Ettema (Ministry for Primary Industries, New Zealand), Hsin Huang (IMS, France, LEAP chair 2016), Gaelle Thyriou (Beef + Lamb New Zealand, IMS), Ben O’ Brien (Beef + Lamb New Zealand, IMS, from January to December 2017), JeanPierre Biber (International Union for Conservation of Nature - IUCN, Switzerland), María Sánchez Mainar (International Dairy Federation - IDF, Belgium, since January 2018), Caroline Emond (IDF, Belgium, since January 2018, LEAP chair 2019), Lionel Launois (Ministry of Agriculture, France), Pablo Manzano (IUCN, Kenya, LEAP chair 2017), Nicolas Martin (European Feed Manufacturers' Federation FEFAC, Belgium; International Feed Industry Federation - IFIF), Frank Mitloehner (University of California, Davis, IFIF, United States of America, LEAP chair 2013), Anne-Marie Neeteson-van Nieuwenhoven (International Poultry Council - IPC, the Netherlands, until May 2018), Peter Bradnock (IPC, since May 2018), Edwina Love (Department of Agriculture, Food and the Marine - DAFM, Ireland), Frank O’Mara (Agriculture and Food Development Authority - Teagasc, Ireland), Lara Sanfrancesco (IPC, Italy), Nicoló Cinotti (IPC, Italy, since May 2018), Marilia Rangel Campos (IPC, Brazil), Alexandra de Athayde (IFIF, Germany), Julian Madeley (International Egg Commission - IEC, United Kingdom), Dave Harrison (Beef + Lamb New Zealand, IMS, until December 2016), Paul McKiernan (DAFM, Ireland, until December 2016, LEAP co-chair 2015), Representatives of the International Planning Committee for World Food Sovereignty, Jurgen Preugschas (Canadian Pork Council, Canada, IMS), Nico van Belzen (IDF, Belgium, until December 2017), Elsbeth Visser (Ministry of Economic Affairs and Climate Policy - EZK, the Netherlands, from July 2015 to July 2016), Niek Schelling (EZK, the Netherlands, from July 2017 to July 2018), Henk Riphagen (EZK, the Netherlands, from July 2016 to July 2017), Kim van Seeters (Ministry of Agriculture, the Netherlands, since July 2018), Hans-Peter Zerfas (World Vision, until December 2017), Gianina Müller Pozzebon (Permanent Representative of Brazil to FAO, since March 2018), Felipe Heimburguer (Division of Basic Commodities, Ministry of Foreign Affairs, Brazil, since September 2017), Eric Robinson (Alternate Permanent Representative of Canada to FAO, until September 2017), Tim McAllister (Agriculture and Agri-Food Canada), Robin Mbae (State Department of Livestock, Kenya), Julius Mutua (State Department of Livestock, Kenya), Mauricio Chacón Navarro (Ministry of Agriculture and Livestock, Costa Rica), Fernando Ruy Gil (National Meat Institute - INAC, Uruguay, LEAP chair 2018), Walter Oyhantcabal (Ministry of Livestock, Agriculture and Fisheries, Uruguay), Francois Pythoud (Permanent Representative of Switzerland to FAO), Alwin Kopse (Swiss Federal Office for Agriculture - FOAG, Switzerland), Jeanine Volken (FOAG, Switzerland), Martin Braunschweig (Agroscope, Switzerland, until December 2017), Jennifer Fellows (Permanent Representative of Canada to FAO), 
Emmanuel Coste (Interbev, France, IMS), Beverley Henry (International Wool Textile Organisation - IWTO, Australia, from January 2016 to December 2017), Dalena White (IWTO, Belgium), Paul Swan (IWTO, Australia, since March 2018), Sandra Vijn (World Wild Fund for Nature - WWF, United States of America), Pablo Frere (World Alliance of Mobile Indigenous Peoples - WAMIP, Argentina), Henning Steinfeld (FAO, LEAP vice-chair), Carolyn Opio (FAO, LEAP Secretariat Coordinator since January 2015), and Camillo De Camillis (LEAP manager, FAO), Damien Kelly (Irish Embassy in Italy, until June 2018), Gary John Lanigan (Teagasc, Ireland), Paul McKiernan (DAFM, Ireland, until December 2016, LEAP co-chair 2015), Roberta Maria Lima Ferreira (Permanent Representative of Brazil to FAO, Italy, until October 2017), Renata Negrelly Nogueira (from October 2017 to March 2018), Delanie Kellon (IDF, until December 2017), Aimable Uwizeye (FAO), Félix Teillard (FAO), Juliana Lopes (FAO, until December 2017).

Observers: Margarita Vigneaux Roa (Permanent Representation of Chile to FAO), Zoltán Kálmán (Hungarian Embassy in Italy), István Dani (Ministry of Agriculture, Hungary, since December 2017), Officers of the Permanent Representation of Italy to the United Nations Organizations in Rome, Yaya Adisa Olaitan Olaniran (Embassy of Nigeria in Italy), Officers of the United States of America Embassy in Italy and of the United States Department of Agriculture (USDA), United States of America, Ian Thompson (Sustainable Agriculture, Fisheries and Forestry Division, Australia), Rosemary Navarrete (Sustainable Agriculture, Fisheries and Forestry Division, Australia), Mark Schipp (Department of Agriculture and Water Resources, Australia), María José Alonso Moya (Ministry of Agriculture, Food and Environment, Spain), Wang Jian (Department of Livestock Production, Ministry of Agriculture, China), Li Qian (Department of International Cooperation, Ministry of Agriculture, China), Tang Liyue (Permanent Representation of the People's Republic of China to the United Nations Agencies for Food and Agriculture in Rome), Nazareno Montani (Permanent Representation of Argentina to FAO), Margarita Vigneaux Roa (Embassy of Chile in Italy), Keith Ramsay (Department of Agriculture, Forestry and Fisheries, South Africa), Madan Mohan Sethi (Embassy of India in Italy), Lucia Castillo-Fernandez (European Commission, Directorate-General for International Cooperation and Development, Belgium), Rick Clayton (Health for Animals, Belgium), Eduardo Galo (Novus International), Coen Blomsma (European Union vegetable oil and protein meal industry association - FEDIOL, Belgium), Jean-Francois Soussana (National Institute for Agricultural Research - INRA, France), Fritz Schneider (Global Agenda for Sustainable Livestock - GASL), Eduardo Arce Diaz (GASL), Harry Clark (Global Research Alliance), Angelantonio D'Amario (European Livestock and Meat Trading Union - EUCBV, Belgium, IMS), Brenna Grant (Canadian Cattlemen's Association, IMS), Philippe Becquet (DSM, Switzerland, International Feed Industry Federation - IFIF), Maria Giulia De Castro (World Farmers' Organisation - WFO, Italy), Danila Curcio (International Cooperative Alliance, Italy), Matthias Finkbeiner (International Organization for Standardization-ISO; TU Berlin, Germany), Michele Galatola (European Commission, Directorate-General for Environment, Belgium), James Lomax (UN Environment), Llorenç Milà i Canals (Life Cycle Initiative, UN Environment), Paul Pearson (International Council of Tanners, ICT, United Kingdom), Primiano De Rosa (National Union of the Tanning Industry - UNIC, ICT, Italy), Christopher Cox (UN Environment), Gregorio Velasco Gil (FAO), James Lomax (UN Environment), Franck Berthe (World Bank), Patrik Bastiaensen (World 
Organisation for Animal Health - OIE), An de Schryver (European Commission, Directorate-General for Environment, Belgium), and Brian Lindsay (Global Dairy Agenda for Action), Judit Berényi-Üveges (Ministry of Agriculture, Hungary), Csaba Pesti (Research Institute of Agricultural Economics, Hungary), María José Alonso Moya (Ministry of Agriculture, Food and Environment, Spain), Pierre Gerber (World Bank), Rogier Schulte (Wageningen University, the Netherlands, LEAP co-chair 2015 on behalf of Ireland), Peter Saling (ISO, since February 2018; BASF), Erwan Saouter (European Food Sustainable Consumption and Production Round Table), Ana Freile Vasallo (Delegation of the European Union to the Holy See, Order of Malta, UN Organizations in Rome and to the Republic of San Marino, until September 2016).

\section{MULTI-STEP REVIEW PROCESS}

The initial draft guidelines developed by the TAG during 2018 underwent an internal review by the LEAP Secretariat and Steering Committee, and an external peer review before being revised and submitted for public review. Harinder Makkar (University of Hohenheim, Germany), Hans Blonk (Blonk Consultants, the Netherlands), Nathaniel Pellettier (University of British Columbia, Canada), Gregory Thoma (Arkansas University, United States of America) and John Kazer (Carbon Trust, United Kingdom) peer reviewed these guidelines.

Before being submitted for both external peer review and public review, the guidelines were reviewed by the LEAP Secretariat. The LEAP Steering Committee also reviewed them at various stages of their development and provided additional feedback before clearing and releasing them for public review.

The public review lasted from July to September 2019 and was advertised through the FAO website. Scholars in life cycle assessment (LCA) and environmental footprinting were informed through announcements circulated via the mailing list on LCA held by PRé Consultants. Livestock experts were reached through the Livestock Technical Network Newsletter. The following bodies were also reached for their input: Life Cycle Initiative; UN Environment; Livestock Research Group of the Global Research Alliance on Agricultural Greenhouse Gases (GRA); Global Agenda for Sustainable Livestock (GASL); Global Alliance for Climate-smart Agriculture (GACSA); Mitigation of Climate Change in Agriculture (MICCA) Project; Standing Committee on Agricultural Research (SCAR); Joint Programming Initiative on Agriculture Food Security and Climate Change (FACCE-JPI); European Commission's Environmental Footprint Technical Board members. Comments were also sought from relevant FAO technical units.

The following participated in the public review and hence contributed to improving the quality of this technical document: DSM Nutritional Products Ltd, Nicolas Martin (Ajinomoto Animal Nutrition Europe), Alberto Mantovani (National Institute of Health - ISS, Italy), JRC, European Commission, Bretscher Daniel (Agroscope, Switzerland), Deepashree Kand (Mootral SA, Switzerland) and Paul Welcher (United States Department of Agriculture).

\section{PERIOD OF VALIDITY}

These guidelines are to be periodically reviewed to ensure the validity of the information and methodologies on which they rely. At the time of development, no mechanism is in place to ensure such review. To obtain the latest version, the user is invited to visit the LEAP website (www.fao.org/partnerships/leap). 


\section{STRUCTURE OF THE DOCUMENT}

This document adopts the main structure of ISO 14040:2006 (ISO, 2006a) and the four main phases of the life cycle assessment (LCA): goal and scope definition, life cycle inventory (LCI) analysis, life cycle impact assessment (LCIA) and interpretation.

Part 1 presents a general overview.

Part 2 covers quantification of environmental impacts from production of feed additives.

Part 3 describes the quantification of the effect of feed additives on the environmental impacts of livestock systems, including goal and scope of the study, and life cycle inventory.

Part 4 provides guidance on the interpretation and summarizes the various requirements and best practices for reporting, including uncertainty analysis.

A glossary providing common terminology for practitioners is included. Additional information is presented in the appendices.

\section{PRESENTATIONAL CONVENTIONS}

These guidelines are explicit in indicating which requirements, recommendations, and permissible or allowable options users may choose to follow. The term "shall" is used to indicate what is required for an assessment to conform to these guidelines. The term "should" is used to indicate a recommendation, but not a requirement. The term "may" is used to indicate an option that is permissible or allowable. Commentary, explanations and general informative material (e.g. notes) are presented in footnotes and do not constitute a normative element. 



\section{Contents}

Foreword $\quad x i$

Acknowledgements xiii

Abbreviations and acronyms $\quad$ xvi

Background information on Livestock Environmental Assessment

and Performance Partnership and Technical Advisory Group on Feed Additives xvi

Summary xviii

PART 1

OVERVIEW AND GENERAL PRINCIPLES

1. OBJECTIVES AND INTENDED USERS

2. SCOPE

2.1 Environmental impact 5

2.2 Application 5

3. BACKGROUND INFORMATION AND PRINCIPLES 7

$3.1 \mathrm{Goal}$ and scope $\quad 7$

3.2 Environmental impact categories $\quad 7$

3.3 Normative references 8

3.4 Non-normative references 8

3.5 Guiding principles $\quad 10$

4. BACKGROUND INFORMATION ON FEED ADDITIVES 13

4.1 Manufacturing/production of feed additives 13

4.1.1 Product description 13

4.1.2 Description of the production processes 14

4.1.3 Modularity 20

4.2 Use of feed additives $\quad 23$

4.2.1 Feed composition $\quad 23$

4.2.2 Feed conversion efficiency 24

4.2.3 Reduction of feed losses $\quad 26$

4.2.4 Modification of environmental emissions 26

PART 2

METHODOLOGY FOR QUANTIFICATION OF ENVIRONMENTAL

IMPACTS FROM MANUFACTURING/PRODUCTION OF FEED ADDITIVES 29

5. GOAL AND SCOPE DEFINITION 31

$5.1 \mathrm{Goal}$

5.2 Scope 31

5.3 Functional units and reference flows 32

5.4 System boundary of feed additive production stage 32

5.5 Material contribution and threshold 32

5.6 Time boundary for data 33 
5.7 Life cycle inventory 33

5.7.1 Overview 33

5.7.2 Compiling and recording inventory data 34

5.7.3 Data quality assessment

\section{PART 3}

METHODOLOGY FOR QUANTIFICATION OF ENVIRONMENTAL

IMPACTS FROM USING FEED ADDITIVES

6. GOAL AND SCOPE DEFINITION

$6.1 \mathrm{Goal}$

6.2 Scope $\quad 41$

6.3 Functional units and reference flows $\quad 42$

6.4 System boundary of feed additive use stage $\quad 42$

6.5 Transport and trade $\quad 43$

6.5.1 Intermediate transport and trade 43

6.5.2 Relevant inputs, resource use and emissions during transport and trade 43

6.6 General model for deriving inventory data $\quad 45$

6.7 Criteria for system boundary 46

6.8 Material contribution and threshold $\quad 46$

6.9 Time boundary for data $\quad 46$

6.10 Life cycle inventory (diets including feed additives) 46

6.10.1 Overview 46

6.10.2 Compiling and recording inventory data $\quad 47$

6.10.3 Modelling effects of feed additives $\quad 47$

6.10.4 Comparison baseline scenario and feed additive scenario 52

6.11 Additional data quality considerations 88

PART 4

INTERPRETATION OF RESULTS

7. PRINCIPLES OF INTERPRETATION

7.1 Identification of key issues 93

7.2 Characterization of uncertainty 94

7.3 Recognition of limitations and recommendations 95

7.3.1 Monte Carlo analysis $\quad 95$

7.3.2 Sensitivity analysis $\quad 95$

7.3.3 Normalization $\quad 95$

$\begin{array}{ll}\text { REFERENCES } & 97\end{array}$

$\begin{array}{ll}\text { GLOSSARY } & 101\end{array}$

$\begin{array}{ll}\text { APPENDICES } & 107\end{array}$

APPENDIX 1: EXAMPLES OF APPLICATION OF FEED ADDITIVES

$\begin{array}{ll}\text { AND THEIR FUNCTIONS } & 109\end{array}$

$\begin{array}{ll}\text { APPENDIX 2: CASE STUDIES } & 119\end{array}$ 


\section{Foreword}

These guidelines are a product of the Livestock Environmental Assessment and Performance (LEAP) Partnership, a multi-stakeholder initiative whose goal is to improve the environmental sustainability of livestock supply chains through better methods, metrics and data.

The aim of the methodology developed in these guidelines is to introduce a harmonized international approach for assessing the environmental footprint of feed additives. The livestock sector is a major user of natural resources such as land, water and nutrients and contributes to both greenhouse gases and nutrient loss, the latter often resulting in water and air pollution. Increasing resource efficiency in livestock productions is key in order to alleviate competition for resources with others sectors, drastically curb emissions and prevent water pollution.

Many categories of feed additives exist worldwide and they can be used by all livestock producers. Manufactured by a wide range of sectors, feed additives target different livestock species to pursue different objectives ranging from improving nutrition and animal health, to curbing emissions and preventing pollution. Research is very active in this field and a growing number of additives are being conceptualized and developed, increasingly marketed as disruptive eco-innovation by industry.

As feed additives carry both environmental burdens from their production and environmental benefits from their usage, environmental assessments have often failed to address this complexity. These guidelines strive for a more coherent inclusion of feed additives in environmental assessments of livestock production, in order to increase the understanding of the environmental footprint of feed additives and to reveal possible synergies or trade-offs with other environmental criteria.

The specific objectives of these guidelines are:

- To develop a harmonized, science-based approach resting on a consensus among the sector's stakeholders;

- To recommend a scientific, but at the same time practical, approach that builds on existing or developing methodologies;

- To promote approaches for assessing the impact of feed additives at local to global scale, by various users and relevant to diverse livestock supply chains;

- To leave room for the adaptation of the methodology to specific applications, while providing a common framework to ensure a minimum level of harmonization as well as robustness and transparency.

During the development process, these guidelines passed both a technical review and public review. The purpose was to strengthen the advice provided and ensure that the technical document meets the needs of those seeking to improve the environmental footprint of livestock production through sound assessment practice. This document is not intended to remain static. It will be updated and improved as the sector evolves and more stakeholders become involved in LEAP, and as new methodological frameworks and data become available.

The guidelines developed by the LEAP Partnership gain strength because they represent a multi-actor-coordinated, cross-sectoral and international effort to 
harmonize assessment approaches. Ideally, the harmonization leads to greater understanding, transparent application and communication of metrics, and, not least, real and measurable improvement in environmental performance.

Pablo Frere, World Alliance of Mobile Indigenous Peoples (LEAP chair 2020)

Caroline Emond, International Dairy Federation (LEAP chair 2019)

Ruy Fernando Gil, Uruguay (LEAP chair 2018)

Pablo Manzano, International Union for Conservation of Nature (IUCN) (LEAP chair 2017)

Hsin Huang, International Meat Secretariat (IMS) (LEAP chair 2016)

Henning Steinfeld, Food and Agriculture Organization of the United Nations (FAO) (LEAP co-chair) 


\section{Acknowledgements}

FAO is very grateful for all valuable contributions provided at various levels by LEAP partners. Particular gratitude goes to the following countries that have continually supported the Partnership through funding and often in-kind contributions: France, Ireland, the Netherlands, New Zealand, Canada, Switzerland and Uruguay. Appreciation also goes to the French National Research Institute for Agriculture, Food and Environment (INRAe) for in-cash and in-kind contributions to the LEAP Partnership. Particularly appreciated were the in-kind contributions from the following civil society organizations and non-governmental organizations represented in the Steering Committee: the International Planning Committee for Food Sovereignty, the International Union for Conservation of Nature (IUCN), the World Alliance of Mobile Indigenous Peoples (WAMIP), World Vision and the World Wild Fund for Nature (WWF). The following international organizations and companies belonging to the LEAP private sector cluster also played a major role by actively supporting the project via funding and/or in-kind contributions: the International Dairy Federation (IDF), the International Egg Commission (IEC), the International Feed Industry Federation (IFIF), the International Meat Secretariat (IMS), the International Poultry Council (IPC), the International Council of Tanners (ICT), the International Wool Textile Organisation (IWTO), the European Union vegetable oil and protein meal industry association (FEDIOL), Health for Animals, the Global Feed LCA Institute (GFLI), DSM Nutritional Products AG and Novus International. Last but not least, the LEAP Partnership is also grateful for the advice provided by the International Organization for Standardization (ISO), UN Environment and the European Commission, is honoured to network with the Global Research Alliance, the Life Cycle Initiative, the Global Soil Partnership, the "4 per 1000" Initiative, the Global Alliance for Climate-smart Agriculture (GACSA), and to share achievements in the context of the Global Agenda for Sustainable Livestock.

\section{ADDITIONAL CONTRIBUTIONS}

Although not directly responsible for the preparation of these guidelines, the other TAGs of the LEAP Partnership indirectly contributed to the preparation of this technical document.

Professional editing and proofreading was done by Ruth Duffy. Enrico Masci and Claudia Ciarlantini (FAO) were responsible for figure design and for formatting and layout of this publication. Administration support was provided by Christine Ellefson (FAO). 


\title{
Abbreviations and acronyms
}

\author{
ADEME French Environment and Energy Management Agency \\ AFNOR French Standardization Association \\ AMR Antimicrobial resistance \\ AP Acidification potential \\ BSI British Standards Institution \\ CAC Codex Alimentarius Commission \\ DMI Dry matter intake \\ DQR Data quality rating \\ EF Emission factor \\ EP Eutrophication potential \\ EU European Union \\ FAO Food and Agriculture Organization of the United Nations \\ FEU Fossil energy use \\ GHG Greenhouse gas \\ GWP Global warming potential \\ IDF International Dairy Federation \\ IEA International Energy Agency \\ IFIF International Feed Industry Federation \\ ILCD International Reference Life Cycle Data System \\ IPCC Intergovernmental Panel on Climate Change \\ ISO International Organization for Standardization
}


LCA Life cycle assessment

LCI Life cycle inventory

LCIA Life cycle impact assessment

LEAP Livestock Environmental Assessment and Performance Partnership

LO Land occupation

LUC Land use change

PAS Publicly Available Specification

PCR Product Category Rules

PDF Probability density function

PEF Product Environmental Footprint

PEFCR Product Environmental Footprint Category Rules

SCP Sustainable Consumption and Production

TAG Technical Advisory Group

UNEP United Nations Environment Programme

WBCSD World Business Council for Sustainable Development

WHO World Health Organization

WRI World Resources Institute 


\section{Background information on Livestock Environmental Assessment and Performance Partnership and Technical Advisory Group on Feed Additives}

\section{LIVESTOCK ENVIRONMENTAL ASSESSMENT AND PERFORMANCE (LEAP) PARTNERSHIP}

LEAP is a multi-stakeholder initiative launched in July 2012 with the goal of improving the environmental performance of livestock supply chains. Hosted by the Food and Agriculture Organization of the United Nations (FAO), LEAP brings together the private sector, governments, academia, civil society representatives and leading experts who have a direct interest in the development of science-based, transparent and pragmatic guidance to measure and improve the environmental performance of livestock products. The first phase of the Partnership (2013-15) focused mainly on the development of guidelines to quantify the greenhouse gas (GHG) emissions, energy use and land occupation from feed and animal supply chains and to illustrate the principles for biodiversity assessment. The second phase (2016-18), known as LEAP+, broadened the scope, focusing on, for example, water footprinting, nutrient flows and impact assessment, soil carbon stock changes, quantification of the impact of livestock on biodiversity and the impact of feed additives. In the context of environmental challenges such as climate change and increasing competition for natural resources, the projected growth of the livestock sector in the coming decades places significant pressure on livestock stakeholders to adopt sustainable development practices. In addition, the identification and promotion of the contributions that the sector can make towards a more efficient use of resources and better environmental outcomes are also of great significance. Currently, many different methods are used to assess feed additives and their associated environmental impacts as well as the performance of livestock products when feed additives are used. This can result in confusion, making it difficult to compare results and set priorities for continuing improvement. With increasing demands in the marketplace for more sustainable products, there is also the risk that debates about how sustainability is measured will distract people from the task of making real improvements in environmental performance. There is the added danger that either labelling or private standards based on poorly developed metrics could lead to erroneous claims and comparisons. The Partnership addresses the urgent need for a coordinated approach to develop clear guidelines for environmental performance assessment based on international best practices. The scope of LEAP is not to propose new standards but to produce detailed guidelines that are specifically relevant to the livestock sector and to refine guidance concerning existing standards. The three groups comprising the Partnership have an equal say in deciding work 
plans and approving outputs from LEAP, thus ensuring that the guidelines produced are relevant to all stakeholders, widely accepted and supported by scientific evidence. The work of LEAP is challenging yet vitally important to the livestock sector. The diversity and complexity of livestock farming systems, products, stakeholders and environmental impacts can only be matched by the willingness of the sector's practitioners to work together to improve performance. LEAP provides the essential backbone of robust measurement methods to enable assessment, understanding and improvement in practice. ${ }^{1}$

\section{TECHNICAL ADVISORY GROUP ON FEED ADDITIVES}

The feed additives Technical Advisory Group (TAG) of the Partnership was formed in November 2017. The core group comprised 26 experts in animal sciences, crop sciences, soil sciences, life cycle assessment, environmental science and livestock production systems. Their backgrounds, complementary between systems and regions, allowed them to understand and address different perspectives. The TAG was led by Ermias Kebreab (University of California, Davis, United States of America) and Chaouki Benchaar (Agriculture and Agri-Food Canada, Canada), assisted by Camillo De Camillis and Aimable Uwizeye from the LEAP Secretariat. The role of the TAG was to develop technical guidelines concerning the environmental impacts associated with the production of feed additives; and the effects of the use of feed additives on the environmental impacts of livestock systems.

The TAG met in two workshops held at FAO, Rome, Italy: the first from 26 to 28 February 2018 and the second from 4 to 6 July 2018. Between the workshops, the TAG worked via online communications and teleconferences.

\footnotetext{
More background information on the Partnership can be found at: www.fao.org/partnerships/leap/en/.
} 


\section{Summary}

The methodology developed in these guidelines aims to introduce a harmonized international approach to the assessment of the environmental performance of feed additives in livestock supply chains taking into consideration the impact of their production and use all along the supply chain for large ruminants, pigs and poultry. It aims to increase understanding of feed additives and to improve assessment of their environmental performance. The guidelines are a product of the Livestock Environmental Assessment and Performance (LEAP) Partnership, a multi-stakeholder initiative whose goal is to improve the environmental sustainability of the livestock sector through better methods, metrics and data. The guidelines on the environmental performance of feed additives in livestock supply chains are intended to be used with other published LEAP guidelines such as those on the environmental performance of large ruminant supply chains (FAO, 2016b). The table summarizes the major recommendations of the feed additives Technical Advisory Group for performance of life cycle assessment (LCA) to evaluate the environmental performance of feed additives in livestock supply chains. It is intended to provide a condensed overview and information on the location of specific guidance within the document. In addition, as a general rule, assessments and guidelines claiming to be aligned with the present LEAP guidelines should flag and justify with reasoning any deviations. 


\begin{tabular}{llc} 
Topic & Summary recommendation & Section \\
DEFINITION OF THE PRODUCT GROUP & 4 \\
\hline $\begin{array}{l}\text { Manufacturing of } \\
\text { feed additives }\end{array}$ & $\begin{array}{l}\text { A feed additive is a component, part or constituent of any } \\
\text { combination or mixture making up a feed, whether or not it } \\
\text { has nutritional value in the animal's diet. }\end{array}$ & 4.1 \\
\hline $\begin{array}{l}\text { Use of feed } \\
\text { additives }\end{array}$ & $\begin{array}{l}\text { Feed additives may influence feed composition, feed conver- } \\
\text { sion efficiency, reduction of feed losses and mitigation of envi- } \\
\text { ronmental emissions. }\end{array}$ & 4.2 \\
\hline GOAL AND SCOPE DEFINITION FROM MANUFACTURING FEED ADDITIVES \\
\hline Goal of the LCA & $\begin{array}{l}\text { The goal shall define: the subject, purpose, intended use and } \\
\text { audience, limitations, whether internal or external critical re- } \\
\text { view is required, and the study commissioner. }\end{array}$ & 5.1 \\
\hline Scope of the LCA & $\begin{array}{l}\text { The scope shall define: the process and functions of the sys- } \\
\text { tem, the functional unit and system boundaries, allocation } \\
\text { principles and impact categories. }\end{array}$ & 5.2 \\
\hline $\begin{array}{l}\text { Functional unit and } \\
\text { reference flows }\end{array}$ & $\begin{array}{l}\text { 1 kg of the final product leaving the manufacturing plant and } \\
\text { packaged for shipping to the point of consumption. }\end{array}$ & 5.3 \\
\hline $\begin{array}{l}\text { Description of } \\
\text { system boundary }\end{array}$ & $\begin{array}{l}\text { The system boundaries for studies of feed additives are a combi- } \\
\text { nation of boundaries of the different existing guidelines (on feed } \\
\text { production, feed additive production and livestock) linked to the } \\
\text { production of feed containing additives and its uses along the } \\
\text { feed chain and on the farm (from cradle to farm gate). }\end{array}$ & \\
\hline $\begin{array}{l}\text { Time boundary of } \\
\text { data }\end{array}$ & $\begin{array}{l}\text { Flows contributing less than 1\% to impacts may be cut off, } \\
\text { provided that 95\% of each impact category is accounted, based } \\
\text { on a scoping analysis. }\end{array}$ & 5.5 \\
\hline $\begin{array}{l}\text { For products derived from industrial processes (e.g. fermenta- } \\
\text { tion, extraction, chemical conversion), annually averaged data } \\
\text { should be used. For other processes (e.g. algae or plant pro- } \\
\text { duction), at least the length of one or more production cycles }\end{array}$ & \\
\hline should be used. & 5.6 \\
\hline
\end{tabular}

GOAL AND SCOPE DEFINITION FROM USE OF FEED ADDITIVES

Goal of the LCA The goal of the study is principally to evaluate the effect of using feed additive(s) on the environmental footprint (e.g. carbon footprint, eutrophication, acidification) of animal products (e.g. milk, meat, eggs), considering the impact of the manufacturing of the feed additive and on-farm emissions linked to its use.

Scope of the LCA The scope shall define: the process and functions of the system, the functional unit and system boundaries, allocation principles and impact categories.

Functional unit and $1 \mathrm{~kg}$ of live weight for meat-producing animals; $1 \mathrm{~kg}$ of energyreference flows corrected milk; $1 \mathrm{~kg}$ of egg in shell; 1000 chicks produced; $1 \mathrm{~kg}$ of greasy wool or based on goal and scope. 


\begin{tabular}{|c|c|c|}
\hline $\begin{array}{l}\text { Description of } \\
\text { system boundary }\end{array}$ & $\begin{array}{l}\text { The system boundaries of this guideline are a combination of } \\
\text { the boundaries of the different existing guidelines (feed pro- } \\
\text { duction, livestock-related guidelines) and make the link to } \\
\text { the production of feed additives and their uses along the feed } \\
\text { chain and on the farm. }\end{array}$ & 6.4 \\
\hline Transport and trade & & 6.5 \\
\hline $\begin{array}{l}\text { Intermediate } \\
\text { transport and trade }\end{array}$ & $\begin{array}{l}\text { Transport and the related storage are intermediate steps within } \\
\text { the feed production stages. The upstream and downstream } \\
\text { system boundaries depend on the respective stages, which are } \\
\text { given in detail in subsection } 8.4 .6 \text { of the LEAP guidelines on } \\
\text { animal feeds supply chains. }\end{array}$ & 6.5 .1 \\
\hline $\begin{array}{l}\text { Relevant inputs, } \\
\text { resource use and } \\
\text { emissions }\end{array}$ & $\begin{array}{l}\text { The type of product, transport distance and mode, storage } \\
\text { loss, and ancillary energy requirements for storage (e.g. refrig- } \\
\text { eration or ventilation) shall be included in the inventory. }\end{array}$ & 6.5 .2 \\
\hline $\begin{array}{l}\text { Criteria for system } \\
\text { boundary }\end{array}$ & $\begin{array}{l}\text { A flow diagram of all assessed processes should be drawn that } \\
\text { indicates where processes were cut off. For the main transfor- } \\
\text { mation steps within the system boundary, it is recommended } \\
\text { that a material flow diagram is produced and used to account } \\
\text { for all of the material flows. }\end{array}$ & 6.7 \\
\hline $\begin{array}{l}\text { Material } \\
\text { contribution and } \\
\text { threshold }\end{array}$ & $\begin{array}{l}\text { Flows contributing less than } 1 \% \text { to impacts may be cut off, } \\
\text { provided that } 95 \% \text { of each impact category is accounted, based } \\
\text { on a scoping analysis. }\end{array}$ & $5.5,6.8$ \\
\hline $\begin{array}{l}\text { Time boundary of } \\
\text { data }\end{array}$ & $\begin{array}{l}\text { The study shall use a population, technology mix, geography } \\
\text { and time period consistent with provision of the functional } \\
\text { unit (e.g. broiler chicken, about } 5 \text { weeks). }\end{array}$ & $5.6,6.9$ \\
\hline \multicolumn{2}{|c|}{$\begin{array}{l}\text { LIFE CYCLE INVENTORY FROM MANUFACTURING OF FEED } \\
\text { ADDITIVES }\end{array}$} & 5.7 \\
\hline Overview & $\begin{array}{l}\text { Inventory should be aligned with the goal and scope, and } \\
\text { shall include all resources use and emissions within the de- } \\
\text { fined system boundaries that are relevant to the chosen im- } \\
\text { pact categories and shall support the attribution of emissions } \\
\text { and resources use to single production units and co-products. } \\
\text { Primary data are preferred, where possible. Data sources and } \\
\text { quality shall be documented. }\end{array}$ & 5.7.1 \\
\hline $\begin{array}{l}\text { Compiling and } \\
\text { recording inventory } \\
\text { data }\end{array}$ & $\begin{array}{l}\text { In general, an inventory of all materials, energy resource inputs } \\
\text { and outputs, including products, co-products and emissions, } \\
\text { for the product supply chain under study shall be compiled. }\end{array}$ & 5.7 .2 \\
\hline $\begin{array}{l}\text { Data quality } \\
\text { assessment }\end{array}$ & $\begin{array}{l}\text { LCI data quality assessment shall address representative- } \\
\text { ness, completeness, consistency, precision/uncertainty, and } \\
\text { methodological appropriateness. }\end{array}$ & 5.7 .3 \\
\hline
\end{tabular}




\begin{tabular}{|c|c|c|}
\hline LIFE CYCLE INVH & NTORY FROM USE OF FEED ADDITIVES & 6.10 \\
\hline Overview & $\begin{array}{l}\text { Main components of a system boundary for producing } \\
1 \text { tonne of animal live weight include production of base feed } \\
\text { ingredients, production of feed additives, preparation of feed, } \\
\text { animal husbandry and manure management. The analysis shall } \\
\text { consider all "upstream" activities from the extraction of raw } \\
\text { materials to the manufacturing of basic intermediate products, } \\
\text { including transportation. }\end{array}$ & 6.10 .1 \\
\hline $\begin{array}{l}\text { Compiling and } \\
\text { recording inventory } \\
\text { data }\end{array}$ & $\begin{array}{l}\text { In general, an inventory of all materials, energy resource inputs } \\
\text { and outputs, including products, co-products and emissions, } \\
\text { for the product supply chain under study shall be compiled. }\end{array}$ & 6.10 .2 \\
\hline $\begin{array}{l}\text { Modelling effects of } \\
\text { feed additives }\end{array}$ & $\begin{array}{l}\text { When a feed additive changes feed composition, the baseline } \\
\text { scenario should be recalculated by introducing a variation fac- } \\
\text { tor linked to the use of the additive. To model the change in } \\
\text { emissions linked to the change in feed efficiency, the ratio be- } \\
\text { tween the baseline scenario and the scenario with the feed ad- } \\
\text { ditive is calculated. For a feed additive affecting gaseous emis- } \\
\text { sions, the ratio between the baseline scenario and the scenario } \\
\text { with the feed additive is calculated, using the variation in the } \\
\text { parameter linked to the use of the additive. }\end{array}$ & 6.10 .3 \\
\hline $\begin{array}{l}\text { Comparison } \\
\text { between baseline } \\
\text { scenario and feed } \\
\text { additive scenario }\end{array}$ & $\begin{array}{l}\text { Equations for the evaluation of the environmental impact of } \\
\text { livestock are based on other relevant LEAP guidelines. The } \\
\text { baseline scenarios are the comparison point for the feed addi- } \\
\text { tive scenario. }\end{array}$ & 6.10 .4 \\
\hline $\begin{array}{l}\text { Additional } \\
\text { data quality } \\
\text { considerations }\end{array}$ & $\begin{array}{l}\text { The effects of the additive on the nutrient level of the feed, } \\
\text { on the feed efficiency or the emission factors should be doc- } \\
\text { umented by robust state-of-the-art studies. A minimum of } \\
\text { three studies could be considered suitable. }\end{array}$ & 6.11 \\
\hline INTERPRETATIO & N OF LIFE CYCLE ASSESSMENT RESULTS & 7 \\
\hline $\begin{array}{l}\text { Identification of } \\
\text { key issues }\end{array}$ & $\begin{array}{l}\text { Thepractitioner shallevaluate the completeness (with respect to the } \\
\text { goal and scope); shall perform sensitivity checks (methodological } \\
\text { choices); and consistency checks (methodological choices, data } \\
\text { quality assessment and impact assessment steps). }\end{array}$ & 7.1 \\
\hline $\begin{array}{l}\text { Characterization of } \\
\text { uncertainty }\end{array}$ & $\begin{array}{l}\text { Data uncertainty should be estimated and reported through } \\
\text { formal quantitative analysis or by qualitative discussion, de- } \\
\text { pending on the goal and scope. }\end{array}$ & 7.2 \\
\hline
\end{tabular}



PART 1

Overview and general principles 



\section{Objectives and intended users}

The methodology and guidance developed here can be used by stakeholders in all countries and across the entire range of livestock production systems. In developing the guidelines, it was assumed that the primary users will be individuals or organizations with a good working knowledge of life cycle assessment (LCA). The main purpose of the guidelines is to provide a sufficient definition of calculation methods and data requirements on quality and transparency to enable consistent application of LCA across differing livestock supply chains. The guidelines allow for comparison of scenarios with and without specific feed additives and combinations thereof, supporting the evaluation of their effect in the given situation. These guidelines further support the applicant in communicating the final aggregated results of the LCA.

These guidelines are relevant to a wide range of livestock stakeholders including:

- livestock producers, advisors, civil associations and extension agents who wish to develop inventories of on-farm resources and assess the performance of production systems with or without specific feed additives or combinations thereof;

- supply chain partners (e.g. feed additive manufacturers, feed producers, farmers) seeking a better understanding of the environmental performance of products in their production processes;

- policymakers interested in developing accounting and reporting specifications for livestock supply chains or in designing agricultural policies including approval of use of feed additives for specific purposes; and

- researchers and scientists interested in understanding the potential environmental impact of new feed additives or relevant technologies under development.

The benefits of this approach include:

- use of a recognized, robust and transparent methodology developed to take account of the functions of feed additives and the nature of livestock supply chains;

- identification of supply chain hotspots and opportunities to improve and reduce environmental impact;

- estimation of efficiency and productivity changes;

- provision of support for reporting and communication requirements; and

- awareness raising and supporting action on environmental sustainability.

The objective of these guidelines is twofold:

- Provide detailed guidance on how to measure the environmental performance of the production of feed additives. Feed additives are feed ingredients and the recommendations and principles defined in the LEAP guidelines on feed supply chains also apply to feed additives. However, the LEAP guidelines on feed supply chains do not provide detailed recommendations on how to address the specificity of the production of feed additives, which differ significantly from other feed ingredients, including agricultural products. These guidelines aim to close this gap. 
- Provide detailed guidance on how to measure the effects of feed additives on the environmental performance of livestock products. The effect of feed additives on the environmental performance of animal products is not included in the different LEAP guidelines on animal supply chains published to date. These guidelines aim to close this gap.

These two objectives can be considered as modules when performing an LCA of animal products; different stakeholders can take care of different modules. In a study assessing the effect of feed additives on the environmental impact of livestock systems, the impact of the production of the feed additives shall be included. 


\section{Scope}

\subsection{ENVIRONMENTAL IMPACT}

The production and the use of feed additives influence the environmental impact of livestock production. The use of feed additives significantly acts on feed efficiency, and thus animal and environmental performance (nitrogen and phosphorus flows). With respect to the LEAP guidelines on feed supply chains (FAO, 2016a) and environmental quantification of nutrient flows (FAO, 2018a), the most relevant impact categories are global warming potential (GWP), eutrophication potential (EP), acidification potential (AP), land occupation (LO) and fossil energy use (FEU). Therefore, these feed additive guidelines cover the following environmental impact categories: climate change, fossil energy use, acidification and eutrophication.

These guidelines shall be used with other guidance developed by the Partnership, such as the LEAP guidelines on biodiversity (FAO, 2020). Other impact categories such as ecotoxicity may be applicable. In such cases, users need to collect and analyse additional information on feed additive production and use. This document does not provide support for the assessment of comprehensive environmental performance nor of the social or economic aspects of feed additive supply chains. It is intended to update these guidelines in the future to include multiple categories if enough reliable data become available to justify the changes.

Antimicrobial use is beyond the scope of these guidelines. Antimicrobials are not addressed herein, since the current state of knowledge does not permit quantification of the development of antimicrobial resistance (AMR) caused by the use of antimicrobials. Antibiotic resistance is a subset of the broader concept of AMR. While AMR can occur naturally, its development and spread are exacerbated by inappropriate use of antimicrobials. There is growing concern and evidence that some commonly used additives (e.g. copper) may co-select for antibiotic resistance in bacteria exposed to them (Medardus et al., 2014; Fang et al., 2016). On the other hand, it is recognized that adequate nutrition, including the use of feed additives, provides solutions to reduce the use of antimicrobials in livestock production systems. Veterinary medicines intended to be used for therapeutic purposes are beyond the scope of these guidelines and not addressed herein, as these guidelines focus on the effects of the use of feed additives on the environmental impacts of livestock production systems.

\subsection{APPLICATION}

These guidelines can be applied to various livestock production systems including large and small ruminants, poultry and pig production systems. These guidelines shall be read in conjunction with the LEAP species-specific and feed guidelines (Figure 1).

Some flexibility in methodology is desirable to accommodate the range of possible goals and special conditions arising in different sectors. This document strives for a pragmatic balance between flexibility and rigorous consistency across the scales, geographic locations and project goals. These guidelines can be used as a building block for more sophisticated methodologies for environmental footprinting 


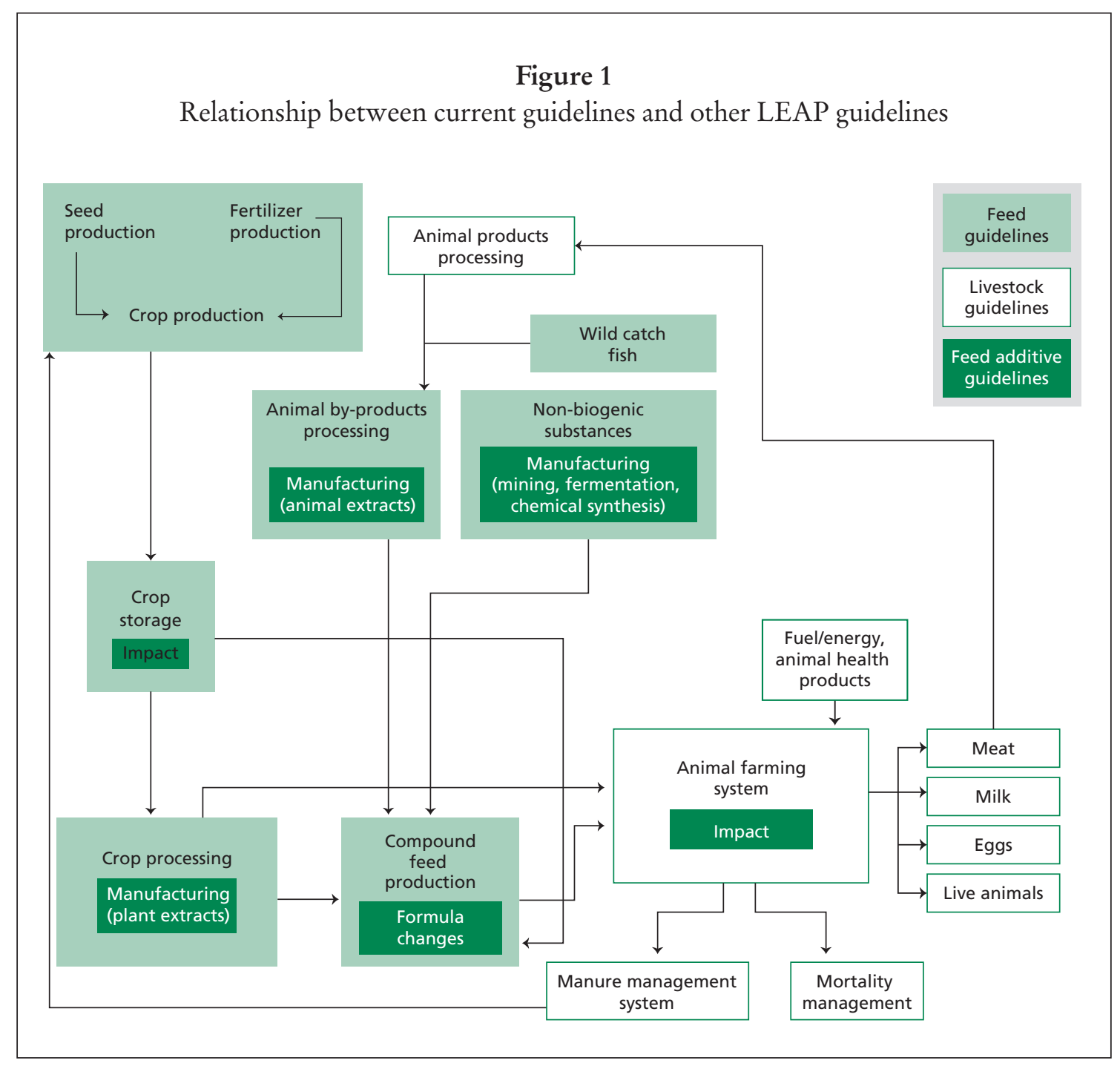

and environmental claims. Users are referred to ISO 14025:2006 for more information and guidance on comparative claims of environmental performance (ISO, 2006c).

These LEAP guidelines are based on the attributional approach to life cycle accounting. The approach refers to process-based modelling, intended to provide a static representation of average conditions. Due to the limited number of environmental impact categories covered here, results should be presented in conjunction with other environmental metrics to understand the wider environmental implications, whether positive or negative. It should be noted that comparisons between final products should only be based on a full LCA of animal products. Users of these guidelines shall not employ results to claim overall environmental superiority or to communicate overall environmental superiority of feed additives. The methodology and guidance developed in the Partnership is not intended to create barriers to trade or contradict any World Trade Organization requirements. 


\section{Background information and principles}

\subsection{GOAL AND SCOPE}

Life cycle assessment (LCA) is an established methodology used to quantify the environmental performance of products, processes or services, and is increasingly being used as a basis for information for purchasers along the supply chain, including final consumers (Fava et al., eds, 2011). LCA addresses the environmental aspects and potential environmental impacts, such as the use of resources and the environmental consequences of releases throughout a product's life cycle from raw material acquisition through production, use, end-of-life treatment, recycling and final disposal. There are four phases in an LCA study:

- Definition of the scope, including the system boundary and level of detail of an LCA, depends on the subject and the intended use of the study.

- Life cycle inventory (LCI) analysis entails an inventory of input/output data with regard to the system being studied. It involves the collection of the data necessary to meet the goals of the defined study.

- Life cycle impact assessment (LCIA) provides additional information to help assess a product system's LCI results so as to better understand their environmental significance.

- Interpretation of the life cycle involves the summary and discussion of the results of an LCI or an LCIA, or both, as a sound basis for conclusions, recommendations and a decision-making process in accordance with the goal and scope definition (ISO, 2006a).

A detailed explanation of the structure and implementation of an LCA is given in detail in Chapter 5 of the LEAP guidelines on nutrient flows (FAO, 2018a).

\subsection{ENVIRONMENTAL IMPACT CATEGORIES}

Life cycle impact assessment aims at understanding and evaluating the magnitude and significance of potential environmental impacts for a product system throughout the life cycle of the product (ISO 14040:2006). The selection of environmental impacts is a mandatory step of LCIA and this selection shall be justified and consistent with the goal and scope of the study (ISO, 2006a).

A distinction must be made between midpoint impacts, which characterize impacts in the middle of the environmental cause-effect chain, and end point impacts, which characterize impacts at the end of the environmental cause-effect chain. End point methods provide indicators at, or close to, an area of protection. The aggregation at end point level and at the areas of protection level is an optional phase of the assessment according to ISO 14044:2006 (ISO, 2006b). Climate change is an example of a midpoint impact category. The results of the LCI are the amounts of greenhouse gas (GHG) emissions per functional unit. Based on a radiative forcing model, characterization factors, known as global warming potentials, specific to each GHG, can be used to aggregate all of the emissions to the same midpoint impact category indicator (e.g. $\mathrm{kg} \mathrm{CO}_{2}$ equivalents per functional unit) (IPCC, 2014). 
Following the guidelines on feed supply chains (FAO, 2016a) and the guidelines on environmental quantification of nutrient flows (FAO, 2018a), the most relevant impact categories are global warming potential (GWP), eutrophication potential (EP), acidification potential (AP), land occupation (LO) and fossil energy use (FEU). Since the use of feed additives significantly acts on feed efficiency and thus influences animal and environmental performance (nitrogen and phosphorus flows), EP and AP are of utmost importance.

These guidelines provide detailed information on the most relevant environmental impact categories for livestock systems. However, the collection of full inventory data allows for the use of various LCIA methods and a broader range of environmental impact categories. Users are encouraged to conduct the environmental assessment as comprehensively as possible within the limits of data and resource availability.

\subsection{NORMATIVE REFERENCES}

The critical framework for the application of this methodology and guidance is based on two normative documents:

- ISO 14040:2006 Environmental management-Life cycle assessment-Principles and framework (ISO, 2006a). These standards give guidelines on the principles and conduct of LCA studies, providing organizations with information on how to reduce the overall environmental impact of their products and services and defining the generic steps that are usually taken when conducting an LCA. This document follows the first three of the four main phases in developing an LCA: goal and scope; inventory analysis; impact assessment and interpretation.

- ISO14044:2006Environmentalmanagement-Lifecycleassessment-Requirements and guidelines (ISO, 2006b). These standards specify requirements and provide guidelines for LCA, including: definition of the goal and scope of the LCA, the LCI, the LCIA, interpretation of the life cycle, reporting and critical review of the LCA, limitations of the LCA, relationship between the LCA phases, and conditions for use of value choices and optional elements.

\subsection{NON-NORMATIVE REFERENCES}

The guidance is also based on non-normative documents:

- ISO 14025:2006 Environmental labels and declarations - Type III environmental declarations - Principles and procedures (ISO, 2006c). This standard establishes the principles and specifies the procedures for developing Type III environmental declaration programmes and Type III environmental declarations, specifically with regard to the use of the ISO 14040:2006 series of standards. Type III environmental declarations are primarily intended for use in business-to-business communication, but their use in business-to-consumer communication is not precluded under certain conditions.

- ISO 14046:2014 Environmental management - Water footprint - Principles, requirements and guidelines (ISO, 2014). This standard establishes the principles and specifies the procedures for developing water footprints for products, processes and organizations. It provides guidance on water footprint assessment as a stand-alone assessment or as part of a larger assessment. Only air and soil emissions affecting water quality are included, but not all air and soil emissions are covered. 
- ISO 14067:2018 Greenhouse gases-Carbonfootprint ofproducts-Requirements and guidelines for quantification (ISO, 2018a). This standard specifies the principles, requirements and guidelines for the quantification and communication of the carbon footprint of a product. It is based on ISO 14040:2006 (ISO, 2006a) and ISO 14044:2006 (ISO, 2006b) for quantification, and ISO 14020:2000 (ISO, 2000), ISO 14024:1999 (ISO, 1999) and ISO 14025:2006 (ISO, 2006c) with regard to environmental labels and declarations for communication.

- Product life cycle accounting and reporting standard (WRI and WBCSD, 2011). This standard of the World Resources Institute (WRI) and the World Business Council for Sustainable Development (WBCSD) provides a framework to assist users in estimating the total GHG emissions associated with the life cycle of a product. It is similar in its approach to the ISO standards, but places more emphasis on analysis, tracking changes over time, reduction options and reporting. In common with PAS 2050:2011 (see below), it excludes impacts from the production of infrastructure, but while PAS 2050:2011 includes "operation of premises" (e.g. retail lighting or office heating), the WRI-WBCSD standard does not.

- ENVIFOOD Protocol, Environmental assessment of food and drink protocol (Food SCP RT, 2013). The European Food Sustainable Consumption and Production (SCP) Round Table developed this protocol to strengthen environmental instruments for use in communication and to support the identification of environmental improvement options. The protocol could be the baseline for developing: communication methods, Product Category Rules (PCR), criteria, tools, data sets and assessments.

- International Reference Life Cycle Data System (ILCD) bandbook - General guide for life cycle assessment - Detailed guidance (EC, JRC and IES, 2010). The ILCD Handbook was published in 2010 by the European Commission Joint Research Centre and provides detailed guidance for LCA based on ISO 14040:2006 and ISO 14044:2006. It comprises a set of documents, including a general guide for LCA and specific guides for LCI and LCIA.

- Product Environmental Footprint (PEF) guide (EC, 2013). The PEF Guide is a general method to measure and communicate the potential life cycle environmental impact of a product, highlighting the discrepancies in environmental performance information.

- PEFCR Feed for food producing animals. (EC, 2018). The Feed PEFCR provide feed-specific guidance on how to implement the requirements of the PEF developed by the European Commission. It was approved and published in April 2018 by the European Commission as an outcome of the Environmental Footprint pilot phase, which included several rounds of public consultation.

- BPX-30-323-0 General principles for an environmental communication on mass market products - Part 0: General principles and methodological framework (AFNOR, 2011). This general method was developed by the French Environment and Energy Management Agency-French Standardization Association (ADEME-AFNOR) stakeholder platform to measure and communicate the potential life cycle environmental impact of a product. It was requested by the Government of France in order to highlight the discrepancies in environmental performance information. Food production specific 
guidelines are also available, along with a large set of product-specific rules on livestock products.

- PAS 2050:2011 Specification for the assessment of the lifecycle of greenhouse gas emissions of goods and services (BSI, 2011). PAS 2050:2011 is a Publicly Available Specification (PAS) as opposed to a standard specification. An initiative of the United Kingdom and sponsored by the Carbon Trust and the Department for Environment, Food and Rural Affairs, PAS 2050:2011 was published through the British Standards Institution (BSI) and uses BSI methods for agreeing on a PAS. It is designed for the application of LCA over a wide range of products in a consistent manner for industry users, focusing solely on the carbon footprint indicator. PAS 2050:2011 has many elements in common with the ISO 14000 series methods, but also a number of differences, some of which limit choices for analysts (e.g. exclusion of capital goods and setting materiality thresholds).

- Guidance for measuring GHG emissions from land, forests, and soils across supply chain (Quantis, 2019). This methodology embeds land-related emissions in product footprints. The guidance includes annexed documents providing detailed information on methodology, including debated challenges and limitations.

- Life cycle metrics for chemical products (WBCSD, 2016). The methodology in these guidelines by the chemical sector is used to assess and report on the environmental footprint of products based on life cycle assessment.

\subsection{GUIDING PRINCIPLES}

Nine guiding principles support users in their application of this sector-specific methodology. The principles are consistent across the methodologies developed within LEAP. They apply to all steps, from goal and scope definition, data collection and LCI modelling, through to reporting. Adhering to these principles ensures that any assessment made in accordance with the methodology prescribed is carried out in a robust and transparent manner. The principles can also guide users when making choices not specified by the guidelines.

The principles are adapted from ISO 14040:2006 (ISO, 2006a), the PEF guide (EC, 2013), the product life cycle accounting and reporting standard (WRI and WBCSD, 2011), PAS 2050:2011 (BSI, 2011), the ILCD Handbook (EC, JRC and IES, 2010) and ISO 14067:2018 (ISO, 2018a) and are intended to guide the accounting and reporting of GHG emissions and fossil energy use. Accounting and reporting of environmental impacts of the production and use of feed additives in livestock production shall accordingly be based on the following principles:

- Life cycle perspective. "LCA considers the entire life cycle of a product, from raw material extraction and acquisition, through energy and material production and manufacturing, to use and end of life treatment and final disposal. Through such a systematic overview and perspective, the shifting of a potential environmental burden between life cycle stages or individual processes can be identified and possibly avoided" (ISO, 2006a, 4.1.2).

- Relative approach and functional unit. "LCA is a relative approach, which is structured around a functional unit. This functional unit defines what is being studied. All subsequent analyses are then relative to that functional unit, as all inputs and outputs in the LCI and consequently the LCIA profile 
are related to the functional unit" (ISO, 2006a, 4.1.4). In these guidelines, the functional unit varies depending on the livestock supply chain on which the feed additives have an impact.

- Relevance. Data, accounting methodologies and reporting shall be appropriate to the decision-making needs of the intended users. Information should be reported in a way that is easily understandable to the intended users.

- Completeness. Quantification of the product environmental performance shall include all environmentally relevant material/energy flows and other environmental interventions as required for adherence to the defined system boundaries, the data requirements, and the impact assessment methods employed (EC, 2013).

- Consistency. Data consistent with these guidelines shall be used throughout the inventory to allow for meaningful comparisons and reproducibility of the outcomes over time. Any deviation from these guidelines shall be reported, justified and documented.

- Accuracy. Bias and uncertainties shall be reduced as far as practicable. Sufficient accuracy shall be achieved to enable intended users to make decisions with reasonable confidence as to the reliability and integrity of the reported information. Remaining bias and uncertainty shall be documented and disclosed.

- Iterative approach. "LCA is an iterative technique. The individual phases of an LCA use results of the other phases. The iterative approach within and between the phases contributes to the comprehensiveness and consistency of the study and the reported results" (ISO, 2006a, 4.1.5).

- Transparency. "Due to the inherent complexity in LCA, transparency is an important guiding principle in executing LCAs, in order to ensure a proper interpretation of the results" (ISO, 2006a, 4.1.6).

- Priority of scientific approach. "Decisions within an LCA are preferably based on natural science. If this is not possible, other scientific approaches (e.g. from social and economic sciences) may be used or international conventions may be referred to. If neither a scientific basis exists nor a justification based on other scientific approaches or international conventions is possible, then, as appropriate, decisions may be based on value choices" (ISO, 2006a, 4.1.8). 



\section{Background information on feed additives}

Feed additives are manufactured and used in animal nutrition to achieve a particular purpose or function along the feed chain. Feed additives are usually not used on farm as such and the feed additive chain comprises multiple actors (Figure 2).

\subsection{MANUFACTURING/PRODUCTION OF FEED ADDITIVES}

\subsubsection{Product description}

A feed additive is defined as a component, part or constituent of any combination or mixture making up a feed, whether or not it has nutritional value in the animal's diet. Ingredients are of plant, animal or aquatic origin, or other organic or inorganic substances (FAO and WHO, 2008). In some feed production chains, feed additive production can make a significant contribution to environmental impacts of feed rations, but feed additives can also contribute to significant mitigation potentials through their application in livestock production. Therefore, feed additives need to be taken into account together with the feed-to-food value chain assessment. Feed additives as well as the overall compound feeds are intermediate products in the life cycle of livestock supply chains. Feed additives can play an essential role in improving animal performance and animal well-being. The production of feed additives

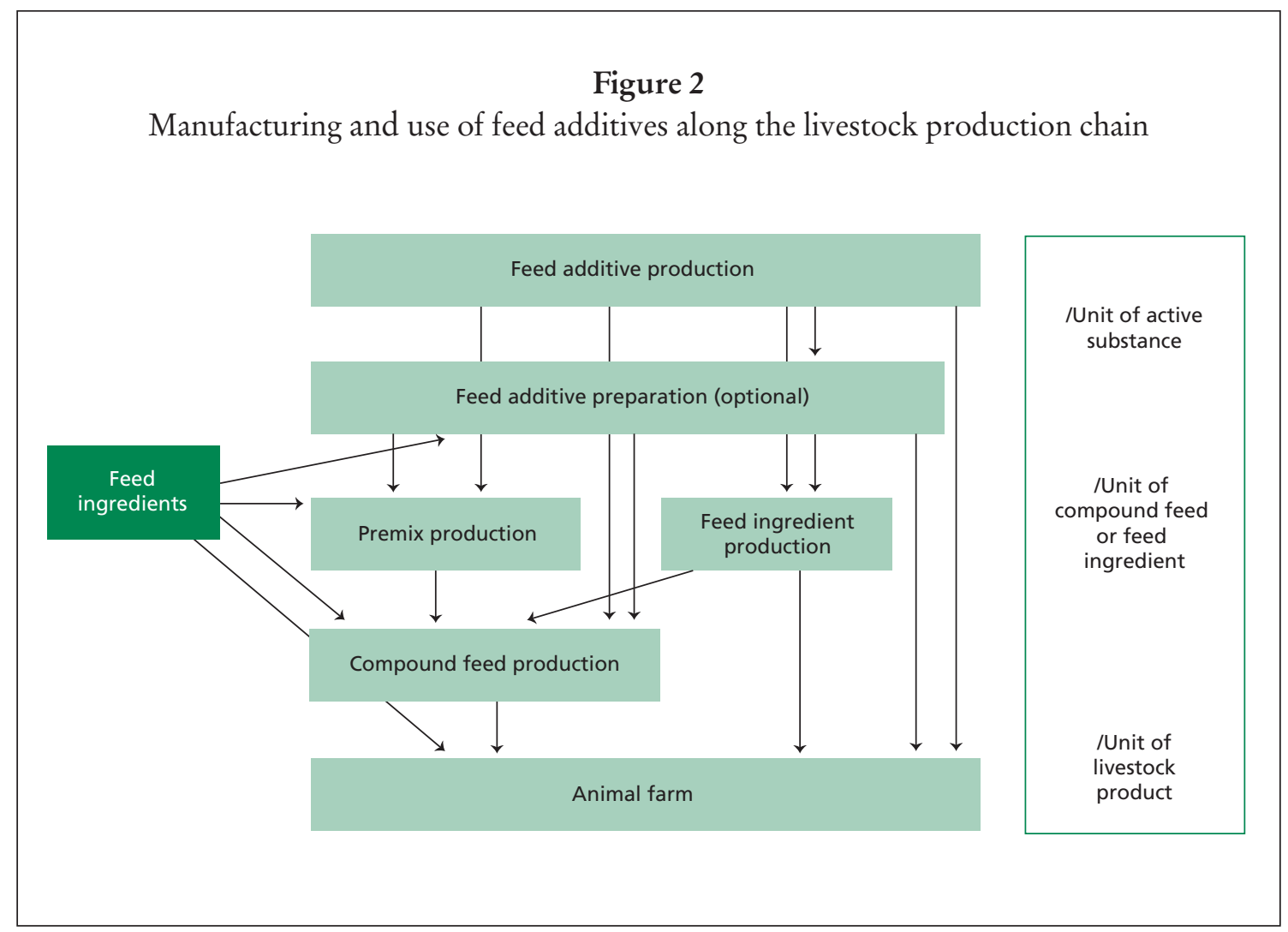


differs from general feed production, because many additives are derived from fossil and mineral materials or manufactured industrially.

The LCA practitioner shall source primary data if available. As an option, secondary data from internationally accepted databases may also be used. A number of commonly used feed additives such as salt, chalk and other minerals can be found in the databases presented in Table 1; however, this is not an exhaustive list. In the absence of information on feed additives in these databases (to be expected in the case of organic compounds such as amino acids and enzymes), the LCA practitioner should look for reviewed and/or validated publications, including papers published in scientific journals, reports from consultants or research institutes, and reports from industry. In addition to the environmental impact of the feed additives, the effect of the additive on animal performance and feed conversion ratio shall be considered to calculate the impact of applying additives along the whole chain.

\subsubsection{Description of the production processes}

Feed additives can be manufactured through different processes. Herein, with regard to modelling and assessment, the various manufacturing processes are divided into four main categories: mining, biomass extraction, chemical process and fermentation. In some cases, the environmental impact of the manufacturing process of the active substance has to be extended when feed additives are placed on the market in the form of a commercial product (i.e. the active substance sprayed on a carrier or a premixture of different active substances) (see section 5.3).

Primary data should be used for robust results of feed additive production, although the production of feed additives might be a small contributor to the overall environmental impacts of livestock products. Hence, if primary data are not available, the practitioner may use default data for feed additive production.

The collection of primary data should be based on the flow chart of the manufacturing process (Figures $3-7$, subsection 4.1.2). The data and modelling results can be presented at different levels of aggregation:

- Level 1: fully aggregated data (all data from levels 1 and 2) of all unit processes

- Level 2: fully or partly disaggregated (from levels 1 and 2 separately) data

The minimum requirement is the disaggregation of processes used for separation (Figure 8). (For a more detailed description of the consequences of data aggregation, see subsection 4.1.3.)

In some cases, the active substance might not be directly usable in a compound feed production system. This could be due to, for example, its limited stability during feed processing or storage. Therefore, feed additive manufacturers produce feed additive that may include not only the active substance but also other ingredients (e.g. antioxidants, carriers). The preparation manufacturing processes can be very diverse and include coating, mixing, granulating and formulation. When a feed additive is used within the feed chain and/or within the livestock production system in the form of a preparation, the environmental impact of the manufacturing of the feed additive shall comprise the environmental impact of both steps: production of the substance/ingredient and its formulation. 
Table 1: Databases that can be used in LCA analysis for collecting secondary data ${ }^{1}$

\begin{tabular}{|c|c|c|c|}
\hline Name & $\begin{array}{l}\text { Database/ } \\
\text { software }\end{array}$ & $\begin{array}{l}\text { Countries/ } \\
\text { Regions } \\
\text { represented }\end{array}$ & Salient features and access points \\
\hline Agribalyse & Database & France & http://www.ademe.fr (Free) \\
\hline $\begin{array}{l}\text { Agri-footprint LCI } \\
\text { data (includes most } \\
\text { FeedPrint data) }\end{array}$ & Database & Global & $\begin{array}{l}\text { LCI database that includes full inventory data expansion } \\
\text { of FeedPrint data } \\
\text { http://www.agri-footprint.com } \\
\text { http://lca.jrc.ec.europa.eu/lcainfohub/datasetArea.vm }\end{array}$ \\
\hline $\begin{array}{l}\text { European } \\
\text { Reference Life } \\
\text { Cycle Database } \\
\text { (ELCD) }\end{array}$ & Database & $\begin{array}{l}\text { European } \\
\text { Union }\end{array}$ & $\begin{array}{l}\text { Data for transport and energy production and some } \\
\text { chemicals and materials (Free) }\end{array}$ \\
\hline $\begin{array}{l}\text { Australian National } \\
\text { Life Cycle } \\
\text { Inventory Database } \\
\text { (AusLCI) }\end{array}$ & Database & Australia & $\begin{array}{l}\text { National and public LCA database for Australia } \\
\text { http://www.auslci.com.au/ (Free) }\end{array}$ \\
\hline ecoinvent & $\begin{array}{l}\text { Database as such } \\
\text { and implemented } \\
\text { in LCA software }\end{array}$ & Global & $\begin{array}{l}\text { Most used database in LCA, limited amount of feed } \\
\text { raw material data } \\
\text { http://www.ecoinvent.ch/ }\end{array}$ \\
\hline $\begin{array}{l}\text { Japan } \\
\text { Environmental } \\
\text { Management } \\
\text { Association for } \\
\text { Industry (JEMAI) } \\
\text { CFP Program }\end{array}$ & $\begin{array}{l}\text { Database } \\
\text { (web-based) }\end{array}$ & $\begin{array}{l}\text { Japan, with } \\
\text { limited } \\
\text { coverage for } \\
\text { other Asian } \\
\text { countries }\end{array}$ & $\begin{array}{l}\text { Database originated by the Japanese Government and } \\
\text { since April } 2012 \text { managed by JEMAI, which has taken } \\
\text { over the responsibility of maintaining the Japanese CFP } \\
\text { scheme } \\
\text { http://www.cfp-japan.jp/english/ (Free) } \\
\text { (English site has limited information) } \\
\text { http://www.cfp-japan.jp/calculate/verify/data.html }\end{array}$ \\
\hline $\mathrm{GaBi}$ & $\begin{array}{l}\text { Software } \\
\text { (graphical user } \\
\text { interface- based) } \\
\text { with database }\end{array}$ & Global & $\begin{array}{l}\text { Thinkstep in partnership with Department of Life Cycle } \\
\text { Engineering at University of Stuttgart developed GaBi } \\
\text { LCA software. Subscription required } \\
\text { http://www.gabi-software.com }\end{array}$ \\
\hline GFLI & Database & Global & $\begin{array}{l}\text { LCI and LCA tools. LEAP and PEF methodology } \\
\text { compliant (Free) } \\
\text { http://globalfeedlca.org/ }\end{array}$ \\
\hline $\begin{array}{l}\text { PEF for agricultural } \\
\text { and food }\end{array}$ & Database & $\begin{array}{l}\text { European } \\
\text { Union feed } \\
\text { supply chains } \\
\text { (includes non- } \\
\text { EU data sets) }\end{array}$ & $\begin{array}{l}\text { Based on Agri-footprint, World Food LCA Database, } \\
\text { ecoinvent and Agribalyse (Free) } \\
\text { To be included in LCA software and available at } \\
\text { http://eplca.jrc.ec.europa.eu/EF-node/ }\end{array}$ \\
\hline $\begin{array}{l}\text { United States } \\
\text { Department } \\
\text { of Agriculture } \\
\text { (USDA) LCA } \\
\text { Commons } \\
\end{array}$ & $\begin{array}{l}\text { Database } \\
\text { (web-based) }\end{array}$ & $\begin{array}{l}\text { United States } \\
\text { of America }\end{array}$ & $\begin{array}{l}\text { United States of America agricultural data (Free) } \\
\text { http://www.lcacommons.gov }\end{array}$ \\
\hline $\begin{array}{l}\text { U.S. Life-Cycle } \\
\text { Inventory (LCI) } \\
\text { Database }\end{array}$ & $\begin{array}{l}\text { Database } \\
\text { (web-based) }\end{array}$ & $\begin{array}{l}\text { United States } \\
\text { of America }\end{array}$ & $\begin{array}{l}\text { Database providing individual gate-to-gate, } \\
\text { cradle-to-gate and cradle-to-grave accounting of } \\
\text { the energy and material flows into and out of the } \\
\text { environment that are associated with producing a } \\
\text { material, component, or assembly in the United States of } \\
\text { America (Free) } \\
\text { http://www.nrel.gov/lci/ }\end{array}$ \\
\hline
\end{tabular}

${ }^{1}$ Updated from Table 4 in the LEAP guidelines on animal feeds supply chains (FAO, 2016a).

\section{i. Mining}

The system boundaries of the mining process depend on the details of the specifically given process. Modelling shall entail the following process steps (Figure 3):

- Mining

- Processing (e.g. purification, further extraction)

- Packaging (if appropriate) 


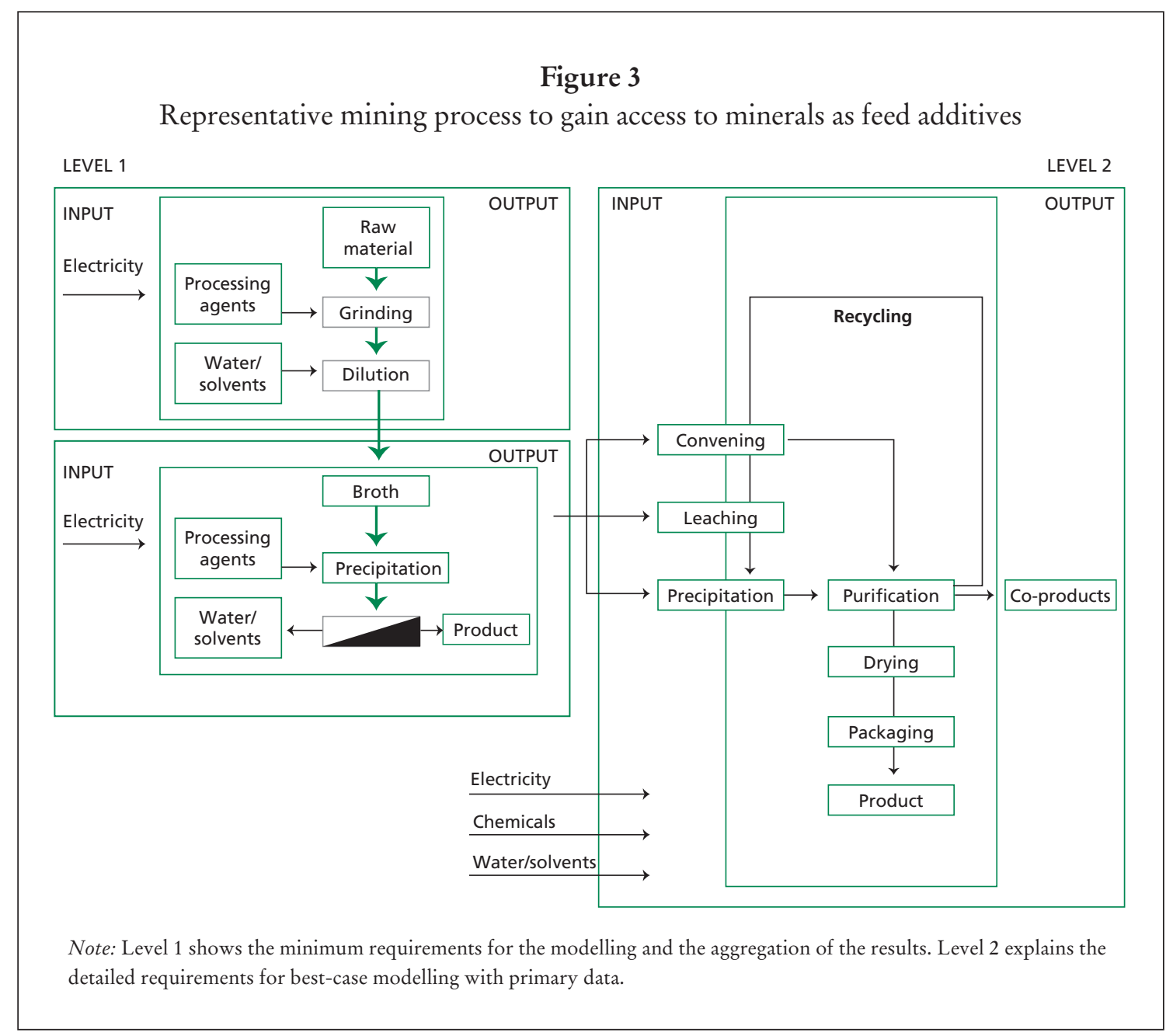

\section{ii. Biomass extraction}

Figures 4 and 5 define generalized requirements for production of most types of plant- and algae-based feed additives; variable production systems will have variable input requirements and waste management. Feed additives derived from terrestrial plants may be sourced from traditional soil-based cultivation or greenhouse operations including hydroponics; additives derived from aquatic plants and algae (micro- or macroalgae) may be sourced from natural or man-made water systems cultivation or land-based tank and bioreactor operations. There may also be wild harvest of plants and algae; this removes the cultivation aspect of the LCA, but harvesting inputs and outputs still apply.

The outputs from these systems prior to harvest are generally due to losses of water, nutrients and chemicals in the form of run-off, including drainage and greenhouse gases. Nutrients added into the system as fertilizer are determined by the associated deficiencies of the growth media and those required to achieve optimum productivity of the system. These may be chemical or organic in nature, or waste nutrients from other processes.

Most of the differences between plants and algae in terms of feed additive production reside in the cultivation. Post-harvest differences are minor and generally relate to handling and storage. Cleaning of the biomass may be required to remove 
Figure 4

Representative process for the extraction of feed additives from plant-based biomass

LEVEL 1

LEVEL 2

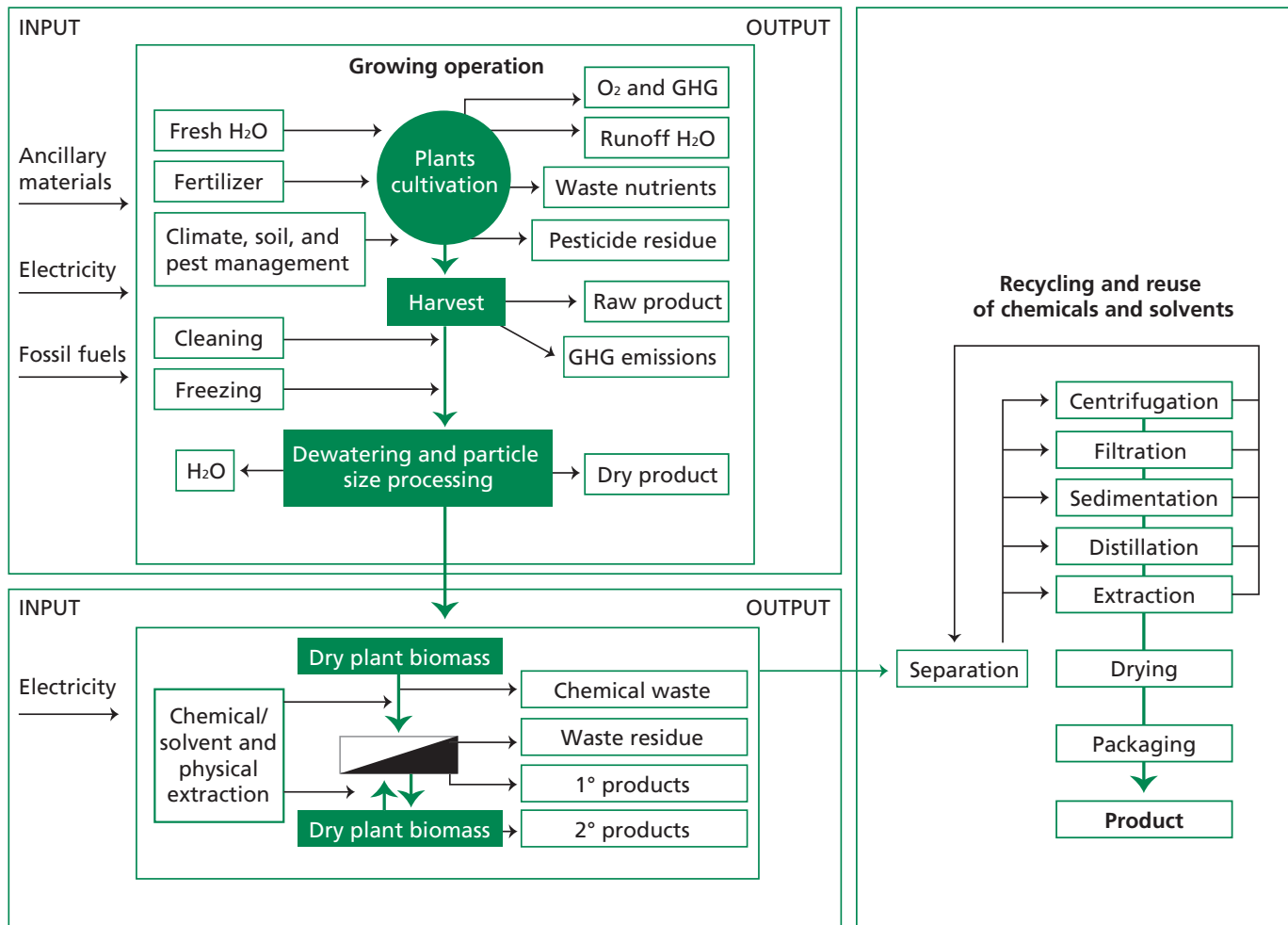

Note: Level 1 shows the minimum requirements for the modelling and the aggregation of the results. Level 1 refers to production to the point of separation, further purification and packaging. Level 2 explains the detailed requirements for best-case modelling with primary data and encompasses separation, purification and packing.

undesired entities such as fouling organisms, salt, pesticides and detritus. In some cases, plant- and/or algae-based feed additives might be further processed - for example, through conversion of biomass components into another chemical form such as transesterification or pyrolysis. For this reason, in addition to the basic cultivation stage described herein, the chemical synthesis processes shall be included.

The system boundaries of the process on the extraction of feed additives from any type of biomass depend on the details of the specifically given process. Modelling shall cover the following process steps (Figure 4):

- Biomass production

- Biomass extraction

- Biomass purification and further chemical modifications

- Biomass packaging

The exact steps depend on whether the biomass is plant or algae based:

- Plant-based biomass: extraction, purification, packaging (if appropriate) and solvent recycling (if appropriate) (Figure 4).

- Algae-based biomass: algae production, extraction (e.g. energy linked to extraction), purification, packaging (if appropriate) and solvent recycling (if appropriate) (Figure 5). 
Figure 5

Representative process for the extraction of feed additives from algae-based biomass

LEVEL 1

LEVEL 2

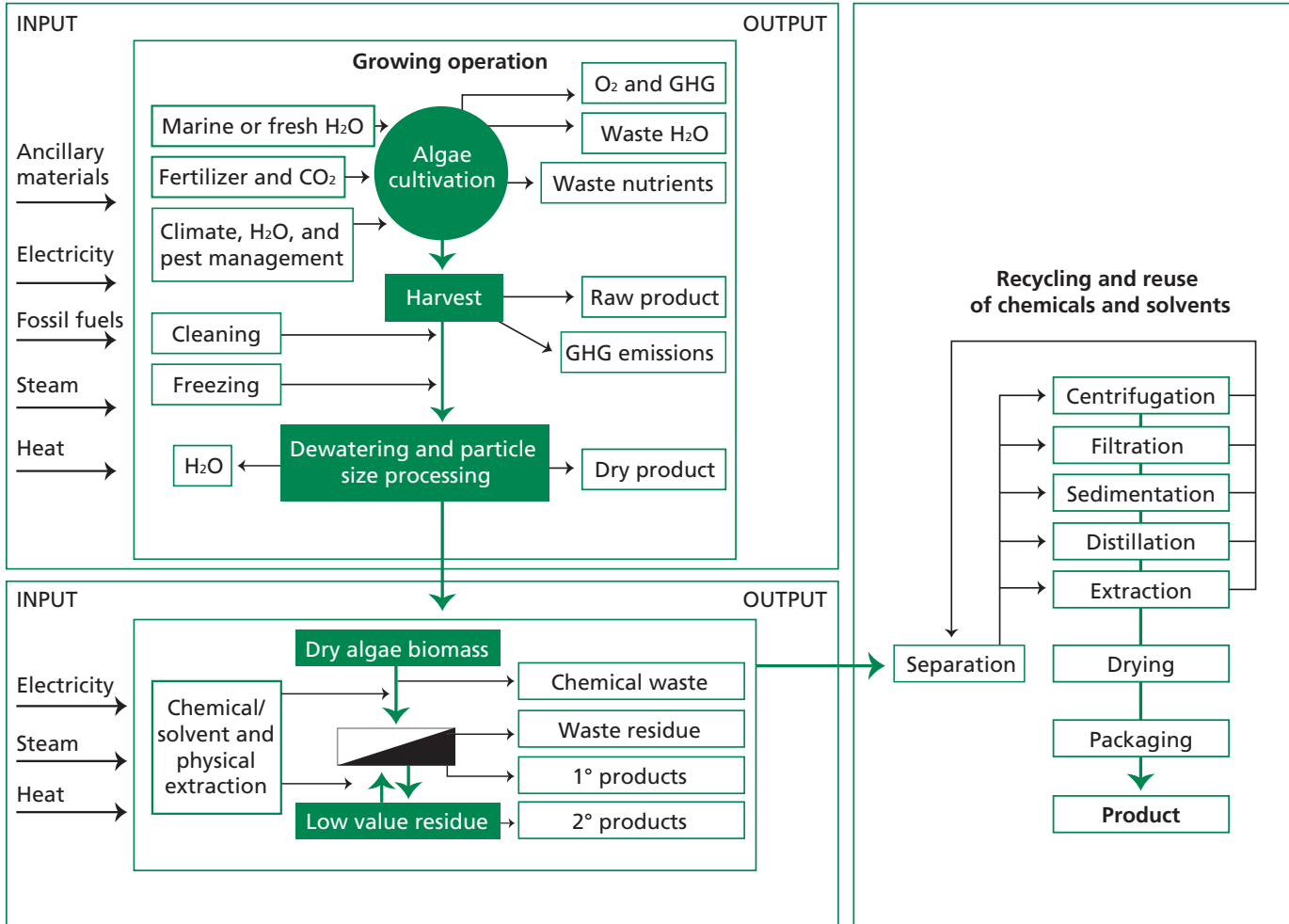

Note: Level 1 shows the minimum requirements for the modelling and the aggregation of the results. Level 1 refers to production to the point of separation, further purification and packaging. Level 2 explains the detailed requirements for best-case modelling with primary data and encompasses separation, purification and packing.

\section{iii. Chemical process}

Starting from mostly petrochemical-derived raw materials, a complex multistep chemical process transforms these molecules into specific feed additives. These processes are performed in large-scale facilities under optimally controlled reaction conditions, ensuring a highly efficient process. These products can be in dry or liquid form and can be further reacted or coated to produce preparations of additives. Depending on the dedicated use of the resulting products, different types of downstream steps for isolation, drying or further processing can be applied.

The system boundaries of the process on the chemical synthesis of feed additives depend on the details of the specifically given process. Modelling shall entail the following process steps (Figure 6):

- Sourcing of raw materials

- Chemical process (e.g. energy, water use)

- Separation and purification

- Packaging (if appropriate)

- Solvent recycling (if appropriate) 


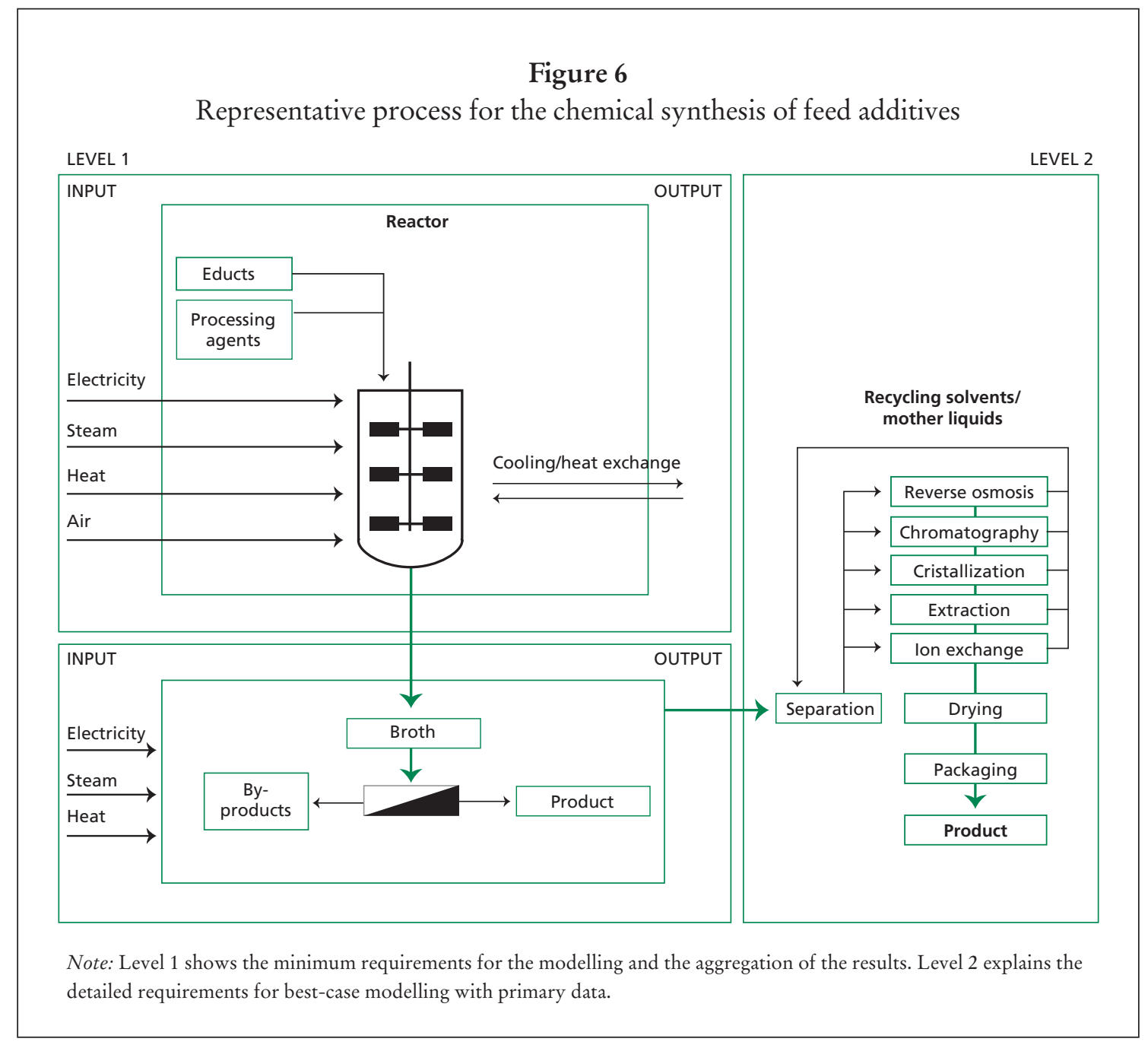

\section{iv. Fermentation}

Figure 7 is a generalized flow diagram for the production of feed additives by fermentation. A representative example, the description is based on various documentations of biotechnological production. Advanced modern biotechnology has allowed rapid progress to be made in the selection of specialized microorganisms that transform carbohydrates (e.g. starch and sugar) and fatty acids through fermentation into feed additives. Sufficient quantities of nitrogen and a range of micronutrients must also be supplied during the process. Hygiene and control of the conditions with the fermenter are critical; they are continuously monitored to ensure optimal production and product quality.

Following fermentation, the microorganisms in the substances are inactivated and further processing steps are implemented to produce the various end products. Depending on the dedicated use of the resulting products, different types of downstream steps for isolation, drying or further processing can be applied.

For probiotics, the microorganism is separated from the fermentation broth and further processed (coated or placed on carrier or lyophilized) before packaging.

The system boundaries of biotechnological processes such as fermentation for production of feed additives depend on the details of the specifically given process. 
Figure 7

Representative process for the biotechnological synthesis of feed additives

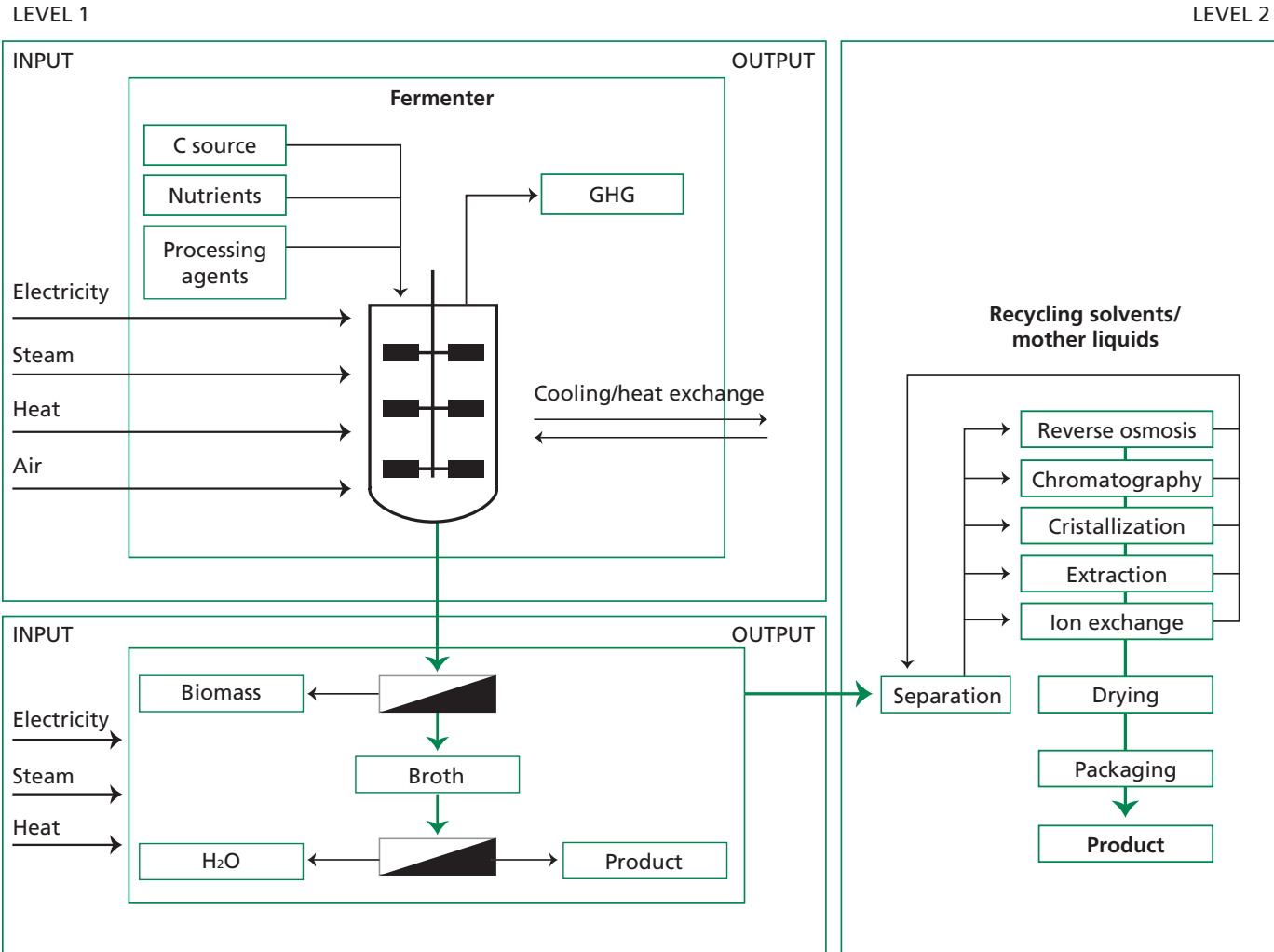

Note: Level 1 shows the minimum requirements for the modelling and the aggregation of the results. Level 2 explains the detailed requirements for best-case modelling with primary data.

Modelling entails the following process steps (Figure 7):

- Sourcing of raw materials and of production organism

- Fermentation process (e.g. energy, water use)

- Separation

- Purification process (if appropriate)

- Packaging (if appropriate)

- Solvent recycling (if appropriate)

\subsubsection{Modularity}

This guidance covers the feed additive chain from the extraction/production of raw materials to the time when feed formulations are ingested by farm animals. There is a wide range of feed additives produced by different technologies (subsection 4.1.2), as described above. To deal with the variety of feed additive supply chains and to preserve maximum flexibility, this guidance and methodology is based on a modular approach enabling users to utilize only those modules that are relevant to the feed additive production under evaluation. Figure 8 provides an example of an entire system. 
Figure 8

Generalized system diagram of life cycle stages covered in these guidelines

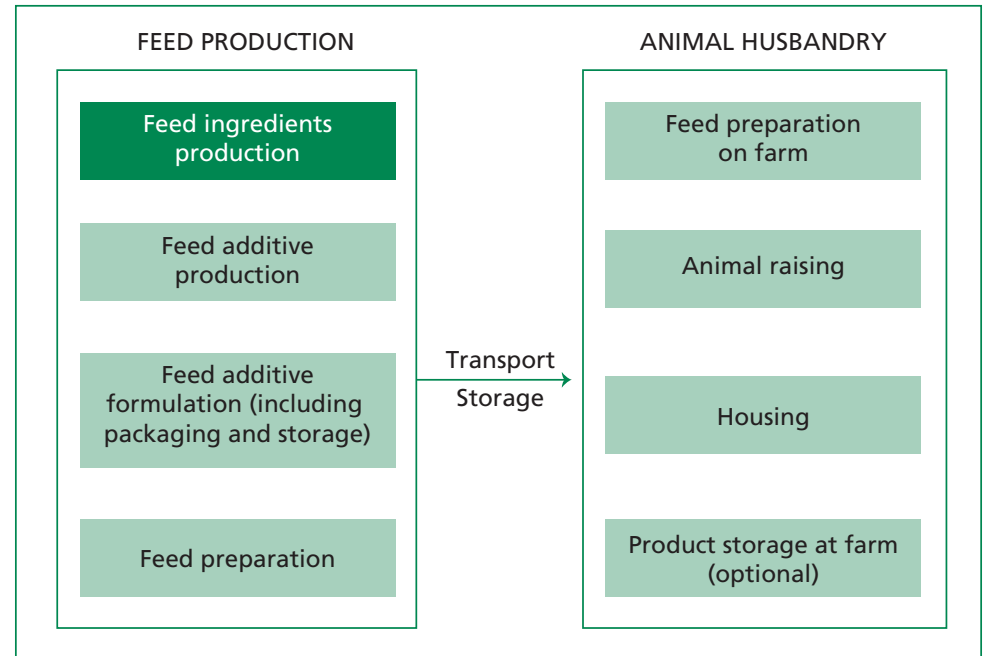

Feed additives belong to the feed production module. Feed additive production can be subdivided into several modules (Figure 8). Feed additives can be used directly after manufacturing, but can also undergo further treatment (e.g. coating, formulation) depending on the type and fate of the active substance or microorganism produced.

Feed additives are then transported to users and may be stored at various points along the supply chain. Transport and the related storage are intermediate steps within the feed production stages. In some situations, traders also play an important role. They may buy the feed additive, store it and transport it to various locations. The upstream and downstream system boundaries depend on the respective stages. For further information, refer to the LEAP guidelines on animal feeds supply chains (FAO, 2016a, 8.4.6).

If the feed additive is stored and transported prior to inclusion in the feed, losses can occur for various reasons. In such cases, the amount of feed additive required shall be corrected for losses.

Feed additive production involves an assembly of unit processes. Data collection can be conducted either at a unit process level or at certain aggregation levels, typically comprising several aggregated unit processes. Figure 9 shows a generic unit process and the associated input and output flows.

In general, the input flows into the processes consist of materials (e.g. acrolein, potassium carbonate), ancillary materials (e.g. lubricant for pumps), energy (e.g. heat, electricity) and in some cases also natural resources (e.g. water, land). Whenever possible, primary inventory data shall be collected for all resources used and emissions associated with the processes under investigation.

Each of the life cycle modules (Figure 10) can comprise several unit processes (subsection 4.1.2). However, the allocation approach for multi-output systems requires that the maximum level of aggregation is defined by the occurrence of byproducts at the unit process level. If the aggregation level is higher, allocation may not be possible (Figure 11). 
Figure 9

Generic unit process within the life cycle inventory

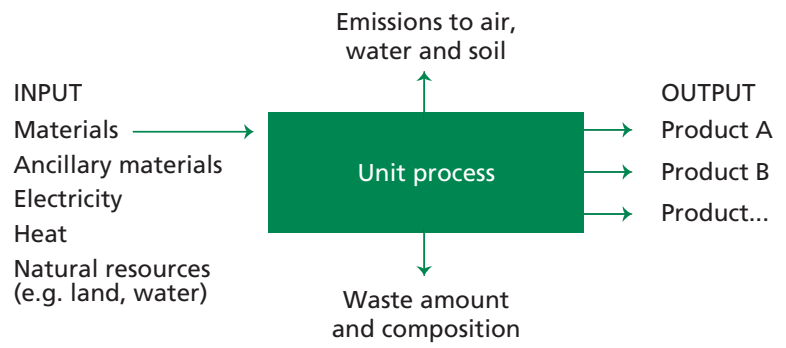

Figure 10

Typical modules for the production of feed additives

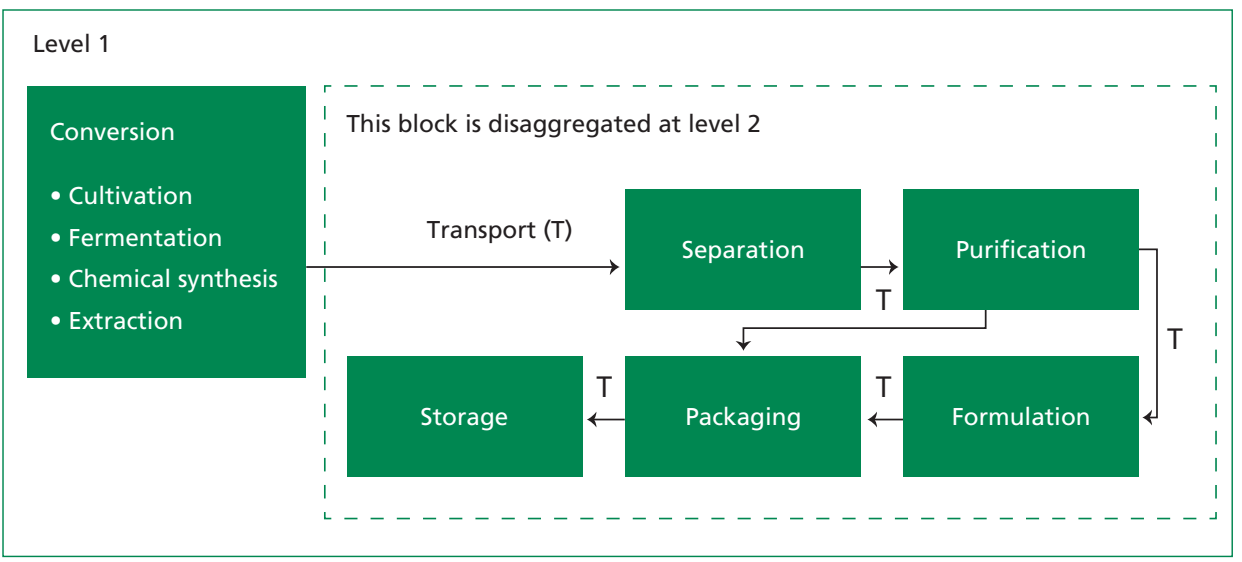

In Figure 11, the input and output flows of four process steps are aggregated (e.g. due to confidentiality issues); a by-product occurs at step 2, at which point allocation may not be a suitable approach because step 3 and step 4 emissions would be allocated to the by-product.

In such cases, three options shall be considered:

- Avoid aggregation of the process steps by subdivision. This option is the preferred one as it leads to more accurate results. When the study is performed, confidentiality issues can be managed using a non-disclosure agreement.

- Use substitution. However, substitution/crediting can have a substantial impact on the final results. As recommended in the LEAP guidelines on animal feeds supply chains (FAO, 2016a), substitution shall only be used in situations where there is clearly no ambiguity about the avoided external production. 
Figure 11

Virtual example for aggregated systems

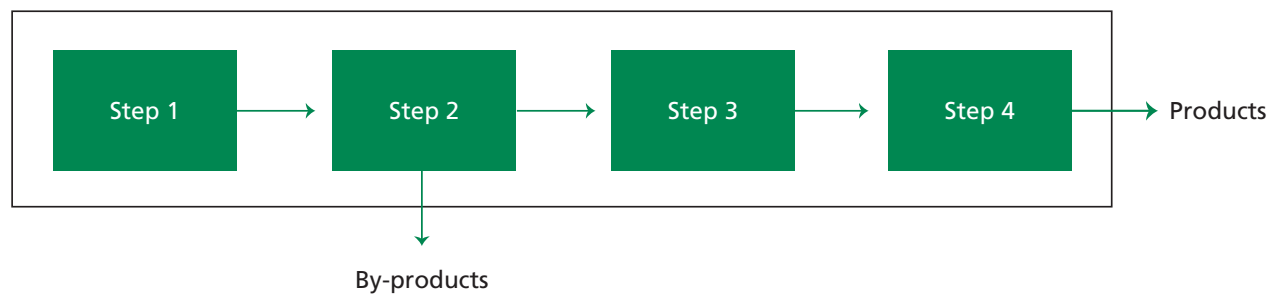

In addition, it is recommended to conduct a sensitivity analysis to show the consequences of the modelling choice for substitution.

- Use allocation. Take into account that it was not possible to sufficiently disaggregate the process in the interpretation of the results.

- For more information on product multifunctionality, refer to the LEAP guidelines on animal feeds supply chains (FAO, 2016a, Chapter 9).

\subsection{USE OF FEED ADDITIVES}

Feed additives are usually incorporated in feeds and may influence:

- feed composition;

- feed conversion efficiency - due to modification of the feed consumption and/or of animal performance (milk, meat, egg, wool);

- reduction of feed losses - through, for example, improved preservation during handling and storage); and

- mitigation of environmental emissions - due to changes in the excreta composition and/or directly as a result of emission modification.

\subsubsection{Feed composition}

Feeds are composed of a combination of different feed ingredients with the aim of providing the animal with macronutrients (e.g. protein, carbohydrates, fat) and micronutrients (e.g. vitamins, minerals) for maintenance, growth, reproduction and production (e.g. milk, meat, eggs). Depending on the livestock production system, feed composition is limited by the availability of feed ingredients and cannot be modified easily. The feed can be produced at the farm level or purchased outside the farm.

In most developed systems, feed composition is defined through IT-based formulation programmes that consider on the one hand, the nutritional quality of the different available feed ingredients, and on the other, the nutritional quality of the feed, in line with the animals' requirements. The nutritional constraints on the feed (e.g. level of crude protein, digestible amino acids, digestible phosphorus) are defined based on animal performance objectives, while each feed ingredient is characterized by nutritional values to achieve the nutritional constraints of the feed. The formulation programme then investigates, analyses and indicates how best the available feed ingredients can be combined effectively and efficiently to achieve the 
nutritional constraints (Al-Deseit, 2009). In most cases, the programme aims to produce a feed composition at least cost (least-cost formulation).

Feed additives may be used to improve the nutritional value of feed ingredients by increasing their digestibility and/or by making nutrients present in these feed ingredients more available for the animals, particularly for monogastric animals (pigs and poultry). By increasing the availability of nutrients from specific feed ingredients, the nutritional value of those ingredients is modified compared to the others. Hence, their potential incorporation rate in feed might be modified using least-cost formulation. As a consequence, the composition of the feed (i.e. the different feed ingredients used and their incorporation rate) might be modified, while the nutritional characteristics of the feed remain unchanged.

Alternatively, some feed additives might be used to improve the digestibility of specific nutrients, particularly proteins, starch and non-starch polysaccharides, and phosphorus, enabling a change in the nutritional constraints of the feed (e.g. reducing the crude protein content in feed). This change usually leads to an alteration in the relative value of the feed ingredients used for the formulation and hence a modification of the feed composition.

This modification of the feed composition can have an impact on the environmental footprint of animal-sourced products, considering that more than 50 percent of the animal production footprint is related to feed ingredients (Wiedemann, McGahan and Poad, 2012). Reduced N intake or increased N digestibility will have a proportional effect of reducing excreted $\mathrm{N}$ and therefore manure $\mathrm{N}_{2} \mathrm{O}$. Examples of modification of feed composition are provided in Appendix 2 for further reference.

\subsubsection{Feed conversion efficiency}

Feed conversion efficiency is calculated as the ratio between the quantity of feed consumed by the animals and the quantity of animal-sourced food derived from them. Feed conversion efficiency depends on:

- feed consumption of individual animals ( $\mathrm{kg}$ feed $/ \mathrm{kg}$ animal-derived product);

- animal performance;

- animal health and welfare, including mortality or morbidity in the flock, particularly for meat and wool production (the rate of mortality affects the overall performance of a group of animals and the feed consumption prior to an animal's death must be taken into consideration); and

- quality - i.e. the marketability - of the animal-sourced product.

In this context, the quality of the animal-sourced product is linked to its compliance with food safety requirements (e.g. low somatic cell count), food quality standards (e.g. proper pigmentation of eggs) and/or percentage of condemnation of carcass (e.g. carcass conformation and composition). This affects primarily the quantity of products sold, hence the overall emission intensity of the animal production.

Different types of feed additives may influence feed efficiency, either by reducing feed consumption, increasing performance and improving the quality of animalsourced products, or by reducing mortality/morbidity. Feed additives might be classified based on their effect on:

- feed digestibility (through nutrient availability or stabilized gut microflora);

- animal-sourced product quality;

- reproduction and hatchability; and

- animal health and welfare maintenance. 


\section{i. Feed digestibility}

The digestibility of feed is an important contributor both to feed efficiency and to the environmental impact of feed production on livestock production. With the exception of ruminants, which are able to digest a large variety of feeds (in particular diets with a high percentage of fibres), monogastric animals (pigs and poultry) are not able to digest fibres efficiently. For this reason, a high energy diet for monogastric animals comprises mainly feed ingredients with high digestibility (e.g. cereals and legumes). Feed additives can be used to improve the digestibility of feed ingredients containing a higher level of undigestible nutrients (e.g. fibres), thereby increasing their energy, amino acid and/or mineral values.

By increasing feed digestibility, the availability of nutrients (carbohydrates, fatty acids, amino acids and minerals) present in the animal diet is increased. As a consequence, either animals need less feed to achieve their physiological requirements (maintenance, production) or they can produce more (e.g. by increasing their growth rate or milk/egg production).

Increased feed digestibility can be achieved either by acting on the nutrient availability in the diet or by improving the gastrointestinal tract function (e.g. influencing the microbiome). See Appendix 1 for a description of the mode of action of enzymes.

\section{ii. Marketability of animal products}

The marketing of animal-sourced products (whether nationally or globally) is linked with adherence to food quality standards such as the acceptable concentration of the somatic cell count in milk or the organoleptic quality of the animalsourced product (e.g. pigmentation). Feed additives might be incorporated into feed with the objective of improving the standardization of products, hence facilitating and securing their compliance with food quality standards. As a consequence, the quantity of animal-sourced food marketed increases leading to less waste and decreased environmental impact intensity of the product. Examples of such effects are described in Appendix 2 for further reference.

\section{iii. Reproduction and hatchability}

Feed additives which can increase the rate of fertility and hatchability have the potential to, for example, decrease unhatched eggs and reduce hatchery waste or increase the life span of reproductive animals.

\section{iv. Animal health and welfare maintenance}

Several types of additives contribute to the stabilization of the physiological conditions of the animals, especially by supporting the gut function. This is the case, for example, for probiotics, prebiotics, some enzymes, organic acids and phytochemicals. Coccidiostats acting against parasites also contribute to animal health and welfare maintenance. Healthier animals spare the burden to restore metabolic functions and can develop and/or produce more efficiently. The benefits of such additives translate into enhanced production parameters and often into enhanced feed efficiency. However, any loss in production or production efficiency implicates an increase in production elsewhere to maintain the overall level of production. This again entails additional feed use with the respective environmental impacts elsewhere (leakage). 


\subsubsection{Reduction of feed losses}

Feed production is one of the most impacting aspects of animal production. Hence, it is important to ensure that the great majority of the nutrients in feed ingredients and feeds produced are delivered to the animal's mouth. To this end, the use of feed additives (e.g. antioxidants, preservatives) and silage additives provides tools to reduce feed losses along the chain:

- Antioxidants. Some feed ingredients, particularly oils and fats, are particularly sensitive to oxidation. Oxidation leads to the degradation of the quality of lipids contained in these products, which can be rendered unsuitable for feeding to animals. In animal production, free radical generation and lipid peroxidation are responsible for developing various diseases as well as for decreasing animal productivity. Antioxidants are used to prevent the oxidative degradation of feed ingredients, thereby maintaining their suitability for feed production and reducing the quantity of feed being discarded from animal nutrition.

- Preservatives. When stored after harvest, feed ingredients are sensitive to the development of moulds and microorganisms that affect feed quality. For example, the development of mycotoxins during feed storage may exert a negative impact on feed intake and feed efficiency.

- Silage additives. Silage is one of the technologies used for the preservation of roughages and other feed ingredients containing high levels of humidity. Access to silage enables the provision of feed during periods of the year when the animals are not able to graze outside. Silage technology is based on the rapid fermentation of the stored roughage, leading to depletion of oxygen and the production of lactic acid and propionic acid, all of which limit the potential for growth of non-desirable microorganisms and moulds that could deteriorate the feed. In certain cases, the silage technology necessitates the use of feed additives to facilitate or even allow the rapid decrease of $\mathrm{pH}$ in the feed ingredients, guaranteeing its stability during storage. The development of moulds leads to feed ingredients being discarded from the animal nutrition, but also leads to the presence of mycotoxins that have a negative impact on feed efficiency.

\subsubsection{Modification of environmental emissions}

There are three main sources of emissions from animal production:

- Enteric methane emissions

- Gaseous emissions from manure storage (ammonia, methane and nitrous oxide)

- Concentrations of nutrients, minerals and feed additive metabolites in the manure

\section{i. Enteric methane emissions}

Livestock systems, particularly ruminants, contribute to greenhouse gas emissions, particularly in the form of enteric methane (NASEM, 2018). A review of mitigation optionsfor enteric methanefrom ruminants showed thatsome of the effectivestrategies include increasing forage digestibility, replacing grass silage with corn silage, feeding legumes and adding dietary lipids and concentrates (Hristov et al., 2013). Although effective, these types of system management options may not offer the scale of reduction required to dramatically change the contribution of agriculture to 
the global GHG inventory and the subsequent negative effects on climate change. However, several studies suggest that feed additives may play a potentially vital role in emissions reduction methodology. Feed additives have been tested to reduce methane emissions. For example, Appuhamy et al. (2013) showed a reduction of about 10 percent using ionophores, specifically monensin in dairy and beef diets. Nitrates have also revealed the potential to reduce emissions by 16 percent (van Zijderveld et al., 2011). Dijkstra et al. (2018) conducted a meta-analysis on the effect of 3-nitrooxypropanol to reduce methane emissions and reported that it is effective in reducing enteric methane by 39 percent in dairy and 22 percent in beef. Seaweed is reported to have an antimethanogenic effect that reduces methane yield during in vitro fermentation (Kinley et al., 2016); this was confirmed in vivo using sheep (Li et al., 2018) and dairy cattle (Roque et al., 2018).

\section{ii. Gaseous emissions from manure}

Manure management, including storage, handling and field application, can be a source of emissions of methane, nitrous oxide and ammonia. The rate of emissions varies depending on the nitrogen quantity in the manure and the physicochemical characteristics (e.g. $\mathrm{pH}$ in liquid manure). Manure management practices adopted by farmers can influence the magnitude of GHG emissions. Nitrous oxide is produced by the process of nitrification and denitrification in soil following manure addition (Chadwick et al., 2011), and the magnitude of the emissions is affected by climate, soil type, application strategy and the composition of the manure (Sommer et al., 2009; Chadwick et al., 2011). Manure from livestock production contributes to between 30 and 50 percent of the global $\mathrm{N}_{2} \mathrm{O}$ from agriculture (Oenema et al., 2005). While the major sources of methane emissions in agriculture are enteric fermentation and rice paddies, anaerobic decomposition of organic matter in manure also results in the formation of $\mathrm{CH}_{4}$ (Hellmann et al., 1997). Methane emissions from manure account for between 12 and 41 percent of total agricultural $\mathrm{CH}_{4}$ emissions for most countries (Chadwick et al., 2011) and depend on storage duration, temperature and composition (Monteny, Bannink and Chadwick, 2006). Solid manure is a source of $\mathrm{CH}_{4}$ emissions with losses observed of 0.4 to 9.7 percent of $\mathrm{C}$ from heaps of cattle farmyard manure (Chadwick, 2005; Szanto et al., 2007). Total emissions from solid manure are a function of heat anaerobicity and temperature (Chadwick et al., 2011). The modification of the physicochemical characteristics of the manure through feed additives enables in particular the reduction of emissions of ammonia and $\mathrm{N}_{2} \mathrm{O}$.

\section{iii. Concentrations of nutrients, minerals and feed additive metabolites in the manure}

Nutrient cycling is an important element of the environmental impact of animal production. In more intensive systems, when the production of manure exceeds its capacity to serve as fertilizer, the reduction of the phosphorus and nitrogen excretion by the animals may represent an effective means to reduce the risk of leaching and eutrophication. In addition, improved feed conversion efficiency is a way to reduce nutrient concentration in the manure. 

PART 2

Methodology for quantification of environmental impacts

from manufacturing/production of feed additives 
Part 2 provides recommendations on how to assess the environmental impacts arising from the manufacturing of feed additives, in order to complete the recommendations provided in the LEAP guidelines on feeds supply chains. Specifically, it provides guidance for:

- the life cycle stage "production of feed additives" in an LCA of feed additive production; and

- a cradle-to-gate (whether of a farm or a production facility) LCA of feed additives, which can be performed independently and whose results can be communicated as such or as input for a full LCA of feed or animal products.

The key feature of the LEAP guidelines is to go beyond the accepted standards for some specific topics related to animal nutrition and livestock supply chains. When considering the manufacturing of additives, where there are undisputed applicable sectorial guidelines available, those guidelines should be considered. On the other hand, the assessment and reporting of the environmental footprint of products should be carried out according to the principles laid down in the present LEAP guidelines, which are based on the same ISO principles. For example, in the case of fermentation and/or chemical processes, the World Business Council for Sustainable Development (WBCSD) guidelines (WBCSD, 2014) are the reference for assessing and reporting on the environmental footprint of products based on life cycle assessment. The LEAP guidelines are complementary to international standards on life cycle assessment and environmental footprint and are not intended to replace the WBCSD guidelines. Thus, relevant recommendations or standards such as ISO 14044:2006 (ISO, 2006b) and the PEF Guide (EC, 2013) shall be followed to claim alignment with them and with the present LEAP guidelines. 


\section{Goal and scope definition}

\subsection{GOAL}

The first step in initiating an LCA study is to clearly define the goal or make a statement of purpose. The latter describes the goal to be pursued and the intended use of the results. There are many reasons for carrying out an LCA: the method can be used, for example, for GHG emission management by determining the carbon footprint of products and determining GHG emission hotspots to prioritize emissions reduction along supply chains. Nevertheless, LCAs can go beyond a simple carbon footprint and include other environmental impact categories. Indeed, full LCAs cover environmental impact categories such as eutrophication or acidification and provide detailed information about a product's environmental performance. They can also serve to set progress and improvement targets (ISO, 2006b) and provide a basis for reporting on the environmental impacts of products. However, these guidelines are not intended for the comparison of products or environmental performance labelling.

It is essential that the LCA's goal and scope is accurately defined to ensure that the aims, methods and results are aligned. Fully quantitative studies, for example, will be required for benchmarking or reporting, whereas a lower standard of rigour may serve for analysis of hotspots.

Seven aspects shall be addressed and documented when goals are defined (EC, JRC and IES, 2010):

- Subject of the analysis and major properties of the assessed system-organization, location(s), dimensions, products, sector and position in the value chain.

- Purpose of the LCA study and context in which decisions will be made.

- Intended use of the results: internal use for decision-making or sharing with third parties.

- Limitations associated with the method, assumptions and choice of impact categories, particularly limitations affecting conclusions associated with the exclusion of impact categories.

- Target audience of the results.

- Comparative studies to be disclosed to the public and requiring critical review.

- Identities of the commissioner of the LCA study and relevant stakeholders.

\subsection{SCOPE}

The scope - defined together with the goal in the first phase of an LCA - shall identify the product system or process to be studied, the functions of the system, the functional unit, the system boundaries and the impact categories; it must be defined in such a way that the breadth, depth and detail of the study are compatible and sufficient to achieve the stated goal. In an LCA of feed additives, the scope of the study may need to be modified as information is collected to reflect data availability and techniques or tools for filling data gaps; specific guidance is provided in sections 5.3-5.7. The definition of scope will affect data collection for the LCI. When reporting the results of assessments based on these guidelines, caution is necessary to avoid misinterpretation of the scope and application of the results. 


\subsection{FUNCTIONAL UNITS AND REFERENCE FLOWS}

The concepts of functional unit and reference flow (i.e. a measure of the outputs from processes in a given product system required to fulfil the function expressed by the functional unit) refer to input and output exchanges in the system under study. A functional unit describes the quantified performance of the function(s) delivered by a system, whereas a reference flow refers to intermediate exchanges of data that have been scaled mathematically to ensure precise delivery of the functional unit. Functional units and reference flows shall be clearly defined and measurable (ISO, 2006b).

In these guidelines, the reference flow for feed additive production is $1 \mathrm{~kg}$ of the final product leaving the manufacturing plant and packaged for shipping to the point of consumption.

\subsection{SYSTEM BOUNDARY OF FEED ADDITIVE PRODUCTION STAGE}

The system boundaries for studies of feed additives are a combination of boundaries of the different existing guidelines on feed production (FAO, 2016a) and on livestock (FAO, 2016b, 2016c, 2016d, 2018b) linked to the production of feed containing additives and its uses along the feed chain and on the farm (from cradle to farm gate). The analysis should also include all emissions associated with land use change, linked to the use of specific feed additives. Section 4.2 provides a list of potential changes due to use of feed additives that need to be considered within the system boundary.

A flow diagram of all assessed processes should be drawn indicating where processes were cut off. For the main transformation steps within a system boundary, a process flow diagram shall be produced and used to account for all of the material flows.

\subsection{MATERIAL CONTRIBUTION AND THRESHOLD}

In principle, all relevant exchanges in the inventory should be included; hence, in general, no cut-off applies. Effects of feed additives cannot be included if linked emissions to their production are excluded. Given the relative importance of different flows, cut-off criteria may be adopted to determine whether or not to expend significant project resources to include specific exchanges in the assessment. Exchanges in feed additive supply chains that contribute less than 1 percent of mass or energy flow of a given unit process may be cut off from further assessment but should not be omitted from the inventory. Larger thresholds shall be explicitly documented and justified by the project goal and scope definition. A minimum of 95 percent of the impact for each category shall be accounted for. Larger thresholds should be transparently documented and in compliance with ISO 14044:2006 (ISO, 2006b). Flows contributing less than 1 percent of the environmental impact for a specific unit process may be included in a scoping analysis (see LEAP guidelines [FAO, 2016a, 8.4.8] for further details). The scoping analysis may also provide an estimate of the total environmental impact to evaluate against the 95 percent minimum.

Some environmental impact categories may be sensitive to the flows that have small mass or energy contributions (e.g. processing agents fed to fermenter). Additional effort should be made to reduce the uncertainty associated with these flows. Lack of knowledge regarding the existence of exchanges relevant for a particular system is considered not a cut-off issue but a modelling mistake. The application of cut-off criteria in an LCA is not intended to support the exclusion of known exchanges, rather to help guide the expenditure of resources towards the reduction 
of uncertainty associated with those exchanges that matter the most in the system. According to ISO 14044:2006, when the study is intended for use in comparative assertions that will be disclosed to the public, the final sensitivity analysis of inputs and outputs shall assess the impact of the cut-off criteria (ISO, 2006b). See section 7.2 for details on sensitivity analysis.

\subsection{TIME BOUNDARY FOR DATA}

The time boundary for data shall be representative. In general, data should be averaged over an appropriate period. For products derived from industrial processes (e.g. fermentation, extraction, chemical conversion), annually averaged data should be used. For other processes (e.g. algae or plant production), at least the length of one or more production cycles should be used. If the additive characteristics change during the growing season or harvest periods, then classifications should be made on the basis of the harvest variations of the feed additives or the raw materials the additives are derived from. Further information for the time boundary of data is available in the LEAP guidelines on animal feeds supply chains (FAO, 2016a, 8.4.9).

For the use phase of additive-containing feed, the study shall use a population, technology mix, geography and time period consistent with provision of the functional unit (e.g. broiler chicken, about 5 weeks).

In extensive production systems, it is common for important parameters to vary between years. For example, reproductive rates or growth rates may change based on seasonal conditions. In cases where there may be considerable inter-annual variability in inputs, production and emissions, it is necessary for the 1-year time boundary to be determined using data averaged over 3 years to meet representativeness criteria. An averaging period of 3-5 years is commonly used to smooth the impact of seasonal and market variability on agricultural products.

Note that this section describes the time boundary for data, not the time boundary of a specific management system. When the specific management system or additional system functions (e.g. wealth management, provision of draught power) influence the life cycle of the animal, this must be clearly stated. However, in general, this would not influence the 12-month time boundary for the data.

\subsection{LIFE CYCLE INVENTORY}

\subsubsection{Overview}

This section describes the key steps and requirements with regard to the quantification of emissions and use of resources in feed additive supply chains. The selection of life cycle inventory (LCI) modelling, including the decisions on which data to collect, depends largely on the goal and scope of the study. The LCI analysis phase requires the collection and quantification of inputs and outputs throughout the life cycle stages covered by the system boundary of the individual study. This typically entails an iterative process, as described in ISO 14040:2006 (ISO, 2006a), comprising the following steps:

- collecting the data - using the principles outlined in subsection 4.1.2;

- recording and validating the data;

- relating the data to each unit process and reference unit - including allocation for different co-products; and

- aggregating the data - ensuring that all significant processes, inputs and outputs are included within the system boundary. 
For feed additive production, the system boundary is defined from cradle to feed additive factory gate, including on-site transport, packaging and storage within the production plant. Transport to the feed mill is outside the system boundary of feed additive production.

In many instances, inventory data are not the result of direct measurements, but are a combination of activity-related measurements (primary activity data) and emission factors or parameterized emission factors (calculation models). To clarify the nature of the inventory data, it is useful to differentiate between "measured" and "modelled" foreground system LCI data.

Section 5.7 describes the inventory analysis process for all stages and situations. A step-by-step approach in the life cycle modelling of the feed additive supply chain is recommended, starting with the flow charts in Figures 3-7.

In cases where feed is part of the analysis of a livestock system, the process starts with a breakdown of the animal's ration into single feed products. For every feed additive used, the LCI data shall be collected in accordance with the goal and scope of the analysis. The goal and scope of the analysis affects data collection and the quality of the required data. For an LCA of feed additive production processes, primary data shall be obtained, whereas for a sectoral analysis, data may be obtained from secondary sources such as statistical databases and other high-quality sources.

\subsubsection{Compiling and recording inventory data}

The compilation of the inventory data should be aligned with the goal and scope of the LCA. In general, an inventory of all materials, energy resource inputs and outputs, including products, co-products and emissions, for the product supply chain under study shall be compiled as indicated in subsection 4.1.2 for unit processes. The data recorded in relation to this inventory shall include all processes and emissions occurring within the system boundary. When developing or using life cycle inventories, biogenic carbon emissions $\left(\mathrm{CO}_{2}\right.$ and $\mathrm{CH}_{4}$ from biomass and soil) and carbon emissions from fossil sources shall be reported separately. An exception is made for biogenic carbon emissions for food applications, because all carbon uptake is released (BSI, 2011; FAO, 2016a).

When evaluating the data collection requirements for a project, the influence of the project scope shall be considered. Usually, foreground and background processes are distinguished. Foreground processes are considered under the control or direct influence of the study commissioner and primary data should be used if feasible. As far as possible, primary inventory data should be collected for all resources used and emissions associated with each life cycle stage considered. When possible, data collected directly from suppliers should be used for the most relevant input materials they supply. For processes where the practitioner does not have direct access to primary data, secondary data can be used. It is recommended to apply the materiality principle for data collection, meaning that effort shall focus on aspects and parameters most relevant for determining the environmental performance.

Figure 12 displays the procedure that can be used to collect inventory data for the system under investigation. The first choice is representative primary data in the order of measured, modelled or collected from the supplier. If such data are not available, peer-reviewed data should be used. It might be necessary to adapt peerreviewed data that do not follow the methodology outlined in these guidelines. 
Any data gaps shall be filled using the best available secondary or extrapolated data. When possible, an independent peer review of proxy data sets by experts should be sought, as errors in extrapolation at this point can be significant. Panel members should have sufficient expertise to cover the breadth of LCI data that are being developed from proxy data sets. The remaining data gaps can be filled with proxy data derived either from comparable processes (e.g. similar fermentation processes) or from dummy data following the precautionary principles (e.g. data from the same data classification, such as organic chemicals having the highest environmental impacts for the most relevant impact categories for the system under investigation). When such proxy data are utilized, they shall be reported and justified.

However, it is recognized that for projects with a larger scope, such as sectorial analyses at the national scale, the collection of primary data for all foreground processes may be impractical. In such situations, or when an LCA is conducted for policy analysis, foreground systems may be modelled using data obtained from secondary sources such as national statistical databases, peer-reviewed literature or other reputable sources.

Figure 12

Decision tree for data collection and selection

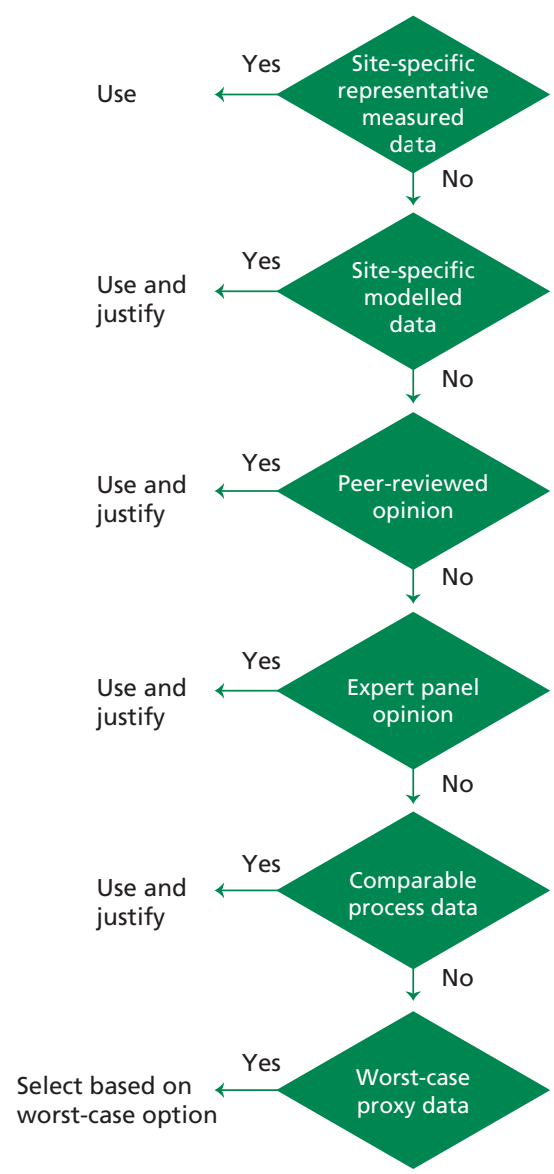


The LCA practitioner shall demonstrate that the following aspects in data collection have been taken into consideration in order to allow an appropriate data quality assessment (adapted from ISO 14044:2006 - ISO, 2006b):

- Representativeness: qualitative assessment of the degree to which the data set reflects the true population of interest. Representativeness covers the following three dimensions:

- temporal - age of data and length of time over which data were collected;

- geographical - geographical area from which data for unit processes were collected to satisfy the goal of the study; and

- technological - specific technology or technology mix.

- Precision: measure of the uncertainty of the data values for each parameter expressed (e.g. standard deviation).

- Completeness: percentage of flow that is measured or estimated.

- Consistency: qualitative assessment of whether the study methodology is applied uniformly to the various components of the analysis.

- Reproducibility: qualitative assessment of the extent to which information about the methodology and data values would allow an independent practitioner to reproduce the results reported in the study.

- Data sources

- Uncertainty of the information: for example, data, models and assumptions. For significant processes, the LCA practitioner shall document data sources, data quality and any efforts made to improve data quality.

- Data gaps: any data gap or exclusion of data shall be reported.

The compilation of inventory data for the use of feed additives is based on the same principles; the modelling rules for calculating emissions from livestock fed with additive-containing feed are explained in Part 3.

\subsubsection{Data quality assessment}

LCA practitioners shall assess data quality by using data quality indicators. Assessing data quality is important for a number of reasons; it improves the inventory's data content for the proper communication and interpretation of results, and informs users about the possible uses of the data. Data quality refers to characteristics of data that relate to their ability to satisfy stated requirements (ISO, 2006a).

Criteria for assessing LCI data quality can be structured according to representativeness (technological, geographical and temporal), completeness in the inventory, precision/uncertainty of the collected or modelled inventory data, and methodological appropriateness and consistency. Representativeness addresses how well the collected inventory data represent the "true" inventory of the process for which they are collected regarding technology, geography and time. For data quality, the representativeness of the LCI data is a key component, and primary data gathered shall adhere to the data quality criteria.

A pedigree matrix can be used to assess the data quality. The pedigree matrix was initially introduced by Funtowicz and Ravetz (1990) and adapted for LCA by Weidema and Wesnaes (1996). The pedigree matrix is widely used for data quality assessment in LCI (Frischknecht and Rebitzer, 2005) and has been slightly modified or adapted by others (Huijbregts et al., 2001). As another example, the data quality rating (DQR) approach, as implemented in the Environmental Footprint methods developed by the European Commission (EC, 2013) can also be used. The DQR is 
a semi-quantitative assessment of the quality criteria of a data set on technological representativeness, geographical representativeness, time-related representativeness and precision. Any deviations from the requirements outlined in subsection 4.1.2 shall apply to both primary and secondary data. 

PART 3

Methodology for quantification of environmental impacts

from using feed additives 
Part 3 provides specific recommendations on how to address the effect of using feed additives on the environmental performance of livestock systems. When such a study is performed, the impacts of the production of the feed additives at stake shall be included in the assessment, following recommendations provided in Part 2. 


\section{Goal and scope definition}

\subsection{GOAL}

The first step when initiating an LCA is to clearly set the goal or statement of purpose. The statement describes the goal pursued and the intended use of results. Within these guidelines, the goal of the study is principally to evaluate the effect of using feed additive(s) on the environmental footprint (e.g. carbon footprint, eutrophication, acidification) of animal products (e.g. milk, meat, eggs), considering the impact of the manufacturing of the feed additive and of on-farm emissions linked to its use.

It is of paramount importance that the goal and scope be given careful consideration because these decisions define the overall context of the study. A clearly articulated goal helps ensure that aims, methods and results are aligned. For example, fully quantitative studies will be required for benchmarking or reporting, but somewhat less rigour may be required for hotspot analysis. Interpretation is an iterative process occurring at every step of the LCA and ensuring that calculation approaches and data match the goal of the study. Interpretation includes completeness checks, sensitivity checks, consistency checks and uncertainty analyses. The conclusions (reported or not) drawn from the results and their interpretation shall be strictly consistent with the goal and scope of the study.

Aspects that shall be addressed and documented during the goal definition are given in section 5.1.

\subsection{SCOPE}

The scope is defined - together with the goal - as part of an iterative process in the first phase of an LCA; it states the depth and breadth of the study. The scope shall identify the product system or process to be studied, the functions of the system, the functional unit, the system boundaries, the allocation principles and the impact categories. The scope should be defined so that the breadth, depth and detail of the study are compatible and sufficient to achieve the stated goal. While conducting an LCA of livestock products, the scope of the study may need to be modified as information is collected, to reflect data availability and techniques or tools for filling data gaps. Specific guidance is provided in sections 6.3-6.9. It is also recognized that the scope definition will affect the data collection for the LCI. As per ISO 14040, in defining the scope of an LCA, the following items shall be considered and clearly described (ISO, 2006a):

- product system to be studied;

- functions of the product system (or, in the case of comparative studies, the systems);

- functional unit;

- system boundary;

- allocation procedures;

- LCIA methodology and types of impacts;

- interpretation to be used;

- data requirements;

- assumptions; 
- value choices and optional elements;

- limitations;

- data quality requirements;

- type of critical review, if any; and

- type and format of the report required for the study.

\subsection{FUNCTIONAL UNITS AND REFERENCE FLOWS}

The functional unit and reference flow in the early stages of the chain (i.e. manufacturing of the feed additive, incorporation of the feed additive in the feed, and delivery to the animals) will be based on $\mathrm{kg}$ of feed additive accompanied by its main function and effects (e.g. incorporation rate of the feed additive in feed). The functional unit and reference flow at farm stage depend on the livestock system in which the feed additive is used and shall correspond to that defined in the relevant LEAP guidelines (FAO, 2016b, 2016c, 2016d, 2018b):

- $1 \mathrm{~kg}$ of live weight for meat-producing animals (pigs, poultry, large and small ruminants);

- $1 \mathrm{~kg}$ of energy-corrected (i.e. fat-and protein-corrected) milk for milk-producing animals (large and small ruminants);

- $1 \mathrm{~kg}$ of egg in shell (poultry);

- 1000 chicks produced;

- $1 \mathrm{~kg}$ of greasy wool (small ruminants); or

- based on goal and scope.

\subsection{SYSTEM BOUNDARY OF FEED ADDITIVE USE STAGE}

The system boundaries of these guidelines are a combination of the boundaries of the different existing guidelines (feed production, livestock-related guidelines) and make the link to the production of feed additives and their uses along the feed chain and on the farm (Figure 1). The manufacturing processes are described on the basis of the different types of materials described in the feed processing guidelines (FAO, 2016a):

- Phytogenic substances are included under the category "crop processing". The particular impact of the extraction process and the possible formulation of the feed additives shall be taken into account, as described in subsection 4.1.2 (ii). Examples of plant extracts are essential oils.

- Animal extracts are included under the category "animal by-products processing”. The particular impact of the extraction/hydrolysis processes and the possible formulation of the feed additives shall be taken into account as described in Chapter 4. Examples of animal extracts are chondroitin sulphate and hydrolysed amino acids.

- Chemical production systems are included under the category of nonbiogenic substances. The particular impact of the production processes and the possible formulation of the feed additives shall be taken into account as described in subsection 4.1.2 (iii). Examples of chemical products are salts and other trace elements; examples of fermentation products are enzymes and live microorganisms.

In addition to the manufacturing processes, it is recommended to account for the effect of additives on various aspects of the livestock production system:

- Preservation of crop products during storage (modification of the crop product footprint due to reduced losses) - e.g. silage agents, preservatives. 
- Impact on the feed formulation - e.g. due to the use of enzymes.

- Impact on the animal production system - e.g. by reducing the feed conversion rate or reducing enteric methane emissions, in relation to the livestockrelevant guidelines.

- Manure management - following the relevant guidelines.

\subsection{TRANSPORT AND TRADE}

Feed additives are transported to users and may be stored at various points along the supply chain. Transport and the related storage are intermediate steps within the feed production stages. The upstream and downstream system boundaries depend on the respective stages, which are given in detail in the LEAP guidelines on animal feeds supply chains (FAO, 2016a, 8.4.6).

\subsubsection{Intermediate transport and trade}

Transport is the connecting link between all phases of production. Transport distances are usually large, as the feed additive business is a global business with localized production. The major means of transport are by road (mainly trucks), sea (mainly for transcontinental deliveries) and air (in some instances for urgent deliveries). Loads range from individual bags (about $20 \mathrm{~kg}$ ) for deliveries by distributors, to full truckloads (about 10 tonnes) and full container loads (about 30 tonnes). A limited quantity of feed additives may be delivered in bulk, but the majority of feed additives are distributed in bags of various weights and using a variety of packaging materials. Transport requires an energy carrier such as fuel or electricity.

Transport can be organized by one of the stages themselves (e.g. receivers or senders). It can also be organized by specialized transporters and traders, whose role may be limited to brokering between the stages in ways that do not affect the transport itself; but when transport is divided into two phases, transporters can have a more important role. In the case of traders, intermediate storage may take place. The same system prevails where feed additives are produced on a continuous basis and feed additive demand is seasonal (e.g. during the winter).

In the case of intermediate storage, energy may be required for conditioned storage (heating, cooling). This energy use shall be taken into account. Transport emissions for the first step (from stage 1 to the intermediate stage) shall be attributed to the smaller percentage $(100-\mathrm{x})$ when leaving intermediate storage. Another scenario is one in which farmers go to the local agent to purchase feed additives, which they then transport themselves. In all cases, transport emissions shall be taken into account. For further information, refer to the LEAP guidelines on animal feeds supply chains (FAO, 2016a, 11.6.1).

6.5.2 Relevant inputs, resource use and emissions during transport and trade i. Transported product

The type of product can provide information about the type of transport required. Liquid products require tankers.

Activity data collection: Data shall be collected regarding the type of transported product. When primary data about fossil fuel for transport are available, data shall be collected regarding the amount of transported product in order to calculate the fuel use per tonne of product.

Emission models and LCI data: Not relevant. 


\section{ii. Fossil fuel use for transport}

Activity data collection: Data shall be collected regarding the direct fuel use, the use per type of fuel and the sulphur content. In the absence of primary data, secondary data on average fuel use (per type of transport and per $\mathrm{km}$ ) and on transport distances shall be sourced from internationally accepted databases.

Emission models and LCI data: When primary data on fossil fuel use are to be collected, an existing transport process shall be modified to ensure that the reported quantity of fuel is considered.

When primary data on fossil fuel use for transport are not known, secondary data shall be amassed from databases. When secondary data on transport emissions are applied, the emissions from production and maintenance have already been incorporated into the emission factor per tonnekm. Steps iii-v are required when primary data on fuel use are not available.

\section{iii. Start and end point of transport}

Activity data collection: Data on the start and end point of the transport shall be collected to calculate the transport distance.

Emission models and LCI data: Not relevant.

\section{iv. Transport means and capacity}

There is wide array of possible means of transport with a broad range of transport capacity. They all have their own emission levels.

Activity data collection: Data shall be collected about the means of transport between the start and end point. When multiple means of transport are used, the start and end point per means shall be identified.

Transport data shall be collected (or defined) on the:

- capacity of the means of transport;

- load factor per transport; and

- empty transport distance (backhaul) per transport (when the transport means is returning empty for a new load, all "empty" kilometres shall be allocated to the originally transported product).

Emission models and LCI data: Emission factors for transport means can be derived from databases. Assumptions on backhaul shall be checked; emission factors shall be corrected when the assumptions differ from the transport under study.

\section{v. Transport distance}

The transport distance shall be calculated after the start point, end point and means of transport have been defined.

Activity data collection: Data shall be collected on the distance between every start and end point in the whole chain of transport. The methodology for calculating transport distances is defined in other LEAP guidelines (e.g. FAO, 2016a).

Emission models and LCI data: Emission can be calculated by multiplying the kilometres per means of transport by the emission factor for the transport means and accumulating all emissions for transporting the product from the original start point to the final end point. 


\section{vi. Storage loss}

Storage loss during transport and trade shall be calculated in the same way as storage loss at the processing stage and compounding stage. For further information, refer to the LEAP guidelines on animal feeds supply chains (FAO, 2016a, 11.6.2).

\section{vii. Fossil fuel use for storage}

Data on fossil fuels shall be collected regarding the direct usage, the usage for storage per type of fuel and the sulphur content. In the absence of primary data, secondary data on average fuel use per type of storage and per tonne and on storage duration shall be gathered from internationally accepted databases.

\section{viii. Electricity use for storage}

Data shall be collected on the basis of the total amount of electricity used, expressed in kilowatt-hours $(\mathrm{kWh})$, regarding the fraction taken from the grid and the fraction produced locally.

For energy taken from the grid, the country-specific energy mix and the related combustion emissions should be taken from internationally accredited sources such as the International Energy Agency (IEA) database. The upstream emissions for the production of the fuels present in the country's mix shall be taken from an internationally accepted database. It should be noted that the IEA data also include the emissions from the production of heat, likely leading to a decrease in totals.

For locally produced electricity, the energy source shall be clearly documented. Emission factors for fossil fuels, biomass, water, wind and solar power shall be taken from an internationally accepted database that takes into account all upstream emissions.

For further information, refer to the LEAP guidelines on animal feeds supply chains (FAO, 2016a, 11.6.2).

\subsection{GENERAL MODEL FOR DERIVING INVENTORY DATA}

The average model per step is expressed by Equation 1 .

Equation 1

$$
\begin{gathered}
(E, R)_{T}=\left(\sum_{i=1}^{a} k m_{a} \times\left(\frac{E F}{\text { tonnekm }}\right)_{a}\right) \times\left(1-\text { loss }_{a}\right)^{-1} \\
+\left(\sum_{i=1}^{b} k m_{b} \times\left(\frac{E F}{\text { tonnekm }}\right)_{b}\right)+(F F)_{s t}+(E L)_{s t}
\end{gathered}
$$

where:

$(E, R)_{T}$

$\sum_{i=1}^{a} k m_{a} \times\left(\frac{E F}{\text { tonnekm }}\right)_{a}$
Emissions and resource use of transport

Transport emissions of step a (to the agent) in the transport and trade scheme for the different kinds of transport used 
$\sum_{i=1}^{b} k m_{b} \times\left(\frac{E F}{\text { tonnekm }}\right)_{b}$

$\frac{E F}{\text { tonnekm }}$

$k m_{a}$

$\left(1-\operatorname{loss}_{a}\right)^{-1}$

$(F F)_{s t}$

$(E L)_{s t}$
Transport emissions of step $b$ (from the agent) in the transport and trade scheme for the different kinds of transport used

Emission factor per tonnekm for a specific means of transport

Transport distance between the start point and the end point of the agent; in the case of suffix b, distance from the agent to the next end point

Net amount of feed after conservation and storage losses

Fossil fuel emissions, for storage

Electricity emissions, for storage

\subsection{CRITERIA FOR SYSTEM BOUNDARY}

A flow diagram of all assessed processes should be drawn that indicates where processes were cut off. For the main transformation steps within the system boundary, it is recommended that a material flow diagram is produced and used to account for all of the material flows.

Spatial system boundaries. The LCA of feed additives shall cover from cradle to farm gate, including raw materials, inputs, production, harvesting, storage, loss and feeding. An LCA should also include all emissions associated with land use and land use change, linked to the use of specific feed materials, in particular when the feed additive is used to modify the feed composition. All emissions directly related to inputs and activities in the feed production chain stages shall be included, irrespective of their location.

\subsection{MATERIAL CONTRIBUTION AND THRESHOLD}

See section 5.5.

\subsection{TIME BOUNDARY FOR DATA}

See section 5.6.

\subsection{LIFE CYCLE INVENTORY (DIETS INCLUDING FEED ADDITIVES)}

\subsubsection{Overview}

Figure 13 shows a simplified overview of the system boundary considered with each production system divided into five processes: production of base feed ingredients, production of feed additives, preparation of feed, animal husbandry and manure management. The analysis shall consider all "upstream" activities from the extraction of raw materials to manufacturing of basic intermediate products, including transportation as described in section 6.5. 


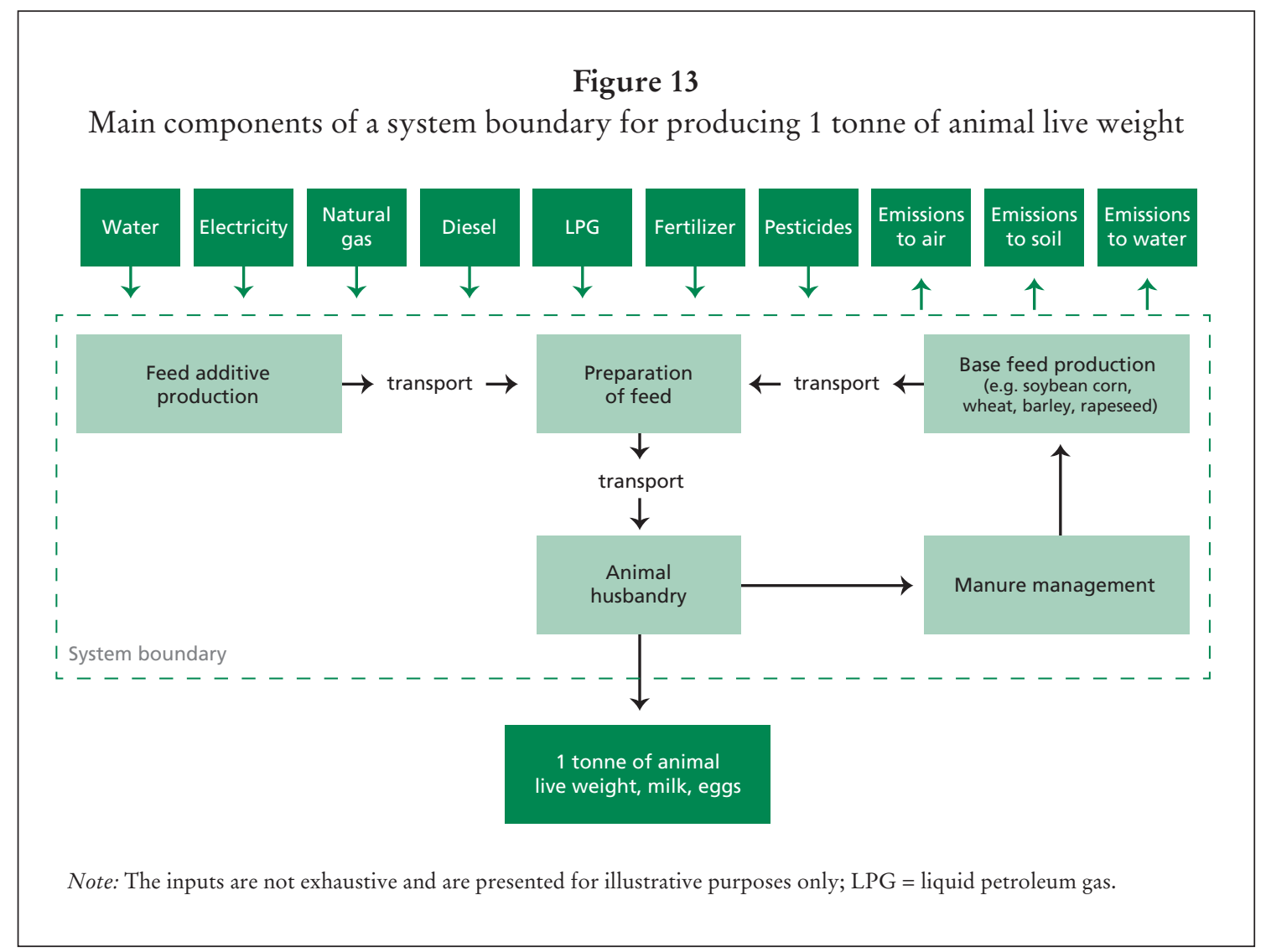

\subsubsection{Compiling and recording inventory data}

The function and the extent of the effect of the feed additive should be based on scientific data, related to the proposed conditions of use of the feed additive. Different levels of scientific data can be envisaged, depending on whether the effect was measured on the specific farm where the LCA is run or is based on practical/research conditions and the number and quality of tests used. In the event that scientific data do not exist for the particular feed additive, references to similar types of feed additive may be used. However, such use shall be limited to the initial evaluation of the feed additive by its developer(s).

Subsection 6.10.3 explains when to apply different modelling rules for animal nutrition.

\subsubsection{Modelling effects of feed additives}

These guidelines provide guidance to compare the environmental impact of the current situation on a farm, a region or a country where similar livestock systems are in place, with the scenario of using a specific feed additive or mixture of feed additives.

The livestock system is based on the type of feed used (e.g. feed ingredient composition, nutritional characteristics), the feeding system (e.g. ad libitum or restricted), the target animal species (e.g. type of animal, breed), the housing system (e.g. slatted floor or partly slatted floor for piglets) and the management system.

The granularity of the system will depend on the effect of the feed additive and the way it is used. As an example, it might be possible to extrapolate the introduction of amino acids in feed for poultry and pig from one livestock system to 
another, but this might not be the case for other types of additives (e.g. enzymes that depend more on the feed composition).

Generally, the LCA will cover the whole production cycle of the animals:

- production of milk, egg and wool - one year;

- reproductive animals (e.g. suckling cows, suckling piglets with sows, breeding hens) - one year; and

- growing animals - either one production cycle (from entry into farm to exit from the farm) or one year (from birth to slaughter weight).

If the feed additive is only provided for a limited period within the production cycle, its impact on the entire life cycle should be taken into consideration. For example, ractopamine may be used in the final weeks of finishing only, but it needs to be evaluated for the full production phase.

The scenario to be evaluated with the feed additive shall be based on the same livestock system as that defined for the baseline.

\section{i. Modification of feed composition}

When use of the feed additive allows modification of the diet composition, the environmental impact of the feed production may also be modified. The evaluation of the environmental footprint of the feed should be calculated as described in the LEAP guidelines on animal feeds supply chains (FAO, 2016a). Furthermore, since feed is an input in the evaluation of the environmental impact of animal-sourced product, the latter needs to be re-evaluated according to the relevant LEAP guidelines.

When the composition change allows a modification of the nutritional composition of the feed (e.g. crude protein content or total phosphorus content), the emissions of the baseline scenario should be recalculated by introducing the variation factor $\Phi_{\mathrm{nc}}$ (nutrient concentration) linked to the use of the additive. Depending on the available data for the feed additives under evaluation, $\Phi_{\mathrm{nc}}$ may be either greater than 1 (when the additive increases the parameter being multiplied), less than 1 (when the additive decreases the parameter being multiplied) or equal to 1 (when the additive has no effect on the parameter being multiplied).

For example, if the feed additive allows to reduce the protein content in the feed by 5 percent compared to the baseline equation (i.e. $\Phi_{\mathrm{nc}}=0.95$ ), the intake of nitrogen by pigs will be modified as follows:

Baseline scenario

Feed additive scenario

where:

FI is feed intake; and

$\mathrm{CP}$ is crude protein.

\section{ii. Feed efficiency}

When the use of feed additives leads to modification of the feed efficiency, the evaluation of the environmental impact of animal production should be modified accordingly to take into account this effect, substantiated for the given feed additive or combination of feed additives. The various approaches depend on the extent to which the feed additives improve feed efficiency and on the animal species under consideration. 
Feed efficiency is the ratio between feed intake and performance (i.e. milk production, growth). Hence, the feed additive or the combination of feed additives might affect one of the parameters or both.

To model the change in emissions linked to the change in feed efficiency, the ratio between the baseline scenario and the scenario with the feed additive is described by $\Phi_{\mathrm{fi}}(\mathrm{f}=$ feed intake $), \Phi_{\mathrm{p}}(\mathrm{p}=$ performance $)$ or $\Phi_{\mathrm{apc}}(\mathrm{apc}=$ animal product composition), which represents the variation in the parameter linked to the use of the additive. Depending on the available data for the feed additives under evaluation, $\Phi_{\mathrm{fi}}$, $\Phi_{\mathrm{p}}$ or $\Phi_{\mathrm{apc}}$ may be greater than 1 (when the additive increases the parameter being multiplied), less than 1 (when the additive decreases the parameter being multiplied) or equal to 1 (when the additive has no effect on the parameter being multiplied). For example, if the feed additive increases the feed intake by 5 percent compared to the baseline equation (i.e. $\Phi_{\mathrm{nc}}=1.05$ ), the intake of nitrogen by pigs will be modified as follows:

Baseline scenario

Feed additive scenario

where:

FI is feed intake; and

$\mathrm{CP}$ is crude protein.

$$
N_{\text {intake }}=F I \times \% C P / 6.25
$$

$$
N_{\text {intake }}=F I \times \Phi_{f i}(1.05) \times \% C P / 6.25
$$

\section{iii. Emission factors}

This subsection applies to feed additives that can have a direct effect on the emissions from enteric fermentation or from manure management. In this case, the ratio between the emission linked to the additive and the emission from the baseline will be affected by the emission factor.

In the following equations, the ratio between the baseline scenario and the scenario with the feed additive is described by $\Phi_{\text {ef }}(\mathrm{ef}=$ emission factor), which represents the variation in the parameter linked to the use of the additive. Depending on the available data for the feed additives under evaluation, $\Phi_{\text {ef }}$ may be greater than 1 (when the additive increases the parameter being multiplied), less than 1 (when the additive decreases the parameter being multiplied) or equal to 1 (when the additive has no effect on the parameter being multiplied). For example, if the feed additive increases the emission factor by 5 percent compared to the baseline equation (i.e. $\left.\Phi_{\text {ef }}=1.05\right)$, the enteric methane $\left(\mathrm{CH}_{4}\right)$ emissions from ruminants will be modified as follows:

Baseline scenario

Feed additive scenario

where:

GE is gross energy; and

$\mathrm{EF}$ is emission factor.

$$
\mathrm{CH}_{\text {4enteric }}(\mathrm{kg})=G E \times(E F / 55.65)
$$

$$
\mathrm{CH}_{\text {4enteric }}(\mathrm{kg})=G E \times\left(\left(E F \times \Phi_{\text {ef }}\right) / 55.65\right)
$$


Table 2: Definition of parameters and variables used in equations

\begin{tabular}{|c|c|c|}
\hline Item & Description & Unit \\
\hline$\%$ CP & $\begin{array}{l}\text { Protein concentration in the diet, considering the protein concentration in } \\
\text { each ingredient and its contribution to the diet expressed on a dry matter basis }\end{array}$ & $\%$ \\
\hline$\% \mathrm{Cu}$ eggs & Concentration of copper in the eggs & $\%$ \\
\hline$\% \mathrm{Cu}$ in tissues and bone & Concentration of copper in the total weight gain, including tissues and bones & $\%$ \\
\hline$\% \mathrm{DE}$ & Percentage of digestible energy in the feed & $\%$ \\
\hline$\% \mathrm{~N}$ in feed & Concentration of nitrogen in the feed & $\%$ \\
\hline$\%$ P eggs & Concentration of phosphorus in the eggs & $\%$ \\
\hline$\% \mathrm{P}$ in milk & Concentration of phosphorus in the milk & $\%$ \\
\hline$\% \mathrm{P}$ in tissues and bone & $\begin{array}{l}\text { Concentration of phosphorus in the total weight gain, including tissues and } \\
\text { bones }\end{array}$ & $\%$ \\
\hline$\%$ Protein in milk & Concentration of crude protein in the milk & $\%$ \\
\hline$\%$ Protein in tissues & Concentration of crude protein in the total weight gain & $\%$ \\
\hline$\%$ Zn eggs & Concentration of zinc in the eggs & $\%$ \\
\hline$\% \mathrm{Zn}$ in tissues and bone & Concentration of zinc in the total weight gain, including tissues and bones & $\%$ \\
\hline$\% \mathrm{Cu}_{\text {total }}$ & $\begin{array}{l}\text { Average concentration of the element in the diet across the various phases of } \\
\text { the feeding programme (using the feeding intake in each phase to weigh the } \\
\text { average concentration) }\end{array}$ & $\%$ \\
\hline$\% \mathrm{P}_{\text {total }}$ & $\begin{array}{l}\text { Average concentration of the element in the diet across the various phases of } \\
\text { the feeding programme (using the feeding intake in each phase to weigh the } \\
\text { average concentration) }\end{array}$ & $\%$ \\
\hline$\% \mathrm{Zn}_{\text {total }}$ & $\begin{array}{l}\text { Average concentration of the element in the diet across the various phases of } \\
\text { the feeding programme (using the feeding intake in each phase to weigh the } \\
\text { average concentration) }\end{array}$ & $\%$ \\
\hline 0.588 & Retention factor for nitrogen in turkeys and laying hens & \\
\hline 0.602 & Retention factor for nitrogen in chickens & \\
\hline 0.656 & $\mathrm{CH}_{4}$ density & $\mathrm{kg} / \mathrm{m}^{3}$ \\
\hline 0.92 & $\begin{array}{l}\text { Default of } 8 \% \text { ash content in the cattle manure (this value shall be modified if } \\
\text { measured or known system-specific values differ from this default) }\end{array}$ & \\
\hline 1.04 & $\begin{array}{l}\text { Default value based on the assumption that } 4 \% \text { of the gross energy can } \\
\text { normally be attributed to urinary energy excretion by most large ruminants }\end{array}$ & \\
\hline 18.45 & Default gross energy value of $1 \mathrm{~kg}$ of dry matter & MJ \\
\hline $44 / 28$ & Factor to convert mass of $\mathrm{N}_{2} \mathrm{O}-\mathrm{N}$ to mass of $\mathrm{N}_{2} \mathrm{O}$ & \\
\hline 55.65 & Energy content of $\mathrm{CH}_{4}$ & $\mathrm{MJ} / \mathrm{kg}$ \\
\hline 6.25 & $\begin{array}{l}\text { Factor for the conversion of nitrogen content to protein content } \\
(\mathrm{CP}=\mathrm{N} \times 6.25) \text { in the feed and in the animal tissues }\end{array}$ & \\
\hline 6.38 & $\begin{array}{l}\text { Factor for the conversion of nitrogen content to protein content } \\
(\mathrm{CP}=\mathrm{N} \times 6.38) \text { in the milk }\end{array}$ & \\
\hline A & $\begin{array}{l}\text { Ash content of the manure, expressed as a fraction (the range is usually } \\
\text { between } 0.1 \text { and } 0.2 \text { ) }\end{array}$ & \\
\hline Bo & $\begin{array}{l}\text { Maximum } \mathrm{CH}_{4} \text { production potential for the excreted manure. Default values } \\
\text { can be found in IPCC (2019) }\end{array}$ & \\
\hline $\mathrm{Cu}_{\text {excreted }}$ & Quantity of copper excreted by the animal during the evaluated period & $\mathrm{kg}$ \\
\hline $\mathrm{Cu}_{\text {intake }}$ & Quantity of copper consumed by the animal during the evaluation period & $\mathrm{g}$ \\
\hline $\mathrm{Cu}_{\text {product }}$ & Quantity of copper stored in the body during the evaluation period & $\mathrm{kg}$ \\
\hline $\mathrm{Cu}_{\text {retention }}$ & $\begin{array}{l}\text { Quantity of copper retained in the animal live weight during the evaluation } \\
\text { period }\end{array}$ & $\mathrm{kg}$ \\
\hline $\mathrm{DM}$ & Dry matter of the feed or diet & $\%$ \\
\hline
\end{tabular}




\begin{tabular}{|c|c|c|}
\hline Item & Description & Unit \\
\hline DMD & $\begin{array}{l}\text { Digestibility of the dry matter in the diet, expressed as a fraction } \\
\text { (could be measured or modelled; measured is the gold standard and the basis } \\
\text { of best-case data) }\end{array}$ & \\
\hline DMI & Measured quantity of dry matter intake from the different feeds & $\mathrm{kg}$ \\
\hline $\mathrm{DMI}_{\text {other }}$ & $\begin{array}{l}\text { Calculated dry matter intake of the other feed sources whose intake is not } \\
\text { measured (e.g. grazing pasture, forages) }\end{array}$ & $\mathrm{kg}$ \\
\hline ECM & $\begin{array}{l}\text { Energy-corrected milk, calculated according to the following equation: } \\
\text { Milk } \times(0.1226 \times \% \text { fat }+0.0776 \times \% \text { true protein }+0.2534)\end{array}$ & $\mathrm{kg}$ \\
\hline EF & $\begin{array}{l}\text { Emission factor referring to the loss of enteric } \mathrm{CH}_{4} \text { based on the gross energy } \\
\text { intake. The EF is on average } 6.5 \%( \pm 1 \%) \text { when large ruminants are fed with } \\
\text { roughages. When large ruminants are fed more than } 90 \% \text { concentrate, diets } \\
\text { are assigned an EF of } 3.0 \%( \pm 1 \%) \text {. }\end{array}$ & \\
\hline $\mathrm{EF}_{\mathrm{MMS}}$ & Emission factor for the relevant manure management system & \\
\hline $\mathrm{ENb}$ & Number of eggs produced during the evaluation period & \\
\hline $\mathrm{EW}$ & Average egg weight & $\mathrm{g}$ \\
\hline$\Phi$ & $\begin{array}{l}\text { Factor of modification of a parameter. It can be less than, equal to or greater } \\
\text { than } 1 \text {. For example, if the parameter is increased by } 5 \%, \Phi=1.05 \text {, and if it is } \\
\text { reduced by } 5 \%, \Phi=0.95 \text {. }\end{array}$ & \\
\hline$\Phi_{\text {bwc }}$ & Factor of modification of body weight composition & \\
\hline$\Phi_{\mathrm{ec}}$ & Factor of modification of egg composition & \\
\hline$\Phi_{\text {ef }}$ & Factor of modification of emission factor & \\
\hline$\Phi_{\mathrm{ep}}$ & Factor of modification of egg production & \\
\hline$\Phi_{\text {fi }}$ & Factor of modification of feed intake & \\
\hline$\Phi_{\mathrm{gp}}$ & Factor of modification of growth performance & \\
\hline$\Phi_{\mathrm{he}}$ & Factor of modification of number of hatched eggs & \\
\hline$\Phi_{\mathrm{mc}}$ & Factor of modification of milk composition & \\
\hline$\Phi_{\mathrm{mp}}$ & Factor of modification of milk production & \\
\hline$\Phi_{\mathrm{nc}}$ & Factor of modification of nutritional composition of feed & \\
\hline$\Phi_{\mathrm{wg}}$ & Factor of modification of weight gain & \\
\hline$\Phi_{\text {wgc }}$ & Factor of modification of weight gain composition & \\
\hline FCR & $\begin{array}{l}\text { Feed efficiency (total feed intake given/final body weight) - may apply to a } \\
\text { given time period or to the total lifespan of the animal }\end{array}$ & $\mathrm{kg} / \mathrm{kg}$ \\
\hline FI & Feed intake, with feed containing $88 \%$ dry matter & $\mathrm{kg}$ \\
\hline GE & Gross energy intake based on total net energy requirement & MJ \\
\hline kg eggs in shell & Amount of egg produced & $\mathrm{kg}$ \\
\hline $\mathrm{MCF}$ & $\begin{array}{l}\mathrm{CH}_{4} \text { conversion factor for the manure management system. Default values can } \\
\text { be found in IPPC (2019). }\end{array}$ & \\
\hline ME & Metabolizable energy content & MJ \\
\hline $\mathrm{ME} / \mathrm{kg} \mathrm{DM}$ & Energy concentration per kg dry matter of the feed sources & $\mathrm{MJ} / \mathrm{kg}$ \\
\hline $\mathrm{ME}_{\text {intakeother }}$ & $\begin{array}{l}\text { Amount of energy consumed from other feed sources } \\
\text { (e.g. grazing pasture forages) }\end{array}$ & MJ \\
\hline $\mathrm{CH}_{4 \text { enteric }}$ & Quantity of enteric $\mathrm{CH}_{4}$ produced by the animal & $\mathrm{kg} \mathrm{CO} 2 \mathrm{e}$ \\
\hline $\mathrm{CH}_{4 \text { manure }}$ & Quantity of $\mathrm{CH}_{4}$ emitted from the manure management system & $\mathrm{kg} \mathrm{CO} 2 \mathrm{e}$ \\
\hline Milk & Production of milk & $\mathrm{kg}$ \\
\hline $\mathrm{NE}_{\text {activity }}$ & Net energy for activity (e.g. grazing) & MJ \\
\hline $\mathrm{NE}_{\text {growth }}$ & Net energy for growth & MJ \\
\hline
\end{tabular}


Environmental performance of feed additives in livestock supply

\begin{tabular}{|c|c|c|}
\hline Item & Description & Unit \\
\hline $\mathrm{NE}_{\text {lactation }}$ & Net energy for lactation & MJ \\
\hline $\mathrm{NE}_{\text {maintenance }}$ & Net energy for maintenance & MJ \\
\hline $\mathrm{NE}_{\text {pregnancy }}$ & Net energy for gestation & MJ \\
\hline $\mathrm{NE}_{\text {wool }}$ & Net energy for wool production & MJ \\
\hline $\mathrm{N}_{\text {excreted }}$ & Quantity of nitrogen excreted during the evaluation period & $\mathrm{kg}$ \\
\hline $\mathrm{N}_{\text {intake }}$ & Amount of nitrogen consumed by the animal during the evaluation period & $\mathrm{kg}$ \\
\hline $\mathrm{N}_{2} \mathrm{O}_{\text {manure }}$ & Amount of $\mathrm{N}_{2} \mathrm{O}$ emitted from the manure management system & $\mathrm{kg} \mathrm{CO} \mathrm{CO}_{2} \mathrm{e}$ \\
\hline $\mathrm{N}_{\text {product }}$ & Quantity of nitrogen exported via milk or stored in the body & $\mathrm{kg}$ \\
\hline $\mathrm{P}_{\text {excreted }}$ & Quantity of phosphorus excreted by the animal & $\mathrm{kg}$ \\
\hline $\begin{array}{l}\text { intake } \\
\end{array}$ & Amount of phosphorus consumed by the animal & $\mathrm{kg}$ \\
\hline $\mathrm{P}_{\text {product }}$ & Quantity of phosphorus exported via milk or stored in the body & $\mathrm{kg}$ \\
\hline$P_{\text {retention }}$ & Quantity of phosphorus retained in the animal live weight & $\mathrm{kg}$ \\
\hline REG & Ratio of net energy for growth to the digestible energy consumed & $\%$ \\
\hline REM & Ratio of net energy for maintenance to the digestible energy consumed & $\%$ \\
\hline Res $\mathrm{D}$ & $\begin{array}{l}\text { Digested fibre, estimated as the difference between digested organic matter } \\
\text { and digested sugar, starch, fat and protein }\end{array}$ & \\
\hline $\mathrm{R}_{\text {MMS }}$ & Fraction of nitrogen lost as gas in an animal manure management system & \\
\hline Total ME requirement & $\begin{array}{l}\text { Total amount of energy required for the maintenance and performance of the } \\
\text { animal }\end{array}$ & MJ \\
\hline TWG & Total weight gain of the animals during the considered period & \\
\hline VS & Volatile solid excreted daily expressed in kg dry matter per animal per day & $\mathrm{kg} / \mathrm{day}$ \\
\hline WF & Fraction of feed that is not consumed & \\
\hline $\mathrm{Zn}_{\text {excreted }}$ & Quantity of zinc excreted during the evaluation period & $\mathrm{kg}$ \\
\hline $\mathrm{Zn}_{\text {intake }}$ & Quantity of zinc consumed by the animal during the evaluation period & $\mathrm{g}$ \\
\hline $\mathrm{Zn}_{\text {product }}$ & $\begin{array}{l}\text { Quantity of zinc stored in the body (tissues and bones) during the evaluation } \\
\text { period }\end{array}$ & $\mathrm{kg}$ \\
\hline $\mathrm{Zn}_{\text {retention }}$ & Quantity of zinc retained in the animal live weight & $\mathrm{kg}$ \\
\hline
\end{tabular}

\subsubsection{Comparison baseline scenario and feed additive scenario}

This subsection provides the relevant equations, taken or adapted from the different animal guidelines, and their modifications linked to the use and effect of a feed additive or a combination of feed additives for the different animal species and categories. In the case of the feed additive scenarios, only those equations for which the results will be modified are indicated.

Table 2 provides definitions of parameters and variables used in all equations for large ruminants, small ruminants, poultry and pigs.

\section{i. Large ruminants for milk production}

\section{Baseline scenario}

Table 3 lists the equations relevant for the evaluation of the environmental impact of milk production from large ruminants for the baseline scenario. The calculated impacts will be the comparison point for the feed additive scenarios. 
Table 3: Equations used for evaluating the baseline emissions for cattle, buffalo and camels used for milk production

\begin{tabular}{|c|c|}
\hline & Basis for calculation \\
\hline Equation LR-1 & $\begin{array}{c}\mathrm{ME}_{\text {intakeother }}(\mathrm{MJ} / \text { day })=\Sigma\left(\text { Total ME requirement }_{\mathrm{d}}-\left(\mathrm{DMI}_{\mathrm{d}} \times \mathrm{ME}_{\mathrm{t}} / \mathrm{kg} \mathrm{DM}\right)_{\text {feed } 1}-\right. \\
\left.\left(\mathrm{DMI}_{\mathrm{d}} \times \mathrm{ME}_{\mathrm{t}} / \mathrm{kg} \mathrm{DM}\right)_{\mathrm{feed} 2}\right)\end{array}$ \\
\hline Equation LR-2 & $\mathrm{DMI}_{\text {other }}(\mathrm{kg} /$ day $)=\mathrm{ME}_{\text {intakeother }} /(\mathrm{ME} / \mathrm{kg} \mathrm{DM})_{\text {other }}$ \\
\hline Equation LR-3 & $\mathrm{GE}(\mathrm{MJ} /$ day $)=\mathrm{DMI} \times 18.45 \mathrm{MJ} / \mathrm{kg} \mathrm{DM}$ \\
\hline Equation LR-4a & $\% \mathrm{~N}$ in feed $(\%)=\% \mathrm{CP} / 6.25$ \\
\hline Equation LR-4b & $\mathrm{N}_{\text {intake }}(\mathrm{kg})=\Sigma\left(\mathrm{DMI}_{\mathrm{d}} \times \% \mathrm{~N}\right.$ in feed $\left.\mathrm{f}_{\mathrm{t}}\right) 100$ \\
\hline Equation LR-5 & $\mathrm{N}_{\text {product }}(\mathrm{kg})=\Sigma\left(\right.$ Milk $_{\mathrm{d}} \times \%$ Protein in milk $\left._{\mathrm{d}} / 100\right) / 6.38$ \\
\hline Equation LR-6 & $\mathrm{P}_{\text {intake }}(\mathrm{kg})=\Sigma\left(\mathrm{DMI}_{\mathrm{d}} \times \% \mathrm{P}_{\text {totalt }} / 100\right)$ \\
\hline Equation LR-7 & $\mathrm{P}_{\text {product }}(\mathrm{kg})=\Sigma\left(\mathrm{Milk}_{\mathrm{d}} \times \% \mathrm{P}\right.$ in milk $\left.\mathrm{d} / 100\right)$ \\
\hline \multirow[t]{3}{*}{ Equation LR-8 } & $\operatorname{VS}(\mathrm{kg} /$ day $)=\mathrm{DMI}_{\mathrm{d}} \times(1.04-\mathrm{DMD}) \times 0.92$ \\
\hline & Calculated impacts \\
\hline & Total \\
\hline Equation LR-9 & $\mathrm{N}_{\text {excreted }}(\mathrm{kg})=\mathrm{N}_{\text {intake }}-\mathrm{N}_{\text {product }}$ \\
\hline Equation LR-10 & $\mathrm{P}_{\text {excreted }}(\mathrm{kg})=\mathrm{P}_{\text {intake }}-\mathrm{P}_{\text {product }}$ \\
\hline Equation LR-11 & $\mathrm{CH}_{4 \text { enteric }}(\mathrm{kg})=\Sigma\left(\mathrm{GE}_{\mathrm{d}} \times \mathrm{EF}_{\mathrm{d}} / 55.65\right)$ \\
\hline Equation LR-12 & $\mathrm{CH}_{4 \text { manure }}(\mathrm{kg})=\Sigma\left(\mathrm{VS}_{\mathrm{d}} \times \mathrm{Bo} \times \mathrm{MCF}_{\mathrm{d}}\right) \times 0.67$ \\
\hline \multirow[t]{2}{*}{ Equation LR-13 } & $\mathrm{N}_{2} \mathrm{O}_{\text {manure }}($ refer to FAO, 2016b, Figure 14) \\
\hline & Intensity \\
\hline Equation LR-14 & $\mathrm{N}_{\text {excreted }}$ Intensity $(\mathrm{kg} / \mathrm{kg} \mathrm{ECM})=\mathrm{N}_{\text {excreted }} / \mathrm{ECM}$ \\
\hline Equation LR-15 & $\mathrm{P}_{\text {excreted }}$ Intensity $(\mathrm{kg} / \mathrm{kg} \mathrm{ECM})=\mathrm{P}_{\text {excreted }} / \mathrm{ECM}$ \\
\hline Equation LR-16 & $\mathrm{CH}_{4 \text { enteric }}$ Intensity $(\mathrm{kg} / \mathrm{kg} \mathrm{ECM})=\mathrm{CH}_{4 \text { enteric }} / \mathrm{ECM}$ \\
\hline Equation LR-17 & $\mathrm{CH}_{4 \text { manure }}$ Intensity $(\mathrm{kg} / \mathrm{kg} \mathrm{ECM})=\mathrm{CH}_{4 \text { manure }} / \mathrm{ECM}$ \\
\hline Equation LR-18 & $\mathrm{N}_{2} \mathrm{O}_{\text {manure }}$ Intensity $(\mathrm{kg} / \mathrm{kg} \mathrm{ECM})=\mathrm{N}_{2} \mathrm{O}_{\text {manure }} / \mathrm{ECM}$ \\
\hline
\end{tabular}

Note: Definitions and units are given in Table 2. Subscript $\mathrm{t}$ is a reference to the type of feed used and subscript $\mathrm{d}$ is a reference to the day (e.g. $\mathrm{ME}_{\mathrm{t}}$ is the metabolizable energy of the type of feed such as a production concentrate and $\mathrm{DMI}_{\mathrm{d}}$ is the dry matter intake of that type of feed on a given day).

\section{Feed additive scenarios}

Tables 4-8 provide the changes in the equations linked to the effect of the feed additives or a combination of feed additives on the response variables. Each table provides information on the following potential effects of the feed additives or the combinations of feed additives (as described in subsection 6.10.3 [i-iii]):

- modification of feed composition $\left(\Phi_{\mathrm{nc}}\right)$ (Table 4)

- feed efficiency (Tables 5, 6 and 7)

- emission factors (Table 8)

When the change in the equations used as a basis for the calculation (upper part of the tables) modifies the calculated impact, the corresponding equations are also indicated (lower part of the tables). As an example, when the concentration of nitrogen is changed in the diet (use of the factor $\Phi_{n c}$ ), the result of both the $\mathrm{N}_{\text {intake }}$ and the $\mathrm{N}_{\text {excreted }}$ is modified; hence, these equations are also indicated. It should be noted that the factor might be different for the changes observed (e.g. $\Phi_{\text {nc }}$ can be 1.05 for change in protein concentration and 0.98 for change in phosphorus concentration). 
Table 4: Adaptation of equations for cattle, buffalo and camels used for milk production (change in feed composition)

\begin{tabular}{lc} 
Equation LR-4a & Basis for calculation \\
\hline Equation LR-4b & N in feed $\left(\Phi_{\mathrm{nc}}\right)(\%)=\% \mathrm{CP} \times \Phi_{\mathrm{nc}} / 6.25$ \\
\hline Equation LR-5 & $\mathrm{N}_{\text {intake }}\left(\Phi_{\mathrm{nc}}\right)(\mathrm{kg})=\Sigma\left(\mathrm{DMI}_{\mathrm{d}} \times \% \mathrm{~N}\right.$ in feed $\left.\mathrm{t}\right) / 100$ \\
\hline & $\mathrm{P}_{\text {intake }}\left(\Phi_{\mathrm{nc}}\right)(\mathrm{kg})=\Sigma\left(\mathrm{DMI}_{\mathrm{d}} \times \% \mathrm{P}_{\text {total }} \times \Phi_{\mathrm{nc}}\right) / 100$ \\
Calculated impacts \\
\hline Equation LR-9 & Total \\
\hline Equation LR-10 & $\mathrm{N}_{\text {excreted }}\left(\Phi_{\mathrm{nc}}\right)(\mathrm{kg})=\mathrm{N}_{\text {intake }}\left(\Phi_{\mathrm{nc}}\right)-\mathrm{N}_{\text {product }}$ \\
\hline Equation LR-13 & $\mathrm{P}_{\text {excreted }}\left(\Phi_{\mathrm{nc}}\right)(\mathrm{kg})=\mathrm{P}_{\text {intake }}\left(\Phi_{\mathrm{nc}}\right)-\mathrm{P}_{\text {product }}$ \\
\hline Equation LR-14 & $\mathrm{N}_{2} \mathrm{O}_{\text {manure }}(\mathrm{refer}$ to FAO, $2016 \mathrm{~b}$, Figure 14$)$ \\
\hline Equation LR-15 & $\mathrm{Intensity}$ \\
\hline
\end{tabular}

Note: $\Phi_{\mathrm{nc}}=$ change in feed composition (protein and phosphorus content); subscript $\mathrm{t}$ is a reference to the type of feed used and subscript $d$ is a reference to the day (e.g. $D I_{d}$ is the dry matter intake of that type of feed on a given day).

When a feed additive or combination of feed additives modifies the feed efficiency of large ruminants for milk production, it could be through modification of one or more of the following:

- feed intake $\left(\Phi_{\mathrm{fi}}\right)$ (Table 5)

- milk production $\left(\Phi_{\mathrm{mp}}\right)$ (Table 6)

- milk composition $\left(\Phi_{\mathrm{mc}}\right)$ (Table 7$)$

If the feed additive or the combination of feed additives has an impact on more than one of the above-mentioned response variables, it is advised to combine the different impacts accordingly. For example, if the feed additive or combination of feed additives modifies feed intake $\left(\Phi_{\mathrm{fi}}\right)$ and milk production $\left(\Phi_{\mathrm{mp}}\right)$, the nitrogen balance will be recalculated as follows:

- $\mathrm{N}_{\text {intake }}\left(\Phi_{\mathrm{fi}}\right)(\mathrm{kg})=\mathrm{DMI} \times \Phi_{\mathrm{fi}} \times \% \mathrm{~N}$ in feed/100 (Equation LR-4b adapted)

- $\mathrm{N}_{\text {product }}\left(\Phi_{\mathrm{mp}}\right)(\mathrm{kg})=$ Milk $\times \Phi_{\mathrm{mp}} \times \%$ Protein in milk/6.38 (Equation LR-7 adapted)

This will lead to a modification of the nitrogen excretion.

Table 5: Adaptation of equations for cattle, buffalo and camels used for milk production (change in feed intake)

\begin{tabular}{|c|c|}
\hline & Basis for calculation \\
\hline Equation LR-1 & $\begin{aligned} \mathrm{ME}_{\text {intakeother }}\left(\Phi_{\mathrm{fi}}\right)(\mathrm{MJ})=\Sigma\left(\text { Total ME requirement }_{\mathrm{d}}-\left(\mathrm{DMI}_{\mathrm{d}} \times \Phi_{\mathrm{fi}} \times \mathrm{ME}_{\mathrm{t}} / \mathrm{kg} \mathrm{DM}\right)_{\text {feed } 1}-\right. \\
\left.\left(\mathrm{DMI}_{\mathrm{d}} \times \Phi_{\mathrm{fi}} \times \mathrm{ME}_{\mathrm{t}} / \mathrm{kg} \mathrm{DM}\right)_{\text {feed2 }}\right)\end{aligned}$ \\
\hline Equation LR-2 & $\mathrm{DMI}_{\text {other }}\left(\Phi_{\mathrm{fi}}\right)(\mathrm{kg})=\mathrm{ME}_{\text {intakeother }}\left(\Phi_{\mathrm{fi}}\right) /(\mathrm{ME} / \mathrm{kg} \mathrm{DM})$ \\
\hline Equation LR-3 & $\mathrm{GE}\left(\Phi_{\mathrm{fi}}\right)(\mathrm{MJ})=\mathrm{DMI} \times \Phi_{\mathrm{fi}} \times 18.45$ \\
\hline Equation LR-4a & $\% \mathrm{~N}$ in feed $(\%)=\% \mathrm{CP} / 6.25$ \\
\hline Equation LR-4b & $\mathrm{N}_{\text {intake }}\left(\Phi_{\mathrm{fi}}\right)(\mathrm{kg})=\mathrm{DMI} \times \Phi_{\mathrm{fi}} \times \% \mathrm{~N}$ in feed $/ 100$ \\
\hline Equation LR-5 & $\mathrm{P}_{\text {intake }}\left(\Phi_{\mathrm{fi}}\right)(\mathrm{kg})=\mathrm{DMI} \times \Phi_{\mathrm{fi}} \times \% \mathrm{P}_{\text {total }} / 100$ \\
\hline Equation LR-8 & $\operatorname{VS}\left(\Phi_{\mathrm{fi}}\right)(\mathrm{kg} /$ day $)=\mathrm{DMI} \times \Phi_{\mathrm{fi}} \times(1.04-\mathrm{DMD}) \times 0.92$ \\
\hline
\end{tabular}




\begin{tabular}{|c|c|}
\hline & Calculated impacts \\
\hline & Total \\
\hline Equation LR-9 & $\mathrm{N}_{\text {excreted }}\left(\Phi_{\mathrm{fi}}\right)(\mathrm{kg})=\mathrm{N}_{\text {intake }}\left(\Phi_{\mathrm{fi}}\right)-\mathrm{N}_{\text {product }}$ \\
\hline Equation LR-10 & $\mathrm{P}_{\text {excreted }}\left(\Phi_{\mathrm{fi}}\right)(\mathrm{kg})=\mathrm{P}_{\text {intake }}\left(\Phi_{\mathrm{fi}}\right)-\mathrm{P}_{\text {product }}$ \\
\hline Equation LR-11 & $\mathrm{CH}_{4 \text { enteric }}\left(\Phi_{\mathrm{fi}}\right)(\mathrm{kg})=\mathrm{GE}\left(\Phi_{\mathrm{fi}}\right) \times \mathrm{EF} / 55.65$ \\
\hline Equation LR-12 & $\mathrm{CH}_{4 \text { manure }}\left(\Phi_{\mathrm{fi}}\right)(\mathrm{kg})=\Sigma\left(\mathrm{VS}_{\mathrm{d}}\left(\Phi_{\mathrm{fi}}\right) \times \mathrm{Bo} \times \mathrm{MCF}_{\mathrm{d}}\right) \times 0.67$ \\
\hline Equation LR-13 & $\mathrm{N}_{2} \mathrm{O}_{\text {manure }}\left(\Phi_{\mathrm{fi}}\right)($ refer to FAO, 2016b, Figure 14) \\
\hline & Intensity \\
\hline Equation LR-14 & $\mathrm{N}_{\text {excreted }}$ Intensity $(\mathrm{kg} / \mathrm{kg} \mathrm{ECM})=\mathrm{N}_{\text {excreted }}\left(\Phi_{\mathrm{f}}\right) / \mathrm{ECM}$ \\
\hline Equation LR-15 & $\mathrm{P}_{\text {excreted }}$ Intensity $(\mathrm{kg} / \mathrm{kg} \mathrm{ECM})=\mathrm{P}_{\text {excreted }}\left(\Phi_{\mathrm{fi}}\right) / \mathrm{ECM}$ \\
\hline Equation LR-16 & $\mathrm{CH}_{4 \text { enteric }}$ Intensity $(\mathrm{kg} / \mathrm{kg} \mathrm{ECM})=\mathrm{CH}_{4 \text { enteric }}\left(\Phi_{\mathrm{fi}}\right) / \mathrm{ECM}$ \\
\hline Equation LR-17 & $\mathrm{CH}_{4 \text { manure }}$ Intensity $(\mathrm{kg} / \mathrm{kg} \mathrm{ECM})=\mathrm{CH}_{4 \text { manure }}\left(\Phi_{\mathrm{fi}}\right) / \mathrm{ECM}$ \\
\hline Equation LR-18 & $\mathrm{N}_{2} \mathrm{O}_{\text {manure }}$ Intensity $(\mathrm{kg} / \mathrm{kg} \mathrm{ECM})=\mathrm{N}_{2} \mathrm{O}_{\text {manure }}\left(\Phi_{\mathrm{fi}}\right) / \mathrm{ECM}$ \\
\hline
\end{tabular}

Note: $\Phi_{\mathrm{fi}}=$ change in feed intake; subscript $\mathrm{t}$ is a reference to the type of feed used and subscript $\mathrm{d}$ is a reference to the day (e.g. $\mathrm{ME}_{\mathrm{t}}$ is the metabolizable energy of the type of feed such as a production concentrate and $\mathrm{DMI}_{\mathrm{d}}$ is the dry matter intake of that type of feed on a given day).

In the case of modification of the milk production, the ECM is also modified as follows:

$\operatorname{ECM}\left(\Phi_{\mathrm{mp}}\right)=\operatorname{Milk} \times \Phi_{\mathrm{mp}} \times(0.1226 \times \%$ fat $+0.0776 \times \%$ true protein +0.2534$)$

Hence the emission intensity is modified.

Table 6: Adaptation of equations for cattle, buffalo and camels used for milk production (change in milk production)

\begin{tabular}{|c|c|}
\hline & Basis for calculation \\
\hline Equation LR-6 & $\mathrm{N}_{\text {product }}\left(\Phi_{\mathrm{mp}}\right)(\mathrm{kg})=\Sigma\left(\right.$ Milk $_{\mathrm{d}} \times \Phi_{\mathrm{mp}} \times \%$ Protein in milk $\left.\mathrm{d}_{\mathrm{d}} / 100\right) / 6.38$ \\
\hline \multirow[t]{3}{*}{ Equation LR-7 } & $\mathrm{P}_{\text {product }}\left(\Phi_{\mathrm{mp}}\right)(\mathrm{kg})=\Sigma\left(\mathrm{Milk}_{\mathrm{d}} \times \Phi_{\mathrm{mp}} \times \% \mathrm{P}\right.$ in milk $\left./ 100\right)$ \\
\hline & Calculated impacts \\
\hline & Total \\
\hline Equation LR-9 & $\mathrm{N}_{\text {excreted }}\left(\Phi_{\mathrm{mp}}\right)(\mathrm{kg})=\mathrm{N}_{\text {intake }}-\mathrm{N}_{\text {product }}\left(\Phi_{\mathrm{mp}}\right)$ \\
\hline \multirow[t]{2}{*}{ Equation LR-10 } & $\mathrm{P}_{\text {excreted }}\left(\Phi_{\mathrm{mp}}\right)(\mathrm{kg})=\mathrm{P}_{\text {intake }}-\mathrm{P}_{\text {product }}\left(\Phi_{\mathrm{mp}}\right)$ \\
\hline & Intensity \\
\hline Equation LR-14 & $\mathrm{N}_{\text {excreted }}$ Intensity $\left(\Phi_{\mathrm{mp}}\right)(\mathrm{kg} / \mathrm{kg}$ ECM $)=\mathrm{N}_{\text {excreted }}\left(\Phi_{\mathrm{mp}}\right) / \mathrm{ECM}\left(\Phi_{\mathrm{mp}}\right)$ \\
\hline Equation LR-15 & $\mathrm{P}_{\text {excreted }}$ Intensity $\left(\Phi_{\mathrm{mp}}\right)(\mathrm{kg} / \mathrm{kg} \mathrm{ECM})=\mathrm{P}_{\text {excreted }}\left(\Phi_{\mathrm{mp}}\right) / \mathrm{ECM}\left(\Phi_{\mathrm{mp}}\right)$ \\
\hline Equation LR-16 & $\mathrm{CH}_{4 \text { enteric }}$ Intensity $\left(\Phi_{\mathrm{mp}}\right)(\mathrm{kg} / \mathrm{kg} \mathrm{ECM})=\mathrm{CH}_{4 \text { enteric }} / \mathrm{ECM}\left(\Phi_{\mathrm{mp}}\right)$ \\
\hline Equation LR-17 & $\mathrm{CH}_{4 \text { manure }}$ Intensity $\left(\Phi_{\mathrm{mp}}\right)(\mathrm{kg} / \mathrm{kg} \mathrm{ECM})=\mathrm{CH}_{4 \text { manure }} / \mathrm{ECM}\left(\Phi_{\mathrm{mp}}\right)$ \\
\hline Equation LR-18 & $\mathrm{N}_{2} \mathrm{O}_{\text {manure }}$ Intensity $\left(\Phi_{\mathrm{mp}}\right)(\mathrm{kg} / \mathrm{kg} \mathrm{ECM})=\mathrm{N}_{2} \mathrm{O}_{\text {manure }} / \mathrm{ECM}\left(\Phi_{\mathrm{mp}}\right)$ \\
\hline
\end{tabular}

When the feed additive or the combination of feed additives modifies milk composition, the factor $\Phi_{\mathrm{mc}}$ is used in the equations (Table 7). It should be noted that the factor might be different for the changes observed (e.g. $\Phi_{\mathrm{mc}}$ can be 1.05 for a change in protein concentration and 0.98 for a change in fat concentration). The modification of milk composition has an impact on the ECM, as described below:

$\operatorname{ECM}\left(\Phi_{\mathrm{mc}}\right)=\operatorname{Milk} \times\left(0.1226 \times \%\right.$ fat $\times \Phi_{\mathrm{mc}}+0.0776 \times \%$ true protein $\left.\times \Phi_{\mathrm{mc}}+0.2534\right)$

Hence the emission intensity is modified. 
Table 7: Adaptation of equations for cattle, buffalo and camels used for milk production (change in milk composition)

\begin{tabular}{|c|c|}
\hline & Basis for calculation \\
\hline Equation LR-6 & $\mathrm{N}_{\text {product }}\left(\Phi_{\mathrm{mc}}\right)(\mathrm{kg})=\Sigma\left(\mathrm{Milk}_{\mathrm{d}} \times \%\right.$ Protein in milk $\left.\mathrm{d} \times \Phi_{\mathrm{mc}} / 100\right) / 6.38$ \\
\hline \multirow{3}{*}{ Equation LR-7 } & $\mathrm{P}_{\text {product }}\left(\Phi_{\mathrm{mc}}\right)(\mathrm{kg})=\Sigma\left(\mathrm{Milk}_{\mathrm{d}} \times \% \mathrm{P}\right.$ in milk $\left._{\mathrm{d}} \times \Phi_{\mathrm{mc}}\right) / 100$ \\
\hline & Calculated impacts \\
\hline & Total \\
\hline Equation LR-9 & $\mathrm{N}_{\text {excreted }}\left(\Phi_{\mathrm{mc}}\right)(\mathrm{kg})=\mathrm{N}_{\text {intake }}-\mathrm{N}_{\text {product }}\left(\Phi_{\mathrm{mc}}\right)$ \\
\hline \multirow[t]{2}{*}{ Equation LR-10 } & $\mathrm{P}_{\text {excreted }}\left(\Phi_{\mathrm{mc}}\right)(\mathrm{kg})=\mathrm{P}_{\text {intake }}-\mathrm{P}_{\text {product }}\left(\Phi_{\mathrm{mc}}\right)$ \\
\hline & Intensity \\
\hline Equation LR-14 & $\mathrm{N}_{\text {excreted }}$ Intensity $\left(\Phi_{\mathrm{mc}}\right)(\mathrm{kg} / \mathrm{kg} \mathrm{ECM})=\mathrm{N}_{\text {excreted }}\left(\Phi_{\mathrm{mc}}\right) / \mathrm{ECM}\left(\Phi_{\mathrm{mc}}\right)$ \\
\hline Equation LR-15 & $\mathrm{P}_{\text {excreted }}$ Intensity $\left(\Phi_{\mathrm{mc}}\right)(\mathrm{kg} / \mathrm{kg} \mathrm{ECM})=\mathrm{P}_{\text {excreted }}\left(\Phi_{\mathrm{mc}}\right) / \mathrm{ECM}\left(\Phi_{\mathrm{mc}}\right)$ \\
\hline Equation LR-16 & $\mathrm{CH}_{\text {enteric }}$ Intensity $\left(\Phi_{\mathrm{mc}}\right)(\mathrm{kg} / \mathrm{kg} \mathrm{ECM})=\mathrm{CH}_{4 \text { enteric }} / \mathrm{ECM}\left(\Phi_{\mathrm{mc}}\right)$ \\
\hline Equation LR-17 & $\mathrm{CH}_{4 \text { manure }}$ Intensity $\left(\Phi_{\mathrm{mc}}\right)(\mathrm{kg} / \mathrm{kg} \mathrm{ECM})=\mathrm{CH}_{4 \text { manure }} / \mathrm{ECM}\left(\Phi_{\mathrm{mc}}\right)$ \\
\hline Equation LR-18 & $\mathrm{N}_{2} \mathrm{O}_{\text {manure }}$ Intensity $\left(\Phi_{\mathrm{mc}}\right)(\mathrm{kg} / \mathrm{kg} \mathrm{ECM})=\mathrm{N}_{2} \mathrm{O}_{\text {manure }} / \mathrm{ECM}\left(\Phi_{\mathrm{mc}}\right)$ \\
\hline
\end{tabular}

Note: $\Phi_{\mathrm{mc}}=$ change in milk composition; subscript $\mathrm{d}$ is a reference to the day (e.g. Milk $\mathrm{d}_{\mathrm{d}}$ is the milk production on a given day).

When the feed additive or the combination has a direct effect on methane $\left(\mathrm{CH}_{4}\right)$ or nitrous oxide $\left(\mathrm{N}_{2} \mathrm{O}\right)$ emissions, the factor $\Phi_{\mathrm{ef}}$ is used for the modification of the emission factor in the relevant equations. Although the factor is named in the same way in the equations $\left(\Phi_{\mathrm{ef}}\right)$, it will differ for the relevant emissions.

Table 8: Adaptation of equations for cattle, buffalo and camels used for milk production (change in emission factor)

\begin{tabular}{|c|c|}
\hline & Calculated impacts \\
\hline & Total \\
\hline Equation 11 & $\mathrm{CH}_{4 \text { enteric }}\left(\Phi_{\mathrm{ef}}\right)(\mathrm{kg})=\Sigma\left(\mathrm{GE}_{\mathrm{d}} \times \mathrm{EF} \times \Phi_{\mathrm{ef}} / 55.65\right)$ \\
\hline Equation 12 & $\mathrm{CH}_{4 \text { manure }}\left(\Phi_{\mathrm{ef}}\right)(\mathrm{kg})=\Sigma\left(\mathrm{VS}_{\mathrm{d}} \times \mathrm{Bo} \times \mathrm{MCF} \times \Phi_{\mathrm{ef}} \times 0.67\right)$ \\
\hline \multirow[t]{2}{*}{ Equation 13} & $\mathrm{~N}_{2} \mathrm{O}_{\text {manure }}\left(\Phi_{\mathrm{ef}}\right)($ refer to FAO, 2016b, Figure 14) \\
\hline & Intensity \\
\hline Equation LR-16 & $\mathrm{CH}_{4 \text { enteric }}$ Intensity $\left(\Phi_{\mathrm{ef}}\right)(\mathrm{kg} / \mathrm{kg} \mathrm{ECM})=\mathrm{CH}_{4 \text { enteric }}\left(\Phi_{\mathrm{ef}}\right) / \mathrm{ECM}$ \\
\hline Equation LR-17 & $\mathrm{CH}_{4 \text { manure }}$ Intensity $\left(\Phi_{\mathrm{ef}}\right)(\mathrm{kg} / \mathrm{kg} \mathrm{ECM})=\mathrm{CH}_{4 \text { manure }}\left(\Phi_{\mathrm{ef}}\right) / \mathrm{ECM}$ \\
\hline Equation LR-18 & $\mathrm{N}_{2} \mathrm{O}_{\text {manure }}$ Intensity $\left(\Phi_{\mathrm{ef}}\right)(\mathrm{kg} / \mathrm{kg} \mathrm{ECM})=\mathrm{N}_{2} \mathrm{O}_{\text {manure }}\left(\Phi_{\mathrm{ef}}\right) / \mathrm{ECM}$ \\
\hline
\end{tabular}

Note: $\Phi_{\text {ef }}=$ change in emission factor; subscript $d$ is a reference to the day (e.g. $\mathrm{GE}_{\mathrm{d}}$ is the gross energy intake on a given day).

\section{ii. Other large ruminants}

\section{Baseline scenario}

Table 9 lists the equations relevant for the evaluation of the environmental impact of large ruminants such as growing cattle (replacement heifers, beef cattle) and cattle, buffalo and camels used for suckling purposes for the baseline scenario. The calculated impacts will be the comparison point for the feed additive scenario. Definitions of parameters and variables used in the equations are given in Table 2. 
Table 9: Equations used for evaluating the baseline emissions for growing cattle (replacement heifers, beef cattle) and cattle, buffalo and camels used for suckling purposes

\begin{tabular}{|c|c|}
\hline & Basis for calculation \\
\hline Equation LR-1 & $\begin{array}{c}\mathrm{ME}_{\text {intakeother }}(\mathrm{MJ})=\Sigma\left(\text { Total ME requirement } \mathrm{d}_{\mathrm{d}}-\left(\mathrm{DMI}_{\mathrm{d}} \times \mathrm{ME} / \mathrm{kg} \mathrm{DM}\right)_{\mathrm{feed} 1}-\right. \\
\left.\left(\mathrm{DMI}_{\mathrm{d}} \times \mathrm{ME} / \mathrm{kg} \mathrm{DM}\right)_{\mathrm{feed} 2}\right)\end{array}$ \\
\hline Equation LR-2 & $\mathrm{DMI}_{\text {other }}(\mathrm{kg})=\mathrm{ME}_{\text {intakeother }} /(\mathrm{ME} / \mathrm{kg} \mathrm{DM})$ \\
\hline Equation LR-3 & $\mathrm{GE}(\mathrm{MJ})=\Sigma\left(\mathrm{DMI}_{\mathrm{d}} \times 18.45\right)$ \\
\hline Equation LR-4a & $\% \mathrm{~N}$ in feed $(\%)=\% \mathrm{CP} / 6.25$ \\
\hline Equation LR-4b & $\mathrm{N}_{\text {intake }}(\mathrm{kg})=\Sigma\left(\mathrm{DMI}_{\mathrm{d}} \times \% \mathrm{~N}\right.$ in feed $\left.\mathrm{d}_{\mathrm{t}}\right) / 100$ \\
\hline Equation LR-5 & $\mathrm{P}_{\text {intake }}(\mathrm{kg})=\Sigma\left(\mathrm{DMI}_{\mathrm{d}} \times \% \mathrm{P}_{\text {totalt }}\right) / 100$ \\
\hline Equation LR-6 & $\mathrm{N}_{\text {product }}(\mathrm{kg})=\mathrm{TWG} \times \%$ Protein in tissues $/ 100 / 6.25$ \\
\hline Equation LR-7 & $\mathrm{P}_{\text {product }}(\mathrm{kg})=\mathrm{TWG} \times \% \mathrm{P}$ in tissues and bones $/ 100$ \\
\hline \multirow[t]{3}{*}{ Equation LR-8 } & $\mathrm{VS}(\mathrm{kg} /$ day $)=\mathrm{DMI}_{\mathrm{d}} \times(1.04-\mathrm{DMD}) \times 0.92$ \\
\hline & Calculated impacts \\
\hline & Total \\
\hline Equation LR-9 & $\mathrm{N}_{\text {excreted }}(\mathrm{kg})=\mathrm{N}_{\text {intake }}-\mathrm{N}_{\text {product }}$ \\
\hline Equation LR-10 & $\mathrm{P}_{\text {excreted }}(\mathrm{kg})=\mathrm{P}_{\text {intake }}-\mathrm{P}_{\text {product }}$ \\
\hline Equation LR-11 & $\mathrm{CH}_{4 \text { enteric }}(\mathrm{kg})=\Sigma\left(\mathrm{GE}_{\mathrm{d}} \times \mathrm{EF}\right) / 55.65$ \\
\hline Equation LR-12 & $\mathrm{CH}_{4 \text { manure }}(\mathrm{kg})=\Sigma\left(\mathrm{VS}_{\mathrm{d}} \times \mathrm{Bo} \times \mathrm{MCF}_{\mathrm{d}}\right) \times 0.67$ \\
\hline \multirow[t]{2}{*}{ Equation LR-13 } & $\mathrm{N}_{2} \mathrm{O}_{\text {manure }}($ refer to FAO, 2016b, Figure 14) \\
\hline & Intensity \\
\hline Equation LR-14 & $\mathrm{N}_{\text {excreted }}$ Intensity $(\mathrm{kg} / \mathrm{kg}$ live weight $)=\mathrm{N}_{\text {excreted }} / \mathrm{TWG}$ \\
\hline Equation LR-15 & $\mathrm{P}_{\text {excreted }}$ Intensity $(\mathrm{kg} / \mathrm{kg}$ live weight $)=\mathrm{P}_{\text {excreted }} / \mathrm{TWG}$ \\
\hline Equation LR-16 & $\mathrm{CH}_{4 \text { enteric }}$ Intensity $(\mathrm{kg} / \mathrm{kg}$ live weight $)=\mathrm{CH}_{4 \text { enteric }} / \mathrm{TWG}$ \\
\hline Equation LR-17 & $\mathrm{CH}_{4 \text { manure }}$ Intensity $(\mathrm{kg} / \mathrm{kg}$ live weight $)=\mathrm{CH}_{4 \text { manure }} / \mathrm{TWG}$ \\
\hline Equation LR-18 & $\mathrm{N}_{2} \mathrm{O}_{\text {manure }}$ Intensity $(\mathrm{kg} / \mathrm{kg}$ live weight $)=\mathrm{N}_{2} \mathrm{O}_{\text {manure }} / \mathrm{TWG}$ \\
\hline
\end{tabular}

Note: Subscript $t$ is a reference to the type of feed used and subscript $d$ is a reference to the day (e.g. $D_{M I}$ is the dry matter intake of that type of feed on a given day).

\section{Feed additive scenarios}

Tables 10-14 provide the changes in the equations linked to the effect of the feed additives or a combination of feed additives on the parameters. Each table provides information on the following potential effects of the feed additives or the combinations of feed additives, as described in subsection 6.10 .3 (i-iii):

- modification of feed composition $\left(\Phi_{\text {nc }}\right)($ Table 10$)$

- feed efficiency (Tables 11, 12, 13)

- emission factors (Table 14)

When the change in the equations used as a basis for the calculation (upper part of the tables) modifies the calculated impact, the corresponding equations are also indicated (lower part of the tables). As an example, when the concentration of nitrogen is changed in the diet (use of the factor $\Phi_{\text {nc }}$ ), the result of both the $N_{\text {intake }}$ and the $\mathrm{N}_{\text {excreted }}$ is changed. Hence these equations are also indicated. It should be noted that the factor might be different for the changes observed (e.g. $\Phi_{\text {nc }}$ can be 1.05 for change in protein concentration and 0.98 for change in phosphorus concentration). 
Table 10: Adaptation of equations for growing cattle (replacement heifers, beef cattle) and cattle, buffalo and camels used for suckling purposes (change in feed composition)

\begin{tabular}{|c|c|}
\hline & Basis for calculation \\
\hline Equation LR-4a & $\% \mathrm{~N}$ in feed $\left(\Phi_{\mathrm{nc}}\right)(\%)=\% \mathrm{CP} \times \Phi_{\mathrm{nc}} / 6.25$ \\
\hline Equation LR-4b & $\mathrm{N}_{\text {intake }}\left(\Phi_{\mathrm{nc}}\right)(\mathrm{kg})=\Sigma\left(\mathrm{DMI}_{\mathrm{d}} \times \% \mathrm{~N}\right.$ in feed $\left.\mathrm{t}\left(\Phi_{\mathrm{nc}}\right) / 100\right) / 6.25$ \\
\hline \multirow[t]{3}{*}{ Equation LR-5 } & $\mathrm{P}_{\text {intake }}\left(\Phi_{\mathrm{nc}}\right)(\mathrm{kg})=\Sigma\left(\mathrm{DMI}_{\mathrm{d}} \times \% \mathrm{P}_{\text {totalt }} \times \Phi_{\mathrm{nc}}\right) / 100$ \\
\hline & Calculated impacts \\
\hline & Total \\
\hline Equation LR-9 & $\mathrm{N}_{\text {excreted }}\left(\Phi_{\mathrm{nc}}\right)(\mathrm{kg})=\mathrm{N}_{\text {intake }}\left(\Phi_{\mathrm{nc}}\right)-\mathrm{N}_{\text {product }}$ \\
\hline \multirow[t]{2}{*}{ Equation LR-10 } & $\mathrm{P}_{\text {excreted }}\left(\Phi_{\text {nc }}\right)(\mathrm{kg})=\mathrm{P}_{\text {intake }}\left(\Phi_{\mathrm{nc}}\right)-\mathrm{P}_{\text {product }}$ \\
\hline & Intensity \\
\hline Equation LR-14 & $\mathrm{N}_{\text {excreted }}$ Intensity $\left(\Phi_{\mathrm{nc}}\right)(\mathrm{kg} / \mathrm{kg}$ live weight $)=\mathrm{N}_{\text {excreted }}\left(\Phi_{\mathrm{nc}}\right) / \mathrm{TWG}$ \\
\hline Equation LR-15 & $\mathrm{P}_{\text {excreted }}$ Intensity $\left(\Phi_{\mathrm{nc}}\right)(\mathrm{kg} / \mathrm{kg}$ live weight $)=\mathrm{P}_{\text {excreted }}\left(\Phi_{\mathrm{nc}}\right) / \mathrm{TWG}$ \\
\hline
\end{tabular}

When a feed additive or combination of feed additives modifies the feed efficiency of other large ruminants, it could be through a modification of one or more of the following:

- feed intake $\left(\Phi_{\mathrm{fi}}\right)($ Table 11$)$

- weight gain $\left(\Phi_{\mathrm{wg}}\right)$ (Table 12)

- modification of the weight gain composition $\left(\Phi_{\mathrm{wgc}}\right)$ (Table 13)

In the case that the feed additive or the combination of feed additives has an impact on more than one of the above-mentioned parameters, it is advised to combine the different impact accordingly. For example, if the feed additive or combination of feed additives modifies the feed intake $\left(\Phi_{\mathrm{fi}}\right)$ and the weight gain $\left(\Phi_{\mathrm{wg}}\right)$, the nitrogen balance will be recalculated as follows:

- $\mathrm{N}_{\text {intake }}\left(\Phi_{\mathrm{fi}}\right)(\mathrm{kg})=\mathrm{DMI} \times \Phi_{\mathrm{fi}} \times \% \mathrm{~N}$ in feed/100 (Equation LR-4b adapted)

- $\mathrm{N}_{\text {product }}\left(\Phi_{\mathrm{wg}}\right)(\mathrm{kg})=\mathrm{TWG} \times \Phi_{\mathrm{wg}} \times \%$ Protein in tissues/6.25 (Equation LR-7 adapted)

This will lead to a modification of the nitrogen excretion.

Table 11: Adaptation of equations for growing cattle (replacement heifers, beef cattle) and cattle, buffalo and camels used for suckling purposes (change in feed intake)

\begin{tabular}{|c|c|}
\hline & Basis for calculation \\
\hline Equation LR-1 & $\begin{aligned} \mathrm{ME}_{\text {intakeother }}\left(\Phi_{\mathrm{fi}}\right)(\mathrm{MJ})= & \Sigma\left(\text { Total ME requirement }_{\mathrm{d}}-\left(\mathrm{DMI}_{\mathrm{d}} \times \Phi_{\mathrm{fi}} \times \mathrm{ME} / \mathrm{g} \mathrm{DM}\right)_{\text {feed } 1}\right. \\
& \left.-\left(\mathrm{DMI}_{\mathrm{d}} \times \Phi_{\mathrm{fi}} \times \mathrm{ME} / \mathrm{kg} \mathrm{DM}\right)_{\mathrm{feed} 2}\right)\end{aligned}$ \\
\hline Equation LR-2 & $\mathrm{DMI}_{\text {other }}\left(\Phi_{\mathrm{fi}}\right)(\mathrm{kg})=\mathrm{ME}_{\text {intakeother }}\left(\Phi_{\mathrm{fi}}\right) / \mathrm{ME} / \mathrm{kg} \mathrm{DM}$ \\
\hline Equation LR-3 & $\mathrm{GE}\left(\Phi_{\mathrm{fi}}\right)(\mathrm{MJ})=\Sigma\left(\mathrm{DMI}_{\mathrm{d}} \times \Phi_{\mathrm{fi}}\right) \times 18.45$ \\
\hline Equation LR-4a & $\% \mathrm{~N}$ in feed $(\%)=\% \mathrm{CP} / 6.25$ \\
\hline Equation LR-4b & $\mathrm{N}_{\text {intake }}\left(\Phi_{\mathrm{fi}}\right)(\mathrm{kg})=\Sigma\left(\mathrm{DMI}_{\mathrm{d}} \times \Phi_{\mathrm{fi}} \times \% \mathrm{~N}\right.$ in feed $\left.\mathrm{t} / 100\right) / 6.25$ \\
\hline Equation LR-5 & $\mathrm{P}_{\text {intake }}\left(\Phi_{\mathrm{fi}}\right)(\mathrm{kg})=\Sigma\left(\mathrm{DMI}_{\mathrm{d}} \times \Phi_{\mathrm{fi}} \times \% \mathrm{P}_{\text {totalt }}\right) / 100$ \\
\hline Equation LR-8 & $\operatorname{VS}\left(\Phi_{\mathrm{fi}}\right)(\mathrm{kg} / \mathrm{day})=\mathrm{DMI}_{\mathrm{d}} \times \Phi_{\mathrm{fi}} \times(1.04-\mathrm{DMD}) \times 0.92$ \\
\hline
\end{tabular}




\section{Calculated impacts}

Total

\begin{tabular}{|c|c|}
\hline Equation LR-9 & $\mathrm{N}_{\text {excreted }}\left(\Phi_{\mathrm{fi}}\right)(\mathrm{kg})=\mathrm{N}_{\text {intake }}\left(\Phi_{\mathrm{fi}}\right)-\mathrm{N}_{\text {product }}$ \\
\hline Equation LR-10 & $\mathrm{P}_{\text {excreted }}\left(\Phi_{\mathrm{fi}}\right)(\mathrm{kg})=\mathrm{P}_{\text {intake }}\left(\Phi_{\mathrm{fi}}\right)-\mathrm{P}_{\text {product }}$ \\
\hline Equation LR-11 & $\mathrm{CH}_{4 \text { enteric }}\left(\Phi_{\mathrm{fi}}\right)(\mathrm{kg})=\mathrm{GE}\left(\Phi_{\mathrm{fi}}\right) \times \mathrm{EF} / 55.65$ \\
\hline Equation LR-12 & $\mathrm{CH}_{4 \text { manure }}\left(\Phi_{\mathrm{fi}}\right)(\mathrm{kg})=\Sigma\left(\mathrm{VS}_{\mathrm{d}}\left(\Phi_{\mathrm{fi}}\right) \times \mathrm{Bo} \times \mathrm{MCF}_{\mathrm{d}}\right) \times 0.67$ \\
\hline \multirow[t]{2}{*}{ Equation LR-13 } & $\mathrm{N}_{2} \mathrm{O}_{\text {manure }}($ refer to FAO, 2016b, Figure 14) \\
\hline & Intensity \\
\hline Equation LR-14 & $\mathrm{N}_{\text {excreted }}$ Intensity $\left(\Phi_{\mathrm{fi}}\right)(\mathrm{kg} / \mathrm{kg}$ live weight $)=\mathrm{N}_{\text {excreted }}\left(\Phi_{\mathrm{fi}}\right) / \mathrm{TWG}$ \\
\hline Equation LR-15 & $\mathrm{P}_{\text {excreted }}$ Intensity $\left(\Phi_{\mathrm{fi}}\right)(\mathrm{kg} / \mathrm{kg}$ live weight $)=\mathrm{P}_{\text {excreted }}\left(\Phi_{\mathrm{fi}}\right) / \mathrm{TWG}$ \\
\hline Equation LR-16 & $\mathrm{CH}_{4 \text { enteric }}$ Intensity $\left(\Phi_{\mathrm{fi}}\right)(\mathrm{kg} / \mathrm{kg}$ live weight $)=\mathrm{CH}_{4 \text { enteric }}\left(\Phi_{\mathrm{fi}}\right) / \mathrm{TWG}$ \\
\hline Equation LR-17 & $\mathrm{CH}_{\text {4manure }}$ Intensity $\left(\Phi_{\mathrm{fi}}\right)(\mathrm{kg} / \mathrm{kg}$ live weight $)=\mathrm{CH}_{\text {4manure }}\left(\Phi_{\mathrm{fi}}\right) / \mathrm{TWG}$ \\
\hline Equation LR-18 & $\mathrm{N}_{2} \mathrm{O}_{\text {manure }}$ Intensity $\left(\Phi_{\mathrm{fi}}\right)(\mathrm{kg} / \mathrm{kg}$ live weight $)=\mathrm{N}_{2} \mathrm{O}_{\text {manure }}\left(\Phi_{\mathrm{fi}}\right) / \mathrm{TWG}$ \\
\hline
\end{tabular}

Note: $\Phi_{\mathrm{fi}}=$ change in feed intake; subscript $\mathrm{t}$ is a reference to the type of feed used and subscript $\mathrm{d}$ is a reference to the day (e.g. $\mathrm{DMI}_{\mathrm{d}}$ is the dry matter intake of that type of feed on a given day).

In the case of a modification of the animal performance, the total weight gain is modified as follows:

TWG $\left(\Phi_{\mathrm{gp}}\right)=\mathrm{TWG} \times \Phi_{\mathrm{gp}}$

Hence the emission intensity is modified.

Table 12: Adaptation of equations for growing cattle (replacement heifers, beef cattle) and cattle, buffalo and camels used for suckling purposes (change in growth performance)

\begin{tabular}{|c|c|}
\hline & Basis for calculation \\
\hline Equation LR-6 & $\mathrm{N}_{\text {product }}\left(\Phi_{\mathrm{gp}}\right)(\mathrm{kg})=\left(\mathrm{TWG} \times \Phi_{\mathrm{gp}} \times \%\right.$ Protein in tissues/100)/6.25 \\
\hline \multirow{3}{*}{ Equation LR-7 } & $\mathrm{P}_{\text {product }}\left(\Phi_{\mathrm{gp}}\right)(\mathrm{kg})=\left(\mathrm{TWG} \times \Phi_{\mathrm{gp}} \times \% \mathrm{P}\right.$ in tissues and bones $) / 100$ \\
\hline & Calculated impacts \\
\hline & Total \\
\hline Equation LR-9 & $\mathrm{N}_{\text {excreted }}\left(\Phi_{\mathrm{gp}}\right)(\mathrm{kg})=\mathrm{N}_{\text {intake }}-\mathrm{N}_{\text {product }}\left(\Phi_{\mathrm{gp}}\right)$ \\
\hline Equation LR-10 & $\mathrm{P}_{\text {excreted }}\left(\Phi_{\mathrm{gp}}\right)(\mathrm{kg})=\mathrm{P}_{\text {intake }}-\mathrm{P}_{\text {product }}\left(\Phi_{\mathrm{gp}}\right)$ \\
\hline \multirow[t]{2}{*}{ Equation LR-13 } & $\mathrm{N}_{2} \mathrm{O}_{\text {manure }}\left(\Phi_{\mathrm{gp}}\right)($ refer to FAO, 2016b, Figure 14) \\
\hline & Intensity \\
\hline Equation LR-14 & $\mathrm{N}_{\text {excreted }}$ Intensity $\left(\Phi_{\mathrm{gp}}\right)(\mathrm{kg} / \mathrm{kg}$ live weight $)=\mathrm{N}_{\text {excreted }}\left(\Phi_{\mathrm{gp}}\right) /\left(\mathrm{TWG} \times \Phi_{\mathrm{gp}}\right)$ \\
\hline Equation LR-15 & $\mathrm{P}_{\text {excreted }}$ Intensity $\left(\Phi_{\mathrm{gp}}\right)(\mathrm{kg} / \mathrm{kg}$ live weight $)=\mathrm{P}_{\text {excreted }}\left(\Phi_{\mathrm{gp}}\right) /\left(\mathrm{TWG} \times \Phi_{\mathrm{gp}}\right)$ \\
\hline Equation LR-16 & $\mathrm{CH}_{\text {4enteric }}$ Intensity $\left(\Phi_{\mathrm{gp}}\right)(\mathrm{kg} / \mathrm{kg}$ live weight $)=\mathrm{CH}_{\text {enteric }} /\left(\mathrm{TWG} \times \Phi_{\mathrm{gp}}\right)$ \\
\hline Equation LR-17 & $\mathrm{CH}_{4 \text { manure }}$ Intensity $\left(\Phi_{\mathrm{gp}}\right)(\mathrm{kg} / \mathrm{kg}$ live weight $)=\mathrm{CH}_{4 \text { manure }} /\left(\mathrm{TWG} \times \Phi_{\mathrm{gp}}\right)$ \\
\hline Equation LR-18 & $\mathrm{N}_{2} \mathrm{O}_{\text {manure }}$ Intensity $\left(\Phi_{\mathrm{gp}}\right)(\mathrm{kg} / \mathrm{kg}$ live weight $)=\mathrm{N}_{2} \mathrm{O}_{\text {manure }}\left(\Phi_{\mathrm{gp}}\right) /\left(\mathrm{TWG} \times \Phi_{\mathrm{gp}}\right)$ \\
\hline
\end{tabular}

Note: $\Phi_{\mathrm{gp}}=$ change in growth performance.

When the feed additive or the combination of feed additives modifies the body weight gain composition, the factor $\Phi_{\mathrm{bwc}}$ is used in the equations (Table 13). It should be noted that the factor might be different for the changes observed (e.g. $\Phi_{\text {bwc }}$ can be 1.05 for change in protein concentration and 0.98 for change in phosphorus concentration). 
Table 13: Adaptation of equations for growing cattle (replacement heifers, beef cattle) and cattle, buffalo and camels used for suckling purposes (change in body weight gain composition)

\begin{tabular}{lc} 
Equation LR-6 & $\mathrm{N}_{\text {produt }}\left(\Phi_{\mathrm{bwc}}\right)(\mathrm{kg})=\left(\mathrm{TWG} \times \%\right.$ Protein in tissues $\left.\times \Phi_{\mathrm{bwc}} / 100\right) / 6.25$ \\
\hline Equation LR-7 & $\mathrm{P}_{\text {product }}\left(\Phi_{\mathrm{bwc}}\right)(\mathrm{kg})=\mathrm{TWG} \times \%$ P in tissues and bones $\times \Phi_{\mathrm{bwc}} / 100$ \\
& Calculated impacts \\
\hline Equation LR-9 & Total \\
\hline Equation LR-10 & $\mathrm{N}_{\text {excreted }}\left(\Phi_{\mathrm{bwc}}\right)(\mathrm{kg})=\mathrm{N}_{\text {intake }}-\mathrm{N}_{\text {product }}\left(\Phi_{\mathrm{bwc}}\right)$ \\
\hline & $\mathrm{P}_{\text {excreted }}\left(\Phi_{\mathrm{bwc}}\right)(\mathrm{kg})=\mathrm{P}_{\text {intake }}-\mathrm{P}_{\text {product }}\left(\Phi_{\mathrm{bwc}}\right)$ \\
\hline Equation LR-14 & Intensity \\
\hline Equation LR-15 & $\mathrm{N}_{\text {excreted }}$ Intensity $\left(\Phi_{\mathrm{bwc}}\right)(\mathrm{kg} / \mathrm{kg}$ live weight $)=\mathrm{N}_{\text {excreted }}\left(\Phi_{\mathrm{bwc}}\right) / \mathrm{TWG}$ \\
\hline
\end{tabular}

Note: $\Phi_{\text {bwc }}=$ change in body weight gain composition.

When the feed additive or the combination has a direct effect on methane $\left(\mathrm{CH}_{4}\right)$ or nitrous oxide $\left(\mathrm{N}_{2} \mathrm{O}\right)$ emissions, the factor $\Phi_{\text {ef }}$ is used for the modification of the emission factor in the relevant equations. Although the factor is named in the same way in the equations $\left(\Phi_{\mathrm{ef}}\right)$, it will differ for the relevant emissions.

Table 14: Adaptation of equations for growing cattle (replacement heifers, beef cattle) and cattle, buffalo and camels used for suckling purposes (change in emission factor)

\begin{tabular}{|c|c|}
\hline & Calculated impacts \\
\hline & Total \\
\hline Equation LR-11 & $\mathrm{CH}_{\text {4enteric }}\left(\Phi_{\mathrm{ef}}\right)(\mathrm{kg})=\mathrm{GE} \times \mathrm{EF}(\%) \times \Phi_{\mathrm{ef}} / 55.65(\mathrm{MJ} / \mathrm{kg})$ \\
\hline Equation LR-12 & $\mathrm{CH}_{4 \text { manure }}\left(\Phi_{\mathrm{ef}}\right)(\mathrm{kg})=\Sigma\left(\mathrm{VS}_{\mathrm{d}} \times \mathrm{Bo} \times \mathrm{MCF}_{\mathrm{d}} \times \Phi_{\mathrm{ef}}\right) \times 0.67$ \\
\hline Equation LR-13 & $\mathrm{N}_{2} \mathrm{O}_{\text {manure }}\left(\Phi_{\mathrm{ef}}\right)($ refer to FAO, 2016b, Figure 14$)$ \\
\hline & Intensity \\
\hline Equation LR-16 & $\mathrm{CH}_{\text {4enteric }}$ Intensity $\left(\Phi_{\mathrm{ef}}\right)(\mathrm{kg} / \mathrm{kg}$ live weight $)=\mathrm{CH}_{\text {4enteric }}\left(\Phi_{\mathrm{ef}}\right) / \mathrm{TWG}$ \\
\hline Equation LR-17 & $\mathrm{CH}_{4 \text { manure }}$ Intensity $\left(\Phi_{\text {ef }}\right)(\mathrm{kg} / \mathrm{kg}$ live weight $)=\mathrm{CH}_{4 \text { manure }}\left(\Phi_{\text {ef }}\right) / \mathrm{TWG}$ \\
\hline Equation LR-18 & $\mathrm{N}_{2} \mathrm{O}_{\text {manure }}$ Intensity $\left(\Phi_{\mathrm{ef}}\right)(\mathrm{kg} / \mathrm{kg}$ live weight $)=\mathrm{N}_{2} \mathrm{O}_{\text {manure }}\left(\Phi_{\mathrm{ef}}\right) / \mathrm{TWG}$ \\
\hline
\end{tabular}

\section{iii. Small ruminants (dairy ewes and goats) \\ Baseline scenario}

Table 15 lists the equations relevant to the evaluation of the environmental impact of dairy ewes and goats for the baseline scenario. The calculated impacts will be the comparison point for the feed additive scenario. Definitions of parameters and variables used in the equations are given in Table 2. 
Table 15: Equations used for evaluating the baseline emissions for dairy ewes and goats

\begin{tabular}{|c|c|}
\hline & Basis for calculation \\
\hline Equation SR-1 & $\begin{array}{c}\mathrm{ME}_{\text {intakeother }}(\mathrm{MJ})=\Sigma\left(\text { Total }_{\mathrm{ME}} \text { requirements }-\left(\mathrm{DMI}_{\mathrm{d}} \times \mathrm{ME}_{\mathrm{t}} / \mathrm{kg} \mathrm{DM}\right)_{\mathrm{feed} 1}-\right. \\
\left.\left(\mathrm{DMI}_{\mathrm{d}} \times \mathrm{ME}_{\mathrm{t}} / \mathrm{kg} \mathrm{DM}\right)_{\mathrm{feed} 2}\right)\end{array}$ \\
\hline Equation SR-2 & $\mathrm{DMI}_{\text {other }}(\mathrm{kg})=\mathrm{ME}_{\text {intakeother }} /(\mathrm{ME} / \mathrm{kg} \mathrm{DM})$ \\
\hline Equation SR-3 & $\operatorname{REG}(\%)=1.164-\left(5.160 \times 10^{3} \times \% \mathrm{DE}\right)+\left(1.038 \times 10^{-5} \times \% \mathrm{DE}^{2}\right)-(37.4 / \% \mathrm{DE})$ \\
\hline Equation SR-4 & $\operatorname{REM}(\%)=1.123-\left(4.092 \times 10^{3} \times \% \mathrm{DE}\right)+\left(1.126 \times 10^{-5} \times \% \mathrm{DE}^{2}\right)-(25.4 / \% \mathrm{DE})$ \\
\hline Equation SR-5 & $\begin{aligned} \mathrm{GE}(\mathrm{MJ} / \text { day })= & \left(\left(\mathrm{NE}_{\text {maintenance }}+\mathrm{NE}_{\text {activity }}+\mathrm{NE}_{\text {lactation }}+\mathrm{NE}_{\text {pregnancy }}\right) / \mathrm{REM}+\right. \\
& \left.\left(\mathrm{NE}_{\text {growth }}+\mathrm{NE}_{\mathrm{wool}}\right) / \mathrm{REG}\right) /(\% \mathrm{DE} / 100)\end{aligned}$ \\
\hline Equation SR-6a & $\% \mathrm{~N}$ in feed $(\%)=\% \mathrm{CP} / 6.25$ \\
\hline Equation SR-6b & $\mathrm{N}_{\text {intake }}(\mathrm{kg})=\Sigma\left(\mathrm{DMI}_{\mathrm{d}} \times \% \mathrm{~N}\right.$ in feed $\left._{\mathrm{t}} / 100\right)$ \\
\hline Equation SR-7 & $\mathrm{N}_{\text {product }}(\mathrm{kg})=\Sigma\left(\mathrm{Milk}_{\mathrm{d}} \times\left(\%\right.\right.$ Protein in milk $\left.\left.\mathrm{d}_{\mathrm{d}} / 100\right) / 6.38\right)$ \\
\hline Equation SR-8 & $\mathrm{P}_{\text {intake }}(\mathrm{kg})=\Sigma\left(\mathrm{DMI}_{\mathrm{d}} \times \% \mathrm{P}_{\text {totalt }} / 100\right)$ \\
\hline Equation SR-9 & $\mathrm{P}_{\text {product }}(\mathrm{kg})=\Sigma\left(\right.$ Milk $_{\mathrm{d}} \times \% \mathrm{P}$ in milk $\left.\mathrm{d}_{\mathrm{d}} / 100\right)$ \\
\hline \multirow[t]{3}{*}{ Equation SR-10 } & $\mathrm{VS}(\mathrm{kg} /$ day $)=\mathrm{DMI} \times(1.04-\mathrm{DMD}) \times 0.92$ \\
\hline & Calculated impacts \\
\hline & Total \\
\hline Equation SR-11 & $\mathrm{N}_{\text {excreted }}(\mathrm{kg})=\mathrm{N}_{\text {intake }}-\mathrm{N}_{\text {product }}$ \\
\hline Equation SR-12 & $\mathrm{P}_{\text {excreted }}(\mathrm{kg})=\mathrm{P}_{\text {intake }}-\mathrm{P}_{\text {product }}$ \\
\hline Equation SR-13 & $\mathrm{CH}_{4 \text { enteric }}(\mathrm{kg})=\Sigma\left(\mathrm{GE}_{\mathrm{d}} \times \mathrm{EF}_{\mathrm{d}} / 55.65\right)$ \\
\hline Equation SR-14 & $\mathrm{CH}_{4 \text { manure }}(\mathrm{kg})=\Sigma\left(\mathrm{VS}_{\mathrm{d}} \times \mathrm{Bo} \times \mathrm{MCF}_{\mathrm{d}} \times 0.67\right)$ \\
\hline \multirow[t]{2}{*}{ Equation SR-15 } & $\mathrm{N}_{2} \mathrm{O}_{\text {manure }}($ refer to FAO, 2016c, Figure 11) \\
\hline & Intensity \\
\hline Equation SR-16 & $\mathrm{N}_{\text {excreted }}$ Intensity $(\mathrm{kg} / \mathrm{kg} \mathrm{ECM})=\mathrm{N}_{\text {excreted }} / \mathrm{ECM}$ \\
\hline Equation SR-17 & $\mathrm{P}_{\text {excreted }}$ Intensity $(\mathrm{kg} / \mathrm{kg} \mathrm{ECM})=\mathrm{P}_{\text {excreted }} / \mathrm{ECM}$ \\
\hline Equation SR-18 & $\mathrm{CH}_{4 \text { enteric }}$ Intensity $(\mathrm{kg} / \mathrm{kg} \mathrm{ECM})=\mathrm{CH}_{4 \text { enteric }} / \mathrm{ECM}$ \\
\hline Equation SR-19 & $\mathrm{CH}_{4 \text { manure }}$ Intensity $(\mathrm{kg} / \mathrm{kg} \mathrm{ECM})=\mathrm{CH}_{4 \operatorname{manur}} / \mathrm{ECM}$ \\
\hline Equation SR-20 & $\mathrm{N}_{2} \mathrm{O}_{\text {manure }}$ Intensity $(\mathrm{kg} / \mathrm{kg} \mathrm{ECM})=\mathrm{N}_{2} \mathrm{O}_{\text {manure }} / \mathrm{ECM}$ \\
\hline
\end{tabular}

\section{Feed additive scenarios}

Tables 16-20 provide the changes in the equations linked to the effect of the feed additives or a combination of feed additives on the parameters. Each table provides information on the following potential effects of the feed additives or the combinations of feed additives, as described in subsection 6.10.3 (i-iii):

- modification of feed composition (Table 16)

- feed efficiency (Tables 17, 18, 19)

- emission factors (Table 20)

When the change in the equations used as a basis for the calculation (upper part of the tables) modifies the calculated impact, the corresponding equations are indicated as well (lower part of the tables). As an example, when the concentration of nitrogen is changed in the diet (use of the factor $\Phi_{\text {nc }}$ ), the result of both the $\mathrm{N}_{\text {intake }}$ and the $\mathrm{N}_{\text {excreted }}$ is changed. Hence these equations are also indicated. It should be noted that the factor might be different for the changes observed (e.g. $\Phi_{\mathrm{nc}}$ can be 1.05 for change in protein concentration and 0.98 for change in phosphorus concentration). 
Table 16: Adaptation of equations for dairy ewes and goats (change in feed composition)

\begin{tabular}{|c|c|}
\hline & Basis for calculation \\
\hline Equation SR-6a & $\% \mathrm{~N}$ in feed $\left(\Phi_{\mathrm{nc}}\right)(\%)=\% \mathrm{CP} \times \Phi_{\mathrm{nc}} / 6.25$ \\
\hline Equation SR-6b & $\mathrm{N}_{\text {intake }}\left(\Phi_{\mathrm{nc}}\right)(\mathrm{kg})=\Sigma\left(\mathrm{DMI}_{\mathrm{d}} \times \% \mathrm{~N}\right.$ in feed $\left.\left(\Phi_{\mathrm{nc}}\right) / 100\right)$ \\
\hline \multirow[t]{3}{*}{ Equation SR-8 } & $\mathrm{P}_{\text {intake }}\left(\Phi_{\mathrm{nc}}\right)(\mathrm{kg})=\Sigma\left(\mathrm{DMI}_{\mathrm{d}} \times \% \mathrm{P}_{\text {totalt }} \times \Phi_{\mathrm{nc}} / 100\right)$ \\
\hline & Calculated impacts \\
\hline & Total \\
\hline Equation SR-11 & $\mathrm{N}_{\text {excreted }}\left(\Phi_{\mathrm{nc}}\right)(\mathrm{kg})=\mathrm{N}_{\text {intake }}\left(\Phi_{\mathrm{nc}}\right)-\mathrm{N}_{\text {product }}$ \\
\hline \multirow[t]{2}{*}{ Equation SR-12 } & $\mathrm{P}_{\text {excreted }}\left(\Phi_{\mathrm{nc}}\right)(\mathrm{kg})=\mathrm{P}_{\text {intake }}\left(\Phi_{\mathrm{nc}}\right)-\mathrm{P}_{\text {product }}$ \\
\hline & Intensity \\
\hline Equation SR-16 & $\mathrm{N}_{\text {excreted }}$ Intensity $\left(\Phi_{\mathrm{nc}}\right)(\mathrm{kg} / \mathrm{kg} \mathrm{ECM})=\mathrm{N}_{\text {excreted }}\left(\Phi_{\mathrm{nc}}\right) / \mathrm{ECM}$ \\
\hline Equation SR-17 & $\mathrm{P}_{\text {excreted }}$ Intensity $\left(\Phi_{\mathrm{nc}}\right)(\mathrm{kg} / \mathrm{kg} \mathrm{ECM})=\mathrm{P}_{\text {excreted }}\left(\Phi_{\mathrm{nc}}\right) / \mathrm{ECM}$ \\
\hline
\end{tabular}

When a feed additive or combination of feed additives modifies the feed efficiency of dairy ewes and goats, it could be through a modification of one or more of the following:

- feed intake $\left(\Phi_{\mathrm{fi}}\right)($ Table 17$)$

- milk production $\left(\Phi_{\mathrm{mp}}\right)$ (Table 18)

- milk composition $\left(\Phi_{\mathrm{mc}}\right)$ (Table 19)

In the case that the feed additive or the combination of feed additives has an impact on more than one of the above-mentioned parameters, it is advised to combine the different impact accordingly. For example, if the feed additive or combination of feed additives modifies the feed intake $\left(\Phi_{\mathrm{fi}}\right)$ and the milk production $\left(\Phi_{\mathrm{mp}}\right)$, the nitrogen balance will be recalculated as follows:

- $\mathrm{N}_{\text {intake }}\left(\Phi_{\mathrm{fi}}\right)(\mathrm{kg})=\mathrm{DMI} \times \Phi_{\mathrm{fi}} \times \% \mathrm{~N}$ in feed/100 (Equation LR-4b adapted)

- $\mathrm{N}_{\text {product }}\left(\Phi_{\mathrm{mp}}\right)(\mathrm{kg})=$ Milk $\times \Phi_{\mathrm{mp}} \times \%$ Protein in milk/6.38 (Equation LR-7 adapted)

This will lead to a modification of the nitrogen excretion.

Table 17: Adaptation of equations for dairy ewes and goats (change in feed intake)

\begin{tabular}{|c|c|}
\hline & Basis for calculation \\
\hline Equation SR-1 & 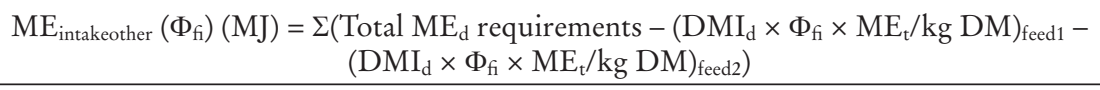 \\
\hline Equation SR-2 & $\mathrm{DMI}_{\text {other }}\left(\Phi_{\mathrm{fi}}\right)(\mathrm{kg} /$ day $)=\mathrm{ME}_{\text {intakeother }}\left(\Phi_{\mathrm{fi}}\right) /(\mathrm{ME} / \mathrm{kg} \mathrm{DM})$ \\
\hline Equation SR-6b & $\mathrm{N}_{\text {intake }}\left(\Phi_{\mathrm{fi}}\right)(\mathrm{kg})=\Sigma\left(\mathrm{DMI}_{\mathrm{d}} \times \Phi_{\mathrm{fi}} \times \% \mathrm{~N}\right.$ in feed $\left./ 100\right)$ \\
\hline Equation SR-8 & $\mathrm{P}_{\text {intake }}\left(\Phi_{\mathrm{fi}}\right)(\mathrm{kg})=\Sigma\left(\mathrm{DMI}_{\mathrm{d}} \times \Phi_{\mathrm{fi}} \times \% \mathrm{P}_{\text {totalt }} / 100\right)$ \\
\hline \multirow[t]{3}{*}{ Equation SR-10 } & $\operatorname{VS}\left(\Phi_{\mathrm{fi}}\right)(\mathrm{kg} /$ day $)=\mathrm{DMI} \times \Phi_{\mathrm{fi}} \times(1.04-\mathrm{DMD}) \times 0.92$ \\
\hline & Calculated impacts \\
\hline & Total \\
\hline Equation SR-11 & $\mathrm{N}_{\text {excreted }}\left(\Phi_{\mathrm{fi}}\right)(\mathrm{kg})=\mathrm{N}_{\text {intake }}\left(\Phi_{\mathrm{fi}}\right)-\mathrm{N}_{\text {product }}$ \\
\hline Equation SR-12 & $\mathrm{P}_{\text {excreted }}\left(\Phi_{\mathrm{fi}}\right)(\mathrm{kg})=\mathrm{P}_{\text {intake }}\left(\Phi_{\mathrm{fi}}\right)-\mathrm{P}_{\text {product }}$ \\
\hline Equation SR-14 & $\mathrm{CH}_{4 \text { manure }}\left(\Phi_{\mathrm{fi}}\right)(\mathrm{kg})=\Sigma\left(\mathrm{VS}_{\mathrm{d}}\left(\Phi_{\mathrm{fi}}\right) \times \mathrm{Bo} \times \mathrm{MCF}_{\mathrm{d}} \times 0.67\right)$ \\
\hline Equation SR-15 & $\mathrm{N}_{2} \mathrm{O}_{\text {manure }}\left(\Phi_{\mathrm{fi}}\right)($ refer to FAO, 2016c, Figure 11) \\
\hline
\end{tabular}




\begin{tabular}{lc}
\hline & Intensity \\
\hline Equation SR-16 & $\mathrm{N}_{\text {excreted }}$ Intensity $\left(\Phi_{\mathrm{fi}}\right)(\mathrm{kg} / \mathrm{kg} \mathrm{ECM})=\mathrm{N}_{\text {excreted }}\left(\Phi_{\mathrm{f}}\right) / \mathrm{ECM}$ \\
\hline Equation SR-17 & $\mathrm{P}_{\text {excreted }}$ Intensity $\left(\Phi_{\mathrm{fi}}\right)(\mathrm{kg} / \mathrm{kg} \mathrm{ECM})=\mathrm{P}_{\text {excreted }}\left(\Phi_{\mathrm{fi}}\right) / \mathrm{ECM}$ \\
\hline Equation SR-18 & $\mathrm{CH}_{4 \text { manure }}$ Intensity $\left(\Phi_{\mathrm{fi}}\right)(\mathrm{kg} / \mathrm{kg} \mathrm{ECM})=\mathrm{CH}_{4 \text { manure }}\left(\Phi_{\mathrm{fi}}\right) / \mathrm{ECM}$ \\
\hline Equation SR-19 & $\mathrm{N}_{2} \mathrm{O}_{\text {manure }}\left(\Phi_{\mathrm{fi}}\right)(\mathrm{kg} / \mathrm{kg}$ milk $)=\mathrm{N}_{2} \mathrm{O}_{\text {manure }}\left(\Phi_{\mathrm{fi}}\right) / \mathrm{ECM}$ \\
\hline
\end{tabular}

Note: $\Phi_{\mathrm{fi}}=$ change in feed intake; subscript $\mathrm{t}$ is a reference to the type of feed used and subscript $\mathrm{d}$ is a reference to the day (e.g. $\mathrm{ME}_{\mathrm{t}}$ is the metabolizable energy of the type of feed such as a production concentrate and $\mathrm{DMI}_{\mathrm{d}}$ is the dry matter intake of that type of feed on a given day).

In the case of a modification of the milk production, the ECM is also modified as follows:

$\operatorname{ECM}\left(\Phi_{\mathrm{mp}}\right)=\operatorname{Milk} \times \Phi_{\mathrm{mp}} \times(0.1226 \times \%$ fat $+0.0776 \times \%$ true protein +0.2534$)$

Hence the emission intensity is modified.

Table 18: Adaptation of equations for dairy ewes and goats (change in milk production)

\begin{tabular}{|c|c|}
\hline & Basis for calculation \\
\hline Equation SR-7 & $\mathrm{N}_{\text {product }}\left(\Phi_{\mathrm{mp}}\right)(\mathrm{kg})=\Sigma\left(\mathrm{Milk}_{\mathrm{d}} \times \Phi_{\mathrm{mp}} \times(\%\right.$ Protein in milk $\left.\mathrm{d} / 100) / 6.38\right)$ \\
\hline \multirow[t]{3}{*}{ Equation SR-9 } & $\mathrm{P}_{\text {product }}\left(\Phi_{\mathrm{mp}}\right)(\mathrm{kg})=\Sigma\left(\mathrm{Milk}_{\mathrm{d}} \times \Phi_{\mathrm{mp}} \times \% \mathrm{P}\right.$ in milk $\left.\mathrm{d} / 100\right)$ \\
\hline & Calculated impacts \\
\hline & Total \\
\hline Equation SR-11 & $\mathrm{N}_{\text {excreted }}\left(\Phi_{\mathrm{mp}}\right)(\mathrm{kg})=\mathrm{N}_{\text {intake }}\left(\Phi_{\mathrm{mp}}\right)-\mathrm{N}_{\text {product }}$ \\
\hline Equation SR-12 & $\mathrm{P}_{\text {excreted }}\left(\Phi_{\mathrm{mp}}\right)(\mathrm{kg})=\mathrm{P}_{\text {intake }}\left(\Phi_{\mathrm{mp}}\right)-\mathrm{P}_{\text {product }}$ \\
\hline \multirow[t]{2}{*}{ Equation SR-15 } & $\mathrm{N}_{2} \mathrm{O}_{\text {manure }}\left(\Phi_{\mathrm{mp}}\right)($ refer to FAO, 2016c, Figure 11) \\
\hline & Intensity \\
\hline Equation SR-16 & $\mathrm{N}_{\text {excreted }}$ Intensity $\left(\Phi_{\mathrm{mp}}\right)(\mathrm{kg} / \mathrm{kg} \mathrm{ECM})=\mathrm{N}_{\text {excreted }}\left(\Phi_{\mathrm{mp}}\right) / \mathrm{ECM}\left(\Phi_{\mathrm{mp}}\right)$ \\
\hline Equation SR-17 & $\mathrm{P}_{\text {excreted }}$ Intensity $\left(\Phi_{\mathrm{mp}}\right)(\mathrm{kg} / \mathrm{kg} \mathrm{ECM})=\mathrm{P}_{\text {excreted }}\left(\Phi_{\mathrm{mp}}\right) / \mathrm{ECM}\left(\Phi_{\mathrm{mp}}\right)$ \\
\hline Equation SR-18 & $\mathrm{CH}_{\text {4enteric }}$ Intensity $\left(\Phi_{\mathrm{mp}}\right)(\mathrm{kg} / \mathrm{kg} \mathrm{ECM})=\mathrm{CH}_{4 \text { enteric }} / \mathrm{ECM}\left(\Phi_{\mathrm{mp}}\right)$ \\
\hline Equation SR-19 & $\mathrm{CH}_{4 \text { manure }}$ Intensity $\left(\Phi_{\mathrm{mp}}\right)(\mathrm{kg} / \mathrm{kg} \mathrm{ECM})=\mathrm{CH}_{4 \text { manure }} / \mathrm{ECM}\left(\Phi_{\mathrm{mp}}\right)$ \\
\hline Equation SR-20 & $\mathrm{N}_{2} \mathrm{O}_{\text {manure }}$ Intensity $\left(\Phi_{\mathrm{mp}}\right)(\mathrm{kg} / \mathrm{kg} \mathrm{ECM})=\mathrm{N}_{2} \mathrm{O}_{\text {manure }}\left(\Phi_{\mathrm{mp}}\right) / \mathrm{ECM}\left(\Phi_{\mathrm{mp}}\right)$ \\
\hline
\end{tabular}

Note: $\Phi_{\mathrm{mp}}=$ change in milk production; subscript $\mathrm{d}$ is a reference to the day (e.g. Milk $\mathrm{d}_{\mathrm{d}}$ is the milk production on a given day).

When the feed additive or the combination of feed additives modifies the milk composition, the factor $\Phi_{\mathrm{mc}}$ is used in the equations (Table 19). It should be noted that the factor might be different for the changes observed (e.g. $\Phi_{\mathrm{mc}}$ can be 1.05 for change in protein concentration and 0.98 for change in fat concentration). The modification of milk composition has an impact on the ECM, as described below:

$\operatorname{ECM}\left(\Phi_{\mathrm{mc}}\right)=\operatorname{Milk} \times\left(0.1226 \times \%\right.$ fat $\times \Phi_{\mathrm{mc}}+0.0776 \times \%$ true protein $\left.\times \Phi_{\mathrm{mc}}+0.2534\right)$

Hence the emission intensity is modified. 
Table 19: Adaptation of equations for dairy ewes and goats (change in milk composition)

\begin{tabular}{|c|c|}
\hline & Basis for calculation \\
\hline Equation SR-7 & $\mathrm{N}_{\text {product }}\left(\Phi_{\mathrm{mc}}\right)(\mathrm{kg})=\Sigma\left(\mathrm{Milk}_{\mathrm{d}} \times\left(\%\right.\right.$ Protein in milk $\left.\left.\mathrm{d} \times \Phi_{\mathrm{mc}} / 100\right) / 6.38\right)$ \\
\hline \multirow[t]{3}{*}{ Equation SR-9 } & $\mathrm{P}_{\text {product }}\left(\Phi_{\mathrm{mc}}\right)(\mathrm{kg})=\Sigma\left(\mathrm{Milk}_{\mathrm{d}} \times \Phi_{\mathrm{mp}} \times \% \mathrm{P}\right.$ in milk $\left.\mathrm{d} \times \Phi_{\mathrm{mc}}\right) / 100$ \\
\hline & Calculated impacts \\
\hline & Total \\
\hline Equation SR-11 & $\mathrm{N}_{\text {excreted }}\left(\Phi_{\mathrm{mc}}\right)(\mathrm{kg})=\mathrm{N}_{\text {intake }}-\mathrm{N}_{\text {product }}\left(\Phi_{\mathrm{mc}}\right)$ \\
\hline Equation SR-12 & $\mathrm{P}_{\text {excreted }}\left(\Phi_{\mathrm{mc}}\right)(\mathrm{kg})=\mathrm{P}_{\text {intake }}-\mathrm{P}_{\text {product }}\left(\Phi_{\mathrm{mc}}\right)$ \\
\hline \multirow[t]{2}{*}{ Equation SR-15 } & $\mathrm{N}_{2} \mathrm{O}_{\text {manure }}\left(\Phi_{\mathrm{mc}}\right)($ refer to FAO, 2016c, Figure 11) \\
\hline & Intensity \\
\hline Equation SR-16 & $\mathrm{N}_{\text {excreted }}$ Intensity $\left(\Phi_{\mathrm{mc}}\right)(\mathrm{kg} / \mathrm{kg} \mathrm{ECM})=\mathrm{N}_{\text {excreted }}\left(\Phi_{\mathrm{mc}}\right) / \mathrm{ECM}\left(\Phi_{\mathrm{mc}}\right)$ \\
\hline Equation SR-17 & $\mathrm{P}_{\text {excreted }}$ Intensity $\left(\Phi_{\mathrm{mc}}\right)(\mathrm{kg} / \mathrm{kg} \mathrm{ECM})=\mathrm{P}_{\text {excreted }}\left(\Phi_{\mathrm{mc}}\right) / \mathrm{ECM}\left(\Phi_{\mathrm{mc}}\right)$ \\
\hline Equation SR-18 & $\mathrm{CH}_{\text {4enteric }}$ Intensity $\left(\Phi_{\mathrm{mc}}\right)(\mathrm{kg} / \mathrm{kg} \mathrm{ECM})=\mathrm{CH}_{\text {4enteric }} / \mathrm{ECM}\left(\Phi_{\mathrm{mc}}\right)$ \\
\hline Equation SR-19 & $\mathrm{CH}_{4 \text { manure }}$ Intensity $\left(\Phi_{\mathrm{mc}}\right)(\mathrm{kg} / \mathrm{kg} \mathrm{ECM})=\mathrm{CH}_{4 \text { manure }} / \mathrm{ECM}\left(\Phi_{\mathrm{mc}}\right)$ \\
\hline Equation SR-20 & $\mathrm{N}_{2} \mathrm{O}_{\text {manure }}$ Intensity $\left(\Phi_{\mathrm{mc}}\right)(\mathrm{kg} / \mathrm{kg} \mathrm{ECM})=\mathrm{N}_{2} \mathrm{O}_{\text {manure }}\left(\Phi_{\mathrm{mc}}\right) / \mathrm{ECM}\left(\Phi_{\mathrm{mc}}\right)$ \\
\hline
\end{tabular}

Note: $\Phi_{\mathrm{mc}}=$ change in milk composition; subscript $\mathrm{d}$ is a reference to the day (e.g. Milk $\mathrm{k}_{\mathrm{d}}$ is the milk production on a given day).

When the feed additive or the combination has a direct effect on methane $\left(\mathrm{CH}_{4}\right)$ or nitrous oxide $\left(\mathrm{N}_{2} \mathrm{O}\right)$ emissions, the factor $\Phi_{\mathrm{ef}}$ is used for the modification of the emission factor in the relevant equations. Although the factor is named in the same way in the equations $\left(\Phi_{\mathrm{ef}}\right)$, it will differ for the relevant emissions.

Table 20: Adaptation of equations for dairy ewes and goats (change in emission factor)

\begin{tabular}{|c|c|}
\hline & Calculated impacts \\
\hline & Total \\
\hline Equation SR-13 & $\mathrm{CH}_{4 \text { enteric }}\left(\Phi_{\mathrm{ef}}\right)(\mathrm{kg})=\Sigma\left(\mathrm{GE}_{\mathrm{d}} \times \mathrm{EF}_{\mathrm{d}} \times \Phi_{\mathrm{ef}} / 55.65\right)$ \\
\hline Equation SR-14 & $\mathrm{CH}_{4 \text { manure }}\left(\Phi_{\mathrm{ef}}\right)(\mathrm{kg})=\Sigma\left(\mathrm{VS}_{\mathrm{d}} \times \mathrm{Bo} \times \mathrm{MCF}_{\mathrm{d}} \times \Phi_{\mathrm{ef}} \times 0.67\right)$ \\
\hline \multirow[t]{2}{*}{ Equation SR-15 } & $\mathrm{N}_{2} \mathrm{O}_{\text {manure }}\left(\Phi_{\text {ef }}\right)($ refer to FAO, 2016c, Figure 11) \\
\hline & Intensity \\
\hline Equation SR-18 & $\mathrm{CH}_{4 \text { enteric }}$ Intensity $\left(\Phi_{\mathrm{ef}}\right)(\mathrm{kg} / \mathrm{kg} \mathrm{ECM})=\mathrm{CH}_{4 \text { enteric }}\left(\Phi_{\mathrm{ef}}\right) / \mathrm{ECM}$ \\
\hline Equation SR-19 & $\mathrm{CH}_{4 \text { manure }}$ Intensity $\left(\Phi_{\mathrm{ef}}\right)(\mathrm{kg} / \mathrm{kg} \mathrm{ECM})=\mathrm{CH}_{4 \text { manure }}\left(\Phi_{\mathrm{ef}}\right) / \mathrm{ECM}$ \\
\hline Equation SR-20 & $\mathrm{N}_{2} \mathrm{O}_{\text {manure }}$ Intensity $\left(\Phi_{\mathrm{ef}}\right)(\mathrm{kg} / \mathrm{kg} \mathrm{ECM})=\mathrm{N}_{2} \mathrm{O}_{\text {manure }}\left(\Phi_{\mathrm{ef}}\right) / \mathrm{ECM}$ \\
\hline
\end{tabular}

\section{iv. Small ruminants (lambs and kids)}

\section{Baseline scenario}

Table 21 lists the equations relevant for the evaluation of the environmental impact of lambs and kids for the baseline scenario. The calculated impacts will be the comparison point for the feed additive scenario. Definitions of parameters and variables used in the equations are given in Table 2. 
Table 21: Equations used for evaluating the baseline emissions for lambs and kids

\begin{tabular}{|c|c|}
\hline & Basis for calculation \\
\hline Equation SR-1 & $\begin{array}{c}\mathrm{ME}_{\text {intakeother }}(\mathrm{MJ})=\Sigma\left(\text { Total } \mathrm{ME}_{\mathrm{d}} \text { requirements }-\left(\mathrm{DMI}_{\mathrm{d}} \times \mathrm{ME}_{\mathrm{t}} / \mathrm{kg} \mathrm{DM}\right)_{\mathrm{feed} 1}-\right. \\
\left.\left(\mathrm{DMI}_{\mathrm{d}} \times \mathrm{ME}_{\mathrm{t}} / \mathrm{kg} \mathrm{DM}\right)_{\text {feed } 2}\right)\end{array}$ \\
\hline Equation SR-2 & $\mathrm{DMI}_{\text {other }}(\mathrm{kg})=\mathrm{ME}_{\text {intakeother }} /(\mathrm{ME} / \mathrm{kg} \mathrm{DM})$ \\
\hline Equation SR-3 & $\operatorname{REG}(\%)=1.164-\left(5.160 \times 10^{3} \times \% \mathrm{DE}\right)+\left(1.038 \times 10^{-5} \times \% \mathrm{DE}^{2}\right)-(37.4 / \% \mathrm{DE})$ \\
\hline Equation SR-4 & $\operatorname{REM}(\%)=1.123-\left(4.092 \times 10^{3} \times \% \mathrm{DE}\right)+\left(1.126 \times 10^{-5} \times \% \mathrm{DE}^{2}\right)-(25.4 / \% \mathrm{DE})$ \\
\hline Equation SR-5 & $\begin{aligned} \mathrm{GE}(\mathrm{MJ} / \text { day })= & \left(\left(\mathrm{NE}_{\text {maintenance }}+\mathrm{NE}_{\text {activity }}+\mathrm{NE}_{\text {lactation }}+\mathrm{NE}_{\text {pregnancy }}\right) / \mathrm{REM}+\right. \\
& \left.\left(\mathrm{NE}_{\text {growth }}+\mathrm{NE}_{\mathrm{wool}}\right) / \mathrm{REG}\right) /(\% \mathrm{DE} / 100)\end{aligned}$ \\
\hline Equation SR-6a & $\% \mathrm{~N}$ in feed $(\%)=\% \mathrm{CP} / 6.25$ \\
\hline Equation SR-6b & $\mathrm{N}_{\text {intake }}(\mathrm{kg})=\Sigma\left(\mathrm{DMI}_{\mathrm{d}} \times \% \mathrm{~N}\right.$ in feed $\left./ 100\right)$ \\
\hline Equation SR-7 & $\mathrm{N}_{\text {product }}(\mathrm{kg})=(\mathrm{TWG} \times \%$ Protein in tissues $/ 100) / 6.25$ \\
\hline Equation SR-8 & $\mathrm{P}_{\text {intake }}(\mathrm{kg})=\Sigma\left(\mathrm{DMI}_{\mathrm{d}} \times \% \mathrm{P}_{\text {totalt }} / 100\right)$ \\
\hline Equation SR-9 & $\mathrm{P}_{\text {product }}(\mathrm{kg})=\mathrm{TWG}(\mathrm{kg}$ live weight $) \times \% \mathrm{P}$ in tissues and bones $/ 100$ \\
\hline \multirow[t]{3}{*}{ Equation SR-10 } & $\mathrm{VS}(\mathrm{kg} /$ day $)=\mathrm{DMI} \times(1.04-\mathrm{DMD}) \times 0.92$ \\
\hline & Calculated impacts \\
\hline & Total \\
\hline Equation SR-11 & $\mathrm{N}_{\text {excreted }}(\mathrm{kg})=\mathrm{N}_{\text {intake }}-\mathrm{N}_{\text {product }}$ \\
\hline Equation SR-12 & $\mathrm{P}_{\text {excreted }}(\mathrm{kg})=\mathrm{P}_{\text {intake }}-\mathrm{P}_{\text {product }}$ \\
\hline Equation SR-13 & $\mathrm{CH}_{4 \text { enteric }}(\mathrm{kg})=\Sigma\left(\mathrm{GE}_{\mathrm{d}} \times \mathrm{EF}_{\mathrm{d}} / 55.65\right)$ \\
\hline Equation SR-14 & $\mathrm{CH}_{4 \text { manure }}(\mathrm{kg})=\Sigma\left(\mathrm{VS}_{\mathrm{d}} \times \mathrm{Bo} \times \mathrm{MCF}_{\mathrm{d}} \times 0.67\right)$ \\
\hline \multirow[t]{2}{*}{ Equation SR-15 } & $\mathrm{N}_{2} \mathrm{O}_{\text {manure }}($ refer to FAO, 2016c, Figure 11) \\
\hline & Intensity \\
\hline Equation SR-16 & $\mathrm{N}_{\text {excreted }}$ Intensity $(\mathrm{kg} / \mathrm{kg}$ live weight $)=\mathrm{N}_{\text {excreted }} / \mathrm{TWG}$ \\
\hline Equation SR-17 & $\mathrm{P}_{\text {excreted }}$ Intensity $(\mathrm{kg} / \mathrm{kg}$ live weight $)=\mathrm{P}_{\text {excreted }} / \mathrm{TWG}$ \\
\hline Equation SR-18 & $\mathrm{CH}_{4 \text { enteric }}$ Intensity $(\mathrm{kg} / \mathrm{kg}$ live weight $)=\mathrm{CH}_{4 \text { enteric }} / \mathrm{TWG}$ \\
\hline Equation SR-19 & $\mathrm{CH}_{4 \text { manure }}$ Intensity $(\mathrm{kg} / \mathrm{kg}$ live weight $)=\mathrm{CH}_{4 \text { manure }} / \mathrm{TWG}$ \\
\hline Equation SR-20 & $\mathrm{N}_{2} \mathrm{O}_{\text {manure }}$ Intensity $(\mathrm{kg} / \mathrm{kg}$ live weight $)=\mathrm{N}_{2} \mathrm{O}_{\text {manure }} / \mathrm{TWG}$ \\
\hline
\end{tabular}

Note: Subscript $\mathrm{t}$ is a reference to the type of feed used and subscript $\mathrm{d}$ is a reference to the day (e.g. $\mathrm{ME}_{\mathrm{t}}$ is the metabolizable energy of the type of feed such as a production concentrate and $\mathrm{DMI}_{\mathrm{d}}$ is the dry matter intake of that type of feed on a given day).

\section{Feed additive scenarios}

Tables 22-26 provide the changes in the equations linked to the effect of the feed additives or a combination of feed additives on the parameters. Each table provides information on the following potential effects of the feed additives or the combinations of feed additives, as described in subsection 6.10.3 (i-iii):

- modification of feed composition (Table 22)

- feed efficiency (Tables 23, 24, 25)

- emission factors (Table 26)

When the change in the equations used as a basis for the calculation (upper part of the tables) modifies the calculated impact, the corresponding equations are indicated as well (lower part of the tables). As an example, when the concentration of nitrogen is changed in the diet (use of the factor $\Phi_{\text {nc }}$ ), the result of both the $\mathrm{N}_{\text {intake }}$ and the $\mathrm{N}_{\text {excreted }}$ is changed. Hence these equations are also indicated. It should be noted that the factor might be different for the changes observed (e.g. $\Phi_{\mathrm{nc}}$ can be 1.05 for change in protein concentration and 0.98 for change in phosphorus concentration). 
Table 22: Adaptation of equations for lambs and kids (change in feed composition)

\begin{tabular}{lc} 
Equation SR-6a & Basis for calculation \\
\hline Equation SR-6b & $\mathrm{N}_{\text {intake }}\left(\Phi_{\mathrm{nc}}\right)(\mathrm{kg})=\Sigma\left(\mathrm{DMI}_{\mathrm{d}} \times \% \mathrm{~N}\right.$ in feed $\left.\mathrm{t}_{\mathrm{t}}\left(\Phi_{\mathrm{nc}}\right) / 100\right)$ \\
\hline Equation SR-8 & $\mathrm{P}_{\text {intake }}\left(\Phi_{\mathrm{nc}}\right)(\mathrm{kg})=\Sigma\left(\mathrm{DMI}_{\mathrm{d}} \times \% \mathrm{P}_{\text {totalt }} \times \Phi_{\mathrm{nc}} / 100\right)$ \\
& Calculated impacts \\
\hline Equation SR-11 & Total \\
\hline Equation SR-12 & $\mathrm{N}_{\text {excreted }}\left(\Phi_{\mathrm{nc}}\right)(\mathrm{kg})=\mathrm{N}_{\text {intake }}\left(\Phi_{\mathrm{nc}}\right)-\mathrm{N}_{\text {product }}$ \\
\hline & $\mathrm{P}_{\text {excreted }}\left(\Phi_{\mathrm{nc}}\right)(\mathrm{kg})=\mathrm{P}_{\text {intake }}\left(\Phi_{\mathrm{nc}}\right)-\mathrm{P}_{\text {product }}$ \\
\hline Equation SR-16 & Intensity \\
\hline Equation SR-17 & $\mathrm{N}_{\text {excreted }}$ Intensity $\left(\Phi_{\mathrm{nc}}\right)(\mathrm{kg} / \mathrm{kg}$ live weight $)=\mathrm{N}_{\text {excreted }}\left(\Phi_{\mathrm{nc}}\right) / \mathrm{TWG}$ \\
\hline
\end{tabular}

Note: $\Phi_{\mathrm{nc}}=$ change in feed composition (protein and phosphorus content); subscript $\mathrm{t}$ is a reference to the type of feed used and subscript $d$ is a reference to the day (e.g. $\mathrm{DMI}_{\mathrm{d}}$ is the dry matter intake of that type of feed on a given day).

When a feed additive or combination of feed additives modifies the feed efficiency of lambs and kids, it could be through a modification of one or more of the following:

- feed intake $\left(\Phi_{\mathrm{fi}}\right)($ Table 23$)$

- weight gain $\left(\Phi_{\mathrm{wg}}\right)($ Table 24$)$

- modification of the weight gain composition $\left(\Phi_{\mathrm{wgc}}\right)$ (Table 25$)$

In the case that the feed additive or the combination of feed additives has an impact on more than one of the above-mentioned parameters, it is advised to combine the different impact accordingly. For example, if the feed additive or combination of feed additives modifies the feed intake $\left(\Phi_{\mathrm{fi}}\right)$ and the weight gain $\left(\Phi_{\mathrm{wg}}\right)$, the nitrogen balance will be recalculated as follows:

- $\mathrm{N}_{\text {intake }}\left(\Phi_{\mathrm{fi}}\right)(\mathrm{kg})=\mathrm{DMI} \times \Phi_{\mathrm{fi}} \times \% \mathrm{~N}$ in feed/100 (Equation LR-4b adapted)

- $\mathrm{N}_{\text {product }}\left(\Phi_{\mathrm{wg}}\right)(\mathrm{kg})=\mathrm{TWG} \times \Phi_{\mathrm{wg}} \times \%$ Protein in tissues/100/6.25 (Equation LR-7 adapted)

This will lead to a modification of the nitrogen excretion.

Table 23: Adaptation of equations for lambs and kids (change in feed intake)

\begin{tabular}{|c|c|}
\hline & Basis for calculation \\
\hline Equation SR-1 & $\begin{aligned} \mathrm{ME}_{\text {intakeother }}\left(\Phi_{\mathrm{fi}}\right)(\mathrm{MJ})=\Sigma\left(\text { Total }_{\mathrm{ME}} \text { requirements }-\left(\mathrm{DMI}_{\mathrm{d}} \times \Phi_{\mathrm{fi}} \times \mathrm{ME}_{\mathrm{t}} / \mathrm{kg} \mathrm{DM}\right)_{\mathrm{feed} 1}-\right. & \left.\left(\mathrm{DMI}_{\mathrm{d}} \times \Phi_{\mathrm{fi}} \times \mathrm{ME}_{\mathrm{t}} / \mathrm{kg} \mathrm{DM}\right)_{\mathrm{feed} 2}\right)\end{aligned}$ \\
\hline Equation SR-2 & $\mathrm{DMI}_{\text {other }}\left(\Phi_{\mathrm{fi}}\right)(\mathrm{kg})=\mathrm{ME}_{\text {intakeother }}\left(\Phi_{\mathrm{fi}}\right) /(\mathrm{ME} / \mathrm{kg} \mathrm{DM})$ \\
\hline Equation SR-6a & $\% \mathrm{~N}$ in feed $(\%)=\% \mathrm{CP} / 6.25$ \\
\hline Equation SR-6b & $\mathrm{N}_{\text {intake }}\left(\Phi_{\mathrm{f}}\right)(\mathrm{kg})=\Sigma\left(\mathrm{DMI}_{\mathrm{d}} \times \Phi_{\mathrm{fi}} \times \% \mathrm{~N}\right.$ in feed $\left.\mathrm{f}_{\mathrm{t}} / 100\right)$ \\
\hline Equation SR-8 & $\mathrm{P}_{\text {intake }}\left(\Phi_{\mathrm{fi}}\right)=\Sigma\left(\mathrm{DMI}_{\mathrm{d}} \times \Phi_{\mathrm{fi}} \times \% \mathrm{P}_{\text {totalt }} / 100\right)$ \\
\hline \multirow[t]{3}{*}{ Equation SR-10 } & $\operatorname{VS}\left(\Phi_{\mathrm{fi}}\right)(\mathrm{kg} /$ day $)=\mathrm{DMI} \times \Phi_{\mathrm{fi}} \times(1.04-\mathrm{DMD}) \times 0.92$ \\
\hline & Calculated impacts \\
\hline & Total \\
\hline Equation SR-11 & $\mathrm{N}_{\text {excreted }}\left(\Phi_{\mathrm{fi}}\right)(\mathrm{kg})=\mathrm{N}_{\text {intake }}\left(\Phi_{\mathrm{fi}}\right)-\mathrm{N}_{\text {product }}$ \\
\hline Equation SR-12 & $\mathrm{P}_{\text {excreted }}\left(\Phi_{\mathrm{fi}}\right)(\mathrm{kg})=\mathrm{P}_{\text {intake }}\left(\Phi_{\mathrm{fi}}\right)-\mathrm{P}_{\text {product }}$ \\
\hline Equation SR-14 & $\mathrm{CH}_{4 \text { manure }}\left(\Phi_{\mathrm{fi}}\right)(\mathrm{kg})=\Sigma\left(\mathrm{VS}_{\mathrm{d}}\left(\Phi_{\mathrm{fi}}\right) \times \mathrm{Bo} \times \mathrm{MCF}_{\mathrm{d}} \times 0.67\right)$ \\
\hline Equation SR-15 & $\mathrm{N}_{2} \mathrm{O}_{\text {manure }}\left(\Phi_{\mathrm{fi}}\right)($ refer to FAO, 2016c, Figure 11) \\
\hline
\end{tabular}




\begin{tabular}{lc}
\hline & Intensity \\
\hline Equation SR-16 & $\mathrm{N}_{\text {excreted }}$ Intensity $\left(\Phi_{\mathrm{fi}}\right)(\mathrm{kg} / \mathrm{kg}$ live weight $)=\mathrm{N}_{\text {excreted }}\left(\Phi_{\mathrm{fi}}\right) / \mathrm{TWG}$ \\
\hline Equation SR-17 & $\mathrm{P}_{\text {excreted }}$ Intensity $\left(\Phi_{\mathrm{fi}}\right)(\mathrm{kg} / \mathrm{kg}$ live weight $)=\mathrm{P}_{\text {excreted }}\left(\Phi_{\mathrm{fi}}\right) / \mathrm{TWG}$ \\
\hline Equation SR-19 & $\mathrm{CH}_{4 \text { manure }}$ Intensity $\left(\Phi_{\mathrm{f}}\right)(\mathrm{kg} / \mathrm{kg}$ live weight $)=\mathrm{CH}_{4 \text { manure }}\left(\Phi_{\mathrm{fi}}\right) / \mathrm{TWG}$ \\
\hline Equation SR-20 & $\mathrm{N}_{2} \mathrm{O}_{\text {manure }}$ Intensity $\left(\Phi_{\mathrm{fi}}\right)(\mathrm{kg} / \mathrm{kg}$ live weight $)=\mathrm{N}_{2} \mathrm{O}_{\text {manure }}\left(\Phi_{\mathrm{fi}}\right) / \mathrm{TWG}$ \\
\hline
\end{tabular}

Note: $\Phi_{\mathrm{fi}}=$ change in feed intake; subscript $\mathrm{t}$ is a reference to the type of feed used and subscript $\mathrm{d}$ is a reference to the day (e.g. $\mathrm{ME}_{\mathrm{t}}$ is the metabolizable energy of the type of feed such as a production concentrate and $\mathrm{DMI}_{\mathrm{d}}$ is the dry matter intake of that type of feed on a given day).

In the case of a modification of the animal performance, the total weight gain is modified as follows:

$$
\mathrm{TWG}\left(\Phi_{\mathrm{gp}}\right)=\mathrm{TWG} \times \Phi_{\mathrm{gp}}
$$

Hence the emission intensity is modified.

Table 24: Adaptation of equations for lambs and kids (change in growth performance)

\begin{tabular}{lc} 
Equation SR-7 & $\mathrm{N}_{\text {product }}\left(\Phi_{\mathrm{gp}}\right)(\mathrm{kg})=\left(\mathrm{TWG} \times \Phi_{\mathrm{gp}} \times \%\right.$ Protein in tissues $\left./ 100\right) / 6.25$ \\
\hline Equation SR-9 & $\mathrm{P}_{\text {product }}\left(\Phi_{\mathrm{gp}}\right)(\mathrm{kg})=\mathrm{TWG} \times \Phi_{\mathrm{gp}} \times \%$ P in tissues and bones $/ 100$ \\
& Calculated impacts \\
\hline Equation SR-11 & Total \\
\hline Equation SR-12 & $\mathrm{N}_{\text {excreted }}\left(\Phi_{\mathrm{gp}}\right)(\mathrm{kg})=\mathrm{N}_{\text {intake }}-\mathrm{N}_{\text {product }}\left(\Phi_{\mathrm{gp}}\right)$ \\
\hline Equation SR-15 & $\mathrm{P}_{\text {excreted }}\left(\Phi_{\mathrm{gp}}\right)(\mathrm{kg})=\mathrm{P}_{\text {intake }}-\mathrm{P}_{\text {product }}\left(\Phi_{\mathrm{gp}}\right)$ \\
\hline & $\mathrm{N}_{2} \mathrm{O}_{\text {manure }}\left(\Phi_{\mathrm{gp}}\right)(\mathrm{refer}$ to FAO, 2016c, Figure 11$)$ \\
\hline Equation SR-19 & Intensity \\
\hline Equation SR-17 & $\mathrm{N}_{\text {excreted }}$ Intensity $\left(\Phi_{\mathrm{gp}}\right)(\mathrm{kg} / \mathrm{kg}$ live weight $)=\mathrm{N}_{\text {excreted }}\left(\Phi_{\mathrm{gp}}\right) / \mathrm{TWG}\left(\Phi_{\mathrm{gp}}\right)$ \\
\hline Equation SR-18 & $\mathrm{P}_{\text {excreted }}$ Intensity $\left(\Phi_{\mathrm{gp}}\right)(\mathrm{kg} / \mathrm{kg}$ live weight $)=\mathrm{P}_{\text {excreted }}\left(\Phi_{\mathrm{gp}}\right) / \mathrm{TWG}\left(\Phi_{\mathrm{gp}}\right)$ \\
\hline Equation SR-19 & $\mathrm{CH}_{4 \text { enteric }}$ Intensity $\left(\Phi_{\mathrm{gp}}\right)(\mathrm{kg} / \mathrm{kg}$ live weight $)=\mathrm{CH}_{4 \text { enteric }} / \mathrm{TWG}\left(\Phi_{\mathrm{gp}}\right)$ \\
\hline Equation SR-20 & $\mathrm{CH}_{4 \text { manure }}$ Intensity $\left(\Phi_{\mathrm{gp}}\right)(\mathrm{kg} / \mathrm{kg}$ live weight $)=\mathrm{CH}_{4 \text { manure }} / \mathrm{TWG}\left(\Phi_{\mathrm{gp}}\right)$ \\
\hline
\end{tabular}

Note: $\Phi_{\mathrm{gp}}=$ change in growth performance.

When the feed additive or the combination of feed additives modifies the body weight gain composition, the factor $\Phi_{\text {bwc }}$ is used in the equations (Table 24). It should be noted that the factor might be different for the changes observed (e.g. $\Phi_{\text {bwc }}$ can be 1.05 for change in protein concentration and 0.98 for change in phosphorus concentration). 
Table 25: Adaptation of equations for lambs and kids (change in body weight gain composition)

\begin{tabular}{lc} 
Equation SR-7 & $\begin{array}{c}\text { Basis for calculation } \\
\mathrm{N}_{\text {product }}\left(\Phi_{\mathrm{bwc}}\right)(\mathrm{kg})=\left(\mathrm{TWG} \times \% \text { Protein in tissues } \times \Phi_{\mathrm{bwc}} / 100\right) / 6.25\end{array}$ \\
\hline Equation SR-9 & $\mathrm{P}_{\text {product }}\left(\Phi_{\mathrm{bwc}}\right)(\mathrm{kg})=\mathrm{TWG} \times \%$ P in tissues and bones $\times \Phi_{\mathrm{bwc}} / 100$ \\
& Calculated impacts \\
\hline Equation SR-11 & Total \\
\hline Equation SR-12 & $\mathrm{N}_{\text {excreted }}\left(\Phi_{\mathrm{bwc}}\right)(\mathrm{kg})=\mathrm{N}_{\text {intake }}-\mathrm{N}_{\text {product }}\left(\Phi_{\mathrm{bwc}}\right)$ \\
\hline Equation SR-15 & $\mathrm{P}_{\text {excreted }}\left(\Phi_{\mathrm{bwc}}\right)(\mathrm{kg})=\mathrm{P}_{\text {intake }}-\mathrm{P}_{\text {product }}\left(\Phi_{\mathrm{bwc}}\right)$ \\
\hline & $\mathrm{N}_{2} \mathrm{O}_{\text {manure }}\left(\Phi_{\mathrm{bwc}}\right)(\mathrm{refer}$ to FAO, 2016c, Figure 11$)$ \\
\hline Equation SR-16 & Intensity \\
\hline Equation SR-17 & $\mathrm{N}_{\text {excreted }}$ Intensity $\left(\Phi_{\mathrm{bwc}}\right)(\mathrm{kg} / \mathrm{kg}$ live weight $)=\mathrm{N}_{\text {excreted }}\left(\Phi_{\mathrm{bwc}}\right) / \mathrm{TWG}$ \\
\hline Equation SR-20 & $\mathrm{P}_{\text {excreted }}$ Intensity $\left(\Phi_{\mathrm{bwc}}\right)(\mathrm{kg} / \mathrm{kg}$ live weight $)=\mathrm{P}_{\text {excreted }}\left(\Phi_{\mathrm{bwc}}\right) / \mathrm{TWG}$ \\
\hline
\end{tabular}

Note: $\Phi_{\text {bwc }}=$ change in body weight gain composition.

When the feed additive or the combination has a direct effect on methane $\left(\mathrm{CH}_{4}\right)$ or nitrous oxide $\left(\mathrm{N}_{2} \mathrm{O}\right)$ emissions, the factor $\Phi_{\text {ef }}$ is used for the modification of the emission factor in the relevant equations. Although the factor is named in the same way in the equations $\left(\Phi_{\mathrm{ef}}\right)$, it will differ for the relevant emissions.

Table 26: Adaptation of equations for lambs and kids (change in emission factor)

\begin{tabular}{lc} 
& \multicolumn{1}{c}{ Calculated impacts } \\
\hline Equation SR-13 & $\mathrm{CH}_{\text {4enteric }}\left(\Phi_{\mathrm{ef}}\right)(\mathrm{kg})=\Sigma\left(\mathrm{GE}_{\mathrm{d}} \times \mathrm{EF}_{\mathrm{d}} \times \Phi_{\mathrm{ef}} / 55.65\right)$ \\
\hline Equation SR-14 & $\mathrm{CH}_{4 \text { manure }}\left(\Phi_{\mathrm{ef}}\right)(\mathrm{kg})=\Sigma\left(\mathrm{VS}_{\mathrm{d}} \times \mathrm{Bo} \times \mathrm{MCF}_{\mathrm{d}} \times \Phi_{\mathrm{ef}} \times 0.67\right)$ \\
\hline Equation SR-15 & $\mathrm{N}_{2} \mathrm{O}_{\text {manure }}\left(\Phi_{\mathrm{ef}}\right)(\mathrm{refer}$ to FAO, 2016c, Figure 11) \\
\hline Equation SR-18 & Intensity \\
\hline Equation SR-19 & $\mathrm{CH}_{\text {4enteric }}$ Intensity $\left(\Phi_{\mathrm{ef}}\right)(\mathrm{kg} / \mathrm{kg}$ live weight $)=\mathrm{CH}_{\text {4enteric }}\left(\Phi_{\mathrm{ef}}\right) / \mathrm{TWG}$ \\
\hline Equation SR-20 & $\mathrm{CH}_{4 \text { manure }}$ Intensity $\left(\Phi_{\mathrm{ef}}\right)(\mathrm{kg} / \mathrm{kg}$ live weight $)=\mathrm{CH}_{4 \text { manure }}\left(\Phi_{\mathrm{ef}}\right) / \mathrm{TWG}$ \\
\hline
\end{tabular}

Note: $\Phi_{\text {ef }}=$ change in emission factor; subscript $\mathrm{d}$ is a reference to the day (e.g. $\mathrm{GE}_{\mathrm{d}}$ is the gross energy intake on a given day).

\section{v. Pigs}

\section{Baseline scenario}

Table 27 lists the equations relevant for the evaluation of the environmental impact of pigs for the baseline scenario. The equations originating from the LEAP pigs guidelines (FAO, 2018b) are noted "Equation PI-n" (e.g. Equation PI-9). For consistency with the other species and while the detailed equations are not available in the pigs guidelines, additional equations are included, noted "Equation FA-n" (e.g. Equation FA-1). The calculated impacts will be the comparison point for the feed additive scenario. Definitions of parameters and variables used in the equations are given in Table 2.

Pig production comprises different phases (lactating sows, gestating sows, piglets, growers and finishers). When calculating the impact, the sum of the impacts during the different phases should be calculated. 
Table 27: Equations used for evaluating the baseline emissions for pigs

\begin{tabular}{|c|c|}
\hline & Basis for calculation \\
\hline Equation FA-1 & $\mathrm{N}_{\text {intake }}(\mathrm{kg})=\Sigma\left(\mathrm{FI}_{\mathrm{Ph}} \times\left(\% \mathrm{CP}_{\mathrm{Ph}} / 100\right)\right) / 6.25$ \\
\hline Equation FA-2 & $\mathrm{N}_{\text {retention }}(\mathrm{kg})=\mathrm{TWG} \times(\%$ Protein in tissues $/ 100) / 6.25$ \\
\hline Equation FA-3 & $\mathrm{P}_{\text {intake }}(\mathrm{kg})=\Sigma\left(\mathrm{FI}_{\mathrm{Ph}} \times \% \mathrm{P}_{\text {totalPh }}\right) / 100$ \\
\hline Equation FA-4 & $\mathrm{P}_{\text {retention }}(\mathrm{kg})=\mathrm{TWG} \times \% \mathrm{P}$ in tissues and bones $/ 100$ \\
\hline Equation FA-5 & $\mathrm{Cu}_{\text {intake }}(\mathrm{kg})=\Sigma\left(\mathrm{FI}_{\mathrm{Ph}} \times \% \mathrm{Cu}_{\mathrm{Ph}}\right) / 100$ \\
\hline Equation FA-6 & $\mathrm{Cu}_{\text {retention }}(\mathrm{kg})=\mathrm{TWG} \times \% \mathrm{Cu}$ in tissues and bones $/ 100$ \\
\hline Equation FA-7 & $\mathrm{Zn}_{\text {intake }}(\mathrm{kg})=\Sigma\left(\mathrm{FI}_{\mathrm{Ph}} \times \% \mathrm{Zn}_{\mathrm{Ph}}\right) / 100$ \\
\hline Equation FA-8 & $\mathrm{Zn}_{\text {retention }}(\mathrm{kg})=\mathrm{TWG} \times \% \mathrm{Zn}$ in tissues and bones $/ 100$ \\
\hline Equation PI-9 & $\mathrm{VS}(\mathrm{kg})=\Sigma\left(\mathrm{FI}_{\mathrm{Ph}} \times\left(1-\mathrm{DMD}_{\mathrm{Ph}}\right) \times(1-\mathrm{A})+\mathrm{VS}_{\mathrm{WF}}\right)$ \\
\hline \multirow[t]{3}{*}{ Equation PI-10 } & $\mathrm{VS}_{\mathrm{WF}}(\mathrm{kg})=\Sigma\left(\mathrm{FI}_{\mathrm{Ph}} \times(1-\mathrm{A}) \times \mathrm{WF}_{\mathrm{Ph}}\right)$ \\
\hline & Calculated impacts \\
\hline & Total \\
\hline Equation PI-11 & $\mathrm{N}_{\text {excreted }}(\mathrm{kg})=\mathrm{N}_{\text {intake }}-\mathrm{N}_{\text {retention }}$ \\
\hline Equation PI-12 & $\mathrm{P}_{\text {excreted }}(\mathrm{kg})=\mathrm{P}_{\text {intake }}-\mathrm{P}_{\text {retention }}$ \\
\hline Equation FA-13 & $\mathrm{Cu}_{\text {excreted }}(\mathrm{kg})=\mathrm{Cu}_{\text {intake }}-\mathrm{Cu}_{\text {retention }}$ \\
\hline Equation FA-14 & $\mathrm{Zn}_{\text {excreted }}(\mathrm{kg})=\mathrm{Zn}_{\text {intake }}-\mathrm{Zn}_{\text {retention }}$ \\
\hline $\begin{array}{l}\text { Equation PI-15a } \\
\text { (growing phase) }\end{array}$ & $\mathrm{CH}_{4 \text { enteric }}(\mathrm{kg})=(\operatorname{ResD} \times 670) / 5.665 \mathrm{e}^{7}$ \\
\hline $\begin{array}{l}\text { Equation PI-15b } \\
\text { (sows) }\end{array}$ & $\mathrm{CH}_{4 \text { enteric }}(\mathrm{kg})=(\mathrm{ResD} \times 1340) / 5.665 \mathrm{e}^{7}$ \\
\hline Equation PI-16 & $\mathrm{CH}_{4 \text { manure }}(\mathrm{kg})=\mathrm{VS} \times \mathrm{Bo} \times \mathrm{MCF} \times 0.662$ \\
\hline \multirow[t]{2}{*}{ Equation PI-17 } & $\mathrm{N}_{2} \mathrm{O}_{\text {manure }}(\mathrm{kg})=\mathrm{N}_{\text {excreted }} \times\left(1-\mathrm{R}_{\mathrm{MMS}}\right) \times \mathrm{EF}_{\mathrm{MMS}} \times 44 / 28$ \\
\hline & Intensity \\
\hline Equation PI-18 & $\mathrm{N}_{\text {excreted }}$ Intensity $(\mathrm{kg} / \mathrm{kg}$ live weight $)=\mathrm{N}_{\text {excreted }} / \mathrm{TWG}$ \\
\hline Equation PI-19 & $\mathrm{P}_{\text {excreted }}$ Intensity $(\mathrm{kg} / \mathrm{kg}$ live weight $)=\mathrm{P}_{\text {excreted }} / \mathrm{TWG}$ \\
\hline Equation FA-20 & $\mathrm{Cu}_{\text {excreted }}$ Intensity $(\mathrm{kg} / \mathrm{kg}$ live weight $)=\mathrm{Cu}_{\text {excreted }} / \mathrm{TWG}$ \\
\hline Equation FA-21 & $\mathrm{Zn}_{\text {excreted }}$ Intensity $(\mathrm{kg} / \mathrm{kg}$ live weight $)=\mathrm{Zn}_{\text {excreted }} / \mathrm{TWG}$ \\
\hline Equation PI-22a & $\mathrm{CH}_{4 \text { enteric }}$ Intensity $(\mathrm{kg} / \mathrm{kg}$ live weight $)=\mathrm{CH}_{4 \text { enteric }} / \mathrm{TWG}$ \\
\hline Equation PI-22b & $\mathrm{CH}_{4 \text { enteric }}$ Intensity $(\mathrm{kg} / \mathrm{kg}$ live weight $)=\mathrm{CH}_{\text {4enteric }} / \mathrm{TWG}$ \\
\hline Equation PI-23 & $\mathrm{CH}_{4 \text { manure }}$ Intensity $(\mathrm{kg} / \mathrm{kg}$ live weight $)=\mathrm{CH}_{4 \text { manure }} / \mathrm{TWG}$ \\
\hline Equation PI-24 & $\mathrm{N}_{2} \mathrm{O}_{\text {manure }}$ Intensity $(\mathrm{kg} / \mathrm{kg}$ live weight $)=\mathrm{N}_{2} \mathrm{O}_{\text {manure }} / \mathrm{TWG}$ \\
\hline
\end{tabular}

Note: Subscript $\mathrm{Ph}$ means the growing phase (e.g. $\mathrm{CP}_{\mathrm{Ph}}$ represents the crude protein content of the feed during a specific growing phase such as starter).

\section{Feed additive scenarios}

Tables 28-32 provide the changes in the equations linked to the effect of the feed additives or a combination of feed additives on the parameters. Each table provides information on the potential effects of the feed additives or the combinations of feed additives (subsection 6.10.3 [i-iii]) as follows:

- modification of feed composition (Table 28)

- feed efficiency (Tables 29, 30 and 31)

- emission factors (Table 32) 
When the change in the equations used as a basis for the calculation (upper part of the tables) modifies the calculated impact, the corresponding equations are also indicated (lower part of the tables). As an example, when the concentration of nitrogen is changed in the diet (use of the factor $\Phi_{\text {nc }}$ ), the result of both the $N_{\text {intake }}$ and the $\mathrm{N}_{\text {excreted }}$ is changed. Hence these equations are also indicated. It should be noted that the factor might be different for the changes observed (e.g. $\Phi_{\mathrm{nc}}$ can be 1.05 for change in protein concentration and 0.98 for change in phosphorus concentration).

Table 28. Adaptation of equations for pigs (change in feed composition)

\begin{tabular}{|c|c|}
\hline & Basis for calculation \\
\hline Equation FA-1 & $\mathrm{N}_{\text {intake }}\left(\Phi_{\mathrm{nc}}\right)(\mathrm{kg})=\Sigma\left(\mathrm{FI}_{\mathrm{Ph}} \times\left(\% \mathrm{CP}_{\mathrm{Ph}} \times \Phi_{\mathrm{nc}}\right) / 100\right) / 6.25$ \\
\hline Equation FA-3 & $\mathrm{P}_{\text {intake }}\left(\Phi_{\mathrm{nc}}\right)(\mathrm{kg})=\Sigma\left(\mathrm{FI}_{\mathrm{Ph}} \times \% \mathrm{P}_{\text {totalPh }} \times \Phi_{\mathrm{nc}}\right) / 100$ \\
\hline Equation FA-5 & $\mathrm{Cu}_{\text {intake }}\left(\Phi_{\mathrm{nc}}\right)(\mathrm{kg})=\Sigma\left(\mathrm{FI}_{\mathrm{Ph}} \times \% \mathrm{Cu}_{\mathrm{Ph}} \times \Phi_{\mathrm{nc}}\right) / 100$ \\
\hline \multirow[t]{3}{*}{ Equation FA-7 } & $\mathrm{Zn}_{\text {intake }}\left(\Phi_{\mathrm{nc}}\right)(\mathrm{kg})=\Sigma\left(\mathrm{FI}_{\mathrm{Ph}} \times \% \mathrm{Zn}_{\mathrm{Ph}} \times \Phi_{\mathrm{nc}}\right) / 100$ \\
\hline & Calculated impacts \\
\hline & Total \\
\hline Equation PI-11 & $\mathrm{N}_{\text {excreted }}\left(\Phi_{\mathrm{nc}}\right)(\mathrm{kg})=\mathrm{N}_{\text {intake }}\left(\Phi_{\mathrm{nc}}\right)-\mathrm{N}_{\text {retention }}$ \\
\hline Equation PI-12 & $\mathrm{P}_{\text {excreted }}\left(\Phi_{\mathrm{nc}}\right)(\mathrm{kg})=\mathrm{P}_{\text {intake }}\left(\Phi_{\mathrm{nc}}\right)-\mathrm{P}_{\text {retention }}$ \\
\hline Equation FA-13 & $\mathrm{Cu}_{\text {excreted }}\left(\Phi_{\mathrm{nc}}\right)(\mathrm{kg})=\mathrm{Cu}_{\text {intake }}\left(\Phi_{\mathrm{nc}}\right)-\mathrm{Cu}_{\text {retention }}$ \\
\hline Equation FA-14 & $\mathrm{Zn}_{\text {excreted }}\left(\Phi_{\mathrm{nc}}\right)(\mathrm{kg})=\mathrm{Zn}_{\text {intake }}\left(\Phi_{\mathrm{nc}}\right)-\mathrm{Zn}_{\text {retention }}$ \\
\hline \multirow[t]{2}{*}{ Equation PI-17 } & $\mathrm{N}_{2} \mathrm{O}_{\text {manure }}\left(\Phi_{\mathrm{nc}}\right)(\mathrm{kg})=\mathrm{N}_{\text {excreted }}\left(\Phi_{\mathrm{nc}}\right) \times\left(1-\mathrm{R}_{\mathrm{MMS}}\right) \times \mathrm{EF}_{\mathrm{MMS}} \times 44 / 28$ \\
\hline & Intensity \\
\hline Equation PI-18 & $\mathrm{N}_{\text {excreted }}$ Intensity $\left(\Phi_{\mathrm{nc}}\right)(\mathrm{kg} / \mathrm{kg}$ live weight $)=\mathrm{N}_{\text {excreted }}\left(\Phi_{\mathrm{nc}}\right) / \mathrm{TWG}$ \\
\hline Equation PI-19 & $\mathrm{P}_{\text {excreted }}$ Intensity $\left(\Phi_{\mathrm{nc}}\right)(\mathrm{kg} / \mathrm{kg}$ live weight $)=\mathrm{P}_{\text {excreted }}\left(\Phi_{\mathrm{nc}}\right) / \mathrm{TWG}$ \\
\hline Equation FA-20 & $\mathrm{Cu}_{\text {excreted }}$ Intensity $\left(\Phi_{\mathrm{nc}}\right)(\mathrm{kg} / \mathrm{kg}$ live weight $)=\mathrm{Cu}_{\text {excreted }}\left(\Phi_{\mathrm{nc}}\right) / \mathrm{TWG}$ \\
\hline Equation FA-21 & $\mathrm{Zn}_{\text {excreted }}$ Intensity $\left(\Phi_{\mathrm{nc}}\right)(\mathrm{kg} / \mathrm{kg}$ live weight $)=\mathrm{Zn}_{\text {excreted }}\left(\Phi_{\mathrm{nc}}\right) / \mathrm{TWG}$ \\
\hline Equation PI-24 & $\mathrm{N}_{2} \mathrm{O}_{\text {manure }}$ Intensity $\left(\Phi_{\mathrm{nc}}\right)(\mathrm{kg} / \mathrm{kg}$ live weight $)=\mathrm{N}_{2} \mathrm{O}_{\text {manure }}\left(\Phi_{\mathrm{nc}}\right) / \mathrm{TWG}$ \\
\hline
\end{tabular}

Note: $\Phi_{\mathrm{nc}}=$ change in feed composition (protein, phosphorus, copper and zinc content); subscript $\mathrm{Ph}$ means the growing phase (e.g. $\mathrm{CP}_{\mathrm{Ph}}$ represent the crude protein content of the feed during a specific growing phase such as starter).

When a feed additive or combination of feed additives modifies the feed efficiency of pigs, it could be through a modification of one or more of the following:

- feed intake $\left(\Phi_{\mathrm{fi}}\right)$ (Table 29)

- weight gain $\left(\Phi_{\mathrm{wg}}\right)$ (Table 30$)$

- modification of the weight gain composition $\left(\Phi_{\mathrm{wgc}}\right)$ (Table 31)

In the case that the feed additive or the combination of feed additives has an impact on more than one of the above-mentioned parameters, it is advised to combine the different impact accordingly. For example, if the feed additive or combination of feed additives modifies the feed intake $\left(\Phi_{\mathrm{fi}}\right)$ and the weight gain $\left(\Phi_{\mathrm{wg}}\right)$, the nitrogen balance will be recalculated as follows:

- $\mathrm{N}_{\text {intake }}\left(\Phi_{\mathrm{fi}}\right)(\mathrm{kg})=\Sigma\left(\mathrm{FI}_{\mathrm{Ph}} \times \Phi_{\mathrm{fi}} \times\left(\% \mathrm{CP}_{\mathrm{Ph}} / 100\right)\right) / 6.25$ (Equation FA-1 adapted)

- $\mathrm{N}_{\text {retention }}\left(\Phi_{\mathrm{wg}}\right)(\mathrm{kg})=\left(\mathrm{TWG} \times \Phi_{\mathrm{wg}} \times \%\right.$ Protein in tissues/100)/6.25 (Equation

FA-2 adapted)

This will lead to a modification of the nitrogen excretion. 
Table 29: Adaptation of equations for pigs (change in feed intake)

\begin{tabular}{|c|c|}
\hline & Basis for calculation \\
\hline Equation FA-1 & $\mathrm{N}_{\text {intake }}\left(\Phi_{\mathrm{fi}}\right)(\mathrm{kg})=\Sigma\left(\mathrm{FI}_{\mathrm{Ph}} \times \Phi_{\mathrm{fi}} \times\left(\% \mathrm{CP}_{\mathrm{Ph}} / 100\right)\right) / 6.25$ \\
\hline Equation FA-3 & $\mathrm{P}_{\text {intake }}\left(\Phi_{\mathrm{fi}}\right)(\mathrm{kg})=\Sigma\left(\mathrm{FI}_{\mathrm{Ph}} \times \Phi_{\mathrm{fi}} \times \% \mathrm{P}_{\text {totalPh }}\right) / 100$ \\
\hline Equation FA-5 & $\mathrm{Cu}_{\text {intake }}\left(\Phi_{\mathrm{fi}}\right)(\mathrm{kg})=\Sigma\left(\mathrm{FI}_{\mathrm{Ph}} \times \Phi_{\mathrm{fi}} \times \% \mathrm{Cu}_{\mathrm{Ph}}\right) / 100$ \\
\hline Equation FA-7 & $\mathrm{Zn}_{\text {intake }}\left(\Phi_{\mathrm{fi}}\right)(\mathrm{kg})=\Sigma\left(\mathrm{FI}_{\mathrm{Ph}} \times \Phi_{\mathrm{fi}} \times \% \mathrm{Zn}_{\mathrm{Ph}}\right) / 100$ \\
\hline Equation PI-8 & $\mathrm{VS}\left(\Phi_{\mathrm{fi}}\right)(\mathrm{kg})=\Sigma\left(\mathrm{FI}_{\mathrm{Ph}} \times \Phi_{\mathrm{fi}} \times(1-\mathrm{DMD}) \times(1-\mathrm{A})+\mathrm{VS}_{\mathrm{WF}}\right)$ \\
\hline \multirow[t]{3}{*}{ Equation PI-9 } & $\mathrm{VS}_{\mathrm{WF}}\left(\Phi_{\mathrm{fi}}\right)(\mathrm{kg})=\Sigma\left(\mathrm{FI}_{\mathrm{Ph}} \times \Phi_{\mathrm{fi}} \times(1-\mathrm{A}) \times \mathrm{WF}_{\mathrm{Ph}}\right)$ \\
\hline & Calculated impacts \\
\hline & Total \\
\hline Equation PI-11 & $\mathrm{N}_{\text {excreted }}\left(\Phi_{\mathrm{fi}}\right)(\mathrm{kg})=\mathrm{N}_{\text {intake }}\left(\Phi_{\mathrm{fi}}\right)-\mathrm{N}_{\text {retention }}$ \\
\hline Equation PI-12 & $\mathrm{P}_{\text {excrete }}\left(\Phi_{\mathrm{fi}}\right)(\mathrm{kg})=\mathrm{P}_{\text {intake }}\left(\Phi_{\mathrm{fi}}\right)-\mathrm{P}_{\text {retention }}$ \\
\hline Equation FA-13 & $\mathrm{Cu}_{\text {excrete }}\left(\Phi_{\mathrm{f}}\right)(\mathrm{kg})=\mathrm{Cu}_{\text {intake }}\left(\Phi_{\mathrm{fi}}\right)-\mathrm{Cu}_{\text {retention }}$ \\
\hline Equation FA-14 & $\mathrm{Zn}_{\text {excrete }}\left(\Phi_{\mathrm{fi}}\right)(\mathrm{kg})=\mathrm{Zn}_{\text {intake }}\left(\Phi_{\mathrm{f}}\right)-\mathrm{Zn}_{\text {retention }}$ \\
\hline Equation FA-16 & $\mathrm{CH}_{4 \text { manure }}\left(\Phi_{\mathrm{fi}}\right)(\mathrm{kg})=\mathrm{VS} \times \mathrm{Bo} \times \mathrm{MCF} \times 0.662$ \\
\hline \multirow[t]{2}{*}{ Equation FA-17 } & $\mathrm{N}_{2} \mathrm{O}_{\text {manure }}\left(\Phi_{\mathrm{fi}}\right)=\mathrm{N}_{\text {excreted }}\left(\Phi_{\mathrm{fi}}\right) \times\left(1-\mathrm{R}_{\mathrm{MMS}}\right) \times \mathrm{EF}_{\mathrm{MMS}} \times 44 / 28$ \\
\hline & Intensity \\
\hline Equation PI-18 & $\mathrm{N}_{\text {excreted }}$ Intensity $\left(\Phi_{\mathrm{fi}}\right)(\mathrm{kg} / \mathrm{kg}$ live weight $)=\mathrm{N}_{\text {excreted }}\left(\Phi_{\mathrm{fi}}\right) / \mathrm{TWG}$ \\
\hline Equation PI-19 & $\mathrm{P}_{\text {excreted }}$ Intensity $\left(\Phi_{\mathrm{fi}}\right)(\mathrm{kg} / \mathrm{kg}$ live weight $)=\mathrm{P}_{\text {excreted }}\left(\Phi_{\mathrm{fi}}\right) / \mathrm{TWG}$ \\
\hline Equation FA-20 & $\mathrm{Cu}_{\text {excreted }}$ Intensity $\left(\Phi_{\mathrm{fi}}\right)(\mathrm{kg} / \mathrm{kg}$ live weight $)=\mathrm{Cu}_{\text {excreted }}\left(\Phi_{\mathrm{fi}}\right) / \mathrm{TWG}$ \\
\hline Equation FA-21 & $\mathrm{Zn}_{\text {excreted }}$ Intensity $\left(\Phi_{\mathrm{fi}}\right)(\mathrm{kg} / \mathrm{kg}$ live weight $)=\mathrm{Zn}_{\text {excreted }}\left(\Phi_{\mathrm{fi}}\right) / \mathrm{TWG}$ \\
\hline Equation PI-23 & $\mathrm{CH}_{4 \text { manure }}$ Intensity $\left(\Phi_{\mathrm{fi}}\right)(\mathrm{kg} / \mathrm{kg}$ live weight $)=\mathrm{CH}_{4 \text { manure }}\left(\Phi_{\mathrm{fi}}\right) / \mathrm{TWG}$ \\
\hline Equation PI-24 & $\mathrm{N}_{2} \mathrm{O}_{\text {manure }}$ Intensity $\left(\Phi_{\mathrm{fi}}\right)(\mathrm{kg} / \mathrm{kg}$ live weight $)=\mathrm{N}_{2} \mathrm{O}_{\text {manure }}\left(\Phi_{\mathrm{fi}}\right) / \mathrm{TWG}$ \\
\hline
\end{tabular}

Note: $\Phi_{\mathrm{fi}}=$ change in feed intake; subscript $\mathrm{Ph}$ means the growing phase (e.g. $\mathrm{CP}_{\mathrm{Ph}}$ represents the crude protein content of the feed during a specific growing phase such as starter).

In the case of a modification of the animal performance, the total weight gain is modified as follows:

TWG $\left(\Phi_{\mathrm{gp}}\right)=\mathrm{TWG} \times \Phi_{\mathrm{gp}}$

Hence the emission intensity is modified.

Table 30: Adaptation of equations for pigs (change in growth performance)

\begin{tabular}{lc} 
Equation FA-2 & $\mathrm{N}_{\text {retention }}\left(\Phi_{\mathrm{gp}}\right)(\mathrm{kg})=\left(\mathrm{TWG} \times \Phi_{\mathrm{gp}} \times \%\right.$ Protein in tissues/100)/6.25 \\
\hline Equation FA-4 & $\mathrm{P}_{\text {retention }}\left(\Phi_{\mathrm{gp}}\right)(\mathrm{kg})=\mathrm{TWG} \times \Phi_{\mathrm{gp}} \times \%$ in tissues and bones $/ 100$ \\
\hline Equation FA-6 & $\mathrm{Cu}_{\text {retention }}\left(\Phi_{\mathrm{gp}}\right)(\mathrm{kg})=\mathrm{TWG} \times \Phi_{\mathrm{gp}} \times \% \mathrm{Cu}$ in tissues and bones/100 \\
\hline Equation FA-8 & $\mathrm{Zn}_{\text {retention }}\left(\Phi_{\mathrm{gp}}\right)(\mathrm{kg})=\mathrm{TWG} \times \Phi_{\mathrm{gp}} \times \% \mathrm{Zn}$ in tissues and bones \\
& Calculated impacts \\
\hline Equation PI-11 & Total \\
\hline Equation PI-12 & $\mathrm{N}_{\text {excreted }}\left(\Phi_{\mathrm{gp}}\right)(\mathrm{kg})=\mathrm{N}_{\text {intake }}-\mathrm{N}_{\text {retention }}\left(\Phi_{\mathrm{gp}}\right)$ \\
\hline Equation FA-13 & $\mathrm{P}_{\text {excreted }}\left(\Phi_{\mathrm{gp}}\right)(\mathrm{kg})=\mathrm{P}_{\text {intake }}-\mathrm{P}_{\text {retention }}\left(\Phi_{\mathrm{gp}}\right)$ \\
\hline Equation FA-14 & $\mathrm{Cu}$ excreted $\left(\Phi_{\mathrm{gp}}\right)(\mathrm{kg})=\mathrm{Cu}_{\text {intake }}-\mathrm{Cu}_{\text {retention }}\left(\Phi_{\mathrm{gp}}\right)$ \\
\hline Equation PI-17 & $\mathrm{Zn}_{\text {excreted }}\left(\Phi_{\mathrm{gp}}\right)(\mathrm{kg})=\mathrm{Zn}_{\text {intake }}-\mathrm{Zn}_{\text {retention }}\left(\Phi_{\mathrm{gp}}\right)$ \\
\hline
\end{tabular}


Environmental performance of feed additives in livestock supply

\begin{tabular}{lc}
\hline & Intensity \\
\hline Equation PI-18 & $\mathrm{N}_{\text {excreted }}$ Intensity $\left(\Phi_{\mathrm{gp}}\right)(\mathrm{kg} / \mathrm{kg}$ live weight $)=\mathrm{N}_{\text {excreted }}\left(\Phi_{\mathrm{gp}}\right) / \mathrm{TWG}\left(\Phi_{\mathrm{gp}}\right)$ \\
\hline Equation PI-19 & $\mathrm{P}_{\text {excreted }}$ Intensity $\left(\Phi_{\mathrm{gp}}\right)(\mathrm{kg} / \mathrm{kg}$ live weight $)=\mathrm{P}_{\text {excreted }}\left(\Phi_{\mathrm{gp}}\right) / \mathrm{TWG}\left(\Phi_{\mathrm{gp}}\right)$ \\
\hline Equation FA-20 & $\mathrm{Cu}_{\text {excreed }}$ Intensity $\left(\Phi_{\mathrm{gp}}\right)(\mathrm{kg} / \mathrm{kg}$ live weight $)=\mathrm{Cu}_{\text {excreted }}\left(\Phi_{\mathrm{gp}}\right) / \mathrm{TWG}\left(\Phi_{\mathrm{gp}}\right)$ \\
\hline Equation FA-21 & $\mathrm{Zn}_{\text {excreted }}$ Intensity $\left(\Phi_{\mathrm{gp}}\right)(\mathrm{kg} / \mathrm{kg}$ live weight $)=\mathrm{Zn}_{\text {excreted }}\left(\Phi_{\mathrm{gp}}\right) / \mathrm{TWG}\left(\Phi_{\mathrm{gp}}\right)$ \\
\hline Equation FI-22a & $\mathrm{CH}_{4 \text { enteric }}$ Intensity $\left(\Phi_{\mathrm{gp}}\right)(\mathrm{kg} / \mathrm{kg}$ live weight $)=\mathrm{CH}_{4 \text { enteric }} / \mathrm{TWG}\left(\Phi_{\mathrm{gp}}\right)$ \\
\hline Equation FI-22b & $\mathrm{CH}_{4 \text { enteric }}$ Intensity $\left(\Phi_{\mathrm{gp}}\right)(\mathrm{kg} / \mathrm{kg}$ live weight $)=\mathrm{CH}_{\text {4enteric }} / \mathrm{TWG}\left(\Phi_{\mathrm{gp}}\right)$ \\
\hline Equation FI-23 & $\mathrm{CH}_{4 \text { manure }}$ Intensity $\left(\Phi_{\mathrm{gp}}\right)(\mathrm{kg} / \mathrm{kg}$ live weight $)=\mathrm{CH}_{4 \text { manure }} / \mathrm{TWG}\left(\Phi_{\mathrm{gp}}\right)$ \\
\hline Equation FI-24 & $\mathrm{N}_{2} \mathrm{O}_{\text {manure }}$ Intensity $\left(\Phi_{\mathrm{gp}}\right)(\mathrm{kg} / \mathrm{kg}$ live weight $)=\mathrm{N}_{2} \mathrm{O}_{\text {manure }}\left(\Phi_{\mathrm{gp}}\right) / \mathrm{TWG}\left(\Phi_{\mathrm{gp}}\right)$ \\
\hline
\end{tabular}

Note: $\Phi_{\mathrm{gp}}=$ change in growth performance.

When the feed additive or the combination of feed additives modifies the body weight gain composition, the factor $\Phi_{\text {bwc }}$ is used in the equations (Table 31). It should be noted that the factor might be different for the changes observed (e.g. $\Phi_{\text {bwc }}$ can be 1.05 for change in protein concentration and 0.98 for change in phosphorus concentration).

Table 31: Adaptation of equations for pigs (change in body weight gain composition)

\begin{tabular}{|c|c|}
\hline & Basis for calculation \\
\hline Equation FA-2 & $\mathrm{N}_{\text {retention }}\left(\Phi_{\mathrm{bwc}}\right)(\mathrm{kg})=\left(\mathrm{TWG} \times \%\right.$ Protein in tissues $\left.\times \Phi_{\mathrm{bwc}} / 100\right) / 6.25$ \\
\hline Equation FA-4 & $\mathrm{P}_{\text {retention }}\left(\Phi_{\mathrm{bwc}}\right)(\mathrm{kg})=\mathrm{TWG} \times \% \mathrm{P}$ in tissues and bones $\times \Phi_{\mathrm{bwc}} / 100$ \\
\hline Equation FA-6 & $\mathrm{Cu}_{\text {retention }}\left(\Phi_{\mathrm{bwc}}\right)(\mathrm{kg})=\mathrm{TWG} \times \% \mathrm{Cu}$ in tissues and bones $\times \Phi_{\mathrm{bwc}} / 100$ \\
\hline \multirow[t]{3}{*}{ Equation FA-8 } & $\mathrm{Zn}_{\text {retention }}\left(\Phi_{\mathrm{bwc}}\right)(\mathrm{kg})=\mathrm{TWG} \times \% \mathrm{Zn}$ in tissues and bones $\times \Phi_{\mathrm{bwc}} / 100$ \\
\hline & Calculated impacts \\
\hline & Total \\
\hline Equation PI-11 & $\mathrm{N}_{\text {excreted }}\left(\Phi_{\text {bwc }}\right)(\mathrm{kg})=\mathrm{N}_{\text {intake }}-\mathrm{N}_{\text {retention }}\left(\Phi_{\text {bwc }}\right)$ \\
\hline Equation PI-12 & $P_{\text {excreted }}\left(\Phi_{\text {bwc }}\right)(\mathrm{kg})=P_{\text {intake }}-P_{\text {retention }}\left(\Phi_{\text {bwc }}\right)$ \\
\hline Equation FA-13 & $\mathrm{Cu}_{\text {excreted }}\left(\Phi_{\mathrm{bwc}}\right)(\mathrm{kg})=\mathrm{Cu}_{\text {intake }}-\mathrm{Cu}_{\text {retention }}\left(\Phi_{\mathrm{bwc}}\right)$ \\
\hline Equation FA-14 & $\mathrm{Zn}_{\text {excreted }}\left(\Phi_{\text {bwc }}\right)(\mathrm{kg})=\mathrm{Zn}_{\text {intake }}-\mathrm{Zn}_{\text {retention }}\left(\Phi_{\text {bwc }}\right)$ \\
\hline \multirow[t]{2}{*}{ Equation PI-17 } & $\mathrm{N}_{2} \mathrm{O}_{\text {manure }}\left(\Phi_{\mathrm{bwc}}\right)=\mathrm{N}_{\text {excreted }}\left(\Phi_{\mathrm{bwc}}\right) \times\left(1-\mathrm{R}_{\mathrm{MMS}}\right) \times \mathrm{EF}_{\mathrm{MMS}}(\%) \times 44 / 28$ \\
\hline & Intensity \\
\hline Equation PI-18 & $\mathrm{N}_{\text {excreted }}$ Intensity $\left(\Phi_{\mathrm{bwc}}\right)(\mathrm{kg} / \mathrm{kg}$ live weight $)=\mathrm{N}_{\text {excreted }}\left(\Phi_{\mathrm{bwc}}\right) / \mathrm{TWG}$ \\
\hline Equation PI-19 & $\mathrm{P}_{\text {excreted }}$ Intensity $\left(\Phi_{\text {bwc }}\right)(\mathrm{kg} / \mathrm{kg}$ live weight $)=\mathrm{P}_{\text {excreted }}\left(\Phi_{\text {bwc }}\right) / \mathrm{TWG}$ \\
\hline Equation FA-20 & $\mathrm{Cu}_{\text {excreted }}$ Intensity $\left(\Phi_{\mathrm{bwc}}\right)(\mathrm{kg} / \mathrm{kg}$ live weight $)=\mathrm{Cu}_{\text {excreted }}\left(\Phi_{\mathrm{bwc}}\right) / \mathrm{TWG}$ \\
\hline Equation FA-21 & $\mathrm{Zn}_{\text {excreted }}$ Intensity $\left(\Phi_{\mathrm{bwc}}\right)(\mathrm{kg} / \mathrm{kg}$ live weight $)=\mathrm{Zn}_{\text {excreted }}\left(\Phi_{\mathrm{bwc}}\right) / \mathrm{TWG}$ \\
\hline Equation PI-24 & $\mathrm{N}_{2} \mathrm{O}_{\text {manure }}$ Intensity $\left(\Phi_{\mathrm{bwc}}\right)(\mathrm{kg} / \mathrm{kg}$ live weight $)=\mathrm{N}_{2} \mathrm{O}_{\text {manure }}\left(\Phi_{\mathrm{bwc}}\right) / \mathrm{TWG}$ \\
\hline
\end{tabular}

Note: $\Phi_{\text {bwc }}=$ change in body weight gain composition.

When the feed additive or the combination has a direct effect on methane $\left(\mathrm{CH}_{4}\right)$ or $\mathrm{N}_{2} \mathrm{O}$ emissions, the factor $\Phi_{\mathrm{ef}}$ is used for the modification of the emission factor in the relevant equations. Although the factor is named in the same way in the equations $\left(\Phi_{\mathrm{ef}}\right)$, it will differ for the relevant emissions. 
Table 32: Adaptation of equations for pigs (change in emission factor)

\begin{tabular}{lc} 
& Calculated impacts \\
\hline Equation PI-16 & $\mathrm{CH}_{4 \text { manure }}\left(\Phi_{\mathrm{ef}}\right)(\mathrm{kg})=\mathrm{VS} \times \mathrm{Bo} \times \mathrm{MCF} \times \Phi_{\mathrm{ef}} \times 0.662$ \\
\hline Equation PI-17 & $\mathrm{N}_{2} \mathrm{O}_{\text {manure }}\left(\Phi_{\mathrm{ef}}\right)(\mathrm{kg})=\mathrm{N}_{\text {excreted }} \times\left(1-\mathrm{R}_{\mathrm{MMS}}\right) \times \mathrm{EF}_{\mathrm{MMS}} \times \Phi_{\mathrm{ef}} \times 44 / 28$ \\
\hline Equation PI-23 & Intensity \\
\hline Equation PI-24 & $\mathrm{CH}_{\text {4manure }}$ Intensity $\left(\Phi_{\mathrm{ef}}\right)(\mathrm{kg} / \mathrm{kg}$ live weight $)=\mathrm{CH}_{4 \text { manure }}\left(\Phi_{\mathrm{ef}}\right) / \mathrm{TWG}$ \\
\hline
\end{tabular}

Note: $\Phi_{\mathrm{ef}}=$ change in emission factor.

\section{vi. Poultry (broiler) \\ Baseline scenario}

Table 33 lists the equations relevant for the evaluation of the environmental impact of broilers for the baseline scenario. The equations originating from the LEAP poultry guidelines (FAO, 2016d) are noted "Equation PO-n" (e.g. Equation PO-7). For consistency with the other species and while the detailed equations are not available in the poultry guidelines, additional equations are included, noted "Equation FA-n" (e.g. Equation FA-1). The calculated impacts will be the comparison point for the feed additive scenario. Definitions of parameters and variables used in the equations are given in Table 2.

Broiler production comprises different phases (starter, finisher). When calculating the impact, the sum of the impacts during the different phases should be calculated.

Table 33: Equations used for evaluating the baseline emissions for broilers

\begin{tabular}{|c|c|}
\hline & Basis for calculation \\
\hline Equation FA-1 & $\mathrm{P}_{\text {intake }}(\mathrm{kg})=\Sigma\left(\mathrm{FI}_{\mathrm{Ph}} \times \% \mathrm{P}_{\text {totalPh }}\right) / 100$ \\
\hline Equation FA-2 & $\mathrm{P}_{\text {retention }}(\mathrm{kg})=\mathrm{TWG} \times \% \mathrm{P}$ in tissues and bones $/ 100$ \\
\hline Equation FA-3 & $\mathrm{Cu}_{\text {intake }}(\mathrm{kg})=\Sigma\left(\mathrm{FI}_{\mathrm{Ph}} \times \% \mathrm{Cu}_{\mathrm{Ph}}\right) / 100$ \\
\hline Equation FA-4 & $\mathrm{Cu}_{\text {retention }}(\mathrm{kg})=\mathrm{TWG} \times \% \mathrm{Cu}$ in tissues and bones $/ 100$ \\
\hline Equation FA-5 & $\mathrm{Zn}_{\text {intake }}(\mathrm{kg})=\Sigma\left(\mathrm{FI}_{\mathrm{Ph}} \times \% \mathrm{Zn}_{\mathrm{Ph}}\right) / 100$ \\
\hline Equation FA-6 & $\mathrm{Zn}_{\text {retention }}(\mathrm{kg})=\mathrm{TWG} \times \% \mathrm{Zn}$ in tissues and bones $/ 100$ \\
\hline \multirow[t]{3}{*}{ Equation $\mathrm{PO}-7$} & $\mathrm{VS}(\mathrm{kg})=\Sigma\left(\mathrm{FI}_{\mathrm{Ph}} \times\left(1-\mathrm{DMD}_{\mathrm{Ph}}\right) \times(1-\mathrm{A})\right)$ \\
\hline & Calculated impacts \\
\hline & Total \\
\hline Equation $\mathrm{PO}-8$ & $\mathrm{~N}_{\text {excreted }}(\mathrm{kg})=\Sigma\left(\mathrm{FI}_{\mathrm{Ph}} \times \% \mathrm{CP}_{\mathrm{Ph}} / 100\right) / 6.25 \times(1-0.602)$ \\
\hline Equation FA-9 & $\mathrm{P}_{\text {excreted }}(\mathrm{kg})=\mathrm{P}_{\text {intake }}-\mathrm{P}_{\text {retention }}$ \\
\hline Equation FA-10 & $\mathrm{Cu}_{\text {excreted }}(\mathrm{kg})=\mathrm{Cu}_{\text {intake }}-\mathrm{Cu}_{\text {retention }}$ \\
\hline Equation FA-11 & $\mathrm{Zn}_{\text {excreted }}(\mathrm{kg})=\mathrm{Zn}_{\text {intake }}-\mathrm{Zn}_{\text {retention }}$ \\
\hline Equation PO-12 & $\mathrm{CH}_{4 \text { manure }}(\mathrm{kg})=\mathrm{VS} \times \mathrm{Bo} \times \mathrm{MCF} \times 0.662$ \\
\hline \multirow[t]{2}{*}{ Equation PO-13 } & $\mathrm{N}_{2} \mathrm{O}_{\text {manure }}(\mathrm{kg})=\mathrm{N}_{\text {excreted }} \times \mathrm{EF}_{\text {MMS }} \times 44 / 28$ \\
\hline & Intensity \\
\hline Equation PO-14 & $\mathrm{N}_{\text {excreted }}$ Intensity $(\mathrm{kg} / \mathrm{kg}$ live weight $)=\mathrm{N}_{\text {excreted }} / \mathrm{TWG}$ \\
\hline Equation FA-15 & $\mathrm{P}_{\text {excreted }}$ Intensity $(\mathrm{kg} / \mathrm{kg}$ live weight $)=\mathrm{P}_{\text {excreted }} / \mathrm{TWG}$ \\
\hline Equation FA-16 & $\mathrm{Cu}_{\text {excreted }}$ Intensity $(\mathrm{kg} / \mathrm{kg}$ live weight $)=\mathrm{Cu}_{\text {excreted }} / \mathrm{TWG}$ \\
\hline Equation FA-17 & $\mathrm{Zn}_{\text {excreted }}$ Intensity $(\mathrm{kg} / \mathrm{kg}$ live weight $)=\mathrm{Zn}_{\text {excreted }} / \mathrm{TWG}$ \\
\hline Equation PO-18 & $\mathrm{CH}_{4 \text { manure }}$ Intensity $(\mathrm{kg} / \mathrm{kg}$ live weight $)=\mathrm{CH}_{4 \text { manure }} / \mathrm{TWG}$ \\
\hline Equation PO-19 & $\mathrm{N}_{2} \mathrm{O}_{\text {manure }}$ Intensity $(\mathrm{kg} / \mathrm{kg}$ live weight $)=\mathrm{N}_{2} \mathrm{O}_{\text {manure }} / \mathrm{TWG}$ \\
\hline
\end{tabular}




\section{Feed additive scenarios}

Tables 34-38 provide the changes in the equations linked to the effect of the feed additives or a combination of feed additives on the parameters. Each table provides information on the potential effects of the feed additives or the combinations of feed additives (subsection 6.10.3 [i-iii]) as follows:

- modification of feed composition (Table 34)

- feed efficiency (Tables 35, 36, 37)

- emission factors (Table 38)

When the change in the equations used as a basis for the calculation (upper part of the tables) modifies the calculated impact, the corresponding equations are also indicated (lower part of the tables). For example, when the concentration of nitrogen is changed in the diet (use of the factor $\Phi_{\mathrm{nc}}$ ), the result of both the $\mathrm{N}_{\text {intake }}$ and the $\mathrm{N}_{\text {excreted }}$ is changed. Hence these equations are also indicated. It should be noted that the factor might be different depending on the changes observed (e.g. $\Phi_{\mathrm{nc}}$ can be 1.05 for change in protein concentration and 0.98 for change in phosphorus concentration).

Table 34: Adaptation of equations for broilers (change in feed composition)

\begin{tabular}{|c|c|}
\hline & Basis for calculation \\
\hline Equation FA-1 & $\mathrm{P}_{\text {intake }}\left(\Phi_{\mathrm{nc}}\right)(\mathrm{kg})=\Sigma\left(\mathrm{FI}_{\mathrm{Ph}} \times \% \mathrm{P}_{\text {totalPh }} \times \Phi_{\mathrm{nc}}\right) / 100$ \\
\hline Equation FA-3 & $\mathrm{Cu}_{\text {intake }}\left(\Phi_{\mathrm{nc}}\right)(\mathrm{kg})=\Sigma\left(\mathrm{FI}_{\mathrm{Ph}} \times \% \mathrm{Cu}_{\mathrm{Ph}} \times \Phi_{\mathrm{nc}}\right) / 100$ \\
\hline \multirow[t]{3}{*}{ Equation FA-5 } & $\mathrm{Zn}_{\text {intake }}\left(\Phi_{\mathrm{nc}}\right)(\mathrm{kg})=\Sigma\left(\mathrm{FI}_{\mathrm{Ph}} \times \% \mathrm{Zn}_{\mathrm{Ph}} \times \Phi_{\mathrm{nc}}\right) / 100$ \\
\hline & Calculated impacts \\
\hline & Total \\
\hline Equation PO-8 & $\mathrm{N}_{\text {excreted }}\left(\Phi_{\mathrm{nc}}\right)(\mathrm{kg})=\Sigma\left(\mathrm{FI}_{\mathrm{Ph}} \times \Phi_{\mathrm{nc}} \times \% \mathrm{CP}_{\mathrm{Ph}} \times \Phi_{\mathrm{nc}} / 100\right) / 6.25 \times(1-0.602)$ \\
\hline Equation FA-9 & $\mathrm{P}_{\text {excreted }}\left(\Phi_{\mathrm{nc}}\right)(\mathrm{kg})=\mathrm{P}_{\text {intake }}\left(\Phi_{\mathrm{nc}}\right)-\mathrm{P}_{\text {retention }}$ \\
\hline Equation FA-10 & $\mathrm{Cu}_{\text {excreted }}\left(\Phi_{\mathrm{nc}}\right)(\mathrm{kg})=\mathrm{Cu}_{\text {intake }}\left(\Phi_{\mathrm{nc}}\right)-\mathrm{Cu}_{\text {retention }}$ \\
\hline Equation FA-11 & $\mathrm{Zn}_{\text {excreted }}\left(\Phi_{\mathrm{nc}}\right)(\mathrm{kg})=\mathrm{Zn}_{\text {intake }}\left(\Phi_{\mathrm{nc}}\right)-\mathrm{Zn}_{\text {retention }}$ \\
\hline \multirow[t]{2}{*}{ Equation PO-13 } & $\mathrm{N}_{2} \mathrm{O}_{\text {manure }}\left(\Phi_{\mathrm{nc}}\right)(\mathrm{kg})=\mathrm{N}_{\text {excreted }}\left(\Phi_{\mathrm{nc}}\right) \times \mathrm{EF}_{\mathrm{MMS}} \times 44 / 28$ \\
\hline & Intensity \\
\hline Equation PO-14 & $\mathrm{N}_{\text {excreted }}$ Intensity $\left(\Phi_{\mathrm{nc}}\right)(\mathrm{kg} / \mathrm{kg}$ live weight $)=\mathrm{N}_{\text {excreted }}\left(\Phi_{\mathrm{nc}}\right) / \mathrm{TWG}$ \\
\hline Equation FA-15 & $\mathrm{P}_{\text {excreted }}$ Intensity $\left(\Phi_{\mathrm{nc}}\right)(\mathrm{kg} / \mathrm{kg}$ live weight $)=\mathrm{P}_{\text {excreted }}\left(\Phi_{\mathrm{nc}}\right) / \mathrm{TWG}$ \\
\hline Equation FA-16 & $\mathrm{Cu}_{\text {excreted }}$ Intensity $\left(\Phi_{\mathrm{nc}}\right)(\mathrm{kg} / \mathrm{kg}$ live weight $)=\mathrm{Cu}_{\text {excreted }}\left(\Phi_{\mathrm{nc}}\right) / \mathrm{TWG}$ \\
\hline Equation FA-17 & $\mathrm{Zn}_{\text {excreted }}\left(\Phi_{\mathrm{nc}}\right)$ Intensity $(\mathrm{kg} / \mathrm{kg}$ live weight $)=\mathrm{Zn}_{\text {excreted }}\left(\Phi_{\mathrm{nc}}\right) / \mathrm{TWG}$ \\
\hline Equation PO-19 & $\mathrm{N}_{2} \mathrm{O}_{\text {manure }}$ Intensity $\left(\Phi_{\mathrm{nc}}\right)(\mathrm{kg} / \mathrm{kg}$ live weight $)=\mathrm{N}_{2} \mathrm{O}_{\text {manure }}\left(\Phi_{\mathrm{nc}}\right) / \mathrm{TWG}$ \\
\hline
\end{tabular}

Note: $\Phi_{\mathrm{nc}}=$ change in feed composition (protein, phosphorus, copper and zinc content); subscript $\mathrm{Ph}$ means the growing phase (e.g. \% $\mathrm{Cu}_{\mathrm{Ph}}$ represents the copper content of the feed during a specific growing phase such as starter).

When a feed additive or combination of feed additives modifies the feed efficiency of broilers, it could be through a modification of one or more of the following:

- feed intake $\left(\Phi_{\mathrm{fi}}\right)($ Table 35$)$

- weight gain $\left(\Phi_{\mathrm{wg}}\right)$ (Table 36)

- modification of the weight gain composition $\left(\Phi_{\mathrm{wgc}}\right)$ (Table 37)

In the case that the feed additive or combination of feed additives has an impact on more than one of the above-mentioned parameters, it is advised to combine the different impact accordingly. For example, if the feed additive or combination of feed additives modifies the feed intake $\left(\Phi_{\mathrm{f}}\right)$ and the weight gain $\left(\Phi_{\mathrm{wg}}\right)$, the phosphorus balance will be recalculated as follows: 
- $\mathrm{P}_{\text {intake }}\left(\Phi_{\mathrm{fi}}\right)(\mathrm{kg})=\Sigma\left(\mathrm{FI}_{\mathrm{Ph}} \times \Phi_{\mathrm{fi}} \times\left(\% \mathrm{P}_{\text {totalPh }} / 100\right)\right)($ Equation FA-1 adapted $)$

- $\mathrm{P}_{\text {retention }}\left(\Phi_{\mathrm{wg}}\right)(\mathrm{kg})=\left(\mathrm{TWG} \times \Phi_{\mathrm{wg}} \times \%\right.$ P in tissues and bones/100) (Equation FA-2 adapted) This will lead to a modification of the phosphorus excretion.

Table 35: Adaptation of equations for broilers (change in feed intake)

\begin{tabular}{|c|c|}
\hline & Basis for calculation \\
\hline Equation FA-1 & $\mathrm{P}_{\text {intake }}\left(\Phi_{\mathrm{fi}}\right)(\mathrm{kg})=\Sigma\left(\mathrm{FI}_{\mathrm{Ph}} \times \Phi_{\mathrm{fi}} \times \% \mathrm{P}_{\text {totalPh }}\right) / 100$ \\
\hline Equation FA-3 & $\mathrm{Cu}_{\text {intake }}\left(\Phi_{\mathrm{fi}}\right)(\mathrm{kg})=\Sigma\left(\mathrm{FI}_{\mathrm{Ph}} \times \Phi_{\mathrm{fi}} \times \% \mathrm{Cu}_{\mathrm{Ph}}\right) / 100$ \\
\hline Equation FA-5 & $\mathrm{Zn}_{\text {intake }}\left(\Phi_{\mathrm{fi}}\right)(\mathrm{kg})=\Sigma\left(\mathrm{FI}_{\mathrm{Ph}} \times \Phi_{\mathrm{fi}} \times \% \mathrm{Zn}_{\mathrm{Ph}}\right) / 100$ \\
\hline \multirow[t]{3}{*}{ Equation PO-7 } & $\operatorname{VS}\left(\Phi_{\mathrm{fi}}\right)(\mathrm{kg})=\Sigma\left(\mathrm{FI}_{\mathrm{Ph}} \times \Phi_{\mathrm{fi}} \times\left(1-\mathrm{DMD}_{\mathrm{Ph}}\right) \times(1-\mathrm{A})\right)$ \\
\hline & Calculated impacts \\
\hline & Total \\
\hline Equation PO-8 & $\mathrm{N}_{\text {excreted }}\left(\Phi_{\mathrm{fi}}\right)(\mathrm{kg})=\Sigma\left(\mathrm{FI}_{\mathrm{Ph}} \times \Phi_{\mathrm{fi}} \times \% \mathrm{CP}_{\mathrm{Ph}} / 100\right) / 6.25 \times(1-0.602)$ \\
\hline Equation FA-9 & $\mathrm{P}_{\text {excreted }}\left(\Phi_{\mathrm{fi}}\right)(\mathrm{kg})=\mathrm{P}_{\text {intake }}\left(\Phi_{\mathrm{fi}}\right)-\mathrm{P}_{\text {retention }}$ \\
\hline Equation FA-10 & $\mathrm{Cu}_{\text {excreted }}\left(\Phi_{\mathrm{fi}}\right)(\mathrm{kg})=\mathrm{Cu}_{\text {intake }}\left(\Phi_{\mathrm{f}}\right)-\mathrm{Cu}_{\text {retention }}$ \\
\hline Equation FA-11 & $\mathrm{Zn}_{\text {excreted }}\left(\Phi_{\mathrm{fi}}\right)(\mathrm{kg})=\mathrm{Zn}_{\text {intake }}\left(\Phi_{\mathrm{fi}}\right)-\mathrm{Zn}_{\text {retention }}$ \\
\hline Equation PO-12 & $\mathrm{CH}_{4 \text { manure }}\left(\Phi_{\mathrm{fi}}\right)(\mathrm{kg})=\mathrm{VS}\left(\Phi_{\mathrm{fi}}\right) \times \mathrm{Bo} \times \mathrm{MCF} \times 0.662$ \\
\hline \multirow[t]{2}{*}{ Equation $\mathrm{PO}-13$} & $\mathrm{~N}_{2} \mathrm{O}_{\text {manure }}\left(\Phi_{\mathrm{fi}}\right)(\mathrm{kg})=\mathrm{N}_{\text {excreted }}\left(\Phi_{\mathrm{fi}}\right) \times \mathrm{EF}_{\mathrm{MMS}} \times 44 / 28$ \\
\hline & Intensity \\
\hline Equation PO-14 & $\mathrm{N}_{\text {excreted }}$ Intensity $\left(\Phi_{\mathrm{fi}}\right)(\mathrm{kg} / \mathrm{kg}$ live weight $)=\mathrm{N}_{\text {excreted }}\left(\Phi_{\mathrm{fi}}\right) / \mathrm{TWG}$ \\
\hline Equation FA-15 & $\mathrm{P}_{\text {excreted }} \operatorname{Intensity}\left(\Phi_{\mathrm{fi}}\right)(\mathrm{kg} / \mathrm{kg}$ live weight $)=\mathrm{P}_{\text {excreted }}\left(\Phi_{\mathrm{fi}}\right) / \mathrm{TWG}$ \\
\hline Equation FA-16 & $\mathrm{Cu}_{\text {excreted }}$ Intensity $\left(\Phi_{\mathrm{fi}}\right)(\mathrm{kg} / \mathrm{kg}$ live weight $)=\mathrm{Cu}_{\text {excreted }}\left(\Phi_{\mathrm{fi}}\right) / \mathrm{TWG}$ \\
\hline Equation FA-17 & $\mathrm{Zn}_{\text {excreted }}$ Intensity $\left(\Phi_{\mathrm{fi}}\right)(\mathrm{kg} / \mathrm{kg}$ live weight $)=\mathrm{Zn}_{\text {excreted }}\left(\Phi_{\mathrm{f}}\right) / \mathrm{TWG}$ \\
\hline Equation PO-18 & $\mathrm{CH}_{4 \text { manure }}$ Intensity $\left(\Phi_{\mathrm{fi}}\right)(\mathrm{kg} / \mathrm{kg}$ live weight $)=\mathrm{CH}_{4 \text { manure }}\left(\Phi_{\mathrm{fi}}\right) / \mathrm{TWG}$ \\
\hline Equation PO-19 & $\mathrm{N}_{2} \mathrm{O}_{\text {manure }}$ Intensity $\left(\Phi_{\mathrm{fi}}\right)(\mathrm{kg} / \mathrm{kg}$ live weight $)=\mathrm{N}_{2} \mathrm{O}_{\text {manure }}\left(\Phi_{\mathrm{fi}}\right) / \mathrm{TWG}$ \\
\hline
\end{tabular}

Note: $\Phi_{\mathrm{fi}}=$ change in feed intake; subscript $\mathrm{Ph}$ means the growing phase (e.g. \% $\mathrm{Cu}_{\mathrm{Ph}}$ represents the crude protein content of the feed during a specific growing phase such as starter).

In the case of a modification of the animal performance, the total weight gain is modified as follows:

$\operatorname{TWG}\left(\Phi_{\mathrm{gp}}\right)=\mathrm{TWG} \times \Phi_{\mathrm{gp}}$

Hence the emission intensity is modified.

Table 36: Adaptation of equations for broilers (change in growth performance)

\begin{tabular}{lc} 
Equation FA-2 & $\mathrm{P}_{\text {retention }}\left(\Phi_{\mathrm{gp}}\right)(\mathrm{kg})=\mathrm{TWG} \times \Phi_{\mathrm{gp}} \times \%$ P in tissues and bones/100 \\
\hline Equation FA-4 & $\mathrm{Cu}_{\text {retention }}\left(\Phi_{\mathrm{gp}}\right)(\mathrm{kg})=\mathrm{TWG} \times \Phi_{\mathrm{gp}} \times \% \mathrm{Cu}$ in tissues and bones $/ 100$ \\
\hline Equation FA-6 & $\mathrm{Zn}_{\text {retention }}\left(\Phi_{\mathrm{gp}}\right)(\mathrm{kg})=\mathrm{TWG} \times \Phi_{\mathrm{gp}} \times \% \mathrm{Zn}$ in tissues and bones $/ 100$ \\
& Calculated impacts \\
\hline Equation PO-8 & Total \\
\hline Equation FA-9 & $\mathrm{N}_{\text {excreted }}\left(\Phi_{\mathrm{gp}}\right)(\mathrm{kg})=\Sigma\left(\mathrm{FI} \mathrm{Ph}_{\mathrm{Ph}} \times \mathrm{CP}_{\mathrm{Ph}} / 100\right) / 6.25 \times\left(1-0.602 \times \Phi_{\mathrm{gp}}\right)$ \\
\hline Equation FA-10 & $\mathrm{P}_{\text {excreted }}\left(\Phi_{\mathrm{gp}}\right)(\mathrm{kg})=\mathrm{P}_{\text {intake }}-\mathrm{P}_{\text {retention }}\left(\Phi_{\mathrm{gp}}\right)$ \\
\hline Equation FA-11 & $\mathrm{Cu}_{\text {excreted }}\left(\Phi_{\mathrm{gp}}\right)(\mathrm{kg})=\mathrm{Cu}_{\text {intake }}-\mathrm{Cu}_{\text {retention }}\left(\Phi_{\mathrm{gp}}\right)$ \\
\hline
\end{tabular}


Environmental performance of feed additives in livestock supply

\begin{tabular}{lc}
\hline & Intensity \\
\hline Equation PO-14 & $\mathrm{N}_{\text {excreted }}$ Intensity $\left(\Phi_{\mathrm{gp}}\right)(\mathrm{kg} / \mathrm{kg}$ live weight $)=\mathrm{N}_{\text {excreted }}\left(\Phi_{\mathrm{gp}}\right) / \mathrm{TWG}\left(\Phi_{\mathrm{gp}}\right)$ \\
\hline Equation FA-15 & $\mathrm{P}_{\text {excreted }}$ Intensity $\left(\Phi_{\mathrm{gp}}\right)(\mathrm{kg} / \mathrm{kg}$ live weight $)=\mathrm{P}_{\text {excreted }}\left(\Phi_{\mathrm{gp}}\right) / \mathrm{TWG}\left(\Phi_{\mathrm{gp}}\right)$ \\
\hline Equation FA-16 & $\mathrm{Cu}_{\text {excreted }}$ Intensity $\left(\Phi_{\mathrm{gp}}\right)(\mathrm{kg} / \mathrm{kg}$ live weight $)=\mathrm{Cu}_{\text {excreted }}\left(\Phi_{\mathrm{gp}}\right) / \mathrm{TWG}\left(\Phi_{\mathrm{gp}}\right)$ \\
\hline Equation FA-17 & $\mathrm{Zn}_{\text {excreted }}$ Intensity $\left(\Phi_{\mathrm{gp}}\right)(\mathrm{kg} / \mathrm{kg}$ live weight $)=\mathrm{Zn}_{\text {excreted }}\left(\Phi_{\mathrm{gp}}\right) / \mathrm{TWG}\left(\Phi_{\mathrm{gp}}\right)$ \\
\hline Equation PO-18 & $\mathrm{CH}_{\text {4manure }}$ Intensity $\left(\Phi_{\mathrm{gp}}\right)(\mathrm{kg} / \mathrm{kg}$ live weight $)=\mathrm{CH}_{\text {4manure }} / \mathrm{TWG}\left(\Phi_{\mathrm{gp}}\right)$ \\
\hline Equation PO-19 & $\mathrm{N}_{2} \mathrm{O}_{\text {manure }}$ Intensity $\left(\Phi_{\mathrm{gp}}\right)(\mathrm{kg} / \mathrm{kg}$ live weight $)=\mathrm{N}_{2} \mathrm{O}_{\text {manure }} / \mathrm{TWG}\left(\Phi_{\mathrm{gp}}\right)$ \\
\hline
\end{tabular}

Note: $\Phi_{\mathrm{gp}}=$ change in growth performance.

When the feed additive or the combination of feed additives modifies the body weight gain composition, the factor $\Phi_{\mathrm{bwc}}$ is used in the equations (Table 37). It should be noted that the factor might be different for the changes observed (e.g. $\Phi_{\text {bwc }}$ can be 1.05 for change in protein concentration and 0.98 for change in phosphorus concentration).

Table 37: Adaptation of equations for broilers (change in body weight gain composition)

\begin{tabular}{|c|c|}
\hline & Basis for calculation \\
\hline Equation FA-2 & $\mathrm{P}_{\text {retention }}\left(\Phi_{\mathrm{bwc}}\right)(\mathrm{kg})=\mathrm{TWG} \times \% \mathrm{P}$ in tissues and bone $\times \Phi_{\mathrm{bwc}} / 100$ \\
\hline Equation FA-4 & $\mathrm{Cu}_{\text {retention }}\left(\Phi_{\mathrm{bwc}}\right)(\mathrm{kg})=\mathrm{TWG} \times \% \mathrm{Cu}$ in tissues and bone $\times \Phi_{\mathrm{bwc}} / 100$ \\
\hline \multirow[t]{3}{*}{ Equation FA-6 } & $\mathrm{Zn}_{\text {retention }}\left(\Phi_{\mathrm{bwc}}\right)(\mathrm{kg})=\mathrm{TWG} \times \% \mathrm{Zn}$ in tissues and bone $\times \Phi_{\mathrm{bwc}} / 100$ \\
\hline & Calculated impacts \\
\hline & Total \\
\hline Equation PO-8 & $\mathrm{N}_{\text {excreted }}\left(\Phi_{\mathrm{bwc}}\right)(\mathrm{kg})=\Sigma\left(\mathrm{FI}_{\mathrm{Ph}} \times \% \mathrm{CP}_{\mathrm{Ph}} / 100\right) / 6.25 \times\left(1-0.602 \times \Phi_{\mathrm{bwc}}\right)$ \\
\hline Equation FA-9 & $\mathrm{P}_{\text {excreted }}\left(\Phi_{\text {bwc }}\right)(\mathrm{kg})=\mathrm{P}_{\text {intake }}-\mathrm{P}_{\text {retention }}\left(\Phi_{\text {bwc }}\right)$ \\
\hline Equation FA-10 & $\mathrm{Cu}_{\text {excreted }}\left(\Phi_{\mathrm{bwc}}\right)(\mathrm{kg})=\mathrm{Cu}_{\text {intake }}-\mathrm{Cu}_{\text {retention }}\left(\Phi_{\mathrm{bwc}}\right)$ \\
\hline Equation FA-11 & $\mathrm{Zn}_{\text {excreted }}\left(\Phi_{\mathrm{bwc}}\right)(\mathrm{kg})=\mathrm{Zn}_{\text {intake }}-\mathrm{Zn}_{\text {retention }}\left(\Phi_{\mathrm{bwc}}\right)$ \\
\hline \multirow[t]{2}{*}{ Equation PO-13 } & $\mathrm{N}_{2} \mathrm{O}_{\text {manure }}\left(\Phi_{\mathrm{bwc}}\right)(\mathrm{kg})=\mathrm{N}_{\text {excreted }}\left(\Phi_{\mathrm{bwc}}\right) \times \mathrm{EF}_{\mathrm{MMS}} \times 44 / 28$ \\
\hline & Intensity \\
\hline Equation PO-14 & $\mathrm{N}_{\text {excreted }}$ Intensity $\left(\Phi_{\text {bwc }}\right)(\mathrm{kg} / \mathrm{kg}$ live weight $)=\mathrm{N}_{\text {excreted }}\left(\Phi_{\text {bwc }}\right) / \mathrm{TWG}$ \\
\hline Equation FA-15 & $\mathrm{P}_{\text {excreted }}$ Intensity $\left(\Phi_{\mathrm{bwc}}\right)(\mathrm{kg} / \mathrm{kg}$ live weight $)=\mathrm{P}_{\text {excreted }}\left(\Phi_{\mathrm{bwc}}\right) / \mathrm{TWG}$ \\
\hline Equation FA-16 & $\mathrm{Cu}_{\text {excreted }}$ Intensity $\left(\Phi_{\text {bwc }}\right)(\mathrm{kg} / \mathrm{kg}$ live weight $)=\mathrm{Cu}_{\text {excreted }}\left(\Phi_{\text {bwc }}\right) / \mathrm{TWG}$ \\
\hline Equation FA-17 & $\mathrm{Zn}_{\text {excreted }}$ Intensity $\left(\Phi_{\mathrm{bwc}}\right)(\mathrm{kg} / \mathrm{kg}$ live weight $)=\mathrm{Zn}_{\text {excreted }}\left(\Phi_{\mathrm{bwc}}\right) / \mathrm{TWG}$ \\
\hline Equation PO-19 & $\mathrm{N}_{2} \mathrm{O}_{\text {manure }}$ Intensity $\left(\Phi_{\mathrm{bwc}}\right)(\mathrm{kg} / \mathrm{kg}$ live weight $)=\mathrm{N}_{2} \mathrm{O}_{\text {manure }}\left(\Phi_{\mathrm{bwc}}\right) / \mathrm{TWG}$ \\
\hline
\end{tabular}

Note: $\Phi_{\text {bwc }}=$ change in body weight gain composition.

When the feed additive or the combination has a direct effect on methane $\left(\mathrm{CH}_{4}\right)$ or nitrous oxide $\left(\mathrm{N}_{2} \mathrm{O}\right)$ emissions, the factor $\Phi_{\mathrm{ef}}$ is used for the modification of the emission factor in the relevant equations. Although the factor is named in the same way in the equations $\left(\Phi_{\mathrm{ef}}\right)$, it will differ for the relevant emissions. 
Table 38: Adaptation of equations for broilers (change in emission factor)

\begin{tabular}{lc} 
& Calculated impacts \\
\hline Equation PO-12 & $\mathrm{CH}_{4 \text { manure }}\left(\Phi_{\mathrm{ef}}\right)(\mathrm{kg})=\mathrm{VS} \times \mathrm{Bo} \times \mathrm{MCF} \times \Phi_{\mathrm{ef}} \times 0.662$ \\
\hline Equation PO-13 & $\mathrm{N}_{2} \mathrm{O}_{\text {manure }}\left(\Phi_{\mathrm{ef}}\right)(\mathrm{kg})=\mathrm{N}_{\text {excreted }} \times \mathrm{EF}_{\mathrm{MMS}} \times \Phi_{\mathrm{ef}} \times 44 / 28$ \\
\hline & Intensity \\
\hline Equation PO-18 & $\mathrm{CH}_{\text {4manure }}$ Intensity $\left(\Phi_{\mathrm{ef}}\right)(\mathrm{kg} / \mathrm{kg}$ live weight $)=\mathrm{CH}_{4 \text { manure }}\left(\Phi_{\mathrm{ef}}\right) / \mathrm{TWG}$ \\
\hline Equation PO-19 & $\mathrm{N}_{2} \mathrm{O}_{\text {manure }}$ Intensity $\left(\Phi_{\mathrm{ef}}\right)(\mathrm{kg} / \mathrm{kg}$ live weight $)=\mathrm{N}_{2} \mathrm{O}_{\text {manure }}\left(\Phi_{\mathrm{ef}}\right) / \mathrm{TWG}$ \\
\hline Note: $\Phi_{\mathrm{ef}}=$ change in emission factor. &
\end{tabular}

\section{vii. Poultry (turkeys) \\ Baseline scenario}

Table 39 lists the equations relevant for the evaluation of the environmental impact of turkeys for the baseline scenario. The equations originating from the LEAP poultry guidelines (FAO, 2016d) are noted "Equation PO-n". For consistency with the other species and while the detailed equations are not available in the poultry guidelines, additional equations have been included, noted "Equation FA-n". The calculated impacts will be the comparison point for the feed additive scenario. Definitions of parameters and variables used in the equations are given in Table 2.

Turkey production comprises different phases (starter, finisher). The consideration of the different phase is noted as $\mathrm{Ph}$. When calculating the impact, the sum of the impacts during the different phases should be calculated.

Table 39: Equations used for evaluating the baseline emissions for turkeys

\begin{tabular}{|c|c|}
\hline & Basis for calculation \\
\hline Equation FA-1 & $P_{\text {intake }}(\mathrm{kg})=\Sigma\left(\mathrm{FI}_{\mathrm{Ph}} \times \% \mathrm{P}_{\text {totalPh }}\right) / 100$ \\
\hline Equation FA-2 & $\mathrm{P}_{\text {retention }}(\mathrm{kg})=\mathrm{TWG} \times \% \mathrm{P}$ in tissues and bones $/ 100$ \\
\hline Equation FA-3 & $\mathrm{Cu}_{\text {intake }}(\mathrm{kg})=\Sigma\left(\mathrm{FI}_{\mathrm{Ph}} \times \% \mathrm{Cu}_{\mathrm{Ph}}\right) / 100$ \\
\hline Equation FA-4 & $\mathrm{Cu}_{\text {retention }}(\mathrm{kg})=\mathrm{TWG} \times \% \mathrm{Cu}$ in tissues and bones $/ 100$ \\
\hline Equation FA-5 & $\mathrm{Zn}_{\text {intake }}(\mathrm{kg})=\Sigma\left(\mathrm{FI}_{\mathrm{Ph}} \times \% \mathrm{Zn}_{\mathrm{Ph}}\right) / 100$ \\
\hline Equation $\mathrm{PO}-6$ & $\mathrm{Zn}_{\text {retention }}(\mathrm{kg})=\mathrm{TWG} \times \% \mathrm{Zn}$ in tissues and bones $/ 100$ \\
\hline \multirow[t]{3}{*}{ Equation PO-7 } & $\mathrm{VS}(\mathrm{kg})=\Sigma\left(\mathrm{FI}_{\mathrm{Ph}} \times(1-\mathrm{DMD}) \times(1-\mathrm{A})\right)$ \\
\hline & Calculated impacts \\
\hline & Total \\
\hline Equation PO-8 & $\mathrm{N}_{\text {excreted }}(\mathrm{kg})=\Sigma\left(\mathrm{FI}_{\mathrm{Ph}} \times \% \mathrm{CP}_{\mathrm{Ph}} / 100\right) / 6.25 \times(1-0.588)$ \\
\hline Equation FA-9 & $\mathrm{P}_{\text {excreted }}(\mathrm{kg})=\mathrm{P}_{\text {intake }}-\mathrm{P}_{\text {retention }}$ \\
\hline Equation FA-10 & $\mathrm{Cu}_{\text {excreted }}(\mathrm{kg})=\mathrm{Cu}_{\text {intake }}-\mathrm{Cu}_{\text {retention }}$ \\
\hline Equation FA-11 & $\mathrm{Zn}_{\text {excreted }}(\mathrm{kg})=\mathrm{Zn}_{\text {intake }}-\mathrm{Zn}_{\text {retention }}$ \\
\hline Equation PO-12 & $\mathrm{CH}_{4 \text { manure }}(\mathrm{kg})=\mathrm{VS} \times \mathrm{Bo} \times \mathrm{MCF} \times 0.662$ \\
\hline \multirow[t]{2}{*}{ Equation PO-13 } & $\mathrm{N}_{2} \mathrm{O}_{\text {manure }}(\mathrm{kg})=\mathrm{N}_{\text {excreted }} \times \mathrm{EF}_{\mathrm{MMS}} \times 44 / 28$ \\
\hline & Intensity \\
\hline Equation PO-14 & $\mathrm{N}_{\text {excreted }}$ Intensity $(\mathrm{kg} / \mathrm{kg}$ live weight $)=\mathrm{N}_{\text {excreted }} / \mathrm{TWG}$ \\
\hline Equation FA-15 & $\mathrm{P}_{\text {excreted }}$ Intensity $(\mathrm{kg} / \mathrm{kg}$ live weight $)=\mathrm{P}_{\text {excreted }} / \mathrm{TWG}$ \\
\hline Equation FA-16 & $\mathrm{Cu}_{\text {excreted }}$ Intensity $(\mathrm{kg} / \mathrm{kg}$ live weight $)=\mathrm{Cu}_{\text {excreted }} / \mathrm{TWG}$ \\
\hline Equation FA-17 & $\mathrm{Zn}_{\text {excreted }}$ Intensity $(\mathrm{kg} / \mathrm{kg}$ live weight $)=\mathrm{Zn}_{\text {excreted }} / \mathrm{TWG}$ \\
\hline Equation PO-18 & $\mathrm{CH}_{4 \text { manure }}$ Intensity $(\mathrm{kg}$ kg live weight $)=\mathrm{CH}_{4 \text { manure }} / \mathrm{TWG}$ \\
\hline Equation PO-19 & $\mathrm{N}_{2} \mathrm{O}_{\text {manure }}$ Intensity $(\mathrm{kg} / \mathrm{kg}$ live weight $)=\mathrm{N}_{2} \mathrm{O}_{\text {manure }} / \mathrm{TWG}$ \\
\hline
\end{tabular}




\section{Feed additive scenarios}

Tables 40-44 provide the changes in the equations linked to the effect of the feed additives or combination of feed additives on the parameters. Each table provides information on the potential effects of the feed additives or the combinations of feed additives (subsection 6.10.3 [i-iii]), as follows:

- modification of feed composition (Table 40)

- feed efficiency (Tables 41, 42, 43)

- emission factors (Table 44)

When the change in the equations used as a basis for the calculation (upper part of the tables) modifies the calculated impact, the corresponding equations are also indicated (lower part of the tables). For example, when the concentration of nitrogen is changed in the diet (use of the factor $\Phi_{\text {nc }}$ ), the result of both the $\mathrm{N}_{\text {intake }}$ and the $\mathrm{N}_{\text {excreted }}$ is changed. Hence these equations are also indicated. It should be noted that the factor might be different for the changes observed (e.g. $\Phi_{\mathrm{nc}}$ can be 1.05 for change in protein concentration and 0.98 for change in phosphorus concentration).

Table 40: Adaptation of equations for turkeys (change in feed composition)

\begin{tabular}{|c|c|}
\hline & Basis for calculation \\
\hline Equation FA-1 & $\mathrm{P}_{\text {intake }}\left(\Phi_{\mathrm{nc}}\right)(\mathrm{kg})=\Sigma\left(\mathrm{FI}_{\mathrm{Ph}} \times \% \mathrm{P}_{\text {totalPh }} \times \Phi_{\mathrm{nc}}\right) / 100$ \\
\hline Equation FA-3 & $\mathrm{Cu}_{\text {intake }}\left(\Phi_{\mathrm{nc}}\right)(\mathrm{kg})=\Sigma\left(\mathrm{FI}_{\mathrm{Ph}} \times \% \mathrm{Cu}_{\mathrm{Ph}} \times \Phi_{\mathrm{nc}}\right) / 100$ \\
\hline \multirow{3}{*}{ Equation FA-5 } & $\mathrm{Zn}_{\text {intake }}\left(\Phi_{\mathrm{nc}}\right)(\mathrm{kg})=\Sigma\left(\mathrm{FI}_{\mathrm{Ph}} \times \% \mathrm{Zn}_{\mathrm{Ph}} \times \Phi_{\mathrm{nc}}\right) / 100$ \\
\hline & Calculated impacts \\
\hline & Total \\
\hline Equation PO-8 & $\mathrm{N}_{\text {excreted }}\left(\Phi_{\mathrm{nc}}\right)(\mathrm{kg})=\Sigma\left(\mathrm{FI}_{\mathrm{Ph}} \times \% \mathrm{CP}_{\mathrm{Ph}} \times \Phi_{\mathrm{nc}} / 100\right) / 6.25 \times(1-0.588)$ \\
\hline Equation FA-9 & $\mathrm{P}_{\text {excreted }}\left(\Phi_{\mathrm{nc}}\right)(\mathrm{kg})=\mathrm{P}_{\text {intake }}\left(\Phi_{\mathrm{nc}}\right)-\mathrm{P}_{\text {retention }}$ \\
\hline Equation FA-10 & $\mathrm{Cu}_{\text {excreted }}\left(\Phi_{\mathrm{nc}}\right)(\mathrm{kg})=\mathrm{Cu}_{\text {intake }}\left(\Phi_{\mathrm{nc}}\right)-\mathrm{Cu}_{\text {retention }}$ \\
\hline Equation FA-11 & $\mathrm{Zn}_{\text {excreted }}(\mathrm{kg})=\mathrm{Zn}_{\text {intake }}\left(\Phi_{\mathrm{nc}}\right)-\mathrm{Zn}_{\text {retention }}$ \\
\hline \multirow[t]{2}{*}{ Equation PO-13 } & $\mathrm{N}_{2} \mathrm{O}_{\text {manure }}\left(\Phi_{\mathrm{nc}}\right)(\mathrm{kg})=\mathrm{N}_{\text {excreted }}\left(\Phi_{\mathrm{nc}}\right) \times \mathrm{EF}_{\mathrm{MMS}} \times 44 / 28$ \\
\hline & Intensity \\
\hline Equation PO-14 & $\mathrm{N}_{\text {excreted }}$ Intensity $\left(\Phi_{\mathrm{nc}}\right)(\mathrm{kg} / \mathrm{kg}$ live weight $)=\mathrm{N}_{\text {excreted }}\left(\Phi_{\mathrm{nc}}\right) / \mathrm{TWG}$ \\
\hline Equation FA-15 & $\mathrm{P}_{\text {excreted }}$ Intensity $\left(\Phi_{\mathrm{nc}}\right)(\mathrm{kg} / \mathrm{kg}$ live weight $)=\mathrm{P}_{\text {excreted }}\left(\Phi_{\mathrm{nc}}\right) / \mathrm{TWG}$ \\
\hline Equation FA-16 & $\mathrm{Cu}_{\text {excreted }}$ Intensity $\left(\Phi_{\mathrm{nc}}\right)(\mathrm{kg} / \mathrm{kg}$ live weight $)=\mathrm{Cu}_{\text {excreted }}\left(\Phi_{\mathrm{nc}}\right) / \mathrm{TWG}$ \\
\hline Equation FA-17 & $\mathrm{Zn}_{\text {excreted }}$ Intensity $\left(\Phi_{\mathrm{nc}}\right)(\mathrm{kg} / \mathrm{kg}$ live weight $)=\mathrm{Zn}_{\text {excreted }}\left(\Phi_{\mathrm{nc}}\right) / \mathrm{TWG}$ \\
\hline Equation PO-19 & $\mathrm{N}_{2} \mathrm{O}_{\text {manure }}$ Intensity $\left(\Phi_{\mathrm{nc}}\right)(\mathrm{kg} / \mathrm{kg}$ live weight $)=\mathrm{N}_{2} \mathrm{O}_{\text {manure }}\left(\Phi_{\mathrm{nc}}\right) / \mathrm{TWG}$ \\
\hline
\end{tabular}

Note: $\Phi_{\mathrm{nc}}=$ change in feed composition (protein, phosphorus, copper and zinc content); subscript Ph means the growing phase (e.g. \% $\mathrm{Cu}_{\mathrm{Ph}}$ represents the copper content of the feed during a specific growing phase such as starter).

When a feed additive or combination of feed additives modifies the feed efficiency of turkeys, it could be through a modification of one or more of the following:

- feed intake $\left(\Phi_{\mathrm{fi}}\right)($ Table 41$)$

- weight gain $\left(\Phi_{\mathrm{wg}}\right)$ (Table 42$)$

- weight gain composition $\left(\Phi_{\mathrm{wgc}}\right)$ (Table 43 )

In the case that the feed additive or combination of feed additives has an impact on more than one of the above-mentioned parameters, it is advised to combine the different impacts accordingly. For example, if the feed additive or combination of feed additives modifies the feed intake $\left(\Phi_{\mathrm{f}}\right)$ and the weight gain $\left(\Phi_{\mathrm{wg}}\right)$, the phosphorus balance will be recalculated as follows: 
- $\mathrm{P}_{\text {intake }}\left(\Phi_{\mathrm{fi}}\right)(\mathrm{kg})=\Sigma\left(\mathrm{FI}_{\mathrm{Ph}} \times \Phi_{\mathrm{fi}} \times\left(\% \mathrm{P}_{\text {totalPh }} / 100\right)\right)($ Equation FA-1 adapted $)$

- $\mathrm{P}_{\text {retention }}\left(\Phi_{\mathrm{wg}}\right)(\mathrm{kg})=\left(\mathrm{TWG} \times \Phi_{\mathrm{wg}} \times \% \mathrm{P}\right.$ in tissues and bones/100) (Equation FA-2 adapted)

This will lead to a modification of the phosphorus excretion.

Table 41: Adaptation of equations for turkeys (change in feed intake)

\begin{tabular}{|c|c|}
\hline & Basis for calculation \\
\hline Equation FA-1 & $\mathrm{P}_{\text {intake }}\left(\Phi_{\mathrm{fi}}\right)(\mathrm{kg})=\Sigma\left(\mathrm{FI}_{\mathrm{Ph}} \times \Phi_{\mathrm{fi}} \times \% \mathrm{P}_{\text {totalPh }}\right) / 100$ \\
\hline Equation FA-3 & $\mathrm{Cu}_{\text {intake }}\left(\Phi_{\mathrm{fi}}\right)(\mathrm{kg})=\Sigma\left(\mathrm{FI}_{\mathrm{Ph}} \times \Phi_{\mathrm{fi}} \times \% \mathrm{Cu}_{\mathrm{Ph}}\right) / 100$ \\
\hline Equation FA-5 & $\mathrm{Zn}_{\text {intake }}\left(\Phi_{\mathrm{fi}}\right)(\mathrm{kg})=\Sigma\left(\mathrm{FI}_{\mathrm{Ph}} \times \Phi_{\mathrm{fi}} \times \% \mathrm{Zn}_{\mathrm{Ph}}\right) / 100$ \\
\hline \multirow[t]{3}{*}{ Equation PO-7 } & $\operatorname{VS}\left(\Phi_{\mathrm{fi}}\right)(\mathrm{kg})=\Sigma\left(\mathrm{FI}_{\mathrm{Ph}} \times \Phi_{\mathrm{fi}} \times(1-\mathrm{DMD}) \times(1-\mathrm{A})\right)$ \\
\hline & Calculated impacts \\
\hline & Total \\
\hline Equation $\mathrm{PO}-8$ & $\mathrm{~N}_{\text {excreted }}\left(\Phi_{\mathrm{fi}}\right)(\mathrm{kg})=\Sigma\left(\mathrm{FI}_{\mathrm{Ph}} \times \Phi_{\mathrm{fi}} \times \% \mathrm{CP}_{\mathrm{Ph}} / 100\right) / 6.25 \times(1-0.588)$ \\
\hline Equation FA-9 & $\mathrm{P}_{\text {excreted }}\left(\Phi_{\mathrm{fi}}\right)(\mathrm{kg})=\mathrm{P}_{\text {intake }}\left(\Phi_{\mathrm{fi}}\right)-\mathrm{P}_{\text {retention }}$ \\
\hline Equation FA-10 & $\mathrm{Cu}_{\text {excreted }}\left(\Phi_{\mathrm{fi}}\right)(\mathrm{kg})=\mathrm{Cu}_{\text {intake }}\left(\Phi_{\mathrm{fi}}\right)-\mathrm{Cu}_{\text {retention }}$ \\
\hline Equation FA-11 & $\mathrm{Zn}_{\text {excreted }}\left(\Phi_{\mathrm{fi}}\right)(\mathrm{kg})=\mathrm{Zn}_{\text {intake }}\left(\Phi_{\mathrm{fi}}\right)-\mathrm{Zn}_{\text {retention }}$ \\
\hline Equation PO-12 & $\mathrm{CH}_{4 \text { manure }}\left(\Phi_{\mathrm{fi}}\right)(\mathrm{kg})=\mathrm{VS}\left(\Phi_{\mathrm{fi}}\right) \times \mathrm{Bo} \times \mathrm{MCF} \times 0.662$ \\
\hline \multirow[t]{2}{*}{ Equation PO-13 } & $\mathrm{N}_{2} \mathrm{O}_{\text {manure }}\left(\Phi_{\mathrm{fi}}\right)(\mathrm{kg})=\mathrm{N}_{\text {excreted }}\left(\Phi_{\mathrm{fi}}\right) \times \mathrm{EF}_{\text {MMS }} \times 44 / 28$ \\
\hline & Intensity \\
\hline Equation PO-14 & $\mathrm{N}_{\text {excreted }}$ Intensity $\left(\Phi_{\mathrm{fi}}\right)(\mathrm{kg} / \mathrm{kg}$ live weight $)=\mathrm{N}_{\text {excreted }}\left(\Phi_{\mathrm{fi}}\right) / \mathrm{TWG}$ \\
\hline Equation FA-15 & $\mathrm{P}_{\text {excreted }}$ Intensity $\left(\Phi_{\mathrm{fi}}\right)(\mathrm{kg} / \mathrm{kg}$ live weight $)=\mathrm{P}_{\text {excreted }}\left(\Phi_{\mathrm{f}}\right) / \mathrm{TWG}$ \\
\hline Equation FA-16 & $\mathrm{Cu}_{\text {excreted }}$ Intensity $\left(\Phi_{\mathrm{fi}}\right)(\mathrm{kg} / \mathrm{kg}$ live weight $)=\mathrm{Cu}_{\text {excreted }}\left(\Phi_{\mathrm{fi}}\right) / \mathrm{TWG}$ \\
\hline Equation FA-17 & $\mathrm{Zn}_{\text {excreted }}$ Intensity $\left(\Phi_{\mathrm{fi}}\right)(\mathrm{kg} / \mathrm{kg}$ live weight $)=\mathrm{Zn}_{\text {excreted }}\left(\Phi_{\mathrm{f}}\right) / \mathrm{TWG}$ \\
\hline Equation PO-18 & $\mathrm{CH}_{4 \text { manure }}$ Intensity $\left(\Phi_{\mathrm{fi}}\right)(\mathrm{kg} / \mathrm{kg}$ live weight $)=\mathrm{CH}_{4 \text { manure }}\left(\Phi_{\mathrm{fi}}\right) / \mathrm{TWG}$ \\
\hline Equation PO-19 & $\mathrm{N}_{2} \mathrm{O}_{\text {manure }}$ Intensity $\left(\Phi_{\mathrm{fi}}\right)(\mathrm{kg} / \mathrm{kg}$ live weight $)=\mathrm{N}_{2} \mathrm{O}_{\text {manure }}\left(\Phi_{\mathrm{f}}\right) / \mathrm{TWG}$ \\
\hline
\end{tabular}

Note: $\Phi_{\mathrm{fi}}=$ change in feed intake; subscript Ph means the growing phase (e.g. \% Cuph represents the copper content of the feed during a specific growing phase such as starter).

In the case of a modification of the animal performance, the total weight gain is modified as follows:

$\operatorname{TWG}\left(\Phi_{\mathrm{gp}}\right)=\mathrm{TWG} \times \Phi_{\mathrm{gp}}$

Hence the emission intensity is modified.

Table 42: Adaptation of equations for turkeys (change in growth performance)

\begin{tabular}{lc} 
Equation FA-2 & $\mathrm{P}_{\text {retention }}\left(\Phi_{\mathrm{gp}}\right)(\mathrm{kg})=\mathrm{TWG} \times \Phi_{\mathrm{gp}} \times \% \mathrm{P}$ in tissues and bones $/ 100$ \\
\hline Equation FA-4 & $\mathrm{Cu}_{\text {retention }}\left(\Phi_{\mathrm{gp}}\right)(\mathrm{kg})=\mathrm{TWG} \times \Phi_{\mathrm{gp}} \times \% \mathrm{Cu}$ in tissues and bones $/ 100$ \\
\hline Equation PO-6 & $\mathrm{Zn}_{\text {retention }}\left(\Phi_{\mathrm{gp}}\right)(\mathrm{kg})=\mathrm{TWG} \times \Phi_{\mathrm{gp}} \times \% \mathrm{Zn}$ in tissues and bones $/ 100$ \\
& Calculated impacts \\
\hline Equation PO-8 & Total \\
\hline Equation FA-9 & $\mathrm{N}_{\text {excreted }}\left(\Phi_{\mathrm{gp}}\right)(\mathrm{kg})=\Sigma\left(\mathrm{FI}_{\mathrm{Ph}} \times \% \mathrm{CP}_{\mathrm{Ph}} / 100\right) / 6.25 \times\left(1-0.588 \times \Phi_{\mathrm{gp}}\right)$ \\
\hline Equation FA-10 & $\mathrm{P}_{\text {excreted }}\left(\Phi_{\mathrm{gp}}\right)(\mathrm{kg})=\mathrm{P}_{\text {intake }}-\mathrm{P}_{\text {retention }}\left(\Phi_{\mathrm{gp}}\right)$ \\
\hline Equation FA-11 & $\mathrm{Cu}_{\text {excreted }}\left(\Phi_{\mathrm{gp}}\right)(\mathrm{kg})=\mathrm{Cu}_{\text {intake }}-\mathrm{Cu}_{\text {retention }}\left(\Phi_{\mathrm{gp}}\right)$ \\
\hline
\end{tabular}


Environmental performance of feed additives in livestock supply

\begin{tabular}{lc}
\hline & Intensity \\
\hline Equation PO-14 & $\mathrm{N}_{\text {excreded }}$ Intensity $\left(\Phi_{\mathrm{gp}}\right)(\mathrm{kg} / \mathrm{kg}$ live weight $)=\mathrm{N}_{\text {excreted }}\left(\Phi_{\mathrm{gp}}\right) / \mathrm{TWG}\left(\Phi_{\mathrm{gp}}\right)$ \\
\hline Equation FA-15 & $\mathrm{P}_{\text {excreted }}$ Intensity $\left(\Phi_{\mathrm{gp}}\right)(\mathrm{kg} / \mathrm{kg}$ live weight $)=\mathrm{P}_{\text {excreted }}\left(\Phi_{\mathrm{gp}}\right) / \mathrm{TWG}\left(\Phi_{\mathrm{gp}}\right)$ \\
\hline Equation FA-16 & $\mathrm{Cu}_{\text {excreed }}$ Intensity $\left(\Phi_{\mathrm{gp}}\right)(\mathrm{kg} / \mathrm{kg}$ live weight $)=\mathrm{Cu}_{\text {excreted }}\left(\Phi_{\mathrm{gp}}\right) / \mathrm{TWG}\left(\Phi_{\mathrm{gp}}\right)$ \\
\hline Equation FA-17 & $\mathrm{Zn}_{\text {excreted }}$ Intensity $\left(\Phi_{\mathrm{gp}}\right)(\mathrm{kg} / \mathrm{kg}$ live weight $)=\mathrm{Zn}_{\text {excreted }}\left(\Phi_{\mathrm{gp}}\right) / \mathrm{TWG}\left(\Phi_{\mathrm{gp}}\right)$ \\
\hline Equation PO-18 & $\mathrm{CH}_{4 \text { manure }}$ Intensity $\left(\Phi_{\mathrm{gp}}\right)(\mathrm{kg} / \mathrm{kg}$ live weight $)=\mathrm{CH}_{4 \text { manure }} / \mathrm{TWG}\left(\Phi_{\mathrm{gp}}\right)$ \\
\hline Equation PO-19 & $\mathrm{N}_{2} \mathrm{O}_{\text {manure }}$ Intensity $\left(\Phi_{\mathrm{gp}}\right)(\mathrm{kg} / \mathrm{kg}$ live weight $)=\mathrm{N}_{2} \mathrm{O}_{\text {manure }}\left(\Phi_{\mathrm{gp}}\right) / \mathrm{TWG}\left(\Phi_{\mathrm{gp}}\right)$ \\
\hline Note: $\Phi_{\mathrm{gp}}=$ change in growth performance.
\end{tabular}

When the feed additive or combination of feed additives modifies the body weight gain composition, the factor $\Phi_{\text {bwc }}$ is used in the equations (Table 43). It should be noted that the factor might be different for the changes observed (e.g. $\Phi_{\text {bwc }}$ can be 1.05 for change in protein concentration and 0.98 for change in phosphorus concentration).

Table 43: Adaptation of equations for turkeys (change in body weight gain composition)

\begin{tabular}{|c|c|}
\hline & Basis for calculation \\
\hline Equation FA-2 & $\mathrm{P}_{\text {retention }}\left(\Phi_{\mathrm{bwc}}\right)(\mathrm{kg})=\mathrm{TWG} \times \% \mathrm{P}$ in tissues and bones $\times \Phi_{\mathrm{bwc}} / 100$ \\
\hline Equation FA-4 & $\mathrm{Cu}_{\text {retention }}\left(\Phi_{\mathrm{bwc}}\right)(\mathrm{kg})=\mathrm{TWG} \times \% \mathrm{Cu}$ in tissues and bone $\times \Phi_{\mathrm{bwc}} / 100$ \\
\hline \multirow[t]{3}{*}{ Equation PO-6 } & $\mathrm{Zn}_{\text {retention }}\left(\Phi_{\mathrm{bwc}}\right)(\mathrm{kg})=\mathrm{TWG} \times \% \mathrm{Zn}$ in tissues and bone $\times \Phi_{\mathrm{bwc}} / 100$ \\
\hline & Calculated impacts \\
\hline & Total \\
\hline Equation PO-8 & $\mathrm{N}_{\text {excreted }}\left(\Phi_{\mathrm{bwc}}\right)(\mathrm{kg})=\Sigma\left(\mathrm{FI}_{\mathrm{Ph}} \times \% \mathrm{CP}_{\mathrm{Ph}} / 100\right) / 6.25 \times\left(1-0.588 \times \Phi_{\mathrm{bwc}}\right)$ \\
\hline Equation FA-9 & $\mathrm{P}_{\text {excreted }}\left(\Phi_{\text {bwc }}\right)(\mathrm{kg})=\mathrm{P}_{\text {intake }}-\mathrm{P}_{\text {retention }}\left(\Phi_{\mathrm{bwc}}\right)$ \\
\hline Equation FA-10 & $\mathrm{Cu}_{\text {excreted }}\left(\Phi_{\text {bwc }}\right)(\mathrm{kg})=\mathrm{Cu}_{\text {intake }}-\mathrm{Cu}_{\text {retention }}\left(\Phi_{\text {bwc }}\right)$ \\
\hline Equation FA-11 & $\mathrm{Zn}_{\text {excreted }}\left(\Phi_{\text {bwc }}\right)(\mathrm{kg})=\mathrm{Zn}_{\text {intake }}-\mathrm{Zn}_{\text {retention }}\left(\Phi_{\text {bwc }}\right)$ \\
\hline \multirow[t]{2}{*}{ Equation PO-13 } & $\mathrm{N}_{2} \mathrm{O}_{\text {manure }}\left(\Phi_{\text {bwc }}\right)(\mathrm{kg})=\mathrm{N}_{\text {excreted }}\left(\Phi_{\text {bwc }}\right) \times \mathrm{EF}_{\mathrm{MMS}} \times 44 / 28$ \\
\hline & Intensity \\
\hline Equation PO-14 & $\mathrm{N}_{\text {excreted }}$ Intensity $\left(\Phi_{\mathrm{bwc}}\right)(\mathrm{kg} / \mathrm{kg}$ live weight $)=\mathrm{N}_{\text {excreted }}\left(\Phi_{\mathrm{bwc}}\right) / \mathrm{TWG}$ \\
\hline Equation FA-15 & $\mathrm{P}_{\text {excreted }}$ Intensity $\left(\Phi_{\mathrm{bwc}}\right)(\mathrm{kg} / \mathrm{kg}$ live weight $)=\mathrm{P}_{\text {excreted }}\left(\Phi_{\mathrm{bwc}}\right) / \mathrm{TWG}$ \\
\hline Equation FA-16 & $\mathrm{Cu}_{\text {excreted }}$ Intensity $\left(\Phi_{\mathrm{bwc}}\right)(\mathrm{kg} / \mathrm{kg}$ live weight $)=\mathrm{Cu}_{\text {excreted }}\left(\Phi_{\mathrm{bwc}}\right) / \mathrm{TWG}$ \\
\hline Equation FA-17 & $\mathrm{Zn}_{\text {excreted }}$ Intensity $\left(\Phi_{\mathrm{bwc}}\right)(\mathrm{kg} / \mathrm{kg}$ live weight $)=\mathrm{Zn}_{\text {excreted }}\left(\Phi_{\mathrm{bwc}}\right) / \mathrm{TWG}$ \\
\hline Equation PO-19 & $\mathrm{N}_{2} \mathrm{O}_{\text {manure }}$ Intensity $\left(\Phi_{\text {bwc }}\right)(\mathrm{kg} / \mathrm{kg}$ live weight $)=\mathrm{N}_{2} \mathrm{O}_{\text {manure }}\left(\Phi_{\text {bwc }}\right) / \mathrm{TWG}$ \\
\hline
\end{tabular}

Note: $\Phi_{\text {bwc }}=$ change in body weight gain composition.

When the feed additive or combination of feed additives has a direct effect on methane $\left(\mathrm{CH}_{4}\right)$ or nitrous oxide $\left(\mathrm{N}_{2} \mathrm{O}\right)$ emissions, the factor $\Phi_{\text {ef }}$ is used for the modification of the emission factor in the relevant equations. Although the factor is named in the same way in the equations $\left(\Phi_{\mathrm{ef}}\right)$, it will differ for the relevant emissions. 
Table 44: Adaptation of equations for turkeys (change in emission factor)

\begin{tabular}{lc} 
& Calculated impacts \\
\hline Equation PO-12 & $\mathrm{CH}_{4 \text { manure }}\left(\Phi_{\mathrm{ef}}\right)(\mathrm{kg})=\mathrm{VS} \times \mathrm{Bo} \times \mathrm{MCF} \times \Phi_{\mathrm{ef}} \times 0.662$ \\
\hline Equation PO-13 & $\mathrm{N}_{2} \mathrm{O}_{\text {manure }}\left(\Phi_{\mathrm{ef}}\right)(\mathrm{kg})=\mathrm{N}_{\text {excreted }} \times \mathrm{EF}_{\mathrm{MMS}} \times \Phi_{\mathrm{ef}} \times 44 / 28$ \\
\hline & Intensity \\
\hline Equation PO-18 & $\mathrm{CH}_{\text {4manure }}$ Intensity $\left(\Phi_{\mathrm{ef}}\right)(\mathrm{kg} / \mathrm{kg}$ live weight $)=\mathrm{CH}_{4 \text { manure }}\left(\Phi_{\mathrm{ef}}\right) / \mathrm{TWG}$ \\
\hline Equation PO-19 & $\mathrm{N}_{2} \mathrm{O}_{\text {manure }}$ Intensity $\left(\Phi_{\mathrm{ef}}\right)(\mathrm{kg} / \mathrm{kg}$ live weight $)=\mathrm{N}_{2} \mathrm{O}_{\text {manure }}\left(\Phi_{\mathrm{ef}}\right) / \mathrm{TWG}$ \\
\hline Note: $\Phi_{\mathrm{ef}}=$ change in emission factor.
\end{tabular}

\section{viii. Poultry (laying birds) \\ Baseline scenario}

Table 45 lists the equations relevant to the evaluation of the environmental impact of laying birds for the baseline scenario. The equations originating from the LEAP poultry guidelines (FAO, 2016d) are noted "Equation PO-n". For consistency with the other species and while the detailed equations are not available in the poultry guidelines, additional equations are included, noted "Equation FA-n". The calculated impacts will be the comparison point for the feed additive scenario. Definitions of parameters and variables used in the equations are given in Table 2.

The production of laying birds comprises different phases (start of lay, end of lay). The consideration of the different phase is noted as $\mathrm{Ph}$. When calculating the impact, the sum of the impacts during the different phases should be calculated.

Table 45: Equations used for evaluating the baseline emissions for laying birds

\begin{tabular}{|c|c|}
\hline & Basis for calculation \\
\hline Equation FA-1 & $\mathrm{P}_{\text {intake }}(\mathrm{kg})=\Sigma\left(\mathrm{FI}_{\mathrm{Ph}} \times \% \mathrm{P}_{\text {totalPh }}\right) / 100$ \\
\hline Equation FA-2 & $\mathrm{P}_{\text {retention }}(\mathrm{kg})=\mathrm{EW} \times \mathrm{ENb} \times \% \mathrm{P}$ eggs $/ 100$ \\
\hline Equation FA-3 & $\mathrm{Cu}_{\text {intake }}(\mathrm{kg})=\Sigma\left(\mathrm{FI}_{\mathrm{Ph}} \times \% \mathrm{Cu}_{\mathrm{Ph}}\right) / 100$ \\
\hline Equation FA-4 & $\mathrm{Cu}_{\text {retention }}(\mathrm{kg})=\mathrm{EW} \times \mathrm{ENb} \times \% \mathrm{Cu} / 100$ \\
\hline Equation FA-5 & $\mathrm{Zn}_{\text {intake }}(\mathrm{kg})=\Sigma\left(\mathrm{FI}_{\mathrm{Ph}} \times \% \mathrm{Zn}_{\mathrm{Ph}}\right) / 100$ \\
\hline Equation FA-6 & $\mathrm{Zn}_{\text {retention }}(\mathrm{kg})=\mathrm{EW} \times \mathrm{ENb} \times \% \mathrm{Zn}$ eggs $/ 100$ \\
\hline \multirow[t]{3}{*}{ Equation PO-7 } & $\mathrm{VS}(\mathrm{kg})=\Sigma\left(\mathrm{FI}_{\mathrm{Ph}} \times(1-\mathrm{DMD}) \times(1-\mathrm{A})\right)$ \\
\hline & Calculated impacts \\
\hline & Total \\
\hline Equation PO-8 & $\mathrm{N}_{\text {excreted }}(\mathrm{kg})=\Sigma\left(\mathrm{FI}_{\mathrm{Ph}} \times \% \mathrm{CP}_{\mathrm{Ph}} / 100\right) / 6.25 \times((0.0182 \times \mathrm{EW}) \times \mathrm{ENb})$ \\
\hline Equation FA-9 & $\mathrm{P}_{\text {excreted }}(\mathrm{kg})=\mathrm{P}_{\text {intake }}-\mathrm{P}_{\text {retained }}$ \\
\hline Equation FA-10 & $\mathrm{Cu}_{\text {excreted }}(\mathrm{kg})=\mathrm{Cu}_{\text {intake }}-\mathrm{Cu}_{\text {retained }}$ \\
\hline Equation FA-11 & $\mathrm{Zn}_{\text {excreted }}(\mathrm{kg})=\mathrm{Zn}_{\text {intake }}-\mathrm{Zn}_{\text {retained }}$ \\
\hline Equation PO-12 & $\mathrm{CH}_{4 \text { manure }}(\mathrm{kg})=\mathrm{VS} \times \mathrm{Bo} \times \mathrm{MCF} \times 0.662$ \\
\hline \multirow[t]{2}{*}{ Equation PO-13 } & $\mathrm{N}_{2} \mathrm{O}_{\text {manure }}(\mathrm{kg})=\mathrm{N}_{\text {excreted }} \times \mathrm{EF}_{\mathrm{MMS}} \times 44 / 28$ \\
\hline & Intensity \\
\hline Equation PO-14 & $\mathrm{N}_{\text {excreted }}$ Intensity $(\mathrm{kg} / \mathrm{kg}$ eggs in shell $)=\mathrm{N}_{\text {excreted }} / \mathrm{kg}$ eggs in shell \\
\hline Equation FA-15 & $\mathrm{P}_{\text {excreted }}$ Intensity $(\mathrm{kg} / \mathrm{kg}$ eggs in shell $)=\mathrm{P}_{\text {excreted }} / \mathrm{kg}$ eggs in shell \\
\hline Equation FA-16 & $\mathrm{Cu}_{\text {excreted }}$ Intensity $(\mathrm{kg} / \mathrm{kg}$ eggs in shell $)=\mathrm{Cu}_{\text {excreted }} / \mathrm{kg}$ eggs in shell \\
\hline Equation FA-17 & $\mathrm{Zn}_{\text {excreted }}$ Intensity $(\mathrm{kg} / \mathrm{kg}$ eggs in shell $)=\mathrm{Zn}_{\text {excreted }} / \mathrm{kg}$ eggs in shell \\
\hline Equation PO-18 & $\mathrm{CH}_{4 \text { manure }}$ Intensity $(\mathrm{kg} / \mathrm{kg}$ eggs in shell $)=\mathrm{CH}_{4 \text { manure }} / \mathrm{kg}$ eggs in shell \\
\hline Equation PO-19 & $\mathrm{N}_{2} \mathrm{O}_{\text {manure }}$ Intensity $(\mathrm{kg} / \mathrm{kg}$ eggs in shell $)=\mathrm{N}_{2} \mathrm{O}_{\text {manure }} / \mathrm{kg}$ eggs in shell \\
\hline
\end{tabular}




\section{Feed additive scenarios}

Tables 46-50 provide the changes in the equations linked to the effect of the feed additives or combination of feed additives on the parameters. Each table provides information on the potential effects of the feed additives or the combinations of feed additives (subsection 6.10.3 [i-iii]) as follows:

- modification of feed composition (Table 46)

- feed efficiency (Tables 47, 48, 49)

- emission factors (Table 50)

When the change in the equations used as a basis for the calculation (upper part of the tables) modifies the calculated impact, the corresponding equations are also indicated (lower part of the tables). As an example, when the concentration of nitrogen is changed in the diet (use of the factor $\Phi_{n c}$ ), the result of both the $\mathrm{N}_{\text {intake }}$ and the $\mathrm{N}_{\text {excreted }}$ is changed. Hence these equations are also indicated. It should be noted that the factor might be different for the changes observed (e.g. $\Phi_{\mathrm{nc}}$ can be 1.05 for change in protein concentration and 0.98 for change in phosphorus concentration).

Table 46: Adaptation of equations for laying birds (change in feed composition)

\begin{tabular}{|c|c|}
\hline & Basis for calculation \\
\hline Equation FA-1 & $\mathrm{P}_{\text {intake }}\left(\Phi_{\mathrm{nc}}\right)(\mathrm{kg})=\Sigma\left(\mathrm{FI}_{\mathrm{Ph}} \times \% \mathrm{P}_{\text {totalPh }} \times \Phi_{\mathrm{nc}}\right) / 100$ \\
\hline Equation FA-3 & $\mathrm{Cu}_{\text {intake }}\left(\Phi_{\mathrm{nc}}\right)(\mathrm{kg})=\Sigma\left(\mathrm{FI}_{\mathrm{Ph}} \times \% \mathrm{Cu}_{\mathrm{Ph}} \times \Phi_{\mathrm{nc}}\right) / 100$ \\
\hline \multirow[t]{3}{*}{ Equation FA-5 } & $\mathrm{Zn}_{\text {intake }}\left(\Phi_{\text {nc }}\right)(\mathrm{kg})=\Sigma\left(\mathrm{FI}_{\mathrm{Ph}} \times \% \mathrm{Zn}_{\mathrm{Ph}} \times \Phi_{\mathrm{nc}}\right) / 100$ \\
\hline & Calculated impacts \\
\hline & Total \\
\hline Equation PO-8 & $\mathrm{N}_{\text {excreted }}\left(\Phi_{\mathrm{nc}}\right)(\mathrm{kg})=\Sigma\left(\mathrm{FI}_{\mathrm{Ph}} \times \% \mathrm{CP}_{\mathrm{Ph}} \times \Phi_{\mathrm{nc}} / 100\right) / 6.25 \times((0.0182 \times \mathrm{EW}) \times \mathrm{ENb})$ \\
\hline Equation FA-9 & $\mathrm{P}_{\text {excreted }}\left(\Phi_{\mathrm{nc}}\right)(\mathrm{kg})=\mathrm{P}_{\text {intake }}\left(\Phi_{\mathrm{nc}}\right)-\mathrm{P}_{\text {retained }}$ \\
\hline Equation FA-10 & $\mathrm{Cu}_{\text {excreted }}\left(\Phi_{\mathrm{nc}}\right)(\mathrm{kg})=\mathrm{Cu}_{\text {intake }}\left(\Phi_{\mathrm{nc}}\right)-\mathrm{Cu}_{\text {retained }}$ \\
\hline Equation FA-11 & $\mathrm{Zn}_{\text {excreted }}\left(\Phi_{\mathrm{nc}}\right)(\mathrm{kg})=\mathrm{Zn}_{\text {intake }}\left(\Phi_{\mathrm{nc}}\right)-\mathrm{Zn}_{\text {retained }}$ \\
\hline \multirow[t]{2}{*}{ Equation PO-13 } & $\mathrm{N}_{2} \mathrm{O}_{\text {manure }}\left(\Phi_{\mathrm{nc}}\right)(\mathrm{kg})=\mathrm{N}_{\text {excreted }}\left(\Phi_{\mathrm{nc}}\right) \times \mathrm{EF}_{\mathrm{MMS}} \times 44 / 28$ \\
\hline & Intensity \\
\hline Equation PO-14 & $\mathrm{N}_{\text {excreted }}$ Intensity $\left(\Phi_{\mathrm{nc}}\right)(\mathrm{kg} / \mathrm{kg}$ eggs in shell $)=\mathrm{N}_{\text {excreted }}\left(\Phi_{\mathrm{nc}}\right) / \mathrm{kg}$ eggs in shell \\
\hline Equation FA-15 & $\mathrm{P}_{\text {excreted }}$ Intensity $\left(\Phi_{\mathrm{nc}}\right)(\mathrm{kg} / \mathrm{kg}$ eggs in shell $)=\mathrm{P}_{\text {excreted }}\left(\Phi_{\mathrm{nc}}\right) / \mathrm{kg}$ eggs in shell \\
\hline Equation FA-16 & $\mathrm{Cu}_{\text {excreted }}$ Intensity $\left(\Phi_{\mathrm{nc}}\right)(\mathrm{kg} / \mathrm{kg}$ eggs in shell $)=\mathrm{Cu}_{\text {excreted }}\left(\Phi_{\mathrm{nc}}\right) / \mathrm{kg}$ eggs in shell \\
\hline Equation FA-17 & $\mathrm{Zn}_{\text {excreted }}$ Intensity $\left(\Phi_{\mathrm{nc}}\right)(\mathrm{kg} / \mathrm{kg}$ eggs in shell $)=\mathrm{Zn}_{\text {excreted }}\left(\Phi_{\mathrm{nc}}\right) / \mathrm{kg}$ eggs in shell \\
\hline Equation PO-19 & $\mathrm{N}_{2} \mathrm{O}_{\text {manure }}$ Intensity $\left(\Phi_{\mathrm{nc}}\right)(\mathrm{kg} / \mathrm{kg}$ eggs in shell $)=\mathrm{N}_{2} \mathrm{O}_{\text {manure }}\left(\Phi_{\mathrm{nc}}\right) / \mathrm{kg}$ eggs in shell \\
\hline
\end{tabular}

When a feed additive or combination of feed additives modifies the feed efficiency of laying birds, it could be through a modification of one or more of the following:

- feed intake $\left(\Phi_{\mathrm{fi}}\right)$ (Table 47)

- egg in shell production $\left(\Phi_{\text {ep }}\right)$ (Table 48)

- modification of the egg composition $\left(\Phi_{\mathrm{ec}}\right)$ (Table 49)

In the case that the feed additive or combination of feed additives has an impact on more than one of the above-mentioned parameters, it is advised to combine the different impact accordingly. For example, if the feed additive or combination of feed additives modifies the feed intake $\left(\Phi_{\mathrm{f}}\right)$ and the weight gain $\left(\Phi_{\mathrm{wg}}\right)$, the phosphorus balance will be recalculated as follows: 
- $\mathrm{P}_{\text {intake }}\left(\Phi_{\mathrm{fi}}\right)(\mathrm{kg})=\Sigma\left(\mathrm{FI}_{\mathrm{Ph}} \times \Phi_{\mathrm{fi}} \times\left(\% \mathrm{P}_{\text {totalPh }} / 100\right)\right)($ Equation FA-1 adapted $)$

- $\mathrm{P}_{\text {retention }}\left(\Phi_{\text {ep }}\right)(\mathrm{kg})=\left(\mathrm{TWG} \times \Phi_{\text {ew }} \times \% \mathrm{P}\right.$ in tissues and bones/100) (Equation FA-2 adapted)

This will lead to a modification of the phosphorus excretion.

Table 47: Adaptation of equations for laying birds (change in feed intake)

\begin{tabular}{|c|c|}
\hline & Basis for calculation \\
\hline Equation FA-1 & $\mathrm{P}_{\text {intake }}\left(\Phi_{\mathrm{fi}}\right)(\mathrm{kg})=\Sigma\left(\mathrm{FI}_{\mathrm{Ph}} \times \Phi_{\mathrm{fi}} \times \% \mathrm{P}_{\text {totalPh }}\right) / 100$ \\
\hline Equation FA-3 & $\mathrm{Cu}_{\text {intake }}\left(\Phi_{\mathrm{fi}}\right)(\mathrm{kg})=\Sigma\left(\mathrm{FI}_{\mathrm{Ph}} \times \Phi_{\mathrm{fi}} \times \% \mathrm{Cu}_{\mathrm{Ph}}\right) / 100$ \\
\hline Equation FA-5 & $\mathrm{Zn}_{\text {intake }}\left(\Phi_{\mathrm{fi}}\right)(\mathrm{kg})=\Sigma\left(\mathrm{FI}_{\mathrm{Ph}} \times \Phi_{\mathrm{fi}} \times \% \mathrm{Zn}_{\mathrm{Ph}}\right) / 100$ \\
\hline \multirow[t]{3}{*}{ Equation PO-7 } & $\operatorname{VS}\left(\Phi_{\mathrm{fi}}\right)(\mathrm{kg})=\Sigma\left(\mathrm{FI}_{\mathrm{Ph}} \times \Phi_{\mathrm{fi}} \times(1-\mathrm{DMD}) \times(1-\mathrm{A})\right)$ \\
\hline & Calculated impacts \\
\hline & Total \\
\hline Equation PO-8 & $\mathrm{N}_{\text {excreted }}\left(\Phi_{\mathrm{fi}}\right)(\mathrm{kg})=\Sigma\left(\mathrm{FI}_{\mathrm{Ph}} \times \Phi_{\mathrm{fi}} \times \% \mathrm{CP}_{\mathrm{Ph}} / 100\right) / 6.25 \times((0.0182 \times \mathrm{EW}) \times \mathrm{ENb})$ \\
\hline Equation FA-9 & $\mathrm{P}_{\text {excreted }}\left(\Phi_{\mathrm{fi}}\right)(\mathrm{kg})=\mathrm{P}_{\text {intake }}\left(\Phi_{\mathrm{fi}}\right)-\mathrm{P}_{\text {retained }}$ \\
\hline Equation FA-10 & $\mathrm{Cu}_{\text {excreted }}\left(\Phi_{\mathrm{fi}}\right)(\mathrm{kg})=\mathrm{Cu}_{\text {intake }}\left(\Phi_{\mathrm{fi}}\right)-\mathrm{Cu}_{\text {retained }}$ \\
\hline Equation FA-11 & $\mathrm{Zn}_{\text {excreted }}\left(\Phi_{\mathrm{fi}}\right)(\mathrm{kg})=\mathrm{Zn}_{\text {intake }}\left(\Phi_{\mathrm{fi}}\right)-\mathrm{Zn}_{\text {retained }}$ \\
\hline Equation PO-12 & $\mathrm{CH}_{4 \text { manure }}\left(\Phi_{\mathrm{fi}}\right)(\mathrm{kg})=\mathrm{VS}\left(\Phi_{\mathrm{fi}}\right) \times \mathrm{Bo} \times \mathrm{MCF} \times 0.662$ \\
\hline \multirow[t]{2}{*}{ Equation PO-13 } & $\mathrm{N}_{2} \mathrm{O}_{\text {manure }}\left(\Phi_{\mathrm{fi}}\right)(\mathrm{kg})=\mathrm{N}_{\text {excreted }}\left(\Phi_{\mathrm{fi}}\right) \times \mathrm{EF}_{\text {MMS }} \times 44 / 28$ \\
\hline & Intensity \\
\hline Equation PO-14 & $\mathrm{N}_{\text {excreted }}$ Intensity $\left(\Phi_{\mathrm{f}}\right)(\mathrm{kg} / \mathrm{kg}$ eggs in shell $)=\mathrm{N}_{\text {excreted }}\left(\Phi_{\mathrm{fi}}\right) / \mathrm{kg}$ eggs in shell \\
\hline Equation FA-15 & $\mathrm{P}_{\text {excreted }}$ Intensity $\left(\Phi_{\mathrm{fi}}\right)(\mathrm{kg} / \mathrm{kg}$ eggs in shell $)=\mathrm{P}_{\text {excreted }}\left(\Phi_{\mathrm{fi}}\right) / \mathrm{kg}$ eggs in shell \\
\hline Equation FA-16 & $\mathrm{Cu}_{\text {excreted }}$ Intensity $\left(\Phi_{\mathrm{fi}}\right)(\mathrm{kg} / \mathrm{kg}$ eggs in shell $)=\mathrm{Cu}_{\text {excreted }}\left(\Phi_{\mathrm{fi}}\right) / \mathrm{kg}$ eggs in shell \\
\hline Equation FA-17 & $\mathrm{Zn}_{\text {excreted }}$ Intensity $\left(\Phi_{\mathrm{fi}}\right)(\mathrm{kg} / \mathrm{kg}$ eggs in shell $)=\mathrm{Zn}_{\text {excreted }}\left(\Phi_{\mathrm{fi}}\right) / \mathrm{kg}$ eggs in shell \\
\hline Equation PO-18 & $\mathrm{CH}_{4 \text { manure }}$ Intensity $\left(\Phi_{\mathrm{fi}}\right)(\mathrm{kg} / \mathrm{kg}$ eggs in shell $)=\mathrm{CH}_{4 \text { manure }}\left(\Phi_{\mathrm{fi}}\right) / \mathrm{kg}$ eggs in shell \\
\hline Equation PO-19 & $\mathrm{N}_{2} \mathrm{O}_{\text {manure }}$ Intensity $\left(\Phi_{\mathrm{fi}}\right)(\mathrm{kg} / \mathrm{kg}$ eggs in shell $)=\mathrm{N}_{2} \mathrm{O}_{\text {manure }}\left(\Phi_{\mathrm{fi}}\right) / \mathrm{kg}$ eggs in shell \\
\hline
\end{tabular}

Note: $\Phi_{\mathrm{fi}}=$ change in feed intake; subscript Ph means the growing phase (e.g. \% $\mathrm{Cu}_{\mathrm{Ph}}$ represents the copper content of the feed during a specific growing phase such as starter).

In the case of a modification of the animal performance, the production of eggs in shell is modified as follows:

kg eggs in shell $\left(\Phi_{\text {ep }}\right)=\mathrm{EW} \times \Phi_{\text {ep }} \times \mathrm{ENb} \times \Phi_{\text {ep }}$

Hence the emission intensity is modified.

Table 48: Adaptation of equations for laying birds (change in growth performance)

\begin{tabular}{|c|c|}
\hline & Basis for calculation \\
\hline Equation FA-2 & $\mathrm{P}_{\text {retention }}\left(\Phi_{\mathrm{ep}}\right)(\mathrm{kg})=\mathrm{EW} \times \Phi_{\mathrm{ep}} \times \mathrm{ENb} \times \Phi_{\mathrm{ep}} \times \% \mathrm{P}$ eggs $/ 100$ \\
\hline Equation FA-4 & $\mathrm{Cu}_{\text {retention }}\left(\Phi_{\mathrm{ep}}\right)(\mathrm{kg})=\mathrm{EW} \times \Phi_{\mathrm{ep}} \times \mathrm{ENb} \times \Phi_{\mathrm{ep}} \times \% \mathrm{Cu}$ eggs $/ 100$ \\
\hline \multirow[t]{3}{*}{ Equation FA-6 } & $\mathrm{Zn}_{\text {retention }}\left(\Phi_{\mathrm{ep}}\right)(\mathrm{kg})=\mathrm{EW} \times \Phi_{\mathrm{ep}} \times \mathrm{ENb} \times \Phi_{\mathrm{ep}} \times \% \mathrm{Zn}$ eggs $/ 100$ \\
\hline & Calculated impacts \\
\hline & Total \\
\hline Equation PO-8 & $\mathrm{N}_{\text {excreted }}\left(\Phi_{\mathrm{ep}}\right)(\mathrm{kg})=\Sigma\left(\mathrm{FI}_{\mathrm{Ph}} \times \% \mathrm{CP}_{\mathrm{Ph}} / 100\right) / 6.25 \times\left(\left(0.0182 \times \mathrm{EW} \times \Phi_{\mathrm{ep}}\right) \times \mathrm{ENb}\right)$ \\
\hline Equation FA-9 & $\mathrm{P}_{\text {excreted }}\left(\Phi_{\mathrm{ep}}\right)(\mathrm{kg})=\mathrm{P}_{\text {intake }}-\mathrm{P}_{\text {retained }}\left(\Phi_{\mathrm{ep}}\right)$ \\
\hline Equation FA-10 & $\mathrm{Cu}_{\text {excreted }}\left(\Phi_{\mathrm{ep}}\right)(\mathrm{kg})=\mathrm{Cu}_{\text {intake }}-\mathrm{Cu}_{\text {retained }}\left(\Phi_{\mathrm{ep}}\right)$ \\
\hline Equation FA-11 & $\mathrm{Zn}_{\text {excreted }}\left(\Phi_{\text {ep }}\right)(\mathrm{kg})=\mathrm{Zn}_{\text {intake }}-\mathrm{Zn}_{\text {retained }}\left(\Phi_{\text {ep }}\right)$ \\
\hline Equation PO-13 & $\mathrm{N}_{2} \mathrm{O}_{\text {manure }}\left(\Phi_{\mathrm{ep}}\right)(\mathrm{kg})=\mathrm{N}_{\text {excreted }}\left(\Phi_{\mathrm{ep}}\right) \times \mathrm{EF}_{\mathrm{MMS}} \times 44 / 28$ \\
\hline
\end{tabular}




\begin{tabular}{lc}
\hline & Intensity \\
\hline Equation PO-14 & $\mathrm{N}_{\text {excreted }}$ Intensity $\left(\Phi_{\text {ep }}\right)(\mathrm{kg} / \mathrm{kg}$ eggs in shell $)=\mathrm{N}_{\text {excreted }}\left(\Phi_{\text {ep }}\right) / \mathrm{kg}$ eggs in shell $\left(\Phi_{\text {ep }}\right)$ \\
\hline Equation FA-15 & $\mathrm{P}_{\text {excreted }}$ Intensity $\left(\Phi_{\mathrm{ep}}\right)(\mathrm{kg} / \mathrm{kg}$ eggs in shell $)=\mathrm{P}_{\text {excreted }}\left(\Phi_{\text {ep }}\right) / \mathrm{kg}$ eggs in shell $\left(\Phi_{\text {ep }}\right)$ \\
\hline Equation FA-16 & $\mathrm{Cu}_{\text {excreted }}$ Intensity $\left(\Phi_{\mathrm{ep}}\right)(\mathrm{kg} / \mathrm{kg}$ eggs in shell $)=\mathrm{Cu}_{\text {excreted }}\left(\Phi_{\text {ep }}\right) / \mathrm{kg}$ eggs in shell $\left(\Phi_{\text {ep }}\right)$ \\
\hline Equation FA-17 & $\mathrm{Zn}_{\text {excreted }}$ Intensity $\left(\Phi_{\mathrm{ep}}\right)(\mathrm{kg} / \mathrm{kg}$ eggs in shell $)=\mathrm{Zn}_{\text {excreted }}\left(\Phi_{\mathrm{ep}}\right) / \mathrm{kg}$ eggs in shell $\left(\Phi_{\mathrm{ep}}\right)$ \\
\hline Equation PO-19 & $\mathrm{N}_{2} \mathrm{O}_{\text {manure }}$ Intensity $\left(\Phi_{\mathrm{ep}}\right)(\mathrm{kg} / \mathrm{kg}$ eggs in shell $)=\mathrm{N}_{2} \mathrm{O}_{\text {manure }}\left(\Phi_{\mathrm{ep}}\right) / \mathrm{kg}$ eggs in shell $\left(\Phi_{\mathrm{ep}}\right)$ \\
\hline Note: $\Phi_{\mathrm{ep}}=$ change in growth performance.
\end{tabular}

When the feed additive or the combination of feed additives modifies the egg composition, the factor $\Phi_{\mathrm{ec}}$ is used in the equations (Table 49). It should be noted that the factor might be different for the changes observed (e.g. $\Phi_{\mathrm{ec}}$ can be 1.05 for change in protein concentration and 0.98 for change in phosphorus concentration).

Table 49: Adaptation of equations for laying birds (change in body weight gain composition)

\begin{tabular}{|c|c|}
\hline & Basis for calculation \\
\hline Equation FA-2 & $P_{\text {retention }}\left(\Phi_{\mathrm{ec}}\right)(\mathrm{kg})=\mathrm{EW} \times \mathrm{ENb} \times \% \mathrm{P}$ eggs $\times \Phi_{\mathrm{ec}} / 100$ \\
\hline Equation FA-4 & $\mathrm{Cu}_{\text {retention }}\left(\Phi_{\mathrm{ec}}\right)(\mathrm{kg})=\mathrm{EW} \times \mathrm{ENb} \times \% \mathrm{Cu}$ eggs $\times \Phi_{\mathrm{ec}} / 100$ \\
\hline \multirow[t]{3}{*}{ Equation FA-6 } & $\mathrm{Zn}_{\text {retention }}\left(\Phi_{\mathrm{ec}}\right)(\mathrm{kg})=\mathrm{EW} \times \mathrm{ENb} \times \% \mathrm{Zn}$ eggs $\times \Phi_{\mathrm{ec}} / 100$ \\
\hline & Calculated impacts \\
\hline & Total \\
\hline Equation PO-8 & $\mathrm{N}_{\text {excreted }}\left(\Phi_{\mathrm{ec}}\right)(\mathrm{kg})=\Sigma\left(\mathrm{FI}_{\mathrm{Ph}} \times \% \mathrm{CP}_{\mathrm{Ph}} / 100\right) / 6.25 \times\left(\left(0.0182 \times \Phi_{\mathrm{ec}} \times \mathrm{EW}\right) \times \mathrm{ENb}\right)$ \\
\hline Equation FA-9 & $\mathrm{P}_{\text {excreted }}\left(\Phi_{\mathrm{ec}}\right)(\mathrm{kg})=\mathrm{P}_{\text {intake }}-\mathrm{P}_{\text {retained }}\left(\Phi_{\mathrm{ec}}\right)$ \\
\hline Equation FA-10 & $\mathrm{Cu}_{\text {excreted }}\left(\Phi_{\mathrm{ec}}\right)(\mathrm{kg})=\mathrm{Cu}_{\text {intake }}-\mathrm{Cu}_{\text {retained }}\left(\Phi_{\mathrm{ec}}\right)$ \\
\hline Equation FA-11 & $\mathrm{Zn}_{\text {excreted }}\left(\Phi_{\text {ec }}\right)(\mathrm{kg})=\mathrm{Zn}_{\text {intake }}-\mathrm{Zn}_{\text {retained }}\left(\Phi_{\text {ec }}\right)$ \\
\hline \multirow[t]{2}{*}{ Equation PO-13 } & $\mathrm{N}_{2} \mathrm{O}_{\text {manure }}\left(\Phi_{\mathrm{ec}}\right)(\mathrm{kg})=\mathrm{N}_{\text {excreted }}\left(\Phi_{\mathrm{ec}}\right) \times \mathrm{EF}_{\mathrm{MMS}} \times 44 / 28$ \\
\hline & Intensity \\
\hline Equation PO-14 & $\mathrm{N}_{\text {excreted }}$ Intensity $\left(\Phi_{\mathrm{ec}}\right)(\mathrm{kg} / \mathrm{kg}$ eggs in shell $)=\mathrm{N}_{\text {excreted }}\left(\Phi_{\mathrm{ec}}\right) / \mathrm{kg}$ eggs in shell \\
\hline Equation FA-15 & $\mathrm{P}_{\text {excreted }}$ Intensity $\left(\Phi_{\mathrm{ec}}\right)(\mathrm{kg} / \mathrm{kg}$ eggs in shell $)=\mathrm{P}_{\text {excreted }}\left(\Phi_{\mathrm{ec}}\right) / \mathrm{kg}$ eggs in shell \\
\hline Equation FA-16 & $\mathrm{Cu}_{\text {excreted }}$ Intensity $\left(\Phi_{\mathrm{ec}}\right)(\mathrm{kg} / \mathrm{kg}$ eggs in shell $)=\mathrm{Cu}_{\text {excreted }}\left(\Phi_{\mathrm{ec}}\right) / \mathrm{kg}$ eggs in shell \\
\hline Equation FA-17 & $\mathrm{Zn}_{\text {excreted }}$ Intensity $\left(\Phi_{\text {ec }}\right)(\mathrm{kg} / \mathrm{kg}$ eggs in shell $)=\mathrm{Zn}_{\text {excreted }}\left(\Phi_{\mathrm{ec}}\right) / \mathrm{kg}$ eggs in shell \\
\hline Equation PO-19 & $\mathrm{N}_{2} \mathrm{O}_{\text {manure }}$ Intensity $\left(\Phi_{\mathrm{ec}}\right)(\mathrm{kg} / \mathrm{kg}$ eggs in shell $)=\mathrm{N}_{2} \mathrm{O}_{\text {manure }}\left(\Phi_{\mathrm{ec}}\right) / \mathrm{kg}$ eggs in shell \\
\hline
\end{tabular}

When the feed additive or combination of additives has a direct effect on methane $\left(\mathrm{CH}_{4}\right)$ or nitrous oxide $\left(\mathrm{N}_{2} \mathrm{O}\right)$ emissions, the factor $\Phi_{\text {ef }}$ is used for the modification of the emission factor in the relevant equations. Although the factor is named in the same way in the equations $\left(\Phi_{\mathrm{ef}}\right)$, it will differ for the relevant emissions. 
Table 50: Adaptation of equations for laying birds (change in emission factor)

\begin{tabular}{lc} 
& Calculated impacts \\
\hline Equation PO-12 & $\mathrm{CH}_{4 \text { manure }}\left(\Phi_{\mathrm{ef}}\right)(\mathrm{kg})=\mathrm{VS} \times \mathrm{Bo} \times \mathrm{MCF}\left(\Phi_{\mathrm{ef}}\right) \times 0.662$ \\
\hline Equation PO-13 & $\mathrm{N}_{2} \mathrm{O}_{\text {manure }}\left(\Phi_{\mathrm{ef}}\right)(\mathrm{kg})=\mathrm{N}_{\text {excreted }} \times \mathrm{EF}_{\mathrm{MMS}}\left(\Phi_{\mathrm{ef}}\right) \times 44 / 28$ \\
\hline & Intensity \\
\hline Equation PO-18 & $\mathrm{CH}_{4 \text { manure }}$ Intensity $\left(\Phi_{\mathrm{ef}}\right)(\mathrm{kg} / \mathrm{kg}$ eggs in shell $)=\mathrm{CH}_{4 \text { manure }}\left(\Phi_{\mathrm{ef}}\right) / \mathrm{kg}$ eggs in shell \\
\hline Equation PO-19 & $\mathrm{N}_{2} \mathrm{O}_{\text {manure }}$ Intensity $\left(\Phi_{\mathrm{ef}}\right)(\mathrm{kg} / \mathrm{kg}$ eggs in shell $)=\mathrm{N}_{2} \mathrm{O}_{\text {manure }}\left(\Phi_{\mathrm{ef}}\right) / \mathrm{kg}$ eggs in shell \\
\hline
\end{tabular}

Note: $\Phi_{\mathrm{ef}}=$ change in emission factor.

\section{ix. Poultry (breeding birds) \\ Baseline scenario}

Table 51 lists the equations relevant for the evaluation of the environmental impact of breeding birds for the baseline scenario. The equations originating from the LEAP poultry guidelines (FAO, 2016d) are noted "Equation PO-n". For consistency with the other species and while the detailed equations are not available in the poultry guidelines, additional equations are included, noted "Equation FA-n". The calculated impacts will be the comparison point for the feed additive scenario. Definitions of parameters and variables used in the equations are given in Table 2.

The breeding birds' production comprises different phases (start of lay, end of lay). The consideration of the different phase is noted as $\mathrm{Ph}$. When calculating the impact, the sum of the impacts during the different phases should be calculated.

Table 51: Equations used for evaluating the baseline emissions for breeding birds

\begin{tabular}{|c|c|}
\hline & Basis for calculation \\
\hline Equation FA-1 & $P_{\text {intake }}(\mathrm{kg})=\Sigma\left(\mathrm{FI}_{\mathrm{Ph}} \times \% \mathrm{P}_{\text {totalPh }}\right) / 100$ \\
\hline Equation FA-2 & $\mathrm{P}_{\text {retention }}(\mathrm{kg})=\mathrm{EW} \times \mathrm{ENb} \times \% \mathrm{P}$ eggs $/ 100$ \\
\hline Equation FA-3 & $\mathrm{Cu}_{\text {intake }}(\mathrm{kg})=\Sigma\left(\mathrm{FI}_{\mathrm{Ph}} \times \% \mathrm{Cu}_{\mathrm{Ph}}\right) / 100$ \\
\hline Equation FA-4 & $\mathrm{Cu}_{\text {retention }}(\mathrm{kg})=\mathrm{EW} \times \mathrm{ENb} \times \% \mathrm{Cu}$ eggs $/ 100$ \\
\hline Equation FA-5 & $\mathrm{Zn}_{\text {intake }}(\mathrm{kg})=\Sigma\left(\mathrm{FI}_{\mathrm{Ph}} \times \% \mathrm{Zn}_{\mathrm{Ph}}\right) / 100$ \\
\hline Equation FA-6 & $\mathrm{Zn}_{\text {retention }}(\mathrm{kg})=\mathrm{EW} \times \mathrm{ENb} \times \% \mathrm{Zn}$ eggs \\
\hline \multirow[t]{3}{*}{ Equation PO-7 } & $\operatorname{VS}(\mathrm{kg})=\Sigma\left(\mathrm{FI}_{\mathrm{Ph}} \times(1-\mathrm{DMD}) \times(1-\mathrm{A})\right)$ \\
\hline & Calculated impacts \\
\hline & Total \\
\hline Equation PO-8 & $\mathrm{N}_{\text {excreted }}(\mathrm{kg})=\Sigma\left(\mathrm{FI}_{\mathrm{Ph}} \times \% \mathrm{CP}_{\mathrm{Ph}} / 100\right) / 6.25 \times((0.0182 \times \mathrm{EW}) \times \mathrm{ENb})$ \\
\hline Equation FA-9 & $\mathrm{P}_{\text {excreted }}(\mathrm{kg})=\mathrm{P}_{\text {intake }}-\mathrm{P}_{\text {retention }}$ \\
\hline Equation FA-10 & $\mathrm{Cu}_{\text {excreted }}(\mathrm{kg})=\mathrm{Cu}_{\text {intake }}-\mathrm{Cu}_{\text {retention }}$ \\
\hline Equation FA-11 & $\mathrm{Zn}_{\text {excreted }}(\mathrm{kg})=\mathrm{Zn}_{\text {intake }}-\mathrm{Zn}_{\text {retention }}$ \\
\hline Equation PO-12 & $\mathrm{CH}_{4 \text { manure }}(\mathrm{kg})=\mathrm{VS} \times \mathrm{Bo} \times \mathrm{MCF} \times 0.662$ \\
\hline \multirow[t]{2}{*}{ Equation PO-13 } & $\mathrm{N}_{2} \mathrm{O}_{\text {manure }}(\mathrm{kg})=\mathrm{N}_{\text {excreted }} \times \mathrm{EF}_{\text {MMS }} \times 44 / 28$ \\
\hline & Intensity \\
\hline Equation PO-14 & $\mathrm{N}_{\text {excreted }}$ Intensity (kg/no. hatched eggs) $=\mathrm{N}_{\text {excreted }} /$ no. hatched eggs \\
\hline Equation FA-15 & $\mathrm{P}_{\text {excreted }}$ Intensity $(\mathrm{kg} / \mathrm{no}$. hatched eggs $)=\mathrm{P}_{\text {excreted }} /$ no. hatched eggs \\
\hline Equation FA-16 & $\mathrm{Cu}_{\text {excreted }}$ Intensity $\left(\mathrm{kg} / \mathrm{no}\right.$. hatched eggs) $=\mathrm{Cu}_{\text {excreted }} /$ no. hatched eggs \\
\hline Equation FA-17 & $\mathrm{Zn}_{\text {excreted }}$ Intensity $(\mathrm{kg} / \mathrm{no}$. hatched eggs $)=\mathrm{Zn}_{\text {excreted }} /$ no. hatched eggs \\
\hline Equation PO-18 & $\mathrm{CH}_{4 \text { manure }}$ Intensity $(\mathrm{kg} / \mathrm{no}$. hatched eggs $)=\mathrm{CH}_{4 \text { manure }} /$ no. hatched eggs \\
\hline Equation PO-19 & $\mathrm{N}_{2} \mathrm{O}_{\text {manure }}$ Intensity $(\mathrm{kg} / \mathrm{no}$. hatched eggs $)=\mathrm{N}_{2} \mathrm{O}_{\text {manure }} /$ no. hatched eggs \\
\hline
\end{tabular}




\section{Feed additive scenarios}

Tables 52-55 provide the changes in the equations linked to the effect of the feed additive or combination of feed additives on the parameters. Each table provides information on the potential effects of the feed additive or combination of feed additives (subsection 6.10 .3 [i-iii]) as follows:

- modification of feed composition (Table 52)

- feed efficiency (Tables 53, 54)

- emission factors (Table 55)

When the change in the equations used as a basis for the calculation (upper part of the tables) modifies the calculated impact, the corresponding equations are also indicated (lower part of the tables). For example, when the concentration of nitrogen is changed in the diet (use of the factor $\Phi_{n c}$ ), the result of both the $\mathrm{N}_{\text {intake }}$ and the $\mathrm{N}_{\text {excreted }}$ is changed. Hence these equations are also indicated. It should be noted that the factor might be different for the changes observed (e.g. $\Phi_{\mathrm{nc}}$ can be 1.05 for change in protein concentration and 0.98 for change in phosphorus concentration).

Table 52: Adaptation of equations for breeding birds (change in feed composition)

\begin{tabular}{|c|c|}
\hline & Basis for calculation \\
\hline Equation FA-1 & $\mathrm{P}_{\text {intake }}\left(\Phi_{\mathrm{nc}}\right)(\mathrm{kg})=\Sigma\left(\mathrm{FI}_{\mathrm{Ph}} \times \% \mathrm{P}_{\text {totalPh }} \times \Phi_{\mathrm{nc}}\right) / 100$ \\
\hline Equation FA-3 & $\mathrm{Cu}_{\text {intake }}\left(\Phi_{\mathrm{nc}}\right)(\mathrm{kg})=\Sigma\left(\mathrm{FI}_{\mathrm{Ph}} \times \% \mathrm{Cu}_{\mathrm{Ph}} \times \Phi_{\mathrm{nc}}\right) / 100$ \\
\hline \multirow[t]{3}{*}{ Equation FA-5 } & $\mathrm{Zn}_{\text {intake }}\left(\Phi_{\mathrm{nc}}\right)(\mathrm{kg})=\Sigma\left(\mathrm{FI}_{\mathrm{Ph}} \times \% \mathrm{Zn}_{\mathrm{Ph}} \times \Phi_{\mathrm{nc}}\right) / 100$ \\
\hline & Calculated impacts \\
\hline & Total \\
\hline Equation PO-8 & $\mathrm{N}_{\text {excreted }}\left(\Phi_{\mathrm{nc}}\right)(\mathrm{kg})=\Sigma\left(\mathrm{FI}_{\mathrm{Ph}} \times \% \mathrm{CP}_{\mathrm{Ph}} \times \Phi_{\mathrm{nc}} / 100\right) / 6.25 \times((0.0182 \times \mathrm{EW}) \times \mathrm{ENb})$ \\
\hline Equation FA-9 & $\mathrm{P}_{\text {excreted }}\left(\Phi_{\mathrm{nc}}\right)(\mathrm{kg})=\mathrm{P}_{\text {intake }}\left(\Phi_{\mathrm{nc}}\right)-\mathrm{P}_{\text {retention }}$ \\
\hline Equation FA-10 & $\mathrm{Cu}_{\text {excreted }}\left(\Phi_{\mathrm{nc}}\right)(\mathrm{kg})=\mathrm{Cu}_{\text {intake }}\left(\Phi_{\mathrm{nc}}\right)-\mathrm{Cu}_{\text {retention }}$ \\
\hline Equation FA-11 & $\mathrm{Zn}_{\text {excreted }}\left(\Phi_{\mathrm{nc}}\right)(\mathrm{kg})=\mathrm{Zn}_{\text {intake }}\left(\Phi_{\mathrm{nc}}\right)-\mathrm{Zn}_{\text {retention }}$ \\
\hline \multirow[t]{2}{*}{ Equation PO-13 } & $\mathrm{N}_{2} \mathrm{O}_{\text {manure }}\left(\Phi_{\mathrm{nc}}\right)(\mathrm{kg})=\mathrm{N}_{\text {excreted }}\left(\Phi_{\mathrm{nc}}\right) \times \mathrm{EF}_{\mathrm{MMS}} \times 44 / 28$ \\
\hline & Intensity \\
\hline Equation PO-14 & $\mathrm{N}_{\text {excreted }}$ Intensity $\left(\Phi_{\mathrm{nc}}\right)(\mathrm{kg} / \mathrm{no}$. hatched eggs $)=\mathrm{N}_{\text {excreted }}\left(\Phi_{\mathrm{nc}}\right) /$ no. hatched eggs \\
\hline Equation FA-15 & $\mathrm{P}_{\text {excreted }}$ Intensity $\left(\Phi_{\mathrm{nc}}\right)(\mathrm{kg} / \mathrm{no}$. hatched eggs $)=\mathrm{P}_{\text {excreted }}\left(\Phi_{\mathrm{nc}}\right) /$ no. hatched eggs \\
\hline Equation FA-16 & $\mathrm{Cu}_{\text {excreted }}$ Intensity $\left(\Phi_{\mathrm{nc}}\right)(\mathrm{kg} / \mathrm{no}$. hatched eggs $)=\mathrm{Cu}_{\text {excreted }}\left(\Phi_{\mathrm{nc}}\right) /$ no. hatched eggs \\
\hline Equation FA-17 & $\mathrm{Zn}_{\text {excreted }}$ Intensity $\left(\Phi_{\mathrm{nc}}\right)(\mathrm{kg} / \mathrm{no}$. hatched eggs $)=\mathrm{Zn}_{\text {excreted }}\left(\Phi_{\mathrm{nc}}\right) /$ no. hatched eggs \\
\hline Equation PO-19 & $\mathrm{N}_{2} \mathrm{O}_{\text {manure }}$ Intensity $\left(\Phi_{\mathrm{nc}}\right)(\mathrm{kg} / \mathrm{no}$. hatched eggs $)=\mathrm{N}_{2} \mathrm{O}_{\text {manure }}\left(\Phi_{\mathrm{nc}}\right) /$ no. hatched eggs \\
\hline
\end{tabular}

Note: $\Phi_{\mathrm{nc}}=$ change in feed composition (protein, phosphorus, copper and zinc content); subscript Ph means the growing phase (e.g. \% $\mathrm{Cu}_{\mathrm{Ph}}$ represents the copper content of the feed during a specific growing phase such as starter).

When the feed additive or combination of feed additives modifies the feed efficiency of breeding birds, it could be through modification of one or both of the following:

- feed intake $\left(\Phi_{\mathrm{fi}}\right)$ (Table 53)

- no. hatched eggs $\left(\Phi_{\text {he }}\right)$ (Table 54) 
Table 53: Adaptation of equations for breeding birds (change in feed intake)

\begin{tabular}{|c|c|}
\hline & Basis for calculation \\
\hline Equation FA-1 & $P_{\text {intake }}\left(\Phi_{\mathrm{fi}}\right)(\mathrm{kg})=\Sigma\left(\mathrm{FI}_{\mathrm{Ph}} \times \Phi_{\mathrm{fi}} \times \% \mathrm{P}_{\text {totalPh }}\right) / 100$ \\
\hline Equation FA-3 & $\mathrm{Cu}_{\text {intake }}\left(\Phi_{\mathrm{fi}}\right)(\mathrm{kg})=\Sigma\left(\mathrm{FI}_{\mathrm{Ph}} \times \mathrm{F}_{\mathrm{fi}} \times \% \mathrm{Cu}_{\mathrm{Ph}}\right) / 100$ \\
\hline Equation FA-5 & $\mathrm{Zn}_{\text {intake }}\left(\Phi_{\mathrm{fi}}\right)(\mathrm{kg})=\Sigma\left(\mathrm{FI}_{\mathrm{Ph}} \times \Phi_{\mathrm{fi}} \times \% \mathrm{Zn}_{\mathrm{Ph}}\right) / 100$ \\
\hline \multirow[t]{3}{*}{ Equation PO-7 } & $\operatorname{VS}\left(\Phi_{\mathrm{fi}}\right)(\mathrm{kg})=\Sigma\left(\mathrm{FI}_{\mathrm{Ph}} \times \Phi_{\mathrm{fi}} \times(1-\mathrm{DMD}) \times(1-\mathrm{A})\right)$ \\
\hline & Calculated impacts \\
\hline & Total \\
\hline Equation PO-8 & $\mathrm{N}_{\text {excreted }}\left(\Phi_{\mathrm{fi}}\right)(\mathrm{kg})=\Sigma\left(\mathrm{FI}_{\mathrm{Ph}} \times \Phi_{\mathrm{fi}} \times \% \mathrm{CP}_{\mathrm{Ph}} / 100\right) / 6.25 \times((0.0182 \times \mathrm{EW}) \times \mathrm{ENb})$ \\
\hline Equation FA-9 & $\mathrm{P}_{\text {excreted }}\left(\Phi_{\mathrm{fi}}\right)(\mathrm{kg})=\mathrm{P}_{\text {intake }}\left(\Phi_{\mathrm{fi}}\right)-\mathrm{P}_{\text {retention }}$ \\
\hline Equation FA-10 & $\mathrm{Cu}_{\text {excreted }}\left(\Phi_{\mathrm{fi}}\right)(\mathrm{kg})=\mathrm{Cu}_{\text {intake }}\left(\Phi_{\mathrm{fi}}\right)-\mathrm{Cu}_{\text {retention }}$ \\
\hline Equation FA-11 & $\mathrm{Zn}_{\text {excreted }}\left(\Phi_{\mathrm{fi}}\right)(\mathrm{kg})=\mathrm{Zn}_{\text {intake }}\left(\Phi_{\mathrm{fi}}\right)-\mathrm{Zn}_{\text {retention }}$ \\
\hline Equation PO-12 & $\mathrm{CH}_{4 \text { manure }}\left(\Phi_{\mathrm{fi}}\right)(\mathrm{kg})=\mathrm{VS}\left(\Phi_{\mathrm{fi}}\right) \times \mathrm{Bo} \times \mathrm{MCF} \times 0.662$ \\
\hline \multirow[t]{2}{*}{ Equation PO-13 } & $\mathrm{N}_{2} \mathrm{O}_{\text {manure }}\left(\Phi_{\mathrm{f}}\right)(\mathrm{kg})=\mathrm{N}_{\text {excreted }}\left(\Phi_{\mathrm{fi}}\right) \times \mathrm{EF}_{\mathrm{MMS}} \times 44 / 28$ \\
\hline & Intensity \\
\hline Equation $\mathrm{PO}-14$ & $\mathrm{~N}_{\text {excreted }}$ Intensity $\left(\Phi_{\mathrm{fi}}\right)(\mathrm{kg} / \mathrm{no}$. hatched eggs $)=\mathrm{N}_{\text {excreted }}\left(\Phi_{\mathrm{fi}}\right) /$ no. hatched eggs \\
\hline Equation FA-15 & $\mathrm{P}_{\text {excreted }}$ Intensity $\left(\Phi_{\mathrm{fi}}\right)(\mathrm{kg} / \mathrm{no}$. hatched eggs $)=\mathrm{P}_{\text {excreted }}\left(\Phi_{\mathrm{fi}}\right) /$ no. hatched eggs \\
\hline Equation FA-16 & $\mathrm{Cu}_{\text {excreted }}$ Intensity $\left(\Phi_{\mathrm{fi}}\right)(\mathrm{kg} / \mathrm{no}$. hatched eggs $)=\mathrm{Cu}_{\text {excreted }}\left(\Phi_{\mathrm{fi}}\right) /$ no. hatched eggs \\
\hline Equation FA-17 & $\mathrm{Zn}_{\text {excreted }}$ Intensity $\left(\Phi_{\mathrm{fi}}\right)(\mathrm{kg} / \mathrm{no}$. hatched eggs $)=\mathrm{Zn}_{\text {excreted }}\left(\Phi_{\mathrm{fi}}\right) /$ no. hatched eggs \\
\hline Equation PO-18 & $\mathrm{CH}_{\text {4manure }}$ Intensity $\left(\Phi_{\mathrm{fi}}\right)(\mathrm{kg} /$ no. hatched eggs $)=\mathrm{CH}_{4 \text { manure }}\left(\Phi_{\mathrm{fi}}\right) /$ no. hatched eggs \\
\hline Equation PO-19 & $\mathrm{N}_{2} \mathrm{O}_{\text {manure }}$ Intensity $\left(\Phi_{\mathrm{fi}}\right)(\mathrm{kg} /$ no. hatched eggs $)=\mathrm{N}_{2} \mathrm{O}_{\text {manure }}\left(\Phi_{\mathrm{fi}}\right) /$ no. hatched eggs \\
\hline
\end{tabular}

In the case of a modification of the animal performance, the production of hatched eggs is modified as follows:

- no. hatched eggs $\left(\Phi_{\mathrm{he}}\right)=$ no. eggs $\left(\Phi_{\mathrm{he}}\right) \times \%$ hatched eggs $\times \Phi_{\mathrm{he}} / 100$

- no. eggs $\left(\Phi_{\mathrm{he}}\right)=\mathrm{EW} \times \Phi_{\mathrm{ep}} \times \mathrm{ENb} \times \Phi_{\mathrm{ep}}$

Hence the emission intensity is modified.

Table 54: Adaptation of equations for breeding birds (change in growth performance)

\begin{tabular}{|c|c|}
\hline & Basis for calculation \\
\hline Equation FA-2 & $\mathrm{P}_{\text {retention }}\left(\Phi_{\mathrm{he}}\right)(\mathrm{kg})=\mathrm{EW} \times \Phi_{\mathrm{he}} \times \mathrm{ENb} \times \Phi_{\mathrm{he}} \times \% \mathrm{P}$ eggs $/ 100$ \\
\hline Equation FA-4 & $\mathrm{Cu}_{\text {retention }}\left(\Phi_{\mathrm{he}}\right)(\mathrm{kg})=\mathrm{EW} \times \Phi_{\mathrm{he}} \times \mathrm{ENb} \times \Phi_{\mathrm{he}} \times \% \mathrm{Cu}$ eggs $/ 100$ \\
\hline \multirow[t]{3}{*}{ Equation FA-6 } & $\mathrm{Zn}_{\text {retention }}\left(\Phi_{\mathrm{he}}\right)(\mathrm{kg})=\mathrm{EW} \times \Phi_{\mathrm{he}} \times \mathrm{ENb} \times \Phi_{\mathrm{he}} \times \% \mathrm{Zn} \mathrm{eggs}$ \\
\hline & Calculated impacts \\
\hline & Total \\
\hline Equation PO-8 & $\mathrm{N}_{\text {excreted }}\left(\Phi_{\mathrm{he}}\right)(\mathrm{kg})=\Sigma\left(\mathrm{FI}_{\mathrm{Ph}} \times \% \mathrm{CP}_{\mathrm{Ph}} / 100\right) / 6.25 \times\left(\left(0.0182 \times \mathrm{EW} \times \Phi_{\mathrm{he}}\right) \times\left(\mathrm{ENb} \times \Phi_{\mathrm{he}}\right)\right)$ \\
\hline Equation FA-9 & $\mathrm{P}_{\text {excreted }}\left(\Phi_{\text {he }}\right)(\mathrm{kg})=\mathrm{P}_{\text {intake }}-\mathrm{P}_{\text {retention }}\left(\Phi_{\text {he }}\right)$ \\
\hline Equation FA-10 & $\mathrm{Cu}_{\text {excreted }}\left(\Phi_{\mathrm{he}}\right)(\mathrm{kg})=\mathrm{Cu}_{\text {intake }}-\mathrm{Cu}_{\text {retention }}\left(\Phi_{\mathrm{he}}\right)$ \\
\hline Equation FA-11 & $\mathrm{Zn}_{\text {excreted }}\left(\Phi_{\text {he }}\right)(\mathrm{kg})=\mathrm{Zn}_{\text {intake }}-\mathrm{Zn}_{\text {retention }}\left(\Phi_{\text {he }}\right)$ \\
\hline Equation PO-13 & $\mathrm{N}_{2} \mathrm{O}_{\text {manure }}\left(\Phi_{\text {he }}\right)(\mathrm{kg})=\mathrm{N}_{\text {excreted }}\left(\Phi_{\text {he }}\right) \times \mathrm{EF}_{\text {MMS }} \times 44 / 28$ \\
\hline
\end{tabular}


Environmental performance of feed additives in livestock supply

\begin{tabular}{|c|c|}
\hline & Intensity \\
\hline Equation PO-14 & $\mathrm{N}_{\text {excreted }}$ Intensity $\left(\Phi_{\mathrm{he}}\right)(\mathrm{kg} / \mathrm{no}$. hatched eggs $)=\mathrm{N}_{\text {excreted }}\left(\Phi_{\mathrm{he}}\right) /$ no. hatched eggs $\left(\Phi_{\mathrm{he}}\right)$ \\
\hline Equation FA-15 & $\mathrm{P}_{\text {excreted }}$ Intensity $\left(\Phi_{\text {he }}\right)(\mathrm{kg} /$ no. hatched eggs $)=\mathrm{P}_{\text {excreted }}\left(\Phi_{\text {he }}\right) /$ no. hatched eggs $\left(\Phi_{\text {he }}\right)$ \\
\hline Equation FA-16 & $\mathrm{Cu}_{\text {excreted }}$ Intensity $\left(\Phi_{\mathrm{he}}\right)(\mathrm{kg} /$ no. hatched eggs $)=\mathrm{Cu}_{\text {excreted }}\left(\Phi_{\mathrm{he}}\right) /$ no. hatched eggs $\left(\Phi_{\text {he }}\right)$ \\
\hline Equation FA-17 & $\mathrm{Zn}_{\text {excreted }}$ Intensity $\left(\Phi_{\text {he }}\right)(\mathrm{kg} /$ no. hatched eggs $)=\mathrm{Zn}_{\text {excreted }}\left(\Phi_{\text {he }}\right) /$ no. hatched eggs $\left(\Phi_{\text {he }}\right)$ \\
\hline Equation PO-18 & $\mathrm{CH}_{\text {4manure }}$ Intensity $\left(\Phi_{\mathrm{he}}\right)(\mathrm{kg} / \mathrm{no}$. hatched eggs $)=\mathrm{CH}_{4 \text { manure }} /$ no. hatched eggs $\left(\Phi_{\mathrm{he}}\right)$ \\
\hline Equation PO-19 & $\mathrm{N}_{2} \mathrm{O}_{\text {manure }}$ Intensity $\left(\Phi_{\mathrm{he}}\right)(\mathrm{kg} /$ no. hatched eggs $)=\mathrm{N}_{2} \mathrm{O}_{\text {manure }}\left(\Phi_{\mathrm{he}}\right) /$ no. hatched eggs $\left(\Phi_{\mathrm{he}}\right)$ \\
\hline
\end{tabular}

When the feed additive or combination has a direct effect on methane $\left(\mathrm{CH}_{4}\right)$ or nitrous oxide $\left(\mathrm{N}_{2} \mathrm{O}\right)$ emissions, the factor $\Phi_{\mathrm{ef}}$ is used for the modification of the emission factor in the relevant equations. Although the factor is named in the same way in the equations $\left(\Phi_{\mathrm{ef}}\right)$, it will differ for the relevant emissions.

Table 55: Adaptation of equations for breeding birds (change in emission factor)

\begin{tabular}{lc} 
& \multicolumn{1}{c}{ Total } \\
\hline Equation PO-12 & $\mathrm{CH}_{4 \text { manure }}\left(\Phi_{\mathrm{ef}}\right)(\mathrm{kg})=\mathrm{VS} \times \mathrm{Bo} \times \mathrm{MCF} \times \Phi_{\mathrm{ef}} \times 0.662$ \\
\hline Equation PO-13 & $\mathrm{N}_{2} \mathrm{O}_{\text {manure }}\left(\Phi_{\mathrm{ef}}\right)(\mathrm{kg})=\mathrm{N}_{\text {excreted }} \times \mathrm{EF}_{\mathrm{MMS}} \times \Phi_{\mathrm{ef}} \times 44 / 28$ \\
\hline \multicolumn{1}{c}{ Intensity } \\
\hline Equation PO-18 & $\mathrm{CH}_{\text {4manure }}$ Intensity $\left(\Phi_{\mathrm{ef}}\right)(\mathrm{kg} / \mathrm{no}$. hatched eggs $)=\mathrm{CH}_{\text {4manure }}\left(\Phi_{\mathrm{ef}}\right) /$ no. hatched eggs \\
\hline Note: $\Phi_{\mathrm{ef}}=$ change in emission factor.
\end{tabular}

\subsection{ADDITIONAL DATA QUALITY CONSIDERATIONS}

To be regarded as suitable for LCA consideration, the effects of the additive on the nutrient level of the feed, on the feed efficiency or on the emission factors should be documented by robust state-of-the-art studies. One study is considered to be a limited level of substantiation, while a minimum of three studies could be considered a suitable level of substantiation.

Peer-reviewed publication in reputable journals is favoured. However, if reports are not published, they should be made available, including raw data for scientific evaluation by qualified independent reviewers such as regulatory bodies, academia, third parties or certification bodies. In the case that extrapolation rules are applied from one type of animal to another (species, genotype) or from one kind of farm management to another (geography, climatic conditions, feed type), they should be explicitly documented. During the evaluation of the results, the dosage of the additive should be taken into consideration and the LCA should be done on this basis. When carrying out an LCA, primary data are favoured (i.e. on-farm measurements). The number of trials is not pre-defined but it should be indicated in the LCA report to enable scientific evaluation of the results (from one trial providing assumptions to meta-analysis providing the possibility for further extrapolation). Information providing a description of the mode of action explaining the effect can be used to improve the potential extrapolation from one livestock system to another. For example: 
- Time representativeness. Data relative to the mode of action are valid without limitation; data relative to the effect envisaged should be comparable to the current situation. More recent studies have a greater weight of evidence.

- Technological representativeness. Data relative to the mode of action shall be applicable to the type of diets and type of animals concerned; data relative to zootechnical results shall be obtained for similar rations (feed formulation) and similar strains of animals (e.g. fast-growing chickens vs slow-growing chickens).

- Geographical representativeness. Data relative to the mode of action shall be extrapolated with care regarding farm management; data relative to zootechnical results should be issued from similar farming practices, and in situations in which climatic conditions are possibly affecting performance (e.g. animals raised outside of barns) the conditions of the trials should be comparable to the practice.

- Cases where primary data on production with and without additives are available. If data are available for the farm(s) part of the LCA, the results from the farms before using the additives and after using them shall be considered.

- Cases where primary data are not available. The following secondary data considerations shall be evaluated: substantiation through regulatory bodies if available, meta-analysis and literature (peer-reviewed journals, data provided by reliable research groups to ensure scientific quality).

With regard to the above-mentioned qualitative aspects of the results (representativity of the zootechnical results), one trial could be considered to provide a limited level of substantiation and three trials a consensus (already used by different regulatory instances). In the case that the mode of action is demonstrated, a scientific peer review could be sufficient and its applicability to the particular case of the LCA should be provided. The practitioner is required to use feed additives according to the specification provided by the manufacturer and under the conditions substantiated by the data (e.g. same dose, same mode of application).

In order to support public claims of performance, third-party verification is required. A third-party verifier must use a scheme with clear rules regarding data quality and communication of claims, in order to reduce the risk of misleading users of the results. This guidance document does not support comparisons between feed additive claims verified under different verification schemes. 

PART 4

Interpretation of results 



\section{Principles of interpretation}

Interpretation of the results of the study serves two purposes (EC, JRC and IES, 2010):

- First, to inform an iterative improvement of the assessment until all goals and requirements are met. At all steps of the LCA, the calculation approaches and data shall match the goals and quality requirements of the study.

- Second, to develop conclusions and recommendations, for example, in support of environmental performance improvements.

Interpretation of the results entails three main elements:

- Identification of key issues

- Characterization of uncertainty

- Recognition of limitations and recommendations

\subsection{IDENTIFICATION OF KEY ISSUES}

Identifying important issues encompasses the identification of most significant inventory data, impact categories and life cycle stages, and the sensitivity of results to methodological choices. The first step is to identify the life cycle stage processes and elementary flows that contribute most to the LCIA results, as well as the most relevant impact categories. Contribution analysis shall be conducted to quantify the relative contribution of the different stages/categories/items to the total result. Contribution analysis can be useful for various interests such as focusing on data collection or on efforts to mitigate those processes that contribute most to the LCIA results.

The second step is to establish the extent to which methodological choices such as system boundaries, cut-off criteria, data sources and allocation choices affecting the study outcomes shall be assessed, especially impact categories and life cycle stages with the most significant contributions. In addition, any explicit exclusion of supply chain activities (e.g. exclusion as a result of cut-off criteria) shall be documented in the report. Tools that should be used to assess the robustness of the footprint model include the following (EC, JRC and IES, 2010) (Table 56):

- Completeness checks. Evaluate the LCI data to confirm that they are consistent with the defined goals, scope, system boundaries and quality criteria and that the cut-off criteria have been met. These criteria include: completeness of the process (at each supply chain stage) and inclusion of the relevant processes or emissions contributing to the impact and exchanges (i.e. all significant energy or material inputs and their associated emissions have been included for each process).

- Plausibility checks. Ensure that the unit process data set results and the raw data are reasonable and, therefore, acceptable. Plausibility is part of the overall quality criteria; based on the practitioner's previous experience and existing knowledge, if unusual or surprising deviations from expected or normal results are observed, such deviation should be examined for relevance.

- Sensitivity checks. Assess the extent to which the results are determined by specific methodological choices and the impact of implementing alternative, 
Table 56: Guide for decision robustness from sensitivity and uncertainty

\begin{tabular}{ccc} 
Sensitivity & Uncertainty & Robustness \\
High & High & Low \\
\hline High & Low & Intermediate \\
\hline Low & High & Intermediate \\
\hline Low & Low & High \\
\hline
\end{tabular}

defensible choices where these are identifiable. This is particularly important with respect to allocation choices. It is useful to structure sensitivity checks for each phase of the study: goal and scope definition, the LCI model and impact assessment.

- Consistency checks. Ensure that the principles, assumptions, methods and data have been applied consistently with the goal and scope throughout the study. In particular, ensure that the following are addressed:

- data quality along the life cycle of the product and across production systems;

- methodological choices (e.g. allocation methods) across production systems; and

- the application of the impact assessments steps with the goal and scope.

\subsection{CHARACTERIZATION OF UNCERTAINTY}

This section is related to data quality assessment (subsection 5.7.3). There are several sources of uncertainty in LCA (e.g. knowledge uncertainty and process uncertainty). Knowledge uncertainty reflects limits of what is known about a given datum; while process uncertainty reflects the inherent variability of processes. Knowledge uncertainty can be reduced by collecting more data, but often limits on resources restrict the breadth and depth of data acquisition. Process uncertainty can be reduced by breaking complex systems into smaller parts or aggregations, but inherent variability cannot be eliminated completely. The LCIA characterization factors used to combine and convert the large number of inventory data into impacts also introduce uncertainty into the estimation of impacts. In addition, bias may be introduced if the LCI model misses processes or does not represent the modelled system accurately.

Variation and uncertainty of data should be estimated and reported. This is important because results based on average data (e.g. the mean of several measurements from a given process at a single or at multiple facilities) or on LCIA characterization factors with known variance do not reveal the uncertainty in the reported mean value of the impact. Uncertainty may be estimated and communicated quantitatively through a sensitivity and uncertainty analysis and/or qualitatively through a discussion. Understanding the sources and magnitude of uncertainty in the results is critical for assessing robustness of decisions that may be made based on the study results. When mitigation action is proposed, knowledge of the sensitivity to and uncertainty associated with the proposed changes provide valuable information regarding decision robustness. At the very least, efforts to accurately characterize stochastic uncertainty and its impact on the robustness of decisions should focus on those supply chain stages or emissions identified as significant in the impact assessment and interpretation. Where reporting to third parties, this uncertainty analysis shall be conducted and reported. 


\subsection{RECOGNITION OF LIMITATIONS AND RECOMMENDATIONS}

\subsubsection{Monte Carlo analysis}

In a Monte Carlo analysis, LCI parameters are considered stochastic variables with specified probability distributions, quantified as probability density functions (PDF). In each iteration, the Monte Carlo analysis creates an LCA model with one particular value from the PDF of every parameter and calculates the LCA results. Following a large number of iterations, the statistical properties of the samples of LCA results are investigated. For normally distributed data, variances are typically described in terms of an average and standard deviation. Some databases, notably ECOINVENT, use a lognormal PDF to describe the uncertainty. Other distributions (e.g. triangular and uniform) may also be used based on the uncertainty assessment in specific projects. The choices of data distribution and rationale should be documented and reported. Some software tools (e.g. OpenLCA) allow the use of Monte Carlo simulations to characterize the uncertainty in the reported impacts as affected by the uncertainty in the input parameters of the analysis.

The main goal of this guidance document is to provide a standardized methodology for evaluating the environmental benefits/costs of feed additives compared to a baseline case without additives. Therefore, the approach to performing Monte Carlo analysis is crucial. Specifically, it is important for matched systems to be compared so that random variates in the two systems being compared are not selected independently. As an example, the background electricity mix for shared processes should be the same (e.g. at the mill, the mixing motor should not have a different GHG intensity for the two alternates - with and without additive). If the two alternate systems are separately constructed as linked LCI models in an LCA software platform, then the software may have an option for comparative Monte Carlo analysis. However, because the guidance document is constructed to estimate feed additive effects through the use of $\Delta \mathrm{x}$ parameters applied to the baseline equations, it may be feasible to conduct the analysis using the $\Delta \mathrm{x}$ parameters directly rather than constructing separate LCI models.

\subsubsection{Sensitivity analysis}

Choice-related uncertainties arise from a number of methodologies, including modelling principles, system boundaries, cut-off criteria, the choice of footprint impact assessment methods and other assumptions related to time, technology and geography. Unlike the LCI and characterization factors, these uncertainties are not amenable to statistical description. However, the sensitivity of the results to these choice-related uncertainties can be characterized through scenario assessments (e.g. comparing the footprint derived from different allocation choices) and/or uncertainty analysis (e.g. Monte Carlo simulations). In addition to choice-related sensitivity evaluation, the relative sensitivity of specific activities (e.g. LCI data sets) can also be evaluated by measuring the percentage change in impact arising from a known change in input parameters (Hong et al., 2010).

\subsubsection{Normalization}

According to ISO 14044:2006 (ISO, 2006b), normalization is an optional step in impact assessment. Normalization is a process in which an impact associated with the functional unit is compared against an estimate of the entire regional impacts in that category (Sleeswijk et al., 2008). For example, livestock supply chains have 
been estimated to contribute 14.5 percent of global anthropogenic GHG emissions (Gerber et al., 2013). Similar assessments can be made at regional or national scales, provided that there exists a reasonably complete inventory of all emissions in that region contributing to the impact category. However, given the intricately linked supply chains of feed additives and animal feeds, it would make more sense to perform normalization (if needed for additional insights) for the overall LCA of animal feeds incorporating feed additives instead. For more information on normalization, refer to the LEAP guidelines on animal feeds supply chains (FAO, 2016a, subsection 12.2.3). More details can be found in UNEP (2011). 


\section{References}

AFNOR. 2011. BPX-30-323-0 General principles for an environmental communication on mass market products - Part 0: General principles and methodological framework.

Al-Deseit, B. 2009. Least-cost broiler ration formulation using linear programming technique. Journal of Animal and Veterinary Advances, 8(7): 1274-1278.

Appuhamy, J.A., Strathe, A.B., Jayasundara, S., Wagner-Riddle, C., Dijkstra, J., France, J. \& Kebreab, E. 2013. Anti-methanogenic effects of monensin in dairy and beef cattle: a meta-analysis. Journal of Dairy Science, 96(8): 5161-5173.

British Standards Institution (BSI). 2011. PAS 2050:2011 Specification for the assessment of the lifecycle of greenhouse gas emissions of goods and services. London, BSI.

Chadwick, D.R. 2005. Emissions of ammonia, nitrous oxide and methane from cattle manure heaps: effect of compaction and covering. Atmospheric Environment, 39(4): 787-799.

Chadwick, D., Sommer, S., Thorman, R., Fangueiro, D., Cardenas, L., Amon, B. \& Misselbrook, T. 2011. Manure management: Implications for greenhouse gas emissions. Animal Feed Science and Technology, 166-167: 514-531.

Dijkstra, J., Bannink, A., France, J., Kebreab, E. \& van Gastelen, S. 2018. Short communication: Antimethanogenic effects of 3-nitrooxypropanol depend on supplementation dose, dietary fiber content, and cattle type. Journal of Dairy Science, 101(10): 9041-9047.

European Commission (EC), Joint Research Centre (JRC) \& Institute for Environment and Sustainability (IES). 2010. International Reference Life Cycle Data System (ILCD) handbook - General guide for life cycle assessment - Detailed guidance. Luxembourg, Publications Office of the European Union.

EC. 2013. Product Environmental Footprint (PEF) guide. Annex II to the Recommendations of the Commission on the use of common methods to measure and communicate the life cycle environmental performance of products and organizations. European Commission Joint Research Centre. Luxembourg, Publications Office of the European Union.

EC. 2018. PEFCR Feed for food producing animals. (also available at https://ec.europa.eu/environment/eussd/smgp/pdf/PEFCR_feed.pdf).

Fang, L., Li, X., Li, L., Li, S., Liao, X., Sun, J. \& Liu, Y. 2016. Co-spread of metal and antibiotic resistance within ST3-IncHI2 plasmids from E. coli isolates of food-producing animals. Scientific Reports, 6: 25312.

FAO. 2007. FAO Technical Meeting on prebiotics. FAO Technical Meeting Report. Food Quality and Standards Service. Rome. (also available at https://edisciplinas. usp.br/pluginfile.php/1800450/mod_resource/content/1/FAO\%20-\%20 Prebiotics_Tech_Meeting_Report.pdf).

FAO. 2016a. Environmental performance of animal feeds supply chains: Guidelines for assessment. Livestock Environmental Assessment and Performance (LEAP) Partnership. Rome, FAO. (also available at www.fao.org/3/a-i6433e.pdf). 
FAO. 2016b. Environmental performance of large ruminant supply chains: Guidelines for assessment. Livestock Environmental Assessment and Performance (LEAP) Partnership. Rome, FAO. (also available at www.fao.org/3/a-i6494e.pdf).

FAO. 2016c. Greenhouse gas emissions and fossil energy use from small ruminant supply chains: Guidelines for assessment. Livestock Environmental Assessment and Performance (LEAP) Partnership. Rome, FAO. (also available at www.fao.org/3/a-i6434e.pdf).

FAO. 2016d. Greenhouse gas emissions and fossil energy use from poultry supply chains: Guidelines for assessment. Livestock Environmental Assessment and Performance (LEAP) Partnership. Rome, FAO. (also available at www.fao.org/ 3/a-i6421e.pdf).

FAO. 2018a. Nutrient flows and associated environmental impacts in livestock supply chains: Guidelines for assessment (Version 1). Livestock Environmental Assessment and Performance (LEAP) Partnership. Rome, FAO. 196 pp. (also available at http://www.fao.org/3/CA1328EN/ca1328en.pdf).

FAO. 2018b. Environmental performance of pig supply chains: Guidelines for assessment. Livestock Environmental Assessment and Performance (LEAP) Partnership. Rome, FAO. (also available at www.fao.org/3/I8686EN/i8686en.pdf).

FAO.2020. Biodiversity and the livestock sector (Version 1): Guidelines for quantative assessment. Livestock Environmental Assessment and Performance (LEAP) Partnership. Rome, FAO.

FAO \& International Feed Industry Federation (IFIF). 2010. Good practices for the feed industry - Implementing the Codex Alimentarius Code of Practice on Good Animal Feeding. FAO Animal Production and Health Manual No. 9. Rome. (also available at www.fao.org/3/i1379e/i1379e.pdf).

FAO \& World Health Organization (WHO). 2004. Manual of good practices for the feed industry - The Codex code of practice on good animal feeding CAC/ $R C P$ 54. Rome. (also available at www.fao.org/3/i1379e/i1379e06.pdf).

Fava, J., Consoli, F., Denison, R., Dickson, K., Mohin, T. \& Vigon, B., eds. 1993. Conceptual framework for life-cycle impact assessment. Pensacola, FL, SETAC. $188 \mathrm{pp}$.

Food SCP RT. 2013. ENVIFOOD Protocol, Environmental assessment of food and drinkprotocol.Brussels, EuropeanFoodSustainableConsumptionandProduction Round Table, Working Group 1.

Frischknecht, R. \& Rebitzer, G. 2005. The ecoinvent database system: a comprehensive web-based LCA database. Journal of Cleaner Production, 13: 1337-1343.

Funtowicz, S.O. \& Ravetz, J.R. 1990. Uncertainty and quality in science for policy. Theory and Decision Library A. Vol. 15. Springer Netherlands.

Gerber, P.J., Steinfeld, H., Henderson, B., Mottet, A., Opio, C., Dijkman, J., Falcucci, A. \& Tempio, G. 2013. Tackling climate change through livestock: a global assessment of emissions and mitigation opportunities. Rome, FAO. (also available at www.fao.org/3/a-i3437e.pdf).

Hellmann, B., Zelles, L., Palojarvi, A. \& Bai, Q. 1997. Emission of climate-relevant trace gases and succession of microbial communities during open-windrow composting. Applied and Environmental Microbiology, 63(3): 1011-1018.

Herzog, T., Pershing, J. \& Baumert, K.A. 2005. Navigating the numbers. Greenhouse gas data and international climate policy. World Resources Institute. 
Hong, J., Shaked, S., Rosenbaum, R.K. \& Jolliet, O. 2010. Analytical uncertainty propagation in life cycle inventory and impact assessment: Application to an automobile front panel. International Journal of Life Cycle Assessment, 15: 499-510.

Hristov, A.N., Oh, J., Firkins, J.L., Dijkstra, J., Kebreab, E., Waghorn, G., Makkar, H.P.S. et al. 2013. SPECIAL TOPICS - Mitigation of methane and nitrous oxide emissions from animal operations: I. A review of enteric methane mitigation options. Journal of Animal Science, 91(11): 5045-5069.

Huijbregts, M.A.J, Norris, G., Bretz, R., Ciroth, A., Maurice, B., von Bahr, B., Weidema, B. \& de Beaufort, A.S.H. 2001. Framework for modelling data uncertainty in lifecycle inventories. InternationalJournal of Life Cycle Assessment, 6: $127-132$.

IPCC. 2014. AR5 Climate Change 2014: Impacts, adaptation, and vulnerability. In: IPCC [online]. Geneva. [Cited 26 May 2020]. https://www.ipcc.ch/report/ar5/wg2/

IPCC. 2019. 2019 refinement to the 2006 IPCC guidelines for national greenhouse gas inventories. In: IPCC [online]. Geneva. [Cited 26 May 2020]. https://www.ipcc.ch/report/2019-refinement-to-the-2006-ipcc-guidelines-fornational-greenhouse-gas-inventories/

ISO. 1999. ISO 14024:1999 Environmental labels and declarations - Type I environmental labelling - Principles and procedures. Geneva, International Organization for Standardization. $12 \mathrm{pp}$.

ISO.2000.ISO14020:2000Environmentallabelsanddeclarations-Generalprinciples. Geneva, International Organization for Standardization. 5 pp.

ISO. 2006a. ISO 14040:2006 Environmental management - Life cycle assessment Principles and framework. Geneva, International Organization for Standardization. 20 pp.

ISO. 2006b. ISO 14044:2006 Environmental management - Life cycle assessment Requirements and guidelines. Geneva, International Organization for Standardization. $46 \mathrm{pp}$.

ISO. 2006c. ISO 14025:2006 Environmental labels and declarations - Type III environmental declarations - Principles and procedures. Geneva, International Organization for Standardization. 25 pp.

ISO. 2014. ISO 14046:2014 Environmental management - Water footprint Principles, requirements and guidelines. Geneva, International Organization for Standardization. 33 pp.

ISO. 2018a. ISO 14067:2018 Greenhouse gases - Carbon footprint of products Requirements and guidelines for quantification. Geneva, International Organization for Standardization. $46 \mathrm{pp}$.

ISO.2018b. ISO 14064-1:2018 Greenhouse gases-Part 1: Specification with guidance at the organizationlevelforquantification andreporting of greenhousegasemissions and removals. Geneva, International Organization for Standardization. 47 pp.

Kinley, R.D, de Nys, R., Vucko, M.J., Machado, L. \& Tomkins, N.W. 2016. The red macroalgae Asparagopsis taxiformis is a potent natural antimethanogenic that reduces methane production during in vitro fermentation with rumen fluid. Animal Production Science, 56(3): 282-289.

Li, X., Norman, H.C., Kinley, R.D., Laurence, M., Wilmot, M., Bender, H., de Nys, R. \& Tomkins, N. 2018. Asparagopsis taxiformis decreases enteric methane production from sheep. Animal Production Science, 58(4): 681-688. 
Medardus, J.J., Molla, B.Z., Nicol, M., Morrow, W.M., Rajala-Schultz, P.J., Kazwala, R. \& Gebreyes, W.A. 2014. In-feed use of heavy metal micronutrients in U.S. swine production systems and its role in persistence of multidrug-resistant Salmonellae. Applied and Environmental Microbiology, 80(7): 2317-2325.

Monteny, G.J., Bannink, A., \& Chadwick, D. 2006. Greenhouse gas abatement strategies for animal husbandry. Agriculture, Ecosystems and Environment, 112: 163-170.

National Academies of Sciences, Engineering, and Medicine (NASEM). 2018. Improving characterization of anthropogenic methane emissions in the United States. Washington, DC, The National Academies Press.

Oenema, O., Wrage, N., Velthof, G.L., van Groeningen, J.W., Dolfing, J. \& Kuikman, P.J. 2005. Trends in global nitrous oxide emissions from animal production systems. Nutrient Cycling in Agroecosystems, 72: 51-65.

Quantis. 2019. Guidance for measuring GHG emissions from land, forests, and soils across supply chain. [online] Lausanne, Switzerland. [Cited 26 May 2020]. https://quantis-intl.com/quantis-breaks-ground-with-guidance-on-land-related-ghg-emissions/

Roque, B.M., Salwen, J.K., Kinley, R. \& Kebreab, E. 2018. Supplementation of the seaweed Asparagopsis armata reduces enteric methane yield by over $40 \%$ without compromising milk yield in dairy cattle. Journal of Dairy Science, 100 supp. 2.

Sleeswijk, A.W., van Oers, L.F., Guinée, J.B., Struijs, J. \& Huijbregts, M.A. 2008. Normalisation in product life cycle assessment: An LCA of the global and European economic systems in the year 2000. Science of the Total Environment, 390: $227-240$.

Sommer, S.G., Olesen, J.E., Petersen, S.O., Weisbjerg, M.R., Valli, L., Rohde, L. \& Béline, F. 2009. Region-specific assessment of greenhouse gas mitigation with different manure management strategies in four agroecological zones. Global Change Biology, 15: 2825-2837.

Szanto, G.L., Hamelers, H.V.M., Rulkens, W.H. \& Veeken, A.H.M. 2007. NH3, $\mathrm{N} 2 \mathrm{O}$ and $\mathrm{CH} 4$ emissions during passively aerated composting of straw-rich pig manure. Bioresource Technology, 98(14): 2659-2670.

United Nations Environment Programme (UNEP). 2011. Global guidance principles for life cycle assessment databases: A basis for greener processes and products. (also available at https://www.lifecycleinitiative.org/wp-content/uploads/2012/12/2011\%20-\%20Global\%20Guidance\%20Principles.pdf).

Van Zijderveld, S.M., Gerrits, W.J.J., Dijkstra, J., Newbold, J.R., Hulshof, R.B.A. \& Perdok, H.B. 2011. Persistency of methane mitigation by dietary nitrate supplementation in dairy cows. Journal of Dairy Science, 94(8): 4028-4038.

Weidema, B.P. \& Wesnæs, M.S. 1996. Data quality management for life cycle inventories - an example of using data quality indicators. Journal of Cleaner Production, 4(3-4): 167-174.

World Business Council for Sustainable Development (WBCSD). 2014. Life cycle metrics for chemical products. [online] Geneva. [Cited 26 May 2020]. https:// www.wbcsd.org/Projects/Chemicals/Resources/Life-Cycle-Metrics-forChemical-Products

Wiedemann, S., McGahan, E. \& Poad, G. 2012. Using life cycle assessment to quantify the environmental impact of chicken meat production. RIRDC Publication No. 12/029. Barton, ACT, Australia, Rural Industries Research and Development Corporation.

WRI \& WBCSD. 2011. Product life cycle accounting and reporting standard. 148 pp. 


\section{Glossary}

\begin{abstract}
Acidification An impact category that addresses impacts due to acidifying substances in the environment. Emissions of $\mathrm{NOx}, \mathrm{NH}_{3}$ and SOx lead to releases of hydrogen ions $(\mathrm{H}+)$ when the gases are mineralized. The protons contribute to the acidification of soils and water when they are released in areas where the buffering capacity is low, resulting in forest decline and lake acidification.
\end{abstract}

Additive scenario

The scenario where the effect of the specific feed additive or mixture of additives under evaluation is considered in the emission modelling.

\begin{abstract}
Allocation
Partitions the input or output flows of a process or a product system between the product system under study and one or more other product systems.
\end{abstract}

Amino acids

Antimicrobial resistance (AMR)

Attributional

Baseline scenario

Biogenic carbon

Carbon dioxide equivalent $\left(\mathrm{CO}_{2}\right.$ eq. $)$
Organic compounds that contain amine and carboxyl functional groups, together with a side chain specific to each amino acid.

The phenomenon whereby microorganisms - bacteria, fungi, viruses and parasites - become resistant to the antimicrobial substances that normally inhibit or kill them. While AMR can occur naturally, the pace of its spread is on the rise due to inappropriate and excessive use of antimicrobials.

Characteristic of process-based modelling intended to provide a static representation of average conditions, excluding market-mediated effects.

The livestock system used as reference for comparison with the additive scenario.

Carbon derived from biomass (ISO, 2018a, 3.1.8.2).

A unit used for comparing the radiative forcing of a greenhouse gas (GHG) to carbon dioxide (ISO, 2018b, 2.19) expressed in terms of the amount of carbon dioxide that would have an equivalent impact. The carbon dioxide equivalent value is calculated by multiplying the mass of a given GHG by its global warming potential (GWP) (see also definition of global warming potential). 
Carbon footprint The level of greenhouse gas emissions produced by a particular activity or entity or product.

Co-production A multifunctional process with the production of the various products, which cannot be independently varied, or only varied within a very narrow range.

Co-product

Cradle-to-gate

Critical review

Cut-offs

$\operatorname{Delta}(\Delta)$

Ecotoxicity

Emission factor (EF)

Emission model
Any of two or more products coming from the same unit process or product system.

The life cycle stages from the extraction or acquisition of raw materials to the point at which the product leaves a defined output point or gate.

The process intended to ensure consistency between a life cycle assessment and the principles and requirements of this guide.

Specification of the amount of material or energy flow or the level of environmental significance associated with unit processes or product system to be excluded from a study.

The ratio between the data for the baseline scenario (bs) and for the additive scenario (as) $\left(\right.$ data $_{a s} /$ data $\left._{b s}\right)$. It is then used to affect the parameter measured in the equations used for evaluating the impact of the feed additive. It is accompanied by a subscript, indicating the type of impact assessed.

The environmental impact category that addresses the toxic impacts on an ecosystem, which damage individual species and change the structure and function of the ecosystem. Ecotoxicity is a result of a variety of different toxicological mechanisms caused by the release of substances that have a direct effect on the health of the ecosystem.

The amount of emissions to land, water or air, expressed as unit emission and relative to a unit of activity (e.g. $\mathrm{kg} \mathrm{CO}_{2}$ eq. per unit input). Emission factor data are obtained from secondary data sources.

The mathematical description - with parameters and emission factors - of the relationship between the input and the emission to land, water or air. 
Emission intensity The level of emissions per unit of economic activity or product. The term is usually used in relation to the $\mathrm{CO}_{2}$ emissions of a given country, at national level relative to the gross domestic product (GDP) (Herzog, Pershing and Baumert, 2005) or with regard to specific economic outputs ( $\mathrm{kg}$ of animal-sourced product [e.g. milk, meat, egg, wool] produced). It serves as an indicator suitable to measure the "decoupling" of economic growth and GHG emissions. In analogy, emission intensity or more generally flow intensity is used here to describe the flow of reactive $\mathrm{N}(\mathrm{Nr})$ caused by the production of one unit of an economic activity; this can be a physical unit (e.g. kg of meat or milk).

Emissions

The release of substance(s) to air and discharges to water and land.

Environmental impact

Enzyme

Eutrophication

Eutrophication potential (EP)

Feed
Any change to the environment, whether adverse or beneficial, that wholly or partially results from an organization's activities, products or services (Eco-Management and Audit Scheme [EMAS] regulation).

A compound produced by living organisms and that functions as a biochemical catalyst. Some enzymes are simple proteins while others consist of a protein linked to one or more non-protein groups.

A phenomenon linked to the flow of nutrients (mainly nitrogen and phosphorus) from sewage outfalls and (fertilized) farmland that accelerates the growth of algae and other vegetation in water. The degradation of organic material consumes oxygen, resulting in oxygen deficiency and in some cases fish death.

The quantity of substances emitted into a common measure expressed as the oxygen required for the degradation of dead biomass.

Any single or multiple materials, whether processed, semiprocessed or raw, which are intended to be fed directly to food-producing animals (FAO and IFIF, 2010). In these guidelines, feed does not include feed additives. 
Feed additive

Global warming potential (GWP)

Greenhouse gases (GHGs)

Impact category

Impact category indicator

Input

Ionophore

Land use change (LUC)
Any intentionally added ingredient not normally consumed as feed by itself, whether or not it has nutritional value, which affects the characteristics of feed, animal productivity or emissions. Microorganisms, enzymes, acidity regulators, trace elements, vitamins, phytogenic substances, functional ingredients and other products fall within the scope of this definition depending on the purpose of use and method of administration - Codex Alimentarius Code of Practice on Good Animal Feeding CAC/RCP 54 (FAO and WHO, 2008).

The capacity of a greenhouse gas to influence radiative forcing, expressed in terms of a reference substance (for example $\mathrm{CO}_{2}$-equivalents units) and a specified time horizon (e.g. GWP 20, GWP 100, GWP 500 for 20, 100 and 500 years respectively). It is related to the capacity to influence changes in the global average surface-air temperature and subsequent changes in various climate parameters along with their effects such as storm intensity, rainfall intensity and frequency of flooding.

Gaseous constituents of the atmosphere, both natural and anthropogenic, that absorb and emit radiation at specific wavelengths within the spectrum of infrared radiation emitted by the Earth's surface, the atmosphere and clouds (BSI, 2011, 3.24). GHGs include carbon dioxide $\left(\mathrm{CO}_{2}\right)$, methane $\left(\mathrm{CH}_{4}\right)$, nitrous oxide $\left(\mathrm{N}_{2} \mathrm{O}\right)$, hydrofluorocarbons (HFCs), perfluorocarbons (PFCs) and sulphur hexafluoride $\left(\mathrm{SF}_{6}\right)$.

A class representing environmental issues of concern to which life cycle inventory analysis results may be assigned.

A quantifiable representation of the contribution of a product unit to the specific impact category.

A product, material or energy flow that enters a unit process.

A class of compounds, generally cyclic, having the ability to carry ions across lipid barriers of the microbial cell due to the property of cation selectivity; examples are monensin sodium, lasalocid sodium, salinomycin and nonactin.

The change in the purpose for which land is used by humans (e.g. from cropland to forest or grassland, from forest to industrial land). 
Life cycle

Life cycle assessment (LCA)

Life cycle impact assessment (LCIA)

Multifunctionality

\section{Non-starch polysaccharides (NSP)}

\section{Output}

Phytase

Phytogenic substances

Prebiotic
The consecutive and interlinked stages of a product system, from raw material acquisition or generation of natural resources to end of life, inclusive of any recycling or recovery activity.

The compilation and evaluation of inputs, outputs and potential environmental impacts of a product system throughout its life cycle.

A phase of life cycle assessment that aims at understanding and evaluating the magnitude and significance of the potential environmental impacts for a system throughout the life cycle (ISO, 2006b, 3.4). The LCIA methods used provide impact characterization factors for elementary flows to aggregate the impact to a limited number of midpoint and/or damage indicators.

The capacity of a process or facility to provide more than one function, delivering several goods and/or services ("coproducts"). The process or facility is then "multifunctional". In these situations, all inputs and emissions linked to the process or facility may be partitioned between the product of interest and the co-products in a principled manner. An enterprise-scale assessment is possible.

Components of the plant cell wall polysaccharides (e.g. xylans and beta-glucans) and lignin in feed that are not broken down by the digestive enzymes of animals.

A product, material or energy flow that leaves a unit process. Products and materials include raw materials, intermediate products, co-products and releases.

An enzyme occurring in plants, especially cereals, or produced by fermentation which catalyzes hydrolysis of phytic acid to inositol and phosphoric acid.

Substances derived from or produced by plants used as a feed additive. Similar substances might be produced by chemical synthesis or fermentation.

An undigestible substance used to induce the growth or activity of beneficial microorganisms (e.g. bacteria and fungi) in the gastrointestinal tract. Prebiotics can alter the composition of organisms in the gut microbiome. It usually confers a health benefit on the host associated with modulation of the microbiota (FAO, 2007). 
Primary data Directly measured or collected data of specific activities within a particular product's life cycle (e.g. energy use for the production of $1 \mathrm{~kg}$ of a specific feed additive in a particular production plant).

Product category A group of products that can fulfil equivalent functions.

Product Category A set of specific rules, requirements and guidelines for develRules (PCR) oping Type III environmental declarations for one or more product categories.

Probiotic

A live microorganism administered to an animal as a feed additive. Probiotic may improve the feed digestibility by breaking down feed ingredients into nutrients, produce certain vitamins necessary for the host and/or alter the composition of organisms in the gut microbiome. Microorganisms regarded as probiotics used in animal nutrition are typically bacteria of the genera Lactobacillus, Saccharomyces, Enterococcus, Bacillus and Bifidobacterium.

Protease An enzyme that digests proteins.

Raw material A primary or secondary material used to produce a product. Secondary material includes recycled material.

Secondary data Information obtained from sources other than direct measurement of the inputs/outputs (or purchases and emissions) deriving from processes included in the life cycle of the product (BSI, 2011, 3.41). Secondary data are used when primary data are not available or when it is impractical to obtain primary data. Some emissions (e.g. methane from litter management) are calculated from a model and are therefore considered secondary data.

Sensitivity analysis A systematic procedure for estimating the effects of the choices made regarding methods and data on the results of an LCA study.

System boundary A set of criteria specifying which unit processes are part of a product system.

Unit process The smallest element considered in the life cycle inventory analysis for which input and output data are quantified.

Upstream emissions The emissions associated with processes that occur in the life cycle of a product prior to the processes owned, operated or controlled by the organization undertaking the assessment. 
Appendices 



\section{Appendix 1}

\section{Examples of application of feed additives and their functions}

Appendix 1 provides some examples of feed additive groups that can have an impact on animal production and thus the environmental impact intensity of animal-sourced products. It aims not to be exhaustive but to provide the reader with a better understanding of the types of effects.

\section{MODIFICATION OF FEED COMPOSITION}

Phytase

Poultry diets are primarily formulated based on plant ingredients; over 60 percent of the total phosphorus in plants represents as phytate phosphorus, which is poorly digested by poultry (Nelson et al., 1971; Waldroup et al., 2000). The poor utilization of phytate phosphorus in feeds causes three major problems:

- environmental pollution from unabsorbed phosphorus;

- need to add inorganic phosphorus to diets; and

- reduction in rock phosphate sources (Kebreab, Hansen and Strathe, 2012).

Phytase (myo-inositol hexakisphosphate phosphohydrolase) catalyzes the stepwise removal of phosphates from phytic acid (myo-inositol hexakisphosphate or IP) or its salt phytate. The first phytase was reported in 1907 (Suzuki, Yoshimura and Takaishi, 1907). Development of commercial phytases as a feed additive was initiated by a feed mineral company in 1962 (Wodzinski and Ullah, 1996). Through to the end of the twentieth century, development was intensified with screening of microorganisms and cloning of the phytase gene and its overexpression in the native host. Nutritional equivalency values of phytases in replacing inorganic phosphorus supplementation and in improving bioavailability of calcium, iron, zinc, amino acids and energy are well documented (Selle and Ravindran, 2007; Adeola and Cowieson, 2011; Zaghari, Avazkhanllo and Ganjkhanlou, 2015). The aim of using phytase has recently shifted: from the partial release of phosphorus to the complete depletion of IP. Implementing high doses of phytase may allow for the degradation of IP6, as well as lower esters such as inositol triphosphate and inositol diphosphate (Cowieson et al., 2016; Gautier, Walk and Dilger, 2018). The IP1 ester serves as a substrate for endogenous alkaline phosphatases, and broilers are able to remove the last $\mathrm{P}$ from IP1 to produce the nutrient inositol (Zyla et al., 2004; Cowieson, Wilcock and Bedford, 2011; Walk, Santos and Bedford, 2014). Achieving the maximum degradation of phytate, in addition to minimizing the need for inorganic phosphorus, reduces phosphorus emission and the impact of poultry systems on the environment. Use of phytase in pig feed permits a 30-percent decrease in zinc emissions from animal production (EFSA, 2014). The incorporation of phytase preparation is of the order of magnitude of $100 \mathrm{mg} / \mathrm{kg}$ feed compared with the reduction of phosphate incorporation in feed of up to 1.5 percent. As a consequence, the feed formulation may be changed as the concentration of inorganic $P$ in the diet may be decreased. An LCA study described by Kebreab et al. (2016) exemplifies this possibility in diets for pigs and poultry in different regions. Table A1.1 provides an example of feed composition modification where the total phosphorus concentration in the diet was reduced by 15-22 percent, while the digestible phosphorus level remained similar. Figure A1 provides a more general example of how enzymes affect animal production. 
Table A1.1: Example of diet composition modification linked to the use of phytase in poultry feed, in Europe, United States of America and Brazil

\begin{tabular}{|c|c|c|c|c|c|c|}
\hline \multirow[b]{2}{*}{ Feed ingredients } & \multicolumn{2}{|c|}{ Europe } & \multicolumn{2}{|c|}{ United States of America } & \multicolumn{2}{|c|}{ Brazil } \\
\hline & Control & With phytase & Control & With phytase & Control & With phytase \\
\hline Wheat & 454 & 454 & & & & \\
\hline Corn & 242 & 242 & 623 & 618 & 684 & 693 \\
\hline Rapeseed meal & 18 & 18 & & & & \\
\hline Soybean meal & 223 & 223 & 221 & 238 & 271 & 270 \\
\hline Soybean oil & & & 21 & 25 & 11 & 8 \\
\hline Rapeseed oil & 20 & 20 & & & & \\
\hline Corn DDGS & & & 64 & 64 & & \\
\hline Meat meal & & & 52 & 30 & & \\
\hline Monocalcium phosphate & 11 & 7 & & & & \\
\hline Defluorinated phosphate & & & 3 & 0.2 & & \\
\hline Dicalcium phosphate & & & & & 12 & 7 \\
\hline Calcium carbonate & 18 & 22 & 5 & 12 & 8 & 8 \\
\hline Salt & 4 & 4 & 1 & 2 & 4 & 4 \\
\hline Sodium bicarbonate & 0.4 & 0.4 & & & & \\
\hline Sulphur carbonate & & & 1 & 2 & & \\
\hline Lysine & 3 & 3 & 2 & 2 & 2 & 2 \\
\hline Threonine & 0.7 & 0.6 & 0.6 & 0.6 & 0.3 & 0.2 \\
\hline Methionine & 2 & 2 & 3 & 3 & 2 & 2 \\
\hline Phytase & 0 & 0.1 & 0 & 0.2 & 0 & 0.1 \\
\hline Vitamin premix & 5 & 5 & 2 & 2 & 5 & 5 \\
\hline \multicolumn{7}{|l|}{ Nutritional composition } \\
\hline $\mathrm{CP}(\mathrm{g} / \mathrm{kg})$ & 179 & 179 & 199 & 195 & 187 & 187 \\
\hline Total P $(\mathrm{g} / \mathrm{kg})$ & 6.1 & 5.1 & 5.9 & 4.6 & 5.61 & 4.78 \\
\hline $\mathrm{ME}(\mathrm{kcal} / \mathrm{g})$ & 3082 & 3082 & 3124 & 3124 & 3047 & 3047 \\
\hline
\end{tabular}

Note: DDGS - dried distillers grains with solubles; CP - crude protein; ME - metabolizable energy.

\section{Amino acids}

Monogastric animals have specific amino acid requirements. Usually, the amino acid profile of the plant feed ingredient is different from that of the animal-sourced product (e.g. meat, eggs). For this reason, the necessary provision of essential amino acids such as methionine, lysine, tryptophane and threonine leads to formulation of feed containing a relatively high level of proteins. Excess of proteins in the diet will be excreted and leads to potential leaching or production of nitrous oxide and ammonia.

The provision of individual amino acids has allowed the improved supply of the amino acid content of the feed in order to meet the animals' requirements. Hence, the total level of protein in the diet can be reduced, leading to a reduced use of high-protein-content feed ingredients such as soybean meal or rapeseed meal.

An LCA study described by Kebreab et al. (2016) exemplifies this possibility in diets for pigs and poultry in different regions. Table A1.2 provides details of the feed composition modification. Based on the European diet, it was necessary to reduce the energy content of the diet, leading to reduced feed efficiency. 
Table A1.2 Example of diet composition modification linked to the use of amino acids in poultry feed, in Europe, United States of America and Brazil

\begin{tabular}{|c|c|c|c|c|c|c|}
\hline \multirow[b]{2}{*}{ Feed ingredients } & \multicolumn{2}{|c|}{ Europe } & \multicolumn{2}{|c|}{ United States of America } & \multicolumn{2}{|c|}{ Brazil } \\
\hline & Control & $\begin{array}{c}\text { With } \\
\text { amino acids }{ }^{1}\end{array}$ & Control & $\begin{array}{l}\text { With } \\
\text { amino acids }\end{array}$ & Control & $\begin{array}{l}\text { With } \\
\text { amino acids }\end{array}$ \\
\hline Wheat & 0 & 454 & & & & \\
\hline Corn & 392 & 242 & 554 & 623 & 497 & 684 \\
\hline Wheat bran & 28 & 0 & & & & \\
\hline Rapeseed meal & 78 & 18 & & & & \\
\hline Soybean meal & 449 & 223 & 283 & 221 & 273 & 271 \\
\hline Soybean oil & & & 33 & 21 & 0 & 11 \\
\hline Rapeseed oil & 20 & 20 & & & & \\
\hline Corn DDGS & & & 64 & 64 & & \\
\hline Corn gluten & & & & & 200 & 0 \\
\hline Meat meal & & & 52 & 52 & & \\
\hline Monocalcium phosphate & 11 & 11 & & & & \\
\hline Defluorinated phosphate & & & 3 & 3 & & \\
\hline Dicalcium phosphate & & & & & 12 & 12 \\
\hline Calcium carbonate & 18 & 18 & 5 & 5 & & 8 \\
\hline Salt & 4 & 4 & 2 & 1 & & 4 \\
\hline Sodium bicarbonate & 0.4 & 0.4 & & & & \\
\hline Sulphur carbonate & & & 2 & 1 & & \\
\hline Lysine & 0 & 3 & 0 & 2 & 0 & 2 \\
\hline Threonine & 0 & 0.7 & 0 & 0.6 & 0 & 0.3 \\
\hline Methionine & 0 & 2 & 0 & 3 & 0 & 2 \\
\hline Vitamin premix & 5 & 5 & 2 & 2 & 5 & 5 \\
\hline \multicolumn{7}{|l|}{ Nutritional composition } \\
\hline $\mathrm{CP}(\mathrm{g} / \mathrm{kg})$ & 265 & 179 & 219 & 195 & 293 & 187 \\
\hline Total P $(\mathrm{g} / \mathrm{kg})$ & 7.29 & 6.1 & 6.0 & 5.9 & 5.14 & 5.61 \\
\hline $\mathrm{ME}(\mathrm{kcal} / \mathrm{g})$ & 2831 & 3082 & 3124 & 3124 & 3047 & 3047 \\
\hline
\end{tabular}

${ }^{1}$ The amino acids used were limited to lysine, threonine and methionine.

Note: DDGS - dried distillers grains with solubles; CP - crude protein; ME - metabolizable energy.

\section{Proteases}

Protein contained in feed ingredients, essentially in plant-based feed ingredients, is only partially digested by monogastric animals, leading to increased total protein content in the diets to fulfil the animals' requirements. Excess of proteins in the diet will be excreted, leading to potential leaching or production of nitrous oxide and ammonia.

Proteases degrade protein in the digestive tract of monogastric animals, increasing the amount of digestible amino acids, hence increasing the provision of amino acids to the animal. This allows for a reduction in the concentration of proteins in the diet and a modification of its composition.

\section{Amylases}

Starch digestibility is highly variable and depends on the type and quality of the feed ingredients used. Starch is the primary source of energy for monogastric animals and therefore its digestibility is a key element of its efficiency to cover animals' requirements. 


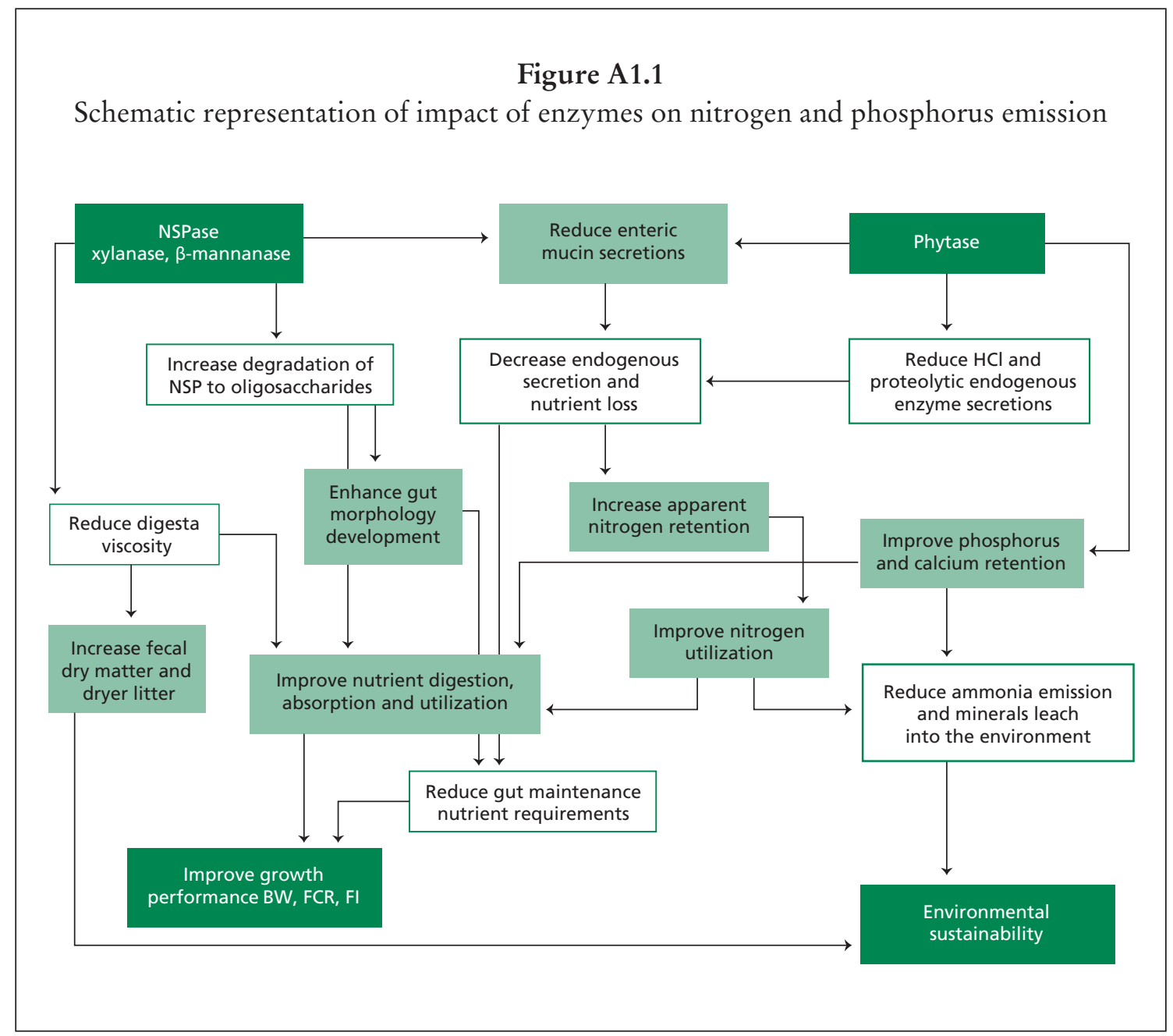

Amylases support the degradation of starch in the digestive tract of the animal, enhancing the energy value of the feed ingredients. Hence, feed ingredients with a lower starch digestibility appear more competitive than their counterparts and their incorporation in feed is modified.

\section{IMPROVED FEED EFFICIENCY}

Phytogenic substances

Phytogenic substances in ruminants' nutrition are known to improve ruminal protein metabolism, reduce enteric methane production and enhance animal performance. However, effectiveness in ruminant performance has not been proved in a consistent and conclusive manner. Phytogenic substances and their components have been shown to affect ruminal $\mathrm{N}$ metabolism in a dose-dependent manner but only in short-term in vitro experiments (Newbold et al., 2004; Busquet et al., 2006; Castillejos et al., 2008). Effects reported from in vitro studies must be interpreted with caution since they do not account for eventual shifts in microbial populates that may occur as a result of exposure of rumen microbes to phytogenic substances.

Very little in vivo research has been published testing the effect of phytogenic substances in the performance of ruminants. Observed effects on ruminants' performance include increased average daily gain (Valero et al., 2014; Yang et al., 2009; Meyer et al., 2009; Chaves et al., 2008) and feed conversion efficiency (Valero et al., 2014; Meyer et al., 2009; Benchaar, Duynisveld and Charmley, 2006). Evidence that phytogenic substances can auspiciously alter 
ruminal fermentation is based on in vitro experiments; however, type and optimization of doses requires further research. There is an urgent need to conduct long-term in vivo studies to determine the safe use of phytogenic substances in livestock nutrition and human feed production, the potential adaptation of the rumen, and possible side effects such as residues in edible products.

Wati et al. (2015) substantiated the claim that Chinese herbal feed additives exert antioxidants, enhancing immune functions and increasing antimicrobial and growth-promoting effects in livestock. Moreover, the current experimental results seem to justify the assumption that Chinese herbal feed additives may have the potential to be good candidates for promoting production performance and animal productivity.

\section{Probiotics}

The use of probiotics in small ruminant nutrition to confirm the improvement of animal health, productivity and immunity was demonstrated by El-Tawab et al. (2016). Probiotics improved growth performance by enhancing the rumen microbial ecosystem, nutrient digestibility and feed conversion rate. Moreover, probiotics have been reported to stabilize rumen $\mathrm{pH}$, increase volatile fatty acids production and stimulate lactic acid utilizing protozoa, resulting in a highly efficient rumen function.

\section{Other substances}

As evidenced by Liu et al. (2018), the possible use of prebiotics, direct-fed microbials, yeast and nucleotides may have positive impacts on pig performance, but results have been less consistent and there is a need for more research in this area.

\section{IMPROVED QUALITY OF ANIMAL PRODUCTS}

Considerable research has been conducted to evaluate potential animal performance; for example, Zawadzki et al. (2017) used extract of mate (Ilex paraguariensis A.St.-Hil.) in broiler feed to increase the oxidative stability of chicken meat, recognizing the safety and the source of a high content of alkaloids, saponins and phenolic acids. Otherwise, the addition of mate extract in the diet of feedlot cattle did not affect animal performance and carcass characteristics, but these animals presented more tender beef, well received by consumers.

\section{MODIFICATION OF EMISSION FACTORS}

Phytogenic substances may modify rumen microbiota, reduce methane emissions or increase carcass characteristics in monogastrics. The use of antibiotic growth promoters is now forbidden in many regions of the world (e.g. European Union) leaving room for natural alternatives to effectively affect feed efficiency and animal performance. This section summarizes the documented effects of the use of essential oils as feed additives in ruminants and monogastrics nutrition. It should be noted that there are more than 3000 essential oils and components available (Van de Braak and Leijten, 1999).

The inhibitory effect on methanogenesis has been extensively verified using essential oils in several in vitro experiments (Table A1.3). Effectiveness has not been proved in a consistent manner in in vivo tests. For example, in an experiment conducted by Beauchemin and McGinn (2006), steers fed for three weeks with a total mix ration containing a mixture of essential oils $(1 \mathrm{~g} /$ day $)$ showed no evidence of the effect on methanogenesis, while when sheep were fed for two weeks with a mixture of essential oils ( $0.25 \mathrm{~g} /$ day), Wang, Wang and Zhou (2009) confirmed a reduction in methane emissions. Long-term in vivo experiments are needed to confirm not only the effectiveness of essential oils to inhibit rumen methanogenesis but its persistence. 
Phytogenic substances such as tannins and saponins may have methane-mitigating potential. Tannins, as feed supplements or as tanniferous plants, have frequently been shown to have potential for reducing methane emissions by up to 20 percent (Mohammed et al., 2011; Waghorn, Tavendale and Woodfield, 2002). The reduction in methane is due to the inhibitory effect on methanogens, protozoa and other hydrogen-producing microbes (Patra and Saxena, 2010; Tavendale et al., 2005). At the same time, reduced digestibility is common for diets containing condensed tannins at high levels (Patra and Saxena, 2010; Waghorn, 2008). In addition, intake and animal health can be negatively affected if the tannin inclusion rate is more than $50 \mathrm{~g} / \mathrm{kg}$ feed (Mueller-Harvey, 2006). Temperate plants rich in tannins can replace other forages, and in hot arid regions many legumes are rich in tannins and represent a valuable feed resource. There is a wide diversity among different types of tannins depending on chemical structure, which together with level of intake partly explains differences in mitigation potential for $\mathrm{CH}_{4}$ production observed with different sources of tannins (Morgavi, Martin and Boudra, 2013; Mueller-Harvey, 2006). Tannins are also used in ruminant nutrition to increase protein utilization. This effect is obtained through tannins binding to dietary proteins, which can then become "rumen-escape" proteins that are further utilized in the intestine instead (McSweeney et al., 2001). Saponins influence $\mathrm{CH}_{4}$ production and protein metabolism in the rumen by their toxic effect on protozoa (Patra and Saxena, 2010; Jouany and Morgavi, 2007). In a meta-analysis by Goel and Makkar (2012), six of the nine studies investigated reported a decrease in $\mathrm{CH}_{4}$ production of about 6-27 percent (per unit body weight or dry matter intake [DMI]). In sheep, decreases of 10-15 percent in $\mathrm{CH}_{4}$ production have been reported with Yucca schidigera and Quillaja saponaria saponin sources (Wang, Wang and Zhou, 2009; Pen et al., 2007) and similar results have been reported for tea saponins (Mohammed et al., 2011). The effect over time is unknown and it has been observed that there may be an inactivation of rumen bacterial populations (Newbold et al., 1997), which may give a reduced effect over time.

\section{Methane inhibitors}

Inhibitors such as bromochloromethane, 2-bromo-ethane sulphonate and chloroform have been shown to reduce methane emissions, but with a harmful effect on the animal, which makes them unsuitable for use on commercial farms (McAllister and Newbold, 2008). Recently, the use of 3 -nitrooxypropanol (3NOP) was shown to reduce methane emissions in dairy cows by 30 percent without any effect on milk production or feed intake (Hristov et al., 2015). A meta-analysis conducted by Dijkstra et al. (2018) showed that 3NOP reduced enteric methane emissions by about 39 percent in dairy cattle and 22 percent in beef cattle; the authors used 11 studies reported in the literature. In contrast to the above-mentioned inhibitors, the results indicate that $3 \mathrm{NOP}$ shows no signs of toxic effects on the animal and no, or only a minor, effect on DMI. The effect

Table A1.3: Maximum methane inhibition reported using essential oils on in vitro rumen incubation

\begin{tabular}{lccc} 
Essential oil (EO) & Dosage tested & Maximum $\mathrm{CH}_{4}$ inhibition & Reference \\
Carvacrol & $1.5-5 \mathrm{mM}$ & $88.9 \%$ & Macheboeuf et al., 2008 \\
\hline Cinnamaldehyde & $1-5 \mathrm{mM}$ & $89.3 \%$ & Macheboeuf et al., 2008 \\
\hline Cinnamon oil & $250 \mathrm{mg} \mathrm{litre}{ }^{-1}$ & $70.9 \%$ & Chaves et al., 2008 \\
\hline Garlic oil & $300 \mathrm{mg} \mathrm{litre}$ & Busquet et al., 2005 \\
\hline Origanum oil & $1 \mathrm{~g} \mathrm{litre}$ & $74 \%$ & Patra and Yu 2012 \\
\hline Eucalyptus oil & $0.33-2 \mathrm{ml} \mathrm{litre}^{-1}$ & $86.9 \%$ & Sallam et al., 2009 \\
\hline Peppermint oil & $0.33-2 \mathrm{ml} \mathrm{litre}^{-1}$ & $78.6 \%$ & Agarwal et al., 2009 \\
\hline Thymol & $50-400 \mathrm{mg} \mathrm{litre}^{-1}$ & $75.6 \%$ & Evans and Martin, 2000 \\
\hline
\end{tabular}


of $3 \mathrm{NOP}$ is due to blockage of methane production by inhibition of the last step of methanogenesis (Haisan et al., 2014).

\section{Ionophores}

Ionophores are lipid-soluble ion carriers that transfer ions over the cell membrane and thus disrupt the membrane potential, specifically in grampositive bacteria, and as a consequence affect methane production (Wolin and Miller, 2006). Monensin is the most commonly applied ionophore and is routinely used in beef production and dairy cattle nutrition in North America to increase feed efficiency (Hristov et al., 2013). It promotes the production of propionate at the expense of acetate and hydrogen (Johnson and Johnson, 1995). However, the use of monensin has been shown to cause a reduction in feed intake, which may explain part of the lowering effect on methane through less feed being fermented (Hegarty, 1999; Johnson and Johnson, 1995). Monensin does not appear to have a consistent direct effect on methane production in dairy or beef cattle, but due to the increase in production, a reduction in methane emissions per unit of meat (Goodrich et al., 1984) and milk (Duffield et al., 2008) may be obtained for a short period. Ionophores are banned in the European Union for ruminants due to the potential risk of antibiotic resistance.

\section{REFERENCES}

Adeola, O. \& Cowieson, A.J. 2011. Opportunities and challenges in using exogenous enzymes to improve nonruminant animal production. Journal of Animal Science, 89: 3189-3218.

Agarwal, N., Shekhar, C., Kumar, R., Chaudhary, L.C. \& Kamra, D.N. 2009. Effect of peppermint (Mentha piperita) oil on in vitro methanogenesis and fermentation of feed with buffalo rumen liquor. Animal Feed Science and Technology, 148(2-4): 321-327.

Beauchemin, K.A. \& McGinn, S.M. 2006. Methane emissions from beef cattle: Effects of fumaric acid, essential oil, and canola oil. Journal of Animal Science, 84(6): 1489-1496.

Benchaar, C., Duynisveld, J.L. \& Charmley, E. 2006. Effects of monensin and increasing dose levels of a mixture of essential oil compounds on intake, digestion and growth performance of beef cattle. Canadian Journal of Animal Science, 86(1): 91-96.

Busquet, M., Calsamiglia, S., Ferret, A., Carro, M.D. \& Kamel, C. 2005. Effect of garlic oil and four of its compounds on rumen microbial fermentation. Journal of Dairy Science, 88(12): 4393-4404.

Busquet, M., Calsamiglia, S., Ferret, A. \& Kamel, C. 2006. Plant extracts affect in vitro rumen microbial fermentation. Journal of Dairy Science, 89(2): 761-771.

Castillejos, L., Calsamiglia, S., Martin-Tereso, J. \& Ter Wijlen, H. 2008. In vitro evaluation of effects of ten essential oils at three doses on ruminal fermentation of high concentrate feedlottype diets. Animal Feed Science and Technology, 145(1-4): 259-270.

Chaves, A.V., Stanford, K., Dugan, M.E.R., Gibson, L.L., McAllister, T.A., Van Herk, F. \& Benchaar, C. 2008. Effects of cinnamaldehyde, garlic and juniper berry essential oils on rumen fermentation, blood metabolites, growth performance, and carcass characteristics of growing lambs. Livestock Science, 117(2-3): 215-224.

Cowieson, A.J., Ruckebusch, J.P., Knap, I., Guggenbuhl, P. \& Fru-Nji, F. 2016 Phytate-free nutrition: A new paradigm in monogastric animal production. Animal Feed Science and Technology, 222: 180-189.

Cowieson, A.J., Wilcock, P. \& Bedford, M.R. 2011. Super-dosing effects of phytase in poultry and other monogastrics. World's Poultry Science Journal, 67(2): 225-236.

Dijkstra, J., Bannink, A., France, J., Kebreab, E. \& van Gastelen, S. 2018. Short communication: Antimethanogenic effects of 3-nitrooxypropanol depend on supplementation dose, dietary fiber content, and cattle type. Journal of Dairy Science, 101(10): 9041-9047. 
Duffield, T.F., Rabiee, A.R. \& Lean, I.J. 2008. A meta-analysis of the impact of monensin in lactating dairy cattle. Part 2. Production effects. Journal of Dairy Science, 91(4): 1347-1360.

European Food Safety Authority (EFSA). 2014. Scientific opinion on the potential reduction of the currently authorized maximum zinc content in complete feed. EFSA Journal, 12(5): 3668 [online]. https://www.efsa.europa.eu/en/efsajournal/pub/3668

El-Tawab, M.M.A., Youssef, I.M.I., Bakr, H.A., Fthenakis, G.C. \& Giadinis, N.D. 2016. Role of probiotics in nutrition and health of small ruminants. Polish Journal of Veterinary Sciences, 19(4): 893-906.

Evans, J.D. \& Martin, S.A. 2000. Effects of thymol on ruminal microorganisms. Current Microbiology, 41(5): 336-340.

Gautier, A.E., Walk, C.L. \& Dilger, R.N. 2018. Effects of a high level of phytase on broiler performance, bone ash, phosphorus utilization, and phytate dephosphorylation to inositol. Poultry Science, 97(1): 211-218.

Goel, G. \& Makkar, H.P. 2012. Methane mitigation from ruminants using tannins and saponins. Tropical Animal Health and Production, 44(4): 729-739.

Goodrich, R.D., Garrett, J.E., Gast, D.R., Kirick, M.A., Larson, D.A. \& Meiske, J.C. 1984. Influence of monensin on the performance of cattle. Journal of Animal Science, 58(6): 1484-1498.

Haisan, J., Sun, Y., Guan, L.L., Beauchemin, K.A., Iwaasa, A., Duval, S., Barreda, D.R. \& Oba, M. 2014. The effects of feeding 3-nitrooxypropanol on methane emissions and productivity of Holstein cows in mid lactation. Journal of Dairy Science, 97(5): 3110-3119.

Hegarty, R.S. 1999. Reducing rumen methane emissions through elimination of rumen protozoa. Australian Journal of Agricultural Research, 50(8): 1321-1328.

Hristov, A.N., Oh, J., Firkins, J.L., Dijkstra, J., Kebreab, E., Waghorn, G., Makkar, H.P.S. et al. 2013. SPECIAL TOPICS - Mitigation of methane and nitrous oxide emissions from animal operations: I. A review of enteric methane mitigation options. Journal of Animal Science, 91(11): 5045-5069.

Hristov, A.N., Oh, J., Giallongo, F., Frederick, T.W., Harper, M.T., Weeks, H.L., Branco, A.F. et al. 2015. An inhibitor persistently decreased enteric methane emission from dairy cows with no negative effect on milk production. Proceedings of the National Academy of Sciences, 112(34): 10663-10668.

Johnson, K.A. \& Johnson, D.E. 1995. Methane emissions from cattle. Journal of Animal Science, 73(8): 2483-2492.

Jouany, J.P. \& Morgavi, D.P. 2007. Use of 'natural' products as alternatives to antibiotic feed additives in ruminant production. Animal, 1(10): 1443-1466.

Kebreab, E., Liedke, A., Caro, D., Deimling, S., Binder, M. \& Finkbeiner, M. 2016. Environmental impact of using specialty feed ingredients in swine and poultry production: A life cycle assessment. Journal of Animal Science, 94(6): 2664-2681.

Kebreab, E., Hansen, A.V. \& Strathe, A.B. 2012. Animal production for efficient phosphate utilization: from optimized feed to high efficiency livestock. Current Opinion in Biotechnology, 23(6).

Liu, Y., Espinosa, C.D., Abelilla, J.J., Casas, G.A., Lagos, L.V., Lee, S.A., Kwon, W.B. et al. 2018. Non-antibiotic feed additives in diets for pigs: A review. Animal Nutrition, 4(2): 113-125.

Macheboeuf, D., Morgavi, D.P., Papon, Y., Mousset, J.L. \& Arturo-Schaan, M. 2008. Dose-response effects of essential oils on in vitro fermentation activity of the rumen microbial population. Animal Feed Science and Technology, 145(1-4): 335-350. 
McAllister, T.A. \& Newbold, C.J. 2008. Redirecting rumen fermentation to reduce methanogenesis. Australian Journal of Experimental Agriculture, 48(2): 7-13.

Meyer, N.F., Erickson, G.E., Klopfenstein, T.J., Greenquist, M.A., Luebbe, M.K., Williams, P. \& Engstrom, M.A. 2009. Effect of essential oils, tylosin, and monensin on finishing steer performance, carcass characteristics, liver abscesses, ruminal fermentation, and digestibility. Journal of Animal Science, 87(7): 2346-2354.

McSweeney, C.S., Palmer, B., McNeil, D.M. \& Krause, D.O. 2001. Microbial interactions with tannins: Nutritional consequences for ruminants. Animal Feed Science and Technology, 91(1-2): 83-93.

Mohammed, R., Zhou, M., Koenig, K.M., Beauchemin, K.A. \& Guan, L.L. 2011. Evaluation of rumen methanogen diversity in cattle fed diets containing dry corn distillers grains and condensed tannins using PCR-DGGE and qRT-PCR analyses. Animal Feed Science and Technology, 166-167: 122-131.

Morgavi, D.P., Martin, C. \& Boudra, H. 2013. Fungal secondary metabolites from Monascus spp. reduce rumen methane production in vitro and in vivo. Journal of Animal Science, 91(2): 848-860.

Mueller-Harvey, I. 2006. Unravelling the conundrum of tannins in animal nutrition and health. Journal of the Science of Food and Agriculture, 86(13): 2010-2037.

Nelson, T.S., Shieh, T.R., Wodzinski, R.J. \& Ware, J.H. 1971. Effect of supplemental phytase on the utilization of phytate phosphorus by chicks. Journal of Nutrition, 101(10): 1289-1293.

Newbold, C.J., El Hassan, S.M., Wang, J., Ortega, M.E. \& Wallace, R.J. 1997. Influence of foliage from African multipurpose trees on activity of rumen protozoa and bacteria. British Journal of Nutrition, 78(2): 237-249.

Newbold, C.J., McIntosh, F.M., Williams, P., Losa, R. \& Wallace, R.J. 2004. Effects of a specific blend of essential oil compounds on rumen fermentation. Animal Feed Science and Technology, 114(1-4): 105-112.

Patra, A.K. \& Saxena, J. 2010. A new perspective on the use of plant secondary metabolites to inhibit methanogenesis in the rumen. Phytochemistry, 71(11-12): 1198-1222.

Patra, A.K. \& Yu, Z. 2012. Effects of essential oils on methane production and fermentation by, and abundance and diversity of, rumen microbial populations. Applied and Environmental Microbiology, 78(12): 4271-4280.

Pen, B., Takaura, K., Yamaguchi, S., Asa, R. \& Takahashi, J. 2007. Effects of Yucca shidigera and Quillaja saponaria with or without $\beta$ 1-4 galacto-oligosaccharides on ruminal fermentation, methane production and nitrogen utilization in sheep. Animal Feed Science and Technology, 138(1): 75-88.

Sallam, S.M.A., Bueno, I.C.S., Brigide, P., Godoy, P.B., Vitti, D.M.S.S. \& Abdalla, A.L. 2009. Efficacy of eucalyptus oil on in vitro ruminal fermentation and methane production. Options Mediterraneennes, 85(85): 267-272.

Selle, P.H. \& Ravindran, V. 2007. Microbial phytase in poultry nutrition. Animal Feed Science and Technology, 135(1-2): 1-41.

Suzuki, U., Yoshimura, K. \& Takaishi, M. 1907. Ueber ein Enzyme phytase das Anhydrooxymethylen disphosphorasure spaltet. Collections of Agricultural Bulletins of Tokyo Imperial University, 7: 495-512.

Tavendale, M.H., Meagher, L.P., Pacheco, D., Walker, N., Attwood, G.T. \& Sivakumaran, S. 2005. Methane production from in vitro rumen incubations with Lotus pedunculatus and Medicago sativa, and effects of extractable condensed tannin fractions on methanogenesis. Animal Feed Science and Technology, 123-124(1): 403-419. 
Valero, M.V., Prado, R.M.D., Zawadzki, F., Eiras, C.E., Madrona, G.S. \& Prado, I.N.D. 2014. Propolis and essential oils additives in the diets improved animal performance and feed efficiency of bulls finished in feedlot. Acta Scientiarum. Animal Sciences, 36(4): 419-426.

Van de Braak, S.A.A.J. \& Leijten, G.C.J.J. 1999. Essential oils and oleoresins: A survey in the Netherlands and other major markets in the European Union. Rotterdam, CBI, Centre for the Promotion of Imports from Developing Countries. 116 pp.

Waghorn, G.C., Tavendale, M.H. \& Woodfield, D.R. 2002. Methanogenesis from forages fed to sheep. Proceedings of the New Zealand Grassland Association, 64: 167-171.

Waghorn, G. 2008. Beneficial and detrimental effects of dietary condensed tannins for sustainable sheep and goat production - Progress and challenges. Animal Feed Science and Technology, 147(1-3): 116-139.

Waldroup, P.W., Kersey, J.H., Saleh, E.A., Fritts, C.A., Yan, F., Stilborn, H.L., Crum, R.C. Jr. \& Raboy, V. 2000. Nonphytate phosphorus requirement and phosphorus excretion of broiler chicks fed diets composed of normal or high available phosphate corn with and without microbial phytase. Poultry Science, 79(10): 1451-1459.

Walk, C.L., Santos, T.T. \& Bedford, M.R. 2014. Influence of superdoses of a novel microbial phytase on growth performance, tibia ash, and gizzard phytate and inositol in young broilers. Poultry Science, 93(5): 1172-1177.

Wang, C.J., Wang, S.P. \& Zhou, H. 2009. Influences of flavomycin, ropadiar, and saponin on nutrient digestibility, rumen fermentation, and methane emission from sheep. Animal Feed Science and Technology, 148(2-4): 157-166.

Wati, T., Ghosh, T.K., Syed, B. \& Haldar, S. 2015. Comparative efficacy of a phytogenic feed additive and an antibiotic growth promoter on production performance, caecal microbial population and humoral immune response of broiler chickens inoculated with enteric pathogens. Animal Nutrition, 1(3): 213-219.

Wodzinski, R.J. \& Ullah, A.H.J. 1996. Phytase. Advances in Applied Microbiology, 42: 263-302.

Wolin, M.J. \& Miller, T.L. 2006. Control of rumen methanogenesis by inhibiting the growth and activity of methanogens with hydroxymethylglutaryl-SCoA inhibitors. International Congress Series, 1293: 131-137.

Yang, W.Z., Ametaj, B.N., Benchaar, C., He, M.L. \& Beauchemin, K.A. 2009. Cinnamaldehyde infeedlotcattle diets:Intake, growth performance, carcasscharacteristics, and blood metabolites. Journal of Animal Science, 88(3): 1082-1092.

Zaghari, M., Avazkhanllo, M. \& Ganjkhanlou, M. 2015. Reevaluation of male broiler zinc requirement by dose-response trial using practical diet with added exogenous phytase. Journal of Agricultural Science and Technology, 17(2): 333-343.

Zawadzki, A., Arrivetti, L.O.R., Vidal, M.P., Catai, J.R., Nassu, R.T., Tullio, R.R., Berndt, A. et al. 2017. Mate extract as feed additive for improvement of beef quality. Food Research International, 99: 336-347.

Zyla, K., Mika, M., Stodolak, B., Wikiera, A., Koreleski, J. \& Swiatkiewicz, S. 2004. Towards complete dephosphorylation and total conversion of phytates inpoultry feeds. Poultry Science, 83(7): 1175-1186. 


\section{Appendix 2}

\section{Case studies}

The objective of this appendix is to clarify and explain how to use the guidelines for different needs, considering that the guidelines are based on comparison between a baseline scenario and a scenario using a specific feed additive or feed additive mixture.

\section{CASE STUDY 1: MODIFICATION OF FEED COMPOSITION TO REDUCE THE ENVIRONMENTAL IMPACT OF POULTRY MEAT \\ Background}

A feed miller in Germany produces a feed mainly composed of corn (imported from Spain) and soybean meal (imported from Brazil). The feed is used by a poultry farm (broilers) within an integrated organization. The management of the integrated organization wishes to publicize the improved environmental footprint of the poultry meat he produces by modifying the feed formulation using more locally produced feed ingredients and with the help of feed additives.

Before changing the feed formulation, he needs to evaluate the actual impact of this change on the environmental performance of his farms.

\section{Baseline scenario}

Table A2.1 describes the feed formulation based on corn and soybean meal. The feed ingredients used and the nutritional characteristics of the feeds (starter feed from day 1 to day 21 and then grower feed from day 22 to day 42).

Table A2.1: Initial feed composition and nutritional characteristics of the feed

\begin{tabular}{lcc} 
Ingredients & Starter feed & \\
Composition $(\mathrm{g} / \mathrm{kg})$ & & 588 \\
\hline Corn & 535 & 315 \\
\hline Soybean meal & 355 & 36.3 \\
\hline Fish meal & 39.9 & 30.2 \\
\hline Vegetable oil & 35.2 & 12.7 \\
\hline Limestone & 15.2 & 3.0 \\
\hline Salt & 3.0 & 7.8 \\
\hline Monocalcium phosphate & 9.2 & 2.0 \\
\hline Vitamin premix & 2.0 & 2.0 \\
\hline Mineral premix & 2.0 & 1.0 \\
\hline DL-methionine & 1.5 & 0.6 \\
\hline L-lysine & 1.0 & 0.5 \\
\hline Choline chloride & 0.5 & 12.8 \\
\hline Calculated chemical composition (per kg wet weight) & 12.9 & 88.7 \\
\hline Metabolizable energy (MJ) & 88.9 & 206 \\
\hline Dry matter (g) & 222 & 9.5 \\
\hline Crude protein (g) & 11.2 & 7.6 \\
\hline Lysine (g) & 8.5 & 8.7 \\
\hline Methionine + Cystine (g) & 10.2 & 6.9 \\
\hline Calcium (g) & 6.9 & \\
\hline Total phosphorus (g) & & \\
\hline & & \\
\hline
\end{tabular}


Based on this composition, Table A2.2 describes the expected animal performance of the poultry in the organization.

Table A2.2: Expected poultry performance in the organization

\begin{tabular}{lc} 
Poultry performance index & Performance \\
Final body weight $(\mathrm{g})$ & 2480 \\
\hline Daily weight gain (g/day) & 56 \\
\hline Total feed consumption & 5431 \\
\hline Feed conversion rate & 2.19 \\
\hline Mortality $(\%)$ & 2 \\
\hline
\end{tabular}

Evaluated scenario

The feed miller wishes to replace partially imported corn and soybean meal with locally produced wheat, barley, rapeseed and sunflower. In order to maintain the nutritional characteristics of the feed, the feed miller will incorporate a mixture of endo-1,3-beta-xylanase and endo-1,3beta-glucanase to increase the digestibility and the energy value of wheat and barley. In addition, the miller will incorporate additional amino acids to compensate the altered amino acid balance resulting from the feed ingredients used, as well as a serine protease to increase the protein digestibility of the protein-based feed ingredients (i.e. rapeseed meal and sunflower meal).

It is assumed that by keeping the amino acids balance and maintaining the same level of crude protein and energy in the diet, the performance of the poultry will remain unchanged.

To evaluate the impact of this scenario on the environmental footprint of $1 \mathrm{~kg}$ of poultry live weight, the feed miller will follow the steps below:

- Step 1: Collect data on the environmental footprint of the new feed ingredients used in line with the LEAP guidelines on the environmental footprint of feed (FAO, 2016a).

- Step 2: Collect data on the environmental footprint of:

- the enzyme (endo-1,3-beta-xylanase, endo-1,3-beta-glucanase, serine protease) preparations used (see subsection 4.1.2 [iv] for the fermentation process and subsection 4.1.3 for the production of the preparation);

- the amino acids produced by fermentation (e.g. lysine, threonine) (see subsection 4.1.2 [iv] for the fermentation process); and

- the amino acids produced by chemical synthesis (e.g. methionine) (see subsection 4.1.2 [iii] for the chemical process).

- Step 3: Calculate the environmental footprint of the formulated feed in line with the LEAP guidelines on the environmental footprint of feed (FAO, 2016a).

- Step 4: Calculate the difference induced by the change of formulation:

- Feed conversion rate $\times$ (Environmental impact of the newly formulated feed Environmental impact of the initial formulated feed $)=($ Environmental footprint of $1 \mathrm{~kg}$ poultry live weight with the newly formulated feed - Environmental footprint of $1 \mathrm{~kg}$ poultry live weight with the initial formulated feed)

Example: if the global warming potential (including land use change) (LUC-GWP) of the new formulation is reduced by 5 percent, the LUC-GWP reduction linked to the modification of the feed composition is calculated as follows for $1 \mathrm{~kg}$ of poultry live weight:

$2.19 \times(0.95 \times$ LUC-GWP initial feed $-1.00 \times$ LUC-GWP initial feed $)=-0.1095 \times$ LUC-GWP initial feed $=$ LUC-GWP new feed formulation

Considering that feed represents 70 percent of the environmental footprint of $1 \mathrm{~kg}$ of poultry live weight, i.e. 
LUC-GWP $1 \mathrm{~kg}$ poultry live weight = LUC-GWP feed/0.7

the reduction of the LUC-GWP of $1 \mathrm{~kg}$ poultry live weight linked to the modification of the feed formulation will be $0.7 \times-0.1095=-0.07665$ (i.e. $7.7 \%$ reduction).

Sensitivity analysis

It is advised - unless there is sufficient evidence that the animal performance would remain unchanged - to organize for a sensitivity analysis which considers the change in animal performance linked to the new formulation.

For example, assuming that the new feed formulation has an impact on animal performance such as the feed conversion ratio (5\% increase), the new animal performance data are modified as indicated in Table A2.3.

Table A2.3: Expected poultry performance in the organization

\begin{tabular}{lccc} 
Poultry performance index & Initial performance & New performance & Variation (D) \\
Final body weight $(\mathrm{g})$ & 2480 & 2480 & $0 \%$ \\
\hline Daily weight gain (g/day) & 56 & 56 & $0 \%$ \\
\hline Total feed consumption & 5431 & 5702 & $+5 \%$ \\
\hline Feed conversion rate & 2.19 & 2.30 & $+5 \%$ \\
\hline Mortality $(\%)$ & 2 & 2 & $0 \%$ \\
\hline
\end{tabular}

In case study 1 , the impact of the new feed formulation is calculated as described in subsection 6.10.4 and the equations of Table 37 (Table A2.4)

Table A2.4: Evaluation of the variation in emissions and environmental impacts

\begin{tabular}{|c|c|}
\hline & Basis for calculation \\
\hline \multirow[t]{3}{*}{ Equation FA-1 } & $\mathrm{P}_{\text {intake }}\left(\Phi_{\mathrm{fi}}\right)=\Sigma\left(\mathrm{FI}_{\mathrm{Ph}} \times \Phi_{\mathrm{fi}} \times \% \mathrm{P}_{\text {totalPh }}\right) / 100$ \\
\hline & Initial: $P_{\text {intake }}\left(\Phi_{\mathrm{fi}}\right)=(2.650 \mathrm{~kg} \times 0.70+2.781 \mathrm{~kg} \times 0.66) / 100=0.037 \mathrm{~kg}$ \\
\hline & New: $P_{\text {intake }}\left(\Phi_{\text {fi }}\right)=(2.650 \mathrm{~kg} \times 1.05 \times 0.70+2.781 \times 1.05 \times 0.66) / 100=0.039 \mathrm{~kg}$ \\
\hline \multirow[t]{3}{*}{ Equation FA-3 } & $\mathrm{Cu}_{\text {intake }}\left(\Phi_{\mathrm{fi}}\right)=\Sigma\left(\mathrm{FI} \times \Phi_{\mathrm{fi}} \times \% \mathrm{Cu}_{\mathrm{Ph}}\right) / 100$ \\
\hline & Initial: $\mathrm{Cu}_{\text {intake }}\left(\Phi_{\mathrm{fi}}\right)=(2.650 \mathrm{~kg} \times 0.0025+2.781 \mathrm{~kg} \times 0.0020) / 100=0.000122 \mathrm{~kg}$ \\
\hline & New: $\operatorname{Cu}_{\text {intake }}\left(\Phi_{\text {fi }}\right)=(2.650 \mathrm{~kg} \times 1.05 \times 0.0025+2.781 \times 1.05 \times 0.0020) / 100=0.000128 \mathrm{~kg}$ \\
\hline \multirow[t]{3}{*}{ Equation FA-5 } & $\mathrm{Zn}_{\text {intake }}\left(\Phi_{\mathrm{fi}}\right)=\Sigma\left(\mathrm{FI} \times \Phi_{\mathrm{fi}} \times \% \mathrm{Zn}_{\mathrm{Ph}}\right) / 100$ \\
\hline & Initial: $\mathrm{Zn}_{\text {intake }}\left(\Phi_{\mathrm{fi}}\right)=(2.650 \mathrm{~kg} \times 0.0120+2.781 \mathrm{~kg} \times 0.0105) / 100=0.00061 \mathrm{~kg}$ \\
\hline & New: $\mathrm{Zn}_{\text {intake }}\left(\Phi_{\mathrm{fi}}\right)=(2.650 \mathrm{~kg} \times 1.05 \times 0.0120+2.781 \times 1.05 \times 0.0105) / 100=0.000641 \mathrm{~kg}$ \\
\hline \multirow[t]{5}{*}{ Equation PO-7 } & $\operatorname{VS}\left(\Phi_{\mathrm{fi}}\right)=\Sigma\left(\mathrm{FI}_{\mathrm{d}} \times \Phi_{\mathrm{fi}} \times(1-\mathrm{DMD}) \times(1-\mathrm{A})\right)$ \\
\hline & Initial: $\mathrm{VS}\left(\Phi_{\mathrm{fi}}\right)=5.431 \times(1-0.8) \times(1-0.1)=0.978 \mathrm{~kg}$ \\
\hline & New: VS $\left(\Phi_{\mathrm{fi}}\right)=5.431 \times 1.05 \times(1-0.8) \times(1-0.1)=1.026 \mathrm{~kg}$ \\
\hline & Calculated impacts \\
\hline & Total \\
\hline \multirow[t]{3}{*}{ Equation PO-8 } & $\mathrm{N}_{\text {excreted }}\left(\Phi_{\mathrm{fi}}\right)(\mathrm{kg})=\Sigma\left(\mathrm{FI}_{\mathrm{Ph}} \times \Phi_{\mathrm{fi}} \times \% \mathrm{CP}_{\mathrm{Ph}} / 100\right) / 6.25 \times(1-0.602)$ \\
\hline & Initial: $\mathrm{N}_{\text {excreted }}\left(\Phi_{\mathrm{fi}}\right)=((2.650 \times 23 / 100)+(2.781 \times 21.4 / 100)) / 6.25 \times(1-0.602)=0.0767 \mathrm{~kg}$ \\
\hline & $\begin{array}{c}\text { New: } \mathrm{N}_{\text {excreted }}\left(\Phi_{\mathrm{fi}}\right)=((2.650 \times 1.05 \times 21.4 / 100)+(2.781 \times 1.05 \times 19.9 / 100)) / 6.25 \times(1-0.602)= \\
0.749 \mathrm{~kg}\end{array}$ \\
\hline \multirow[t]{3}{*}{ Equation FA-9 } & $\mathrm{P}_{\text {excreted }}\left(\Phi_{\mathrm{fi}}\right)(\mathrm{kg})=\mathrm{P}_{\text {intake }}\left(\Phi_{\mathrm{fi}}\right)-\mathrm{P}_{\text {retention }}$ \\
\hline & Initial: $P_{\text {excreted }}\left(\Phi_{\mathrm{fi}}\right)(\mathrm{kg})=0.037-2.480 \times 1.0 / 100=0.012 \mathrm{~kg}$ \\
\hline & New: $P_{\text {excreted }}\left(\Phi_{\mathrm{fi}}\right)(\mathrm{kg})=0.039-2.480 \times 1.0 / 100=0.014 \mathrm{~kg}$ \\
\hline
\end{tabular}




\begin{tabular}{|c|c|}
\hline Equation FA-10 & $\begin{array}{c}\mathrm{Cu}_{\text {excreted }}\left(\Phi_{\mathrm{fi}}\right)(\mathrm{kg})=\mathrm{Cu}_{\text {intake }}-\mathrm{Cu}_{\text {product }} \\
\text { Initial: } \mathrm{Cu}_{\text {excreted }}\left(\Phi_{\mathrm{fi}}\right)(\mathrm{kg})=0.000122-2.480 \times 0.003 / 100=0.000048 \mathrm{~kg} \\
\text { New: } \mathrm{Cu}_{\text {excreted }}\left(\Phi_{\mathrm{fi}}\right)(\mathrm{kg})=0.000128-2.480 \times 0.003 / 100=0.000054 \mathrm{~kg}\end{array}$ \\
\hline Equation FA-11 & $\begin{array}{c}\mathrm{Zn}_{\text {excreted }}\left(\Phi_{\mathrm{fi}}\right)(\mathrm{kg})=\mathrm{Zn}_{\text {intake }}-\mathrm{Zn}_{\text {product }} \\
\text { Initial: } \mathrm{Zn}_{\text {excreted }}\left(\Phi_{\mathrm{fi}}\right)(\mathrm{kg})=0.00061-2.480 \times 0.015 / 100=0.000238 \mathrm{~kg} \\
\text { New: } \mathrm{Zn}_{\text {excreted }}\left(\Phi_{\mathrm{fi}}\right)(\mathrm{kg})=0.000641-2.480 \times 0.015 / 100=0.000269 \mathrm{~kg}\end{array}$ \\
\hline Equation PO-12 & $\begin{array}{c}\mathrm{CH}_{4 \text { manure }}\left(\Phi_{\mathrm{fi}}\right)(\mathrm{kg})=\mathrm{VS}\left(\Phi_{\mathrm{fi}}\right) \times \mathrm{Bo} \times \mathrm{MCF} \times 0.662 \\
\text { Initial: } \mathrm{CH}_{4 \text { manure }}\left(\Phi_{\mathrm{fi}}\right)(\mathrm{kg})=0.978 \times 0.36 \times 0.015 \times 0.662=0.00350 \mathrm{~kg} \\
\text { New: } \mathrm{CH}_{4 \text { manure }}\left(\Phi_{\mathrm{fi}}\right)(\mathrm{kg})=1.026 \times 0.36 \times 0.015 \times 0.622=0.00367 \mathrm{~kg}\end{array}$ \\
\hline Equation $\mathrm{PO}-13$ & $\begin{array}{c}\mathrm{N}_{2} \mathrm{O}_{\text {manure }}\left(\Phi_{\mathrm{fi}}\right)(\mathrm{kg})=\mathrm{N}_{\text {excreted }}\left(\Phi_{\mathrm{fi}}\right) \times \mathrm{EF}_{\text {MMS }} \times 44 / 28 \\
\text { Initial: } \mathrm{N}_{2} \mathrm{O}_{\text {manure }}\left(\Phi_{\mathrm{fi}}\right)(\mathrm{kg})=0.0767 \times 0.005 \times 44 / 28=0.00603 \mathrm{~kg} \\
\text { New: } \mathrm{N}_{2} \mathrm{O}_{\text {manure }}\left(\Phi_{\mathrm{fi}}\right)(\mathrm{kg})=0.749 \times 0.005 \times 44 / 28=0.00589 \mathrm{~kg}\end{array}$ \\
\hline & Intensity \\
\hline Equation PO-14 & $\begin{array}{c}\mathrm{N}_{\text {excreted }} \text { Intensity }\left(\Phi_{\mathrm{fi}}\right)(\mathrm{kg} / \mathrm{kg} \text { live weight })=\mathrm{N}_{\text {excreted }}\left(\Phi_{\mathrm{fi}}\right) / \mathrm{TWG} \\
\text { Initial: } \mathrm{N}_{\text {excreted }} \text { Intensity }\left(\Phi_{\mathrm{fi}}\right)(\mathrm{kg} / \mathrm{kg} \text { live weight })=0.0767 / 2.480=0.312 \\
\text { New: } \mathrm{N}_{\text {excreted }} \text { Intensity }\left(\Phi_{\mathrm{f}}\right)(\mathrm{kg} / \mathrm{kg} \text { live weight })=0.749 / 2.480=0.302\end{array}$ \\
\hline Equation FA-15 & $\begin{array}{c}P_{\text {excreted }} \text { Intensity }\left(\Phi_{\mathrm{fi}}\right)(\mathrm{kg} / \mathrm{kg} \text { live weight })=\mathrm{P}_{\text {excreted }}\left(\Phi_{\mathrm{f}}\right) / \mathrm{TWG} \\
\text { Initial: } \mathrm{P}_{\text {excreted }} \text { Intensity }\left(\Phi_{\mathrm{fi}}\right)(\mathrm{kg} / \mathrm{kg} \text { live weight })=0.012 / 2.480=0.0048 \\
\text { New: } \mathrm{P}_{\text {excreted }} \text { Intensity }\left(\Phi_{\mathrm{fi}}\right)(\mathrm{kg} / \mathrm{kg} \text { live weight })=0.014 / 2.480=0.0056\end{array}$ \\
\hline Equation FA-16 & $\begin{array}{c}\mathrm{Cu}_{\text {excreted }} \text { Intensity }\left(\Phi_{\mathrm{f}}\right)(\mathrm{kg} / \mathrm{kg} \text { live weight })=\mathrm{Cu}_{\text {excreted }}\left(\Phi_{\mathrm{f}}\right) / \mathrm{TWG} \\
\text { Initial: } \mathrm{Cu}_{\text {excreted }} \text { Intensity }\left(\Phi_{\mathrm{fi}}\right)(\mathrm{kg} / \mathrm{kg} \text { live weight })=0.000048 / 2.480=0.000019 \\
\text { New: } \mathrm{Cu}_{\text {excreted }} \text { Intensity }\left(\Phi_{\mathrm{fi}}\right)(\mathrm{kg} / \mathrm{kg} \text { live weight })=0.000054 / 2.480=0.000022\end{array}$ \\
\hline Equation FA-17 & $\begin{array}{c}\mathrm{Zn}_{\text {excreted }} \text { Intensity }\left(\Phi_{\mathrm{f}}\right)(\mathrm{kg} / \mathrm{kg} \text { live weight })=\mathrm{Zn}_{\text {excreted }}\left(\Phi_{\mathrm{f}}\right) / \mathrm{TWG} \\
\text { Initial: } \mathrm{Zn}_{\text {excreted }} \text { Intensity }\left(\Phi_{\mathrm{f}}\right)(\mathrm{kg} / \mathrm{kg} \text { live weight })=0.000238 / 2.480=0.000096 \\
\text { New: } \mathrm{Zn}_{\text {excreted }} \text { Intensity }\left(\Phi_{\mathrm{fi}}\right)(\mathrm{kg} / \mathrm{kg} \text { live weight })=0.000268 / 2.480=0.000108\end{array}$ \\
\hline Equation PO-18 & $\begin{array}{c}\mathrm{CH}_{4 \text { manure }} \text { Intensity }\left(\Phi_{\mathrm{f}}\right)(\mathrm{kg} / \mathrm{kg} \text { live weight })=\mathrm{CH}_{4 \text { manure }}\left(\Phi_{\mathrm{fi}} / \mathrm{TWG}\right. \\
\text { Initial: } \mathrm{CH}_{4 \text { manure }} \text { Intensity }\left(\Phi_{\mathrm{fi}}\right)(\mathrm{kg} / \mathrm{kg} \text { live weight })=0.00350 / 2.480=0.000141 \\
\text { New: } \mathrm{CH}_{4 \text { manure }} \text { Intensity }\left(\Phi_{\mathrm{fi}}\right)(\mathrm{kg} / \mathrm{kg} \text { live weight })=0.00367 / 2.480=0.000148\end{array}$ \\
\hline Equation PO-19 & $\begin{array}{c}\mathrm{N}_{2} \mathrm{O}_{\text {manure }} \text { Intensity }\left(\Phi_{\mathrm{fi}}\right)(\mathrm{kg} / \mathrm{kg} \text { live weight })=\mathrm{N}_{2} \mathrm{O}_{\text {manure }}\left(\Phi_{\mathrm{f}}\right) / \mathrm{TWG} \\
\text { Initial: } \mathrm{N}_{2} \mathrm{O}_{\text {manure }} \text { Intensity }\left(\Phi_{\mathrm{f}}\right)(\mathrm{kg} / \mathrm{kg} \text { live weight })=0.00603 / 2.48=0.00243 \\
\text { New: } \mathrm{N}_{2} \mathrm{O}_{\text {manure }} \text { Intensity }\left(\Phi_{\mathrm{fi}}\right)(\mathrm{kg} / \mathrm{kg} \text { live weight })=0.00589 / 2.48=0.00238\end{array}$ \\
\hline
\end{tabular}

Based on the above-mentioned assumption, the following variation will be observed:

- increased phosphorus excretion by $0.0008 \mathrm{~kg} / \mathrm{kg}$ live weight

- decreased nitrogen excretion by $0.010 \mathrm{~kg} / \mathrm{kg}$ live weight

leading to modification of the eutrophication and acidification potential; and

- increased methane production from the manure linked to increased excretion of volatile solids $(+5 \%)$

- reduced nitrous oxide production linked to reduced nitrogen excretion $(-2 \%)$

leading to modification of the global warming potential.

These effects should then be deducted from the modified environmental footprint (e.g. decreased LU-GWP) achieved with the change of formulation.

\section{Conclusion}

The net results shall inform the choice of the poultry production organization, as to whether the proposed formulation change improve the environmental footprint of $1 \mathrm{~kg}$ of poultry live weight. 


\section{CASE STUDY 2: DECREASE ENTERIC METHANE PRODUCTION FROM DAIRY COW USING A FEED ADDITIVE}

Background

A dairy cooperative wishes to reduce the environmental footprint - and more particularly the global warming potential (GWP) - of the milk it sells globally. Given that a considerable amount of the GWP originates from the cows' digestive system (enteric methane production), the dairy cooperative requests that its feed suppliers produce a feed containing a feed additive that reduces enteric methane when incorporated into the dairy cows' daily ration.

The feed millers shall then evaluate the potential reduction linked to the use of a methane inhibitor. The methane inhibitor reduces the enteric methane of dairy cows by an average of 25 percent $\left(\Phi_{\text {ef }}=0.75\right)$, with a parallel improved feed conversion ratio of 2 percent. The information relative to the methane emission is issued from a meta-analysis based on over 15 trials, while the effect of the feed conversion has been seen only in some trials and is not completely consistent.

\section{Baseline scenario}

The dairy daily ration in the region, where the methane inhibitor is to be introduced, is based on ensiled roughages (variable depending on on-farm availability) and the use of protein-rich and mineral-rich complements. The methane inhibitor is to be incorporated in the protein-rich supplement before delivery to the farms. The protein-rich supplement is then incorporated in the total dairy ration.

In the region where the study is organized, the dairy cooperative has selected farms according to performance (Table A2.5).

Table A2.5: Expected dairy cow performance for farms where the methane inhibitor will be used

\begin{tabular}{lc} 
Dairy performance index & Performance \\
Body weight $(\mathrm{kg})$ & 680 \\
\hline Annual energy-corrected milk production $(\mathrm{kg})$ & 9000 \\
\hline Total feed consumption (kg dry matter) & 7800 \\
\hline Feed conversion rate & 0.87 \\
\hline Estimated $\mathrm{CH}_{4}$ emission $(\mathrm{kg})$ & 120 \\
\hline
\end{tabular}

Evaluated scenario

The mitigation method involves incorporation in the complementary feed of the methane inhibitor (a chemically synthesized molecule) in the form of a preparation. The incorporation rate of the preparation is around $500 \mathrm{mg} / \mathrm{kg}$ dry matter in the total dairy ration. Hence, the general composition of the daily ration is not modified.

The original scenario assumes that the potential effect of the methane inhibitor will not be considered.

To evaluate the impact of the scenario on the environmental footprint of $1 \mathrm{~kg}$ of energy-corrected milk before delivery to the dairy, the feed miller will follow the steps below (Table A2.6):

- Step 1: Collect data on the environmental footprint of the methane inhibitor incorporated in the feed supplement (see subsection 4.1.2 [iii] on chemical synthesis and subsection 4.1.3 for the further preparation of the substance).

- Step 2: Add the data collected on the methane inhibitor preparation to the environmental footprint of the daily ration.

- Step 3: Calculate the impact on the global warming potential linked to the reduction of methane due to the use of the methane inhibitor. 
Table A2.6: Calculated impact of enteric methane emission reduction using a methane inhibitor in feed

\begin{tabular}{|c|c|}
\hline & Calculated impacts \\
\hline & Total \\
\hline \multirow[t]{3}{*}{ Equation LR-11 } & $\mathrm{CH}_{4 \text { enteric }}\left(\Phi_{\mathrm{ef}}\right)(\mathrm{kg})=\Sigma\left(\mathrm{GE}_{\mathrm{d}} \times \mathrm{EF} \times \Phi_{\mathrm{ef}} / 55.65\right)$ \\
\hline & Initial: $\mathrm{CH}_{4 \text { enteric }}\left(\Phi_{\mathrm{ef}}\right)(\mathrm{kg})=143910 \times 0.065 / 55.65=168 \mathrm{~kg}$ \\
\hline & New: $\mathrm{CH}_{4 \text { enteric }}\left(\Phi_{\mathrm{ef}}\right)(\mathrm{kg})=143910 \times 0.065 \times 0.75 / 55.65=126 \mathrm{~kg}$ \\
\hline \multirow[t]{3}{*}{ Equation LR-12 } & $\mathrm{CH}_{4 \text { manure }}\left(\Phi_{\mathrm{ef}}\right)(\mathrm{kg})=\Sigma\left(\mathrm{VS}_{\mathrm{d}} \times \mathrm{Bo} \times \mathrm{MCF} \times \Phi_{\mathrm{ef}} \times 0.67\right)$ \\
\hline & Initial: $\mathrm{CH}_{4 \text { manure }}\left(\Phi_{\mathrm{ef}}\right)(\mathrm{kg})=7800 \times(1.04-0.60) \times 0.36 \times 0.59 \times 0.67=488.4 \mathrm{~kg}$ \\
\hline & New: $\mathrm{CH}_{4 \text { manure }}\left(\Phi_{\mathrm{ef}}\right)(\mathrm{kg})=7800 \times(1.04-0.60) \times 0.36 \times 0.59 \times 1 \times 0.67=488.4 \mathrm{~kg}$ \\
\hline \multirow[t]{2}{*}{ Equation LR-13 } & $\mathrm{N}_{2} \mathrm{O}_{\text {manure }}\left(\Phi_{\mathrm{ef}}\right)($ refer to FAO, 2016b, Figure 14) \\
\hline & Intensity \\
\hline \multirow[t]{3}{*}{ Equation LR-16 } & $\mathrm{CH}_{4 \text { enteric }}$ Intensity $\left(\Phi_{\mathrm{ef}}\right)(\mathrm{kg} / \mathrm{kg} \mathrm{ECM})=\mathrm{CH}_{4 \text { enteric }}\left(\Phi_{\mathrm{ef}}\right) / \mathrm{ECM}$ \\
\hline & Initial: $\mathrm{CH}_{4 \text { enteric }}$ Intensity $\left(\Phi_{\mathrm{ef}}\right)(\mathrm{kg} / \mathrm{kg} \mathrm{ECM})=168 / 9000=0.0187$ \\
\hline & New: $\mathrm{CH}_{4 \text { enteric }}$ Intensity $\left(\Phi_{\mathrm{ef}}\right)(\mathrm{kg} / \mathrm{kg} \mathrm{ECM})=126 / 9000=0.0140$ \\
\hline \multirow[t]{3}{*}{ Equation LR-17 } & $\mathrm{CH}_{4 \text { manure }}$ Intensity $\left(\Phi_{\mathrm{ef}}\right)(\mathrm{kg} / \mathrm{kg} \mathrm{ECM})=\mathrm{CH}_{4 \text { manure }}\left(\Phi_{\mathrm{ef}}\right) / \mathrm{ECM}$ \\
\hline & Initial: $\mathrm{CH}_{4 \text { manure }}$ Intensity $\left(\Phi_{\mathrm{ef}}\right)(\mathrm{kg} / \mathrm{kg} \mathrm{ECM})=488.4 / 9000=0.054$ \\
\hline & New: $\mathrm{CH}_{4 \text { manure }}$ Intensity $\left(\Phi_{\mathrm{ef}}\right)(\mathrm{kg} / \mathrm{kg} \mathrm{ECM})=488.4 / 9000=0.054$ \\
\hline Equation LR-18 & $\mathrm{N}_{2} \mathrm{O}_{\text {manure }}$ Intensity $\left(\Phi_{\mathrm{ef}}\right)(\mathrm{kg} / \mathrm{kg} \mathrm{ECM})=\mathrm{N}_{2} \mathrm{O}_{\text {manure }}\left(\Phi_{\mathrm{ef}}\right) / \mathrm{ECM}$ \\
\hline
\end{tabular}

As the effect is only on enteric methane emission, the other values remain unchanged. The reduction of the GWP is linked to the 25 percent reduction in enteric methane emission.

\section{Sensitivity analysis}

As the supplier of the methane inhibitor indicates an improved feed conversion ratio of about 2 percent $\left(\mathrm{F}_{\mathrm{fi}}=0.98\right)$ linked to a reduction in the feed intake, a sensitivity analysis on the potential additional effect of the feed efficiency changes may be considered. If this is the case, the performance element provided in Table A2.7 should be used.

Table A2.7: Expected dairy cow performance for the group of farms where the methane inhibitor will be used

\begin{tabular}{lccc} 
Dairy performance index & Initial performance & New performance & Variation (D) \\
Body weight $(\mathrm{kg})$ & 680 & 680 & $0 \%$ \\
\hline Annual energy-corrected milk production $(\mathrm{kg})$ & 9000 & 9000 & $0 \%$ \\
\hline Total feed consumption $(\mathrm{kg}$ dry matter) & 7800 & 7644 & $-2 \%$ \\
\hline Feed conversion rate & 0.87 & 0.85 & $-2 \%$ \\
\hline Estimated $\mathrm{CH}_{4}$ emission $(\mathrm{kg})$ & 120 & 90 & $-25 \%$ \\
\hline
\end{tabular}

The impact of the change in feed intake will be calculated as described in subsection 6.10.4 and the equations in Table 8 (Table A2.8). 
Table A2.8: Evaluation of the variation in emissions and environmental impacts

\begin{tabular}{|c|c|}
\hline & Basis for calculation \\
\hline \multirow[t]{3}{*}{ Equation LR-1 } & $\begin{aligned} \mathrm{ME}_{\text {intakeother }}\left(\Phi_{\mathrm{fi}}\right)(\mathrm{MJ})= & \Sigma\left(\text { Total ME requirement }_{\mathrm{d}}-\left(\mathrm{DMI}_{\mathrm{d}} \times \Phi_{\mathrm{fi}} \times \mathrm{ME}_{\mathrm{t}} / \mathrm{kg} \mathrm{DM}\right)_{\text {feed } 1}\right. \\
& \left.-\left(\mathrm{DMI}_{\mathrm{d}} \times \Phi_{\mathrm{i}} \times \mathrm{ME}_{\mathrm{t}} / \mathrm{kg} \mathrm{DM}\right)_{\mathrm{feed} 2}\right)\end{aligned}$ \\
\hline & Initial: $\mathrm{ME}_{\text {intakeother }}\left(\Phi_{\mathrm{fi}}\right)(\mathrm{MJ})=67592-(1560 \times 9)=53552 \mathrm{MJ}$ \\
\hline & New: $\mathrm{ME}_{\text {intakeother }}\left(\Phi_{\mathrm{fi}}\right)(\mathrm{MJ})=67592-(1528.8 \times 9.2)=53527 \mathrm{MJ}$ \\
\hline \multirow[t]{3}{*}{ Equation LR-2 } & $\mathrm{DMI}_{\text {other }}\left(\Phi_{\mathrm{fi}}\right)(\mathrm{kg})=\mathrm{ME}_{\text {intakeother }}\left(\Phi_{\mathrm{fi}}\right) /(\mathrm{ME} / \mathrm{kg} \mathrm{DM})$ \\
\hline & Initial: $\mathrm{DMI}_{\text {other }}\left(\Phi_{\mathrm{fi}}\right)(\mathrm{kg})=53552 / 8.58=6241 \mathrm{~kg}$ \\
\hline & New: $\mathrm{DMI}_{\text {other }}\left(\Phi_{\mathrm{fi}}\right)(\mathrm{kg})=53527 / 8.75=6117 \mathrm{~kg}$ \\
\hline \multirow[t]{3}{*}{ Equation LR-3 } & $\mathrm{GE}\left(\Phi_{\mathrm{fi}}\right)(\mathrm{MJ})=\mathrm{DMI} \times \Phi_{\mathrm{fi}} \times 18.45$ \\
\hline & Initial: $\mathrm{GE}\left(\Phi_{\mathrm{fi}}\right)(\mathrm{MJ})=7800 \times 18.45=143910 \mathrm{~kg}$ \\
\hline & New: $G E\left(\Phi_{f i}\right)(M J)=7800 \times 0.98 \times 18.45=141032 \mathrm{~kg}$ \\
\hline \multirow[t]{3}{*}{ Equation LR-4a } & $\% \mathrm{~N}$ in feed $(\%)=\% \mathrm{CP} / 6.25$ \\
\hline & Initial: $\% \mathrm{~N}$ in feed $(\%)=18 / 6.25=2.88 \%$ \\
\hline & New: $\% \mathrm{~N}$ in feed $(\%)=18 / 6.25=2.88 \%$ \\
\hline \multirow[t]{3}{*}{ Equation LR-4b } & $\mathrm{N}_{\text {intake }}\left(\Phi_{\mathrm{fi}}\right)(\mathrm{kg})=\mathrm{DMI} \times \Phi_{\mathrm{fi}} \times \% \mathrm{~N}$ in feed $/ 100$ \\
\hline & Initial: $\mathrm{N}_{\text {intake }}\left(\Phi_{\mathrm{fi}}\right)(\mathrm{kg})=7800 \times 2.88 / 100=224.64 \mathrm{~kg}$ \\
\hline & New: $\mathrm{N}_{\text {intake }}\left(\Phi_{\mathrm{fi}}\right)(\mathrm{kg})=7800 \times 0.98 \times 2.88 / 100=220.15 \mathrm{~kg}$ \\
\hline \multirow[t]{3}{*}{ Equation LR-5 } & $\mathrm{P}_{\text {intake }}\left(\Phi_{\mathrm{fi}}\right)(\mathrm{kg})=\mathrm{DMI} \times \Phi_{\mathrm{fi}} \times \% \mathrm{P}_{\text {total }} / 100$ \\
\hline & Initial: $P_{\text {intake }}\left(\Phi_{\mathrm{fi}}\right)(\mathrm{kg})=7800 \times 0.3 / 100=23.4 \mathrm{~kg}$ \\
\hline & New: $P_{\text {intake }}\left(\Phi_{\text {fi }}\right)(\mathrm{kg})=7800 \times 0.98 \times 0.3 / 100=22.9 \mathrm{~kg}$ \\
\hline \multirow[t]{5}{*}{ Equation LR-8 } & $\operatorname{VS}\left(\Phi_{\mathrm{fi}}\right)(\mathrm{kg} /$ day $)=\mathrm{DMI} \times \Phi_{\mathrm{fi}} \times(1.04-\mathrm{DMD}) \times 0.92$ \\
\hline & Initial: $\operatorname{VS}\left(\Phi_{\mathrm{fi}}\right)(\mathrm{kg} /$ day $)=21.36 \times(1.04-0.75) \times 0.92=5.70 \mathrm{~kg} /$ day \\
\hline & New: $\operatorname{VS}\left(\Phi_{\text {fi }}\right)(\mathrm{kg} /$ day $)=21.36 \times 0.98(1.04-0.75) \times 0.92=5.58 \mathrm{~kg} /$ day \\
\hline & Calculated impacts \\
\hline & Total \\
\hline \multirow[t]{3}{*}{ Equation LR-9 } & $\mathrm{N}_{\text {excreted }}\left(\Phi_{\mathrm{f}}\right)(\mathrm{kg})=\mathrm{N}_{\text {intake }}\left(\Phi_{\mathrm{fi}}\right)-\mathrm{N}_{\text {product }}$ \\
\hline & Initial: $\mathrm{N}_{\text {excreted }}\left(\Phi_{\mathrm{f}}\right)(\mathrm{kg})=224.64-9000 \times 3.2 / 100 / 6.38=45.1 \mathrm{~kg}$ \\
\hline & New: $\mathrm{N}_{\text {excreted }}\left(\Phi_{\mathrm{fi}}\right)(\mathrm{kg})=220.15-9000 \times 3.2 / 100 / 6.38=40.6 \mathrm{~kg}$ \\
\hline \multirow[t]{3}{*}{ Equation LR-10 } & $\mathrm{P}_{\text {excreted }}\left(\Phi_{\mathrm{fi}}\right)(\mathrm{kg})=\mathrm{P}_{\text {intake }}\left(\Phi_{\mathrm{fi}}\right)-\mathrm{P}_{\text {product }}$ \\
\hline & Initial: $P_{\text {excreted }}\left(\Phi_{\mathrm{fi}}\right)(\mathrm{kg})=23.4 \times 9000 \times 0.1 / 100=14.4 \mathrm{~kg}$ \\
\hline & New: $P_{\text {excreted }}\left(\Phi_{\mathrm{fi}}\right)(\mathrm{kg})=22.9 \times 9000 \times 0.1 / 100=13.9 \mathrm{~kg}$ \\
\hline \multirow[t]{3}{*}{ Equation LR-11 } & $\mathrm{CH}_{4 \text { enteric }}\left(\Phi_{\mathrm{fi}}\right)(\mathrm{kg})=\mathrm{GE}\left(\Phi_{\mathrm{fi}}\right) \times \mathrm{EF} / 55.65$ \\
\hline & Initial: $\mathrm{CH}_{4 \text { enteric }}\left(\Phi_{\mathrm{fi}}\right)(\mathrm{kg})=143910 \times 0.065 / 55.65=168 \mathrm{~kg}$ \\
\hline & New: $\mathrm{CH}_{4 \text { enteric }}\left(\Phi_{\mathrm{fi}}\right)(\mathrm{kg})=141032 \times 0.065 / 55.65=165 \mathrm{~kg}$ \\
\hline \multirow[t]{3}{*}{ Equation LR-12 } & $\mathrm{CH}_{4 \text { manure }}\left(\Phi_{\mathrm{fi}}\right)(\mathrm{kg})=\Sigma\left(\mathrm{VS}_{\mathrm{d}}\left(\Phi_{\mathrm{fi}}\right) \times \mathrm{Bo} \times \mathrm{MCF}_{\mathrm{d}}\right) \times 0.67$ \\
\hline & Initial: $\mathrm{CH}_{4 \text { manure }}\left(\Phi_{\mathrm{fi}}\right)(\mathrm{kg})=5.70 \times 365 \times 0.36 \times 0.59 \times 0.67=296.1 \mathrm{~kg}$ \\
\hline & New: $\mathrm{CH}_{4 \text { manure }}\left(\Phi_{\mathrm{fi}}\right)(\mathrm{kg})=5.58 \times 365 \times 0.36 \times 0.59 \times 0.67=289.8 \mathrm{~kg}$ \\
\hline \multirow[t]{2}{*}{ Equation LR-13 } & $\mathrm{N}_{2} \mathrm{O}_{\text {manure }}\left(\Phi_{\text {fi }}\right)($ see FAO, 2016b, Figure 14) \\
\hline & Intensity \\
\hline \multirow[t]{3}{*}{ Equation LR-14 } & $\mathrm{N}_{\text {excreted }}$ Intensity $(\mathrm{kg} / \mathrm{kg} \mathrm{ECM})=\mathrm{N}_{\text {excreted }}\left(\Phi_{\mathrm{fi}}\right) / \mathrm{ECM}$ \\
\hline & Initial: $\mathrm{N}_{\text {excreted }}$ Intensity $(\mathrm{kg} / \mathrm{kg} \mathrm{ECM})=45.1 / 9000=0.005$ \\
\hline & New: $\mathrm{N}_{\text {excreted }}$ Intensity $(\mathrm{kg} / \mathrm{kg} \mathrm{ECM})=40.6 / 9000=0.0045$ \\
\hline \multirow[t]{3}{*}{ Equation LR-15 } & $\mathrm{P}_{\text {excreted }}$ Intensity $(\mathrm{kg} / \mathrm{kg} \mathrm{ECM})=\mathrm{P}_{\text {excreted }}\left(\Phi_{\mathrm{f}}\right) / \mathrm{ECM}$ \\
\hline & Initial: $P_{\text {excreted }}$ Intensity $(\mathrm{kg} / \mathrm{kg} \mathrm{ECM})=14.4 / 9000=0.0016$ \\
\hline & New: $P_{\text {excreted }}$ Intensity $(\mathrm{kg} / \mathrm{kg}$ ECM $)=13.9 / 9000=0.00154$ \\
\hline
\end{tabular}




\begin{tabular}{lc}
\hline Equation LR-16 & $\mathrm{CH}_{\text {4enteric }}$ Intensity $(\mathrm{kg} / \mathrm{kg} \mathrm{ECM})=\mathrm{CH}_{4 \text { enteric }}\left(\Phi_{\mathrm{fi}}\right) / \mathrm{ECM}$ \\
& $\begin{array}{l}\text { Initial: } \mathrm{CH}_{\text {4enteric }} \text { Intensity }(\mathrm{kg} / \mathrm{kg} \mathrm{ECM})=168 / 9000=0.0187 \\
\mathrm{New}: \mathrm{CH}_{4 \text { enteric }} \text { Intensity }(\mathrm{kg} / \mathrm{kg} \mathrm{ECM})=165 / 9000=0.0183\end{array}$ \\
\hline Equation LR-17 & $\mathrm{CH}_{4 \text { manure }}$ Intensity $(\mathrm{kg} / \mathrm{kg} \mathrm{ECM})=\mathrm{CH}_{4 \text { manure }}\left(\Phi_{\mathrm{fi}}\right) / \mathrm{ECM}$ \\
& Initial: $\mathrm{CH}_{4 \text { manure }}$ Intensity $(\mathrm{kg} / \mathrm{kg} \mathrm{ECM})=296.1 / 9000=0.0329$ \\
& $\mathrm{New}: \mathrm{CH}_{4 \text { manure }}$ Intensity $(\mathrm{kg} / \mathrm{kg} \mathrm{ECM})=289.8 / 9000=0.0322$ \\
\hline Equation LR-18 & $\mathrm{N}_{2} \mathrm{O}_{\text {manure }}$ Intensity $(\mathrm{kg} / \mathrm{kg} \mathrm{ECM})=\mathrm{N}_{2} \mathrm{O}_{\text {manure }}\left(\Phi_{\mathrm{fi}}\right) / \mathrm{ECM}$ \\
\hline
\end{tabular}

Based on the above-mentioned assumption, the following variation will be observed:

- decreased phosphorus excretion by $0.00006 \mathrm{~kg} / \mathrm{kg}$ energy-corrected milk

- decreased nitrogen excretion by $0.0005 \mathrm{~kg} / \mathrm{kg}$ energy-corrected milk leading to potential decreased eutrophication and acidification potential; and

- decreased methane production from the manure linked to decreased excretion of volatile solids $(-2.1 \%)$

- decreased nitrous oxide production linked to decreased nitrogen excretion $(-2 \%)$

leading to a small additional effect on GWP.

These effects should then be added to the modified environmental footprint (e.g. decreased LU-GWP) achieved with the effect on enteric methane only. In both cases, the effect of the production of the additive should be included.

\section{Conclusion}

The net results shall then inform the choice of the dairy production organization, as to whether the proposed addition of this methane inhibitor in the dairy's daily ration improves the environmental footprint of $1 \mathrm{~kg}$ of energy-corrected milk at the desired order of magnitude. 


\section{CASE STUDY 3: MODIFICATION OF PERFORMANCE FOR REDUCING THE ENVIRONMENTAL IMPACT OF PIG PRODUCTION}

\section{Background}

A farmer is approached by a feed producer, who promotes the use of a combination of probiotics (microorganisms) and phytogenic substances for improved weight gain in pig production (increase of $25-100 \mathrm{~kg}$ ). The farmer wants to ensure that this new feed has a positive impact on the environmental footprint of the farm. The farmer currently produces feed on the farm. According to the feed producer, the composition of the feed (feed ingredients produced on the farm and bought on the market) remains unchanged and the mixture is introduced at an incorporation rate of $700 \mathrm{mg} / \mathrm{kg}$ feed.

\section{Baseline scenario}

The feed formulation is based on feed ingredients that are produced on the farm and bought in the marketplace. The farmer has already made an evaluation of the environmental footprint of this feed, based on the LEAP guidelines on the environmental footprint of feed (FAO, 2016a). The current performance on the farm is described in Table A2.9.

Table A2.9: Current pig performance on the farm

\begin{tabular}{ll} 
Pig performance index & Performance \\
Initial body weight $(\mathrm{kg})$ & 27.5 \\
\hline Final body weight $(\mathrm{kg})$ & 112 \\
\hline Duration (days) & 100 \\
\hline Average daily gain (g/day) & 850 \\
\hline Mortality $(\%)$ & 2.7 \\
\hline Feed consumed $(\mathrm{kg})$ & 234 \\
\hline Feed conversion rate & 2.77 \\
\hline
\end{tabular}

\section{Evaluated scenario}

The feed producer promoting the product has organized three comparison trials among farmers in the same area adopting a similar type of diet and the results obtained seem to apply to the farm in the study. According to the information provided, the mixture proposed increases the average daily gain by 2.5 percent $\left(\Phi_{\mathrm{gp}}=1.025\right)$ and reduces the feed conversion rate by 3 percent $\left(\Phi_{\mathrm{fi}}=0.97\right)$.

The results to be expected by the farmer using the mixture are presented in Table A2.10.

Table A2.10: Expected pig performance on the farm with the incorporation of the proposed mixture

\begin{tabular}{lccc} 
Pig performance index & Actual performance & Expected performance & Variation \\
Initial body weight $(\mathrm{kg})$ & 27.5 & 27.5 & $0 \%$ \\
\hline Final body weight $(\mathrm{kg})$ & 112 & 112 & $0 \%$ \\
\hline Duration (days) & 100 & 97 & $-3 \%$ \\
\hline Average daily gain $(\mathrm{g} /$ day) & 850 & 871 & $+2.5 \%$ \\
\hline Mortality $(\%)$ & 2.7 & 2.7 & $0 \%$ \\
\hline Feed consumed $(\mathrm{kg})$ & 234 & 227 & $-3 \%$ \\
\hline Feed conversion rate & 2.77 & 2.69 & $-3 \%$ \\
\hline
\end{tabular}


To evaluate the impact of the scenario on the environmental footprint of $1 \mathrm{~kg}$ of pig live weight, the farmer will follow the steps below:

- Step 1: Collect data on the environmental footprint of the mixture from the feed producer. This environmental footprint is calculated considering:

- the environmental footprint of each of the phytogenic substances (see subsection 4.1.2 [ii] for the extraction process);

- the environmental footprint of the microorganism preparation used in the mixture (see subsection 4.1.2 [iv] for the fermentation process and subsection 4.1.3 to produce the preparation); and

- the environmental footprint of the mixture (using the guidelines on the environmental assessment of feed production [FAO, 2016a], including the footprint of eventual carriers).

- Step 2: Add the environmental footprint of the mixture to the calculated environmental footprint of the diet.

- Step 3: Calculate the potential impact of the performance improvement on the environmental footprint of the pig production (subsection 6.10.4 and Tables 28 and 29).

Table A2.11 presents the changes in the basis for calculation linked to the changes in feed intake, Table A2.12 the changes related to the change in growth rate and Table A2.13 the calculated impacts.

Table A2.11: Evaluation of the variation in emissions linked to the change in feed intake

\begin{tabular}{|c|c|}
\hline & Basis for calculation \\
\hline Equation FA-1 & $\begin{array}{c}\mathrm{N}_{\text {intake }}\left(\Phi_{\mathrm{fi}}\right)(\mathrm{kg})=\Sigma\left(\mathrm{FI}_{\mathrm{Ph}} \times \Phi_{\mathrm{fi}} \times\left(\% \mathrm{CP}_{\mathrm{Ph}} / 100\right)\right) / 6.25 \\
\text { Initial: } \mathrm{N}_{\text {intake }}\left(\Phi_{\mathrm{fi}}\right)(\mathrm{kg})=(70 \times 15 / 100+100 \times 14 / 100+64 \times 13 / 100) / 6.25=5.25 \mathrm{~kg} \\
\text { New: } \mathrm{N}_{\text {intake }}\left(\Phi_{\mathrm{fi}}\right)(\mathrm{kg})=(70 \times 0.97 \times 15 / 100+100 \times 0.97 \times 14 / 100+64 \times 0.97 \times 13 / 100) / 6.25= \\
5.09 \mathrm{~kg}\end{array}$ \\
\hline Equation FA-3 & $\begin{array}{c}P_{\text {intake }}\left(\Phi_{\text {fi }}\right)(\mathrm{kg})=\Sigma\left(\mathrm{FI}_{\mathrm{Ph}} \times \Phi_{\mathrm{fi}} \times \% \mathrm{P}_{\text {totalPh }}\right) / 100 \\
\text { Initial: } \mathrm{P}_{\text {intake }}\left(\Phi_{\mathrm{fi}}\right)(\mathrm{kg})=70 \times 0.2 / 100+100 \times 0.2 / 100+64 \times 0.2 / 100=1.62 \mathrm{~kg} \\
\mathrm{New}: \mathrm{P}_{\text {intake }}\left(\Phi_{\mathrm{fi}}\right)(\mathrm{kg})=70 \times 0.97 \times 0.2 / 100+100 \times 0.97 \times 0.2 / 100+64 \times 0.97 \times 0.2 / 100=1.57 \mathrm{~kg}\end{array}$ \\
\hline Equation FA-5 & $\begin{array}{c}\mathrm{Cu}_{\text {intake }}\left(\Phi_{\mathrm{f}}\right)(\mathrm{kg})=\Sigma\left(\mathrm{FI}_{\mathrm{Ph}} \times \Phi_{\mathrm{fi}} \times \% \mathrm{Cu}_{\mathrm{Ph}}\right) / 100 \\
\text { Initial: } \mathrm{Cu}_{\text {intake }}\left(\Phi_{\mathrm{fi}}\right)(\mathrm{kg})=70 \times 0.01 / 100+100 \times 0.01 / 100+64 \times 0.01 / 100=0.0234 \mathrm{~kg} \\
\text { New: } \mathrm{Cu}_{\text {intake }}\left(\Phi_{\mathrm{fi}}\right)(\mathrm{kg})=70 \times 0.97 \times 0.01 / 100+100 \times 0.97 \times 0.01 / 100+64 \times 0.97 \times 0.01 / 100= \\
0.0226 \mathrm{~kg}\end{array}$ \\
\hline Equation FA-7 & $\begin{array}{c}\mathrm{Zn}_{\text {intake }}\left(\Phi_{\mathrm{fi}}\right)(\mathrm{kg})=\Sigma\left(\mathrm{FI}_{\mathrm{Ph}} \times \Phi_{\mathrm{fi}} \times \% \mathrm{Zn}_{\mathrm{Ph}}\right) / 100 \\
\text { Initial: } \mathrm{Zn}_{\text {intake }}\left(\Phi_{\mathrm{fi}}\right)(\mathrm{kg})=70 \times 0.02 / 100+100 \times 0.02 / 100+64 \times 0.02 / 100=0.0468 \mathrm{~kg} \\
\text { New: } \mathrm{Zn}_{\text {intake }}\left(\Phi_{\mathrm{fi}}\right)(\mathrm{kg})=70 \times 0.97 \times 0.02 / 100+100 \times 0.97 \times 0.02 / 100+64 \times 0.97 \times 0.02 / 100= \\
0.0452 \mathrm{~kg}\end{array}$ \\
\hline Equation PI-8 & $\begin{array}{c}\operatorname{VS}\left(\Phi_{\mathrm{fi}}\right)(\mathrm{kg})=\Sigma\left(\mathrm{FI}_{\mathrm{Ph}} \times \Phi_{\mathrm{fi}} \times(1-\mathrm{DMD}) \times(1-\mathrm{A})+\mathrm{VS}_{\mathrm{WF}}\right) \\
\text { Initial: } \mathrm{VS}\left(\Phi_{\mathrm{fi}}\right)(\mathrm{kg})=70 \times(1-0.95) \times(1-0.2)+100 \times(1-0.95) \times(1-0.2)+64 \times(1-0.95) \times \\
\quad(1-0.2)+5.70=17.17 \mathrm{~kg} \\
\text { New: VS }\left(\Phi_{\mathrm{fi}}\right)(\mathrm{kg})=70 \times 0.97 \times(1-0.95) \times(1-0.2)+100 \times 0.97 \times(1-0.95) \times(1-0.2)+64 \times \\
0.97 \times(1-0.95) \times(1-0.2)+5.53=16.65 \mathrm{~kg}\end{array}$ \\
\hline Equation PI-9 & 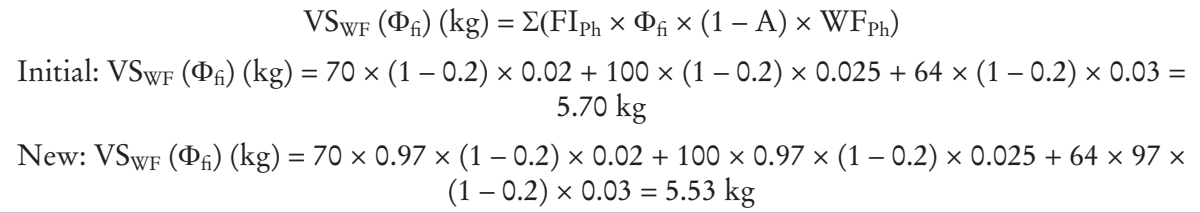 \\
\hline
\end{tabular}




\section{Calculated impacts}

Total

\begin{tabular}{|c|c|}
\hline Equation PI-11 & $\begin{array}{c}\mathrm{N}_{\text {excreted }}\left(\Phi_{\mathrm{fi}}\right)(\mathrm{kg})=\mathrm{N}_{\text {intake }}\left(\Phi_{\mathrm{fi}}\right)-\mathrm{N}_{\text {retention }} \\
\text { Initial: } \mathrm{N}_{\text {excreted }}\left(\Phi_{\mathrm{fi}}\right)(\mathrm{kg})=5.25-84.5 \times 25 / 100 / 6.25=1.87 \mathrm{~kg} \\
\text { New: } \mathrm{N}_{\text {excreted }}\left(\Phi_{\mathrm{fi}}\right)(\mathrm{kg})=5.09-84.5 \times 25 / 100 / 6.25=1.71 \mathrm{~kg}\end{array}$ \\
\hline Equation PI-12 & $\begin{array}{c}\mathrm{P}_{\text {excreted }}\left(\Phi_{\mathrm{fi}}\right)(\mathrm{kg})=\mathrm{P}_{\text {intake }}\left(\Phi_{\mathrm{fi}}\right)-\mathrm{P}_{\text {retention }} \\
\text { Initial: } \mathrm{P}_{\text {excreted }}\left(\Phi_{\mathrm{f}}\right)(\mathrm{kg})=1.62-84.5 \times 0.5 / 100=1.20 \mathrm{~kg} \\
\text { New: } \mathrm{P}_{\text {excreted }}\left(\Phi_{\mathrm{fi}}\right)(\mathrm{kg})=1.57-84.5 \times 0.5 / 100=1.15 \mathrm{~kg}\end{array}$ \\
\hline Equation FA-13 & $\begin{array}{c}\mathrm{Cu}_{\text {excrete }}\left(\Phi_{\mathrm{fi}}\right)(\mathrm{kg})=\mathrm{Cu}_{\text {intake }}\left(\Phi_{\mathrm{fi}}\right)-\mathrm{Cu}_{\text {retention }} \\
\text { Initial: } \mathrm{Cu}_{\text {excreted }}\left(\Phi_{\mathrm{f}}\right)(\mathrm{kg})=0.0234-84.5 \times 0.003 / 100=0.0209 \mathrm{~kg} \\
\mathrm{New}: \mathrm{Cu}_{\text {excreted }}\left(\Phi_{\mathrm{fi}}\right)(\mathrm{kg})=0.0226-84.5 \times 0.003 / 100=0.0201 \mathrm{~kg}\end{array}$ \\
\hline Equation FA-14 & $\begin{array}{c}\mathrm{Zn}_{\text {excreted }}\left(\Phi_{\mathrm{fi}}\right)(\mathrm{kg})=\mathrm{Zn}_{\text {intake }}\left(\Phi_{\mathrm{fi}}\right)-\mathrm{Zn}_{\text {retention }} \\
\text { Initial: } \mathrm{Zn}_{\text {excreted }}\left(\Phi_{\mathrm{fi}}\right)(\mathrm{kg})=0.0468-84.5 \times 0.015 / 100=0.0341 \mathrm{~kg} \\
\text { New: } \mathrm{Zn}_{\text {excreted }}\left(\Phi_{\mathrm{fi}}\right)(\mathrm{kg})=0.0452-84.5 \times 0.015 / 100=0.0325 \mathrm{~kg}\end{array}$ \\
\hline Equation FA-16 & $\begin{array}{c}\mathrm{CH}_{4 \text { manure }}\left(\Phi_{\mathrm{fi}}\right)(\mathrm{kg})=\mathrm{VS} \times \mathrm{Bo} \times \mathrm{MCF} \times 0.662 \\
\text { Initial: } \mathrm{CH}_{4 \text { manure }}\left(\Phi_{\mathrm{fi}}\right)(\mathrm{kg})=17.17 \times 0.45 \times 0.26 \times 0.662=1.330 \mathrm{~kg} \\
\text { New: } \mathrm{CH}_{4 \text { manure }}\left(\Phi_{\mathrm{fi}}\right)(\mathrm{kg})=16.65 \times 0.45 \times 0.26 \times 0.662=1.290 \mathrm{~kg}\end{array}$ \\
\hline Equation FA-17 & $\begin{array}{c}\mathrm{N}_{2} \mathrm{O}_{\text {manure }}\left(\Phi_{\mathrm{fi}}\right)(\mathrm{kg})=\mathrm{N}_{\text {excreted }}\left(\Phi_{\mathrm{fi}}\right) \times\left(1-\mathrm{R}_{\mathrm{MMS}}\right) \times \mathrm{EF}_{\mathrm{MMS}} \times 44 / 28 \\
\text { Initial: } \mathrm{N}_{2} \mathrm{O}_{\text {manure }}\left(\Phi_{\mathrm{fi}}\right)(\mathrm{kg})=1.87 \times(1-0.15) \times 0.005 \times 44 / 28=0.0125 \mathrm{~kg} \\
\text { New: } \mathrm{N}_{2} \mathrm{O}_{\text {manure }}\left(\Phi_{\mathrm{fi}}\right)(\mathrm{kg})=1.71 \times(1-0.15) \times 0.005 \times 44 / 28=0.0114 \mathrm{~kg}\end{array}$ \\
\hline & Intensity \\
\hline Equation PI-18 & $\begin{array}{c}\mathrm{N}_{\text {excreted }} \text { Intensity }\left(\Phi_{\mathrm{fi}}\right)(\mathrm{kg} / \mathrm{kg} \text { live weight })=\mathrm{N}_{\text {excreted }}\left(\Phi_{\mathrm{f}}\right) / \mathrm{TWG} \\
\text { Initial: } \mathrm{N}_{\text {excreted }} \text { Intensity }\left(\Phi_{\mathrm{fi}}\right)(\mathrm{kg} / \mathrm{kg} \text { live weight })=1.87 / 84.5=0.022 \\
\mathrm{New}: \mathrm{N}_{\text {excreted }} \text { Intensity }\left(\Phi_{\mathrm{f}}\right)(\mathrm{kg} / \mathrm{kg} \text { live weight })=1.71 / 84.5=0.020\end{array}$ \\
\hline Equation PI-19 & $\begin{array}{c}\mathrm{P}_{\text {excreted }} \text { Intensity }\left(\Phi_{\mathrm{fi}}\right)(\mathrm{kg} / \mathrm{kg} \text { live weight })=\mathrm{P}_{\text {excreted }}\left(\Phi_{\mathrm{fi}}\right) / \mathrm{TWG} \\
\text { Initial: } \mathrm{P}_{\text {excreted }} \text { Intensity }\left(\Phi_{\mathrm{fi}}\right)(\mathrm{kg} / \mathrm{kg} \text { live weight })=1.20 / 84.5=0.0142 \\
\text { New: } \mathrm{P}_{\text {excreted }} \text { Intensity }\left(\Phi_{\mathrm{fi}}\right)(\mathrm{kg} / \mathrm{kg} \text { live weight })=1.15 / 84.5=0.0136\end{array}$ \\
\hline Equation FA-20 & $\begin{array}{c}\mathrm{Cu}_{\text {excreted }} \text { Intensity }\left(\Phi_{\mathrm{fi}}\right)(\mathrm{kg} / \mathrm{kg} \text { live weight })=\mathrm{Cu}_{\text {excreted }}\left(\Phi_{\mathrm{fi}}\right) / \mathrm{TWG} \\
\text { Initial: } \mathrm{Cu}_{\text {excreted }} \text { Intensity }\left(\Phi_{\mathrm{f}}\right)(\mathrm{kg} / \mathrm{kg} \text { live weight })=0.0209 / 84.5=0.00025 \\
\text { New: } \mathrm{Cu}_{\text {excreted }} \text { Intensity }\left(\Phi_{\mathrm{fi}}\right)(\mathrm{kg} / \mathrm{kg} \text { live weight })=0.0201 / 84.5=0.00024\end{array}$ \\
\hline Equation FA-21 & $\begin{array}{c}\mathrm{Zn}_{\text {excreted }} \text { Intensity }\left(\Phi_{\mathrm{f}}\right)(\mathrm{kg} / \mathrm{kg} \text { live weight })=\mathrm{Zn}_{\text {excreted }}\left(\Phi_{\mathrm{f}}\right) / \mathrm{TWG} \\
\text { Initial: } \mathrm{Zn}_{\text {excreted }} \text { Intensity }\left(\Phi_{\mathrm{f}}\right)(\mathrm{kg} / \mathrm{kg} \text { live weight })=0.0341 / 84.5=0.00040 \\
\text { New: } \mathrm{Zn}_{\text {excreted }} \text { Intensity }\left(\Phi_{\mathrm{fi}}\right)(\mathrm{kg} / \mathrm{kg} \text { live weight })=0.0325 / 84.5=0.00038\end{array}$ \\
\hline Equation PI-23 & $\begin{array}{c}\mathrm{CH}_{4 \text { manure }} \text { Intensity }\left(\Phi_{\mathrm{fi}}\right)(\mathrm{kg} / \mathrm{kg} \text { live weight })=\mathrm{CH}_{4 \text { manure }}\left(\Phi_{\mathrm{fi}} / \mathrm{TWG}\right. \\
\text { Initial: } \mathrm{CH}_{4 \text { manure }} \text { Intensity }\left(\Phi_{\mathrm{fi}}\right)(\mathrm{kg} / \mathrm{kg} \text { live weight })=1.330 / 84.5=0.016 \\
\text { New: } \mathrm{CH}_{4 \text { manure }} \text { Intensity }\left(\Phi_{\mathrm{fi}}\right)(\mathrm{kg} / \mathrm{kg} \text { live weight })=1.290 / 84.5=0.015\end{array}$ \\
\hline Equation PI-24 & $\begin{array}{c}\mathrm{N}_{2} \mathrm{O}_{\text {manure }} \text { Intensity }\left(\Phi_{\mathrm{fi}}\right)(\mathrm{kg} / \mathrm{kg} \text { live weight })=\mathrm{N}_{2} \mathrm{O}_{\text {manure }}\left(\Phi_{\mathrm{fi}}\right) / \mathrm{TWG} \\
\text { Initial: } \mathrm{N}_{2} \mathrm{O}_{\text {manure }} \text { Intensity }\left(\Phi_{\mathrm{fi}}\right)(\mathrm{kg} / \mathrm{kg} \text { live weight })=0.0125 / 84.5=0.00015 \\
\text { New: } \mathrm{N}_{2} \mathrm{O}_{\text {manure }} \text { Intensity }\left(\Phi_{\mathrm{fi}}\right)(\mathrm{kg} / \mathrm{kg} \text { live weight })=0.0114 / 84.5=0.00013\end{array}$ \\
\hline
\end{tabular}


Table A2.12: Evaluation of the variation in emissions linked to the change in weight gain

\begin{tabular}{|c|c|}
\hline & Basis for calculation \\
\hline Equation FA-2 & $\begin{array}{c}\mathrm{N}_{\text {retention }}\left(\Phi_{\mathrm{gp}}\right)(\mathrm{kg})=\left(\mathrm{TWG} \times \Phi_{\mathrm{gp}} \times \% \text { Protein in tissues } / 100\right) / 6.25 \\
\text { Initial: } \mathrm{N}_{\text {retention }}\left(\Phi_{\mathrm{gp}}\right)(\mathrm{kg})=84.5 \times 25 / 100 / 6.25=3.38 \mathrm{~kg} \\
\text { New: } \mathrm{N}_{\text {retention }}\left(\Phi_{\mathrm{gp}}\right)(\mathrm{kg})=84.5 \times 1 \times 25 / 100 / 6.25=3.38 \mathrm{~kg}\end{array}$ \\
\hline Equation FA-4 & $\begin{array}{c}\mathrm{P}_{\text {retention }}\left(\Phi_{\mathrm{gp}}\right)(\mathrm{kg})=\mathrm{TWG} \times \Phi_{\mathrm{gp}} \times \% \mathrm{P} \text { in tissues and bones } / 100 \\
\text { Initial: } \mathrm{P}_{\text {retention }}\left(\Phi_{\mathrm{gp}}\right)(\mathrm{kg})=84.5 \times 0.5 / 100=0.42 \mathrm{~kg} \\
\mathrm{New}: \mathrm{P}_{\text {retention }}\left(\Phi_{\mathrm{gp}}\right)(\mathrm{kg})=84.5 \times 1 \times 0.5 / 100=0.42 \mathrm{~kg}\end{array}$ \\
\hline Equation FA-6 & $\begin{array}{c}\mathrm{Cu}_{\text {retention }}\left(\Phi_{\mathrm{gp}}\right)(\mathrm{kg})=\mathrm{TWG} \times \Phi_{\mathrm{gp}} \times \% \mathrm{Cu} \text { in tissues and bones } / 100 \\
\text { Initial: } \mathrm{Cu}_{\text {retention }}\left(\Phi_{\mathrm{gp}}\right)(\mathrm{kg})=84.5 \times 0.003 / 100=0.0025 \mathrm{~kg} \\
\mathrm{New}: \mathrm{Cu}_{\text {retention }}\left(\Phi_{\mathrm{gp}}\right)(\mathrm{kg})=84.5 \times 1 \times 0.003 / 100=0.0025 \mathrm{~kg}\end{array}$ \\
\hline Equation FA-8 & $\begin{array}{c}\mathrm{Zn}_{\text {retention }}\left(\Phi_{\mathrm{gp}}\right)(\mathrm{kg})=\mathrm{TWG} \times \Phi_{\mathrm{gp}} \times \% \mathrm{Zn} \text { in tissues and bones } \\
\quad \text { Initial: } \mathrm{Zn}_{\text {retention }}\left(\Phi_{\mathrm{gp}}\right)(\mathrm{kg})=84.5 \times 0.015 / 100=0.0127 \mathrm{~kg} \\
\text { New: } \mathrm{Zn}_{\text {retention }}\left(\Phi_{\mathrm{gp}}\right)(\mathrm{kg})=84.5 \times 1 \times 0.015 / 100=0.0127 \mathrm{~kg}\end{array}$ \\
\hline
\end{tabular}

Table A2.13: Evaluation of the impact on the environmental footprint linked to performance improvement

\begin{tabular}{|c|c|}
\hline & Calculated impacts \\
\hline & Total \\
\hline \multirow[t]{3}{*}{ Equation PI-11 } & $\mathrm{N}_{\text {excreted }}\left(\Phi_{\mathrm{gp}}\right)(\mathrm{kg})=\mathrm{N}_{\text {intake }}-\mathrm{N}_{\text {retention }}\left(\Phi_{\mathrm{gp}}\right)$ \\
\hline & Initial: $\mathrm{N}_{\text {excreted }}\left(\Phi_{\mathrm{gp}}\right)(\mathrm{kg})=5.25-3.38=1.87 \mathrm{~kg}$ \\
\hline & New: $\mathrm{N}_{\text {excreted }}\left(\Phi_{\mathrm{gp}}\right)(\mathrm{kg})=5.09-3.38=1.71 \mathrm{~kg}$ \\
\hline \multirow[t]{3}{*}{ Equation PI-12 } & $\mathrm{P}_{\text {excreted }}\left(\Phi_{\mathrm{gp}}\right)(\mathrm{kg})=\mathrm{P}_{\text {intake }}-\mathrm{P}_{\text {retention }}\left(\Phi_{\mathrm{gp}}\right)$ \\
\hline & Initial: $\mathrm{N}_{\text {excreted }}\left(\Phi_{\mathrm{gp}}\right)(\mathrm{kg})=1.62-0.42=1.20 \mathrm{~kg}$ \\
\hline & New: $\mathrm{N}_{\text {excreted }}\left(\Phi_{\mathrm{gp}}\right)(\mathrm{kg})=1.57-0.42=1.15 \mathrm{~kg}$ \\
\hline \multirow[t]{3}{*}{ Equation FA-13 } & $\mathrm{Cu}_{\text {excreted }}\left(\Phi_{\mathrm{gp}}\right)(\mathrm{kg})=\mathrm{Cu}_{\text {intake }}-\mathrm{Cu}_{\text {retention }}\left(\Phi_{\mathrm{gp}}\right)$ \\
\hline & Initial: $\mathrm{Cu}_{\text {excreted }}\left(\Phi_{\mathrm{gp}}\right)(\mathrm{kg})=0.0234-0.0025=0.0209 \mathrm{~kg}$ \\
\hline & New: $\mathrm{Cu}_{\text {excreted }}\left(\Phi_{\mathrm{gp}}\right)(\mathrm{kg})=0.0226-0.0025=0.0201 \mathrm{~kg}$ \\
\hline \multirow[t]{3}{*}{ Equation FA-14 } & $\mathrm{Zn}_{\text {excreted }}\left(\Phi_{\mathrm{gp}}\right)(\mathrm{kg})=\mathrm{Zn}_{\text {intake }}-\mathrm{Zn}_{\text {retention }}\left(\Phi_{\mathrm{gp}}\right)$ \\
\hline & Initial: $\mathrm{Zn}_{\text {excreted }}\left(\Phi_{\mathrm{gp}}\right)(\mathrm{kg})=0.0341-0.0127=0.0214 \mathrm{~kg}$ \\
\hline & New: $Z_{n_{\text {excreted }}}\left(\Phi_{\mathrm{gp}}\right)(\mathrm{kg})=0.0325-0.0127=0.0198 \mathrm{~kg}$ \\
\hline \multirow[t]{4}{*}{ Equation PI-17 } & $\mathrm{N}_{2} \mathrm{O}_{\text {manure }}\left(\Phi_{\mathrm{gp}}\right)(\mathrm{kg})=\mathrm{N}_{\text {excreted }}\left(\Phi_{\mathrm{gp}}\right) \times\left(1-\mathrm{R}_{\mathrm{MMS}}\right) \times \mathrm{EF}_{\mathrm{MMS}} \times 44 / 28$ \\
\hline & Initial: $\mathrm{N}_{2} \mathrm{O}_{\text {manure }}\left(\Phi_{\mathrm{gp}}\right)(\mathrm{kg})=1.87 \times(1-0.15) \times 0.005 \times 44 / 28=0.0125 \mathrm{~kg}$ \\
\hline & New: $\mathrm{N}_{2} \mathrm{O}_{\text {manure }}\left(\Phi_{\mathrm{gp}}\right)(\mathrm{kg})=1.71 \times(1-0.15) \times 0.005 \times 44 / 28=0.0114 \mathrm{~kg}$ \\
\hline & Intensity \\
\hline \multirow[t]{3}{*}{ Equation PI-18 } & $\mathrm{N}_{\text {excreted }}$ Intensity $\left(\Phi_{\mathrm{gp}}\right)(\mathrm{kg} / \mathrm{kg}$ live weight $)=\mathrm{N}_{\text {excreted }}\left(\Phi_{\mathrm{gp}}\right) / \mathrm{TWG}\left(\Phi_{\mathrm{gp}}\right)$ \\
\hline & Initial: $\mathrm{N}_{\text {excreted }}$ Intensity $\left(\Phi_{\mathrm{gp}}\right)(\mathrm{kg} / \mathrm{kg}$ live weight $)=1.87 / 84.5=0.022$ \\
\hline & New: $\mathrm{N}_{\text {excreted }}$ Intensity $\left(\Phi_{\mathrm{gp}}\right)(\mathrm{kg} / \mathrm{kg}$ live weight $)=1.71 / 84.5=0.020$ \\
\hline \multirow[t]{3}{*}{ Equation PI-19 } & $\mathrm{P}_{\text {excreted }}$ Intensity $\left(\Phi_{\mathrm{gp}}\right)(\mathrm{kg} / \mathrm{kg}$ live weight $)=\mathrm{P}_{\text {excreted }}\left(\Phi_{\mathrm{gp}}\right) / \mathrm{TWG}\left(\Phi_{\mathrm{gp}}\right)$ \\
\hline & Initial: $\mathrm{P}_{\text {excreted }}$ Intensity $\left(\Phi_{\mathrm{gp}}\right)(\mathrm{kg} / \mathrm{kg}$ live weight $)=1.20 / 84.5=0.0142$ \\
\hline & New: $P_{\text {excreted }}$ Intensity $\left(\Phi_{\mathrm{gp}}\right)(\mathrm{kg} / \mathrm{kg}$ live weight $)=1.15 / 84.5=0.0136$ \\
\hline \multirow[t]{3}{*}{ Equation FA-20 } & $\mathrm{Cu}_{\text {excreted }}$ Intensity $\left(\Phi_{\mathrm{gp}}\right)(\mathrm{kg} / \mathrm{kg}$ live weight $)=\mathrm{Cu}_{\text {excreted }}\left(\Phi_{\mathrm{gp}}\right) / \mathrm{TWG}\left(\Phi_{\mathrm{gp}}\right)$ \\
\hline & Initial: $\mathrm{Cu}_{\text {excreted }}$ Intensity $\left(\Phi_{\mathrm{gp}}\right)(\mathrm{kg} / \mathrm{kg}$ live weight $)=0.0209 / 84.5=0.00025$ \\
\hline & New: $\mathrm{Cu}_{\text {excreted }}$ Intensity $\left(\Phi_{\mathrm{gp}}\right)(\mathrm{kg} / \mathrm{kg}$ live weight $)=0.0201 / 84.5=0.00024$ \\
\hline
\end{tabular}




\begin{tabular}{lc}
\hline Equation FA-21 & $\mathrm{Zn}_{\text {excreted }}$ Intensity $\left(\Phi_{\mathrm{gp}}\right)(\mathrm{kg} / \mathrm{kg}$ live weight $)=\mathrm{Zn}_{\text {excreted }}\left(\Phi_{\mathrm{gp}}\right) / \mathrm{TWG}\left(\Phi_{\mathrm{gp}}\right)$ \\
& Initial: $\mathrm{Zn}_{\text {excreted }}$ Intensity $\left(\Phi_{\mathrm{gp}}\right)(\mathrm{kg} / \mathrm{kg}$ live weight $)=0.0214 / 84.5=0.00025$ \\
& $\mathrm{New}: \mathrm{Zn}_{\text {excreted }}$ Intensity $\left(\Phi_{\mathrm{gp}}\right)(\mathrm{kg} / \mathrm{kg}$ live weight $)=0.0198 / 84.5=0.00023$ \\
\hline Equation FI-24 & $\mathrm{N}_{2} \mathrm{O}_{\text {manure }}$ Intensity $\left(\Phi_{\mathrm{gp}}\right)(\mathrm{kg} / \mathrm{kg}$ live weight $)=\mathrm{N}_{2} \mathrm{O}_{\text {manure }}\left(\Phi_{\mathrm{gp}}\right) / \mathrm{TWG}\left(\Phi_{\mathrm{gp}}\right)$ \\
Initial: $\mathrm{N}_{2} \mathrm{O}_{\text {manure }}$ Intensity $\left(\Phi_{\mathrm{gp}}\right)(\mathrm{kg} / \mathrm{kg}$ live weight $)=0.0125 / 84.5=0.00015$ \\
$\mathrm{New}: \mathrm{N}_{2} \mathrm{O}_{\text {manure }}$ Intensity $\left(\Phi_{\mathrm{gp}}\right)(\mathrm{kg} / \mathrm{kg}$ live weight $)=0.0114 / 84.5=0.0013$ \\
\hline
\end{tabular}

The use of the mixture during the production phase results in:

- a reduction of the nitrogen excretion, linked to the reduced feed intake (-9\%)

- a reduction of the phosphorus excretion, linked to the reduced feed intake $(-4 \%)$

leading to a reduction of the risk for eutrophication and acidification.

In addition, the reduction of volatile solids by 3 percent leads to a reduction of methane emission, hence the GWP of the production.

Furthermore, the reduction of the time to market ( 3 days less in the building) may reduce further the impact linked to housing.

Sensitivity analysis

Based on the substantiation of the claim, it is not necessary to run a sensitivity analysis. A postapplication evaluation, based on actual data from the farm might be appropriate.

\section{Conclusion}

The net results shall inform the choice of the pig farmer, who will be in a position to evaluate whether or not the proposed mixture is appropriate for his farm. 


\section{CASE STUDY 4: MODIFICATION OF THE NUTRITIONAL COMPOSITION OF THE FEED THROUGH FEED ADDITIVES}

\section{Background}

A brand owner of eggs is evaluating the potential mitigation measures for reducing the environmental footprint of his eggs and egg products commercialized in Latin America. For this purpose and with the help of one of his feed suppliers, he envisages reducing the crude protein and the total phosphorus concentration of the feed provided to the animals. The feed miller supplies the brand owner with a study demonstrating the potential effect of the use of amino acids and phytase as a tool to modify his feeds.

\section{Baseline scenario}

The current feed for layers used in the brand owner's supplying farms is based on corn and soybean meal (Table A2.14).

Table A2.14: Composition and nutritional characteristic of the current layer feed

\begin{tabular}{ll} 
Ingredients & \\
\hline Composition $(\mathrm{g} / \mathrm{kg})$ & 54.9 \\
\hline Corn & 29.7 \\
\hline Soybean meal & 9.36 \\
\hline Vegetable oil & 3.43 \\
\hline Dicalcium phosphate & 1.67 \\
\hline Salt & 0.417 \\
\hline Premix & 0.310 \\
\hline dl-methionine & 0.211 \\
\hline L-Lysine & 0.005 \\
\hline Nutritional characteristics $(\mathrm{kg})$ & \\
\hline Metabolizable energy (kcal) & 2871 \\
\hline Protein $(\%)$ & 18.5 \\
\hline Lysine $(\%)$ & 1.02 \\
\hline Methionine (\%) & 0.52 \\
\hline Calcium $(\%)$ & 3.30 \\
\hline Total phosphorus $(\%)$ & 0.50 \\
\hline
\end{tabular}

Table A2.15 shows the average performance achieved on the farm with this diet.

Table A2.15: Average performance of layer hens after 42 weeks with the current diet

\begin{tabular}{ll} 
Layer performance index & Layer performance \\
Egg production $(42$ weeks) & 265 \\
\hline Egg weight $(\mathrm{g} / \mathrm{egg})$ & 52.6 \\
\hline Total egg weight $(\mathrm{kg})$ & 13.9 \\
\hline Feed intake $(\mathrm{kg})$ & 26.3 \\
\hline Feed conversion ratio & 1.89 \\
\hline
\end{tabular}




\section{Evaluated scenario}

Based on the request from the egg brand owner, the feed producer proposes the use of additional amino acids (now available on the market) to reduce the crude protein concentration from 18.5 percent to 17.5 percent $\left(\Phi_{\mathrm{nc}}=0.946\right)$. Therefore, the diet composition will change with a reduction in the quantity of soybean meal and fat and an increased concentration of corn. In addition, by using phytase, the concentration of phosphorus is reduced from 0.5 percent to 0.36 percent $\left(\Phi_{\mathrm{nc}}=0.72\right)$. This is related to the decreased use of dicalcium phosphate and increased use of limestone.

Table A2.16 presents the final nutritional characteristics of the diet.

Table A2.16: Modification of the nutritional characteristics of the diet, when additional amino acids and phytase are added to the diet

\begin{tabular}{lccc} 
Nutritional characteristics $(\mathrm{kg})$ & Current diet & Revised diet & Variation \\
Metabolizable energy (kcal) & 2871 & 2871 & $0 \%$ \\
\hline Protein (\%) & 18.5 & 17.5 & $-5.4 \%$ \\
\hline Lysine (\%) & 1.02 & 1.02 & $0 \%$ \\
\hline Methionine (\%) & 0.52 & 0.52 & $0 \%$ \\
\hline Calcium (\%) & 3.30 & 3.30 & $0 \%$ \\
\hline Total phosphorus (\%) & 0.50 & 0.36 & $-28 \%$ \\
\hline
\end{tabular}

Based on the new nutritional characteristics, it is expected that the layer performance will remain unchanged compared to the baseline scenario.

To evaluate the impact on the environmental footprint of $1000 \mathrm{~kg}$ of eggs in shell, the feed producer will follow the steps below:

- Step 1: Collect data on the environmental footprint of the additional amino acids used in the diet (see subsection 4.1.2 [iv] for the fermentation process).

- Step 2: Collect data on the environmental footprint of the phytase preparation used in the diet (see subsection 4.1.2 [iv] for the fermentation process and subsection 4.1.3 for the production of the preparation).

- Step 3: Recalculate the environmental footprint of the new feed, considering the different ingredients used, following the guidelines on the environmental evaluation of feed.

- Step 4: Calculate the potential impact of the modification of the diet's nutritional characteristics on the environmental footprint of the egg production (subsection 6.10.4 and Table 46).

Table A2.17 provides the result of the evaluation on egg production. 
Table A2.17: Evaluation of the modification of the environmental footprint linked to the use of additional amino acids and phytase

\begin{tabular}{|c|c|}
\hline & Basis for calculation \\
\hline Equation FA-1 & $\begin{array}{c}P_{\text {intake }}\left(\Phi_{\text {nc }}\right)(\mathrm{kg})=\Sigma\left(\mathrm{FI}_{\mathrm{Ph}} \times \% \mathrm{P}_{\text {totalPh }} \times \Phi_{\mathrm{nc}}\right) / 100 \\
\text { Initial: } \mathrm{P}_{\text {intake }}\left(\Phi_{\mathrm{nc}}\right)(\mathrm{kg})=26.3 \times 0.5 / 100=0.1315 \mathrm{~kg} \\
\text { New: } \mathrm{P}_{\text {intake }}\left(\Phi_{\mathrm{nc}}\right)(\mathrm{kg})=26.3 \times 0.5 \times 0.72 / 100=0.0947 \mathrm{~kg}\end{array}$ \\
\hline Equation FA-3 & $\begin{array}{c}\mathrm{Cu}_{\text {intake }}\left(\Phi_{\mathrm{nc}}\right)(\mathrm{kg})=\Sigma\left(\mathrm{FI}_{\mathrm{Ph}} \times \% \mathrm{Cu}_{\mathrm{Ph}} \times \Phi_{\mathrm{nc}}\right) / 100 \\
\text { Initial: } \mathrm{Cu}_{\text {intake }}\left(\Phi_{\mathrm{nc}}\right)(\mathrm{kg})=26.3 \times 0.02 / 100=0.00526 \mathrm{~kg} \\
\mathrm{New}: \mathrm{Cu}_{\text {intake }}\left(\Phi_{\mathrm{nc}}\right)(\mathrm{kg})=26.3 \times 1 \times 0.02 / 100=0.00526 \mathrm{~kg}\end{array}$ \\
\hline Equation FA-5 & $\begin{array}{c}\mathrm{Zn}_{\text {intake }}\left(\Phi_{\mathrm{nc}}\right)(\mathrm{kg})=\Sigma\left(\mathrm{FI}_{\mathrm{Ph}} \times \% \mathrm{Zn}_{\mathrm{Ph}} \times \Phi_{\mathrm{nc}}\right) / 100 \\
\text { Initial: } \mathrm{Zn}_{\text {intake }}\left(\Phi_{\mathrm{nc}}\right)(\mathrm{kg})=26.3 \times 0.05 / 100=0.0132 \mathrm{~kg} \\
\text { New: } \mathrm{Zn}_{\text {intake }}\left(\Phi_{\mathrm{nc}}\right)(\mathrm{kg})=26.3 \times 1 \times 0.05 / 100=0.0132 \mathrm{~kg}\end{array}$ \\
\hline & Calculated impacts \\
\hline & Total \\
\hline Equation $\mathrm{PO}-8$ & $\begin{array}{c}\mathrm{N}_{\text {excreted }}\left(\Phi_{\mathrm{nc}}\right)(\mathrm{kg})=\Sigma\left(\mathrm{FI}_{\mathrm{Ph}} \times \% \mathrm{CP}_{\mathrm{Ph}} \times \Phi_{\mathrm{nc}} / 100 / 6.25 \times((0.0182 \times \mathrm{EW}) \times \mathrm{ENb})\right. \\
\text { Initial: } \mathrm{N}_{\text {excreted }}\left(\Phi_{\mathrm{nc}}\right)(\mathrm{kg})=26.3 \times 18.5 / 100 / 6.25 \times((0.0182 \times 52.6) \times 265)=197.49 \mathrm{~kg} \\
\text { New: } \mathrm{N}_{\text {excreted }}\left(\Phi_{\mathrm{nc}}\right)(\mathrm{kg})=26.3 \times 18.5 \times 0.946 / 100 / 6.25 \times((0.0182 \times 52.6) \times 265)=186.83 \mathrm{~kg}\end{array}$ \\
\hline Equation FA-9 & $\begin{array}{c}P_{\text {excreted }}\left(\Phi_{\text {nc }}\right)(\mathrm{kg})=P_{\text {intake }}\left(\Phi_{\text {nc }}\right)-P_{\text {retained }} \\
\text { Initial: } P_{\text {excreted }}\left(\Phi_{\mathrm{nc}}\right)(\mathrm{kg})=0.1315-13.9 \times 0.5 / 100=0.0695 \mathrm{~kg} \\
\text { New: } P_{\text {excreted }}\left(\Phi_{\mathrm{nc}}\right)(\mathrm{kg})=0.0947-13.9 \times 0.5 / 100=0.0252 \mathrm{~kg}\end{array}$ \\
\hline Equation FA-10 & $\begin{array}{c}\mathrm{Cu}_{\text {excreted }}\left(\Phi_{\mathrm{nc}}\right)(\mathrm{kg})=\mathrm{Cu}_{\text {intake }}\left(\Phi_{\mathrm{nc}}\right)-\mathrm{Cu}_{\text {retained }} \\
\text { Initial: } \mathrm{Cu}_{\text {excreted }}\left(\Phi_{\mathrm{nc}}\right)(\mathrm{kg})=0.00526-13.9 \times 0.02 / 100=0.00248 \mathrm{~kg} \\
\mathrm{New}: \mathrm{Cu}_{\text {excreted }}\left(\Phi_{\mathrm{nc}}\right)(\mathrm{kg})=0.00526-13.9 \times 0.02 / 100=0.00248 \mathrm{~kg}\end{array}$ \\
\hline Equation FA-11 & $\begin{array}{c}\mathrm{Zn}_{\text {excreted }}\left(\Phi_{\mathrm{nc}}\right)(\mathrm{kg})=\mathrm{Zn}_{\text {intake }}\left(\Phi_{\mathrm{nc}}\right)-\mathrm{Zn}_{\text {retained }} \\
\text { Initial: } \mathrm{Zn}_{\text {excreted }}\left(\Phi_{\mathrm{nc}}\right)(\mathrm{kg})=0.0132-13.9 \times 0.05 / 100=0.0625 \mathrm{~kg} \\
\text { New: } \mathrm{Zn}_{\text {excreted }}\left(\Phi_{\mathrm{nc}}\right)(\mathrm{kg})=0.0132-13.9 \times 0.05 / 100=0.0625 \mathrm{~kg}\end{array}$ \\
\hline Equation $\mathrm{PO}-13$ & $\begin{array}{c}\mathrm{N}_{2} \mathrm{O}_{\text {manure }}\left(\Phi_{\mathrm{nc}}\right)(\mathrm{kg})=\mathrm{N}_{\text {excreted }}\left(\Phi_{\mathrm{nc}}\right) \times \mathrm{EF}_{\mathrm{MMS}} \times 44 / 28 \\
\text { Initial: } \mathrm{N}_{2} \mathrm{O}_{\text {manure }}\left(\Phi_{\mathrm{nc}}\right)(\mathrm{kg})=197.49 \times 0.005 \times 44 / 28=1.552 \mathrm{~kg} \\
\mathrm{New}: \mathrm{N}_{2} \mathrm{O}_{\text {manure }}\left(\Phi_{\mathrm{nc}}\right)(\mathrm{kg})=186.83 \times 0.005 \times 44 / 28=1.468 \mathrm{~kg}\end{array}$ \\
\hline & Intensity \\
\hline Equation $\mathrm{PO}-14$ & $\begin{array}{l}\mathrm{N}_{\text {excreted }} \text { Intensity }\left(\Phi_{\mathrm{nc}}\right)(\mathrm{kg} / \mathrm{kg} \text { eggs in shell })=\mathrm{N}_{\text {excreted }}\left(\Phi_{\mathrm{nc}}\right) / \mathrm{kg} \text { eggs in shell } \\
\text { Initial: } \mathrm{N}_{\text {excreted }} \text { Intensity }\left(\Phi_{\mathrm{nc}}\right)(\mathrm{kg} / \mathrm{kg} \text { eggs in shell })=197.49 / 13.9=14 \\
\text { New: } \mathrm{N}_{\text {excreted }} \text { Intensity }\left(\Phi_{\mathrm{nc}}\right)(\mathrm{kg} / \mathrm{kg} \text { eggs in shell })=186.83 / 13.9=13.4\end{array}$ \\
\hline Equation FA-15 & $\begin{array}{l}P_{\text {excreted }} \text { Intensity }\left(\Phi_{\mathrm{nc}}\right)(\mathrm{kg} / \mathrm{kg} \text { eggs in shell })=\mathrm{P}_{\text {excreted }}\left(\Phi_{\mathrm{nc}}\right) / \mathrm{kg} \text { eggs in shell } \\
\text { Initial: } \mathrm{P}_{\text {excreted }} \text { Intensity }\left(\Phi_{\mathrm{nc}}\right)(\mathrm{kg} / \mathrm{kg} \text { eggs in shell })=0.0695 / 13.9=0.005 \\
\text { New: } P_{\text {excreted }} \text { Intensity }\left(\Phi_{\mathrm{nc}}\right)(\mathrm{kg} / \mathrm{kg} \text { eggs in shell })=0.0252 / 13.9=0.002\end{array}$ \\
\hline Equation FA-16 & $\begin{array}{l}\mathrm{Cu}_{\text {excreted }} \text { Intensity }\left(\Phi_{\mathrm{nc}}\right)(\mathrm{kg} / \mathrm{kg} \text { eggs in shell })=\mathrm{Cu}_{\text {excreted }}\left(\Phi_{\mathrm{nc}}\right) / \mathrm{kg} \text { eggs in shell } \\
\text { Initial: } \mathrm{Cu}_{\text {excreted }} \text { Intensity }\left(\Phi_{\mathrm{nc}}\right)(\mathrm{kg} / \mathrm{kg} \text { eggs in shell })=0.00248 / 3.9=0.00018 \\
\mathrm{New}: \mathrm{Cu}_{\text {excreted }} \text { Intensity }\left(\Phi_{\mathrm{nc}}\right)(\mathrm{kg} / \mathrm{kg} \text { eggs in shell })=0.00248 / 13.9=0.00018\end{array}$ \\
\hline Equation FA-17 & $\begin{array}{l}\mathrm{Zn}_{\text {excreted }} \text { Intensity }\left(\Phi_{\mathrm{nc}}\right)(\mathrm{kg} / \mathrm{kg} \text { eggs in shell })=\mathrm{Zn}_{\text {excreted }}\left(\Phi_{\mathrm{nc}}\right) / \mathrm{kg} \text { eggs in shell } \\
\text { Initial: } \mathrm{Zn}_{\text {excreted }} \text { Intensity }\left(\Phi_{\mathrm{nc}}\right)(\mathrm{kg} / \mathrm{kg} \text { eggs in shell })=0.0625 / 13.9=0.0045 \\
\text { New: } \mathrm{Zn}_{\text {excreted }} \text { Intensity }\left(\Phi_{\mathrm{nc}}\right)(\mathrm{kg} / \mathrm{kg} \text { eggs in shell })=0.0625 / 13.9=0.0045\end{array}$ \\
\hline Equation $\mathrm{PO}-19$ & $\begin{array}{c}\mathrm{N}_{2} \mathrm{O}_{\text {manure }} \text { Intensity }\left(\Phi_{\mathrm{nc}}\right)(\mathrm{kg} / \mathrm{kg} \text { eggs in shell })=\mathrm{N}_{2} \mathrm{O}_{\text {manure }}\left(\Phi_{\mathrm{nc}}\right) / \mathrm{kg} \text { eggs in shell } \\
\text { Initial: } \mathrm{N}_{2} \mathrm{O}_{\text {manure }} \text { Intensity }\left(\Phi_{\mathrm{nc}}\right)(\mathrm{kg} / \mathrm{kg} \text { eggs in shell })=1.552 / 13.9=0.112 \\
\text { New: } \mathrm{N}_{2} \mathrm{O}_{\text {manure }} \text { Intensity }\left(\Phi_{\mathrm{nc}}\right)(\mathrm{kg} / \mathrm{kg} \text { eggs in shell })=1.468 / 13.9=0.106\end{array}$ \\
\hline
\end{tabular}


The use of additional amino acids and phytase during the production results in:

- a reduction of the nitrogen excretion, linked to the reduced crude protein content in the $\operatorname{diet}(-5.4 \%)$

- a reduction of the phosphorus excretion, linked to the reduced phosphorus content in the diet

leading to a reduction of the risk of eutrophication and acidification.

In addition, due to the reduction of the nitrogen content in the manure, the emission of nitrous oxide is decreased by 5.4 percent, leading to a reduction of the GWP on farm.

The combination of the modification of the environmental footprint of the new feed formulation and the positive impact on the farm provides the overall environmental footprint of the egg production with the new formulation.

\section{Sensitivity analysis}

It is advised, unless there is sufficient evidence that the animal performance would remain unchanged, to organize for a sensitivity analysis which considers the animal performance modification linked to the new formulation.

As an example, assuming that the new feed formulation has an impact on the production of eggs $\left(5 \%\right.$ decrease, i.e. $\left.\Phi_{\text {ep }}=0.95\right)$, the new animal performance data are modified as indicated in Table A2.18.

Table A2.18: Influence of the change in performance (number of eggs laid) on the environmental footprint of laying production, when additional amino acids and phytase are used.

\begin{tabular}{|c|c|}
\hline & Basis for calculation \\
\hline \multirow[t]{3}{*}{ Equation FA-2 } & $\mathrm{P}_{\text {retention }}\left(\Phi_{\text {ep }}\right)(\mathrm{kg})=\mathrm{EW} \times \Phi_{\text {ep }} \times \mathrm{ENb} \times \Phi_{\text {ep }} \times \% \mathrm{P}$ eggs $/ 100$ \\
\hline & Initial: $\mathrm{P}_{\text {retention }}\left(\Phi_{\mathrm{ep}}\right)(\mathrm{kg})=0.0526 \times 265 \times 0.5 / 100=0.0697$ \\
\hline & New: $P_{\text {retention }}\left(\Phi_{\text {ep }}\right)(\mathrm{kg})=0.0526 \times 1 \times 265 \times 0.95 \times 0.5 / 100=0.0662$ \\
\hline \multirow[t]{3}{*}{ Equation FA-4 } & $\mathrm{Cu}_{\mathrm{retention}}\left(\Phi_{\mathrm{ep}}\right)(\mathrm{kg})=\mathrm{EW} \times \Phi_{\mathrm{ep}} \times \mathrm{ENb} \times \Phi_{\mathrm{ep}} \times \% \mathrm{Cu} / 100$ \\
\hline & Initial: $\mathrm{Cu}_{\mathrm{retention}}\left(\Phi_{\mathrm{ep}}\right)(\mathrm{kg})=0.0526 \times 265 \times 0.02 / 100=0.00279 \mathrm{~kg}$ \\
\hline & New: $\mathrm{Cu}_{\text {retention }}\left(\Phi_{\mathrm{ep}}\right)(\mathrm{kg})=0.0526 \times 1 \times 265 \times 0.95 \times 0.02 / 100=0.00265 \mathrm{~kg}$ \\
\hline \multirow[t]{5}{*}{ Equation FA-6 } & $\mathrm{Zn}_{\text {retention }}\left(\Phi_{\mathrm{ep}}\right)(\mathrm{kg})=\mathrm{EW} \times \Phi_{\mathrm{ep}} \times \mathrm{ENb} \times \Phi_{\mathrm{ep}} \times \% \mathrm{Zn} \mathrm{eggs} / 100$ \\
\hline & Initial: $\mathrm{Zn}_{\text {retention }}\left(\Phi_{\mathrm{ep}}\right)(\mathrm{kg})=0.0526 \times 265 \times 0.005 / 100=0.0070 \mathrm{~kg}$ \\
\hline & New: $Z_{\text {retention }}\left(\Phi_{\text {ep }}\right)(\mathrm{kg})=0.0526 \times 1 \times 265 \times 0.95 \times 0.005 / 100=0.0066 \mathrm{~kg}$ \\
\hline & Calculated impacts \\
\hline & Total \\
\hline \multirow[t]{3}{*}{ Equation PO-8 } & $\mathrm{N}_{\text {excreted }}\left(\Phi_{\mathrm{ep}}\right)(\mathrm{kg})=\Sigma\left(\mathrm{FI}_{\mathrm{Ph}} \times \% \mathrm{CP}_{\mathrm{Ph}} / 100\right) / 6.25 \times\left(\left(0.0182 \times \mathrm{EW} \times \Phi_{\mathrm{ep}}\right) \times \mathrm{ENb}\right)$ \\
\hline & Initial: $\mathrm{N}_{\text {excreted }}\left(\Phi_{\mathrm{ep}}\right)(\mathrm{kg})=26.3 \times 18.5 / 100 / 6.25 \times((0.0182 \times 52.6) \times 265 \times 0.95)=188 \mathrm{~kg}$ \\
\hline & New: $\mathrm{N}_{\text {excreted }}\left(\Phi_{\mathrm{ep}}\right)(\mathrm{kg})=26.3 \times 18.5 \times 0.954 / 100 / 6.25 \times((0.0182 \times 52.6) \times 265 \times 0.95)=179 \mathrm{~kg}$ \\
\hline \multirow[t]{3}{*}{ Equation FA-9 } & $\mathrm{P}_{\text {excreted }}\left(\Phi_{\mathrm{ep}}\right)(\mathrm{kg})=\mathrm{P}_{\text {intake }}-\mathrm{P}_{\text {retained }}\left(\Phi_{\mathrm{ep}}\right)$ \\
\hline & Initial: $P_{\text {excreted }}\left(\Phi_{\mathrm{ep}}\right)(\mathrm{kg})=0.1315-0.0697=0.0618 \mathrm{~kg}$ \\
\hline & New: $P_{\text {excreted }}\left(\Phi_{\text {ep }}\right)(\mathrm{kg})=0.0947-0.0662=0.0285 \mathrm{~kg}$ \\
\hline \multirow[t]{3}{*}{ Equation FA-10 } & $\mathrm{Cu}_{\text {excreted }}\left(\Phi_{\mathrm{ep}}\right)(\mathrm{kg})=\mathrm{Cu}_{\text {intake }}-\mathrm{Cu}_{\text {retained }}\left(\Phi_{\mathrm{ep}}\right)$ \\
\hline & Initial: $\mathrm{Cu}_{\text {excreted }}\left(\Phi_{\mathrm{ep}}\right)(\mathrm{kg})=0.00526-0.00279=0.00247 \mathrm{~kg}$ \\
\hline & New: $\mathrm{Cu}_{\text {excreted }}\left(\Phi_{\text {ep }}\right)(\mathrm{kg})=0.00526-0.00265=0.00261 \mathrm{~kg}$ \\
\hline \multirow[t]{3}{*}{ Equation FA-11 } & $\mathrm{Zn}_{\text {excreted }}\left(\Phi_{\text {ep }}\right)(\mathrm{kg})=\mathrm{Zn}_{\text {intake }}-\mathrm{Zn}_{\text {retained }}\left(\Phi_{\text {ep }}\right)$ \\
\hline & Initial: $\mathrm{Zn}_{\text {excreted }}\left(\Phi_{\mathrm{ep}}\right)(\mathrm{kg})=0.0132-0.0070=0.0062 \mathrm{~kg}$ \\
\hline & New: $Z_{n_{\text {excreted }}}\left(\Phi_{\text {ep }}\right)(\mathrm{kg})=0.0132-0.0066=0.0066 \mathrm{~kg}$ \\
\hline
\end{tabular}


Environmental performance of feed additives in livestock supply

\begin{tabular}{cc}
\hline Equation PO-13 & $\mathrm{N}_{2} \mathrm{O}_{\text {manure }}\left(\Phi_{\text {ep }}\right)(\mathrm{kg})=\mathrm{N}_{\text {excreted }}\left(\Phi_{\text {ep }}\right) \times \mathrm{EF}_{\mathrm{MMS}} \times 44 / 28$ \\
& Initial: $\mathrm{N}_{2} \mathrm{O}_{\text {manure }}\left(\Phi_{\mathrm{ep}}\right)(\mathrm{kg})=188 \times 0.005 \times 44 / 28=1.477 \mathrm{~kg}$ \\
$\mathrm{New}: \mathrm{N}_{2} \mathrm{O}_{\text {manure }}\left(\Phi_{\mathrm{ep}}\right)(\mathrm{kg})=179 \times 0.005 \times 44 / 28=1.406 \mathrm{~kg}$
\end{tabular}

Based on this sensitivity analysis, it appears that the reduction by 5 percent of the number of eggs produced leads to a total eradication of the effect on excreted nitrogen and a strong reduction of the excreted phosphorus.

\section{Conclusion}

Based on the analysis of the change (considering the change of formulation and the impact on the farm), the feed miller will be able to provide the egg brand owner with an evaluation of the potential effect of the formulation change.

\section{REFERENCES}

FAO. 2016a. Environmental performance of animal feeds supply chains: Guidelines for assessment. Livestock Environmental Assessment and Performance (LEAP) Partnership. Rome, FAO. (also available at www.fao.org/3/a-i6433e.pdf).

FAO.2016b. Environmentalperformance oflargeruminantsupplychains: Guidelinesforassessment. Livestock Environmental Assessment and Performance (LEAP) Partnership. Rome, FAO. (also available at www.fao.org/3/a-i6494e.pdf). 



\section{Contact information}

LEAP Partnership Secretariat

Food and Agriculture Organization of the United Nations

Viale delle Terme di Caracalla

00153 Rome, Italy

E-mail Livestock-Partnership@fao.org

http://www.fao.org/partnerships/leap

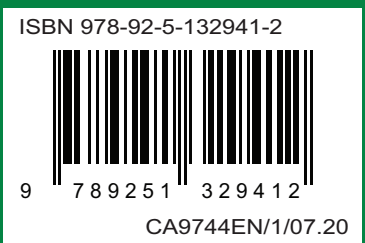

